AUTARQUIA ASSOCIADA À UNIVERSIDADE DE SÃO PAULO

ESTUDO DE ROTAS DE SÍNTESE E PROCESSAMENTO CERÂMICO DO COMPÓSITO NiO-YSZ PARA APLICAÇÃO COMO ANODO EM CÉLULAS A COMBUSTÍVEL DO TIPO ÓXIDO SÓLIDO

\author{
WALTER KENJI YOSHITO
}

Tese apresentada como parte dos requisitos para obtenção do Grau de Doutor em Ciências na Área de Tecnologia Nuclear - Materiais

Orientador:

Prof. Dr. José Octavio Armani Paschoal Co-Orientadora:

Prof ${ }^{a}$. Dra . Dolores Ribeiro Ricci Lazar

São Paulo

2011 
A men pai (In Memorian), minha mãe e irmãos. que sempre deram apoio 


\section{AGRADECIMENTOS}

Ao Instituto de Pesquisa Energéticas e Nucleares, pela oportunidade de realizar este trabalho.

Ao Dr. José Octavio Armani Paschoal, pela orientação, confiança, apoio, incentivo e amizade.

À Dra. Dolores Ribeiro Ricci Lazar, pela orientação, apoio, incentivos, e constantes contribuições no desenvolvimento do trabalho.

À banca examinadora, Dra. Emília Satoshi Miyamaru Seo, Dr. Jivaldo do Rosário Matos, Dra. Margarida Juri Saeki, Dr. Nelson Batista de Lima, e os suplentes Dra. Chieko Yamagata, Dr. Douglas Gouvea, Dra. Eliana Navarro S. Muccillo, Dr. Samuel Marcio Toffoli e Dr. Valter Ussui.

Ao Dr. Valter Ussui pela atenção, amizade, colaboração e apoio nas atividades.

A Dra. Chieko Yamagata pela amizade, colaboração e apoio na finalização da tese.

Um agradecimento especial aos amigos do Laboratório de Insumos: Bel. Sandra Maria da Cunha, Joana Domingos de Andrade e MSc Alexander Rodrigo Arakaki pela amizade e apoio nas execuções das atividades.

Ao amigo Dr. Hidetoshi Takiishi pela amizade, apoio e por tornar o ambiente de trabalho mais agradável.

A Dra. Emília Satoshi Miyamaru Seo pela amizade e por participar na etapa inicial deste trabalho.

Um agradecimento aos amigos: Chiba, Marcos, Reinaldo, João Batista, Ana Lucia, Beth, Genova, Edson, Nildemar, Celso, Glauson, Olandir, Rene, Marlene, Betinha e todos que de alguma maneira deram seu apoio e incentivo. Ao Laboratório de Análise Térmica (LATIG) do Instituto de Química da Universidade de São Paulo (USP), Dr. Jivaldo do Rosário Matos pelo apoio nas análises térmicas, amizade e incentivo.

Ao Laboratório do Departamento de Química - UNESP Botucatu, Dra. Margarida Juri Saeki por disponibilizar o laboratório e pela amizade.

Ao Laboratório de Difração de raios X, Dr. Nelson Batista de Lima e Rene Ramos de Oliveira pelas análises de difração de raios $\mathrm{X}$, amizade e apoio. 
Ao Laboratório de Reologia, Dra Sonia Regina Homem de Mello Castanho por disponibilizar o laboratório para análise de potencial zeta, pelo incentivo e amizade.

Ao Laboratório de Microscopia (Eletrônica de Varredura e Transmissão), Dra Ana Helena Almeida Bressiani, Nildemar Aparecido Messias Ferreira Celso Vieira de Morais, e Glauson Aparecido Machado pelas análises de microscopia eletrônica, amizade e constante apoio nas análises de imagem.

Ao Laboratório de Vidros e Compósitos, Dr. José Roberto Martinelli pela análise de tamanho de partículas e amizade.

Ao Laboratório de Corrosão, Dr. Lalgudi V. Ramanathan e Olandir V. Correa pelas análises térmicas.

Ao Laboratório de Caracterização Química, Dra Marycel E. B. Contrim.

Ao Laboratório de fluorescência de raios X, Dr. Marcos A. Scapin.

Ao Laboratório de Combustível Nuclear, Felipe B. Ferrufino e Jorge Clementino dos Santos pelas análises de densidade por picnometria de hélio.

Ao Msc Gilberto Hage Marcondes e Reinaldo Pereira da Costa pelas micrografias óticas.

Ao C.C.C.H, Dra. Eliana Aricó e Dr. Thomaz A. G. Restivo pela análise térmica e medida dilatométrica.

Aos meus familiares que deram apoio e incentivo necessário para 0 desenvolvimento deste trabalho. 


\title{
ESTUDO DE ROTAS DE SÍNTESE E DE PROCESSAMENTO CERÂMICO DO COMPÓSITO NiO-YSZ PARA APLICAÇÃO COMO ANODO EM CÉLULAS A COMBUSTÍVEL DO TIPO ÓXIDO SÓLIDO (SOFC) \\ WALTER KENJI YOSHITO
}

\begin{abstract}
RESUMO
Este estudo visa a definição de condições de síntese e processamento cerâmico que possibilitem a obtenção do componente anódico com características adequadas para a operação de uma SOFC (Solid Oxide Fuel Cell), ou seja, boa distribuição microestrutural do NiO na matriz de YSZ e porosidade cerca de $30 \%$ após redução de $\mathrm{NiO}$. As rotas de síntese selecionadas englobaram a coprecipitação em meio amoniacal, mistura mecânica dos pós e combustão a partir de sais de nitrato. As técnicas de caracterização de pós empregadas incluíram a difração de raios $\mathrm{X}$, microscopia eletrônica de varredura, microscopia eletrônica de transmissão, difração a laser, adsorção gasosa (BET) e picnometria de hélio. Os resultados obtidos indicaram que empregando-se a técnica de coprecipitação, a perda de $\mathrm{Ni}^{2+}$, na forma de complexo $\left[\mathrm{Ni}\left(\mathrm{NH}_{3}\right)_{n}\right]^{2+}$, pode ser minimizada pelo controle do $\mathrm{pH}$ em 9,3 , mantendo-se a concentração de $\mathrm{Ni}^{2+}$ na solução inicial em $0,1 \mathrm{M}$. No método de mistura mecânica a melhor condição de dispersão dos pós, sem a sedimentação diferencial, foi obtida para valores de potencial zeta em $\mathrm{pH} 8,0$, fixando-se a concentração de dispersante em 0,8\% em massa. Na síntese por combustão observou-se que para composições pobres em combustível, os produtos finais apresentaram-se amorfos e com alta área superficial $\left(120,2 \mathrm{~m}^{2} \cdot \mathrm{g}^{-1}\right)$. Para as composições ricas em combustível, uréia, os pós obtidos apresentaram-se cristalinos sendo que a intensidade das reflexões do padrão de DRX aumenta com o aumento do excesso de combustível, devido ao aumento da temperatura de reação. No estudo de sinterabilidade dos compactados preparados a partir de pós preparados pelos três métodos determinou-se a temperatura ao redor de $1300^{\circ} \mathrm{C}$ para máxima taxa de densificação e porosidade entre 6,0 e 14\%. Os resultados da redução em atmosfera de $\mathrm{H}_{2}$ dos compósitos confirmam que a cinética de reação ocorre em duas etapas, sendo que a primeira etapa com comportamento linear é controlada por reação química na superfície. Na segunda etapa a redução passa a ser controlada pela difusão do gás nos micros poros, gerados pela redução do $\mathrm{NiO}$, diminuindo a taxa de redução.
\end{abstract}




\section{STUDY OF SYNTHESIS ROUTES AND PROCESSING OF NIO-YSZ CERAMIC COMPOSITE FOR USE AS ANODE IN SOLID OXIDE FUEL CELL (SOFC)}

\section{WALTER KENJI YOSHITO}

\section{ABSTRACT}

This study aim the definition of synthesis and ceramic processing conditions of the anodic component suitable for operation of SOFC, i.e, homogeneous distribution of $\mathrm{NiO}$ in YSZ matrix and porosity after reduction above $30 \%$. The selected synthesis routes included the co-precipitation in ammonia media, mechanical mixing of powders and combustion reaction from nitrate salts. The characterization techniques of powders included the X-ray diffraction, scanning and transmission electron microscopy, laser diffraction, nitrogen gas adsorption technique (BET) and Helium pycnometry. The obtained results indicated that the loss of $\mathrm{Ni}^{2+}$ in co-precipitation process, due to the formation of complex $\left[\mathrm{Ni}\left(\mathrm{NH}_{3}\right)_{n}\right]^{2+}$, can be minimized by controlling the $\mathrm{pH}$ around 9.3, keeping the concentration of nickel cation in the solution to be precipitated around $0.1 \mathrm{M}$. In the mechanical mixing method the best condition of powder dispersion, without differential sedimentation, was obtained for zeta potential values at $\mathrm{pH}$ around 8.0 , fixing the dispersant concentration at $0.8 \%$. For the combustion synthesis it was observed that when stoichiometric and twofold stoichiometric urea was used, amorphous phase was formed and a higher surface area was attained in the final products. Employing the fuel-rich solution condition, crystallization of the powder was observed and the relative intensity of reflections of XRD patterns increased with excess of fuel, due to increasing the reaction temperature. Sinterability studies of pellets prepared from powder synthesized by the three routes described above showed the temperature around $1300 \cong \mathrm{C}$ for maximum rate densification and porosity between 6.0 and $14 \%$. Reduction results of the composites confirmed that the reduction kinetics occurs in two steps. The first one with a linear behavior and controlled by chemical reaction on the surface. The second reduction step is the reduction that is controlled by gas diffusion in micro pores, generated by reduction of nickel oxide, decreasing the rate of reduction. 


\section{SUMÁRIO}

Página

I INTRODUÇÃO

II OBJETIVOS DO TRABALHO 10

III ASPECTOS RELEVANTES DA LITERATURA 11

III.1 - Considerações gerais sobre as cerâmicas de zircônia estabilizada e os compósitos NiO-YSZ e Ni-YSZ 11

III.2 - Métodos de síntese do compósito NiO-YSZ 13

III.2.1 - A química do níquel 13

III.2.2 - Precipitação dos hidróxidos de Zr, Y e Ni 20

III.2.3 - Métodos de síntese do compósito NiO-YSZ pela técnica de mistura mecânica dos pós 21

III.2.4 - Métodos de síntese do compósito NiO-YSZ pela técnica de combustão 26

III.3 - Microestrutura das cerâmicas NiO-YSZ 29

III.3.1 - Cinética e mecanismo de sinterização 29

III.4 - Redução do NiO pelo hidrogênio 35

IV PROCEDIMENTO EXPERIMENTAL 40

IV.1 - Matérias - primas de partida $\quad 40$

IV.2 - Preparação de pós precursores $\quad 41$

IV.2.1 - Síntese dos pós $\quad 42$

IV.2.1.1 - Síntese por coprecipitação 42

IV.2.1.2 - Síntese por combustão $\quad 45$

IV.2.1.3 - Mistura de pós $\quad 47$

IV.3 - Caracterização dos pós $\quad 49$ 
IV.4 - Processamento cerâmico $\quad 50$

IV.4.1 - Estudo de sinterização $\quad 51$

IV.5 - Estudo da cinética de redução 51

IV.5.1- Cinética de redução dos pós 51

IV.5.2 - Cinética de redução do corpo cerâmico 52

IV.5.2.1 - Corpo cerâmico sem formador de poros 52

IV.5.2.2 - Corpo cerâmico com formador de poro 53

IV.5.2.2.1 - Amido de milho 53

IV.5.2.2.2 - Farinha de jatobá e negro de fumo 53

IV.6 - Caracterização dos produtos sinterizados e submetidos à redução com hidrogênio $\quad 54$

V RESULTADOS E DISCUSSÃO 55

V.1 - Rota de coprecipitação $\quad 56$

$\begin{array}{ll}\text { V.2 - Método da mistura de pós } & 67\end{array}$

$\begin{array}{ll}\text { V.3 - Síntese por combustão } & 77\end{array}$

V.4 - Estudo comparativo de processamento dos pós obtidos a partir da otimização dos métodos de sínteses adotados

V.4.1 - Estudo de sinterização 101

V.4.2 - Estudo de redução do NiO pelo hidrogênio 117

VI CONCLUSÕES 144

VII SUGESTÕES PARA TRABALHOS FUTUROS 146

VIII REFERÊNCIAS BIBLIOGRÁFICAS 147 


\section{LISTA DE TABELAS}

Página

Tabela 1 Dados termodinâmicos para o sistema $\mathrm{Ni}^{-} \mathrm{NH}_{3}-\mathrm{H}_{2} \mathrm{O}$

Tabela 2 Quantidade de gás liberado após a combustão completa do combustível

Tabela 3 Dados para cálculo do volume molar do óxido de níquel e níquel metálico

Tabela 4 Matérias primas empregadas na preparação do compósito NiO-YSZ

Tabela 5 Relação de amostras com as respectivas quantidades de combustível adicionado em excesso

Tabela 6 Relação de amostras submetidas à calcinação por 1hora em temperatura entre 700 e $1000^{\circ} \mathrm{C}$

Tabela 7 Rendimento da precipitação de níquel no compósito NiO-YSZ e composição química das amostras.

Tabela 8 Características físicas dos pós obtidos por coprecipitação, calcinados a $800{ }^{\circ} \mathrm{C}$ por um período de uma hora e submetidos à moagem em moinho de bolas

Tabela 9 Comparação dos valores de porosidade e densidade aparente entre as amostras não reduzida (CPOONR) e amostra reduzida (CPR1A)

Tabela 10 Características físicas dos pós obtidos por reação de combustão, em função da relação molar uréia/nitratos

Tabela 11 Análise elementar dos pós NiO-YSZ sem tratamento térmico, calcinado a $650^{\circ} \mathrm{C}$ e $700^{\circ} \mathrm{C}$

Tabela 12 Tamanho médio dos aglomerados, área de superfície especifica dos pós NiO-YSZ, sem calcinação e submetido à calcinação entre 700 e $1000{ }^{\circ} \mathrm{C}$

Tabela 13 Tamanho médio dos aglomerados, área de superfície especifica dos pós NiO-YSZ sem moagem: (CO 1), $(C O 1-800)$ e $(C O 3,75)$ e submetidos à moagem: (COM 1), (COM 1-800) e (COM 3,75) 
Tabela 14 Máxima taxa de retração e retração linear total para as amostras obtidas a partir de pós NiO-YSZ

Tabela 15 Valores de densidades e porosidade para as amostras obtidas a partir de pós NiO-YSZ sem moagem (CO), com moagem (COM), sem tratamento térmico (CO 1) e calcinados a $800{ }^{\circ} \mathrm{C}$ (CO 1-800) e com excesso de combustível (CO 3,75 e com 3,75).

Tabela 16 Máxima taxa de retração e retração linear total para as amostras obtidas a partir de pós NiO-YSZ sem tratamento térmico e calcinados a $800{ }^{\circ} \mathrm{C}(\mathrm{CO} 1-800)$ e $1000 \stackrel{\circ}{\mathrm{C}}(\mathrm{CO} 1-1000)$

Tabela 17 Valores de densidades para amostra não submetido à calcinação (CO 1) e calcinadas a $800{ }^{\circ} \mathrm{C}(\mathrm{CO} 1-800)$ e $1000{ }^{\circ} \mathrm{C}(\mathrm{C} 01-1000)$

Tabela 18 Densidades das amostras após a redução do óxido de níquel para níquel metálico

Tabela 19 Características físicas dos pós de 56\% NiO:YSZ obtidos pelas três rotas de síntese e moagem em moinho de alta energia por 6 horas

Tabela 20 Temperatura de máxima taxa de retração e retração linear total de amostras de 56\% NiO:YSZ obtidas pelas técnicas de coprecipitação, combustão e mistura de pós submetidas à diferentes razões de aquecimento $\left(5,10,15\right.$ e $\left.20 \stackrel{\circ}{ } \mathrm{C} \cdot \mathrm{min}^{-1}\right)$. Dados obtidos para amostras CO e MP (combustão e mistura de pós), na mesma condição de ensaio das amostras CP

Tabela 21 Dados de sinterização obtidos a partir das medidas realizadas em dilatômetro

Tabela 22 Dados obtidos da equação de Makipirtti-Meng para análise da cinética de sinterização para amostra obtida pelo método da coprecipitação 
Tabela 23 Dados obtidos da equação de Makipirtti-Meng para análise da cinética de sinterização para amostra obtida pelo método da combustão

Tabela 24 Dados obtidos da equação de Makipirtti-Meng para análise da cinética de sinterização para amostra obtida pelo método da mistura de pós

Tabela 25 Densidade a verde das amostras obtidas pelo método da combustão (CO), coprecipitação (CP) e mistura de pós $(\mathrm{MP})$, retração linear e a energia de ativação de sinterização

Tabela 26 Temperatura onde ocorre a máxima taxa de redução para diferentes razões de aquecimento $(5,10,15 \mathrm{e}$ $20{ }^{\circ} \mathrm{C} \cdot \mathrm{min}^{-1}$ ) e valores de taxa de redução obtida na região mais linear da curva

Tabela 27 Valores de densidades e porosidade das amostras cerâmicas de NiO-YSZ provenientes de pós sintetizados por coprecipitação, sinterizadas com a presença de formador de poros

Tabela 28 Densidades das amostras com formadores de poros (amido de milho) submetidos à redução em atmosfera de hidrogênio

Tabela 29 Densidades e porosidades das amostras com formadores de poros (farinha de jatobá) antes da redução

Tabela 30 Densidades e porosidades das amostras com formadores de poros (farinha de jatobá) após a redução

Tabela 31 Densidades e porosidades das amostras com formadores de poros (negro de fumo) antes da redução

Tabela 32 Densidades e porosidades das amostras com formadores de poros (negro de fumo) após a redução 


\section{LISTA DE FIGURAS}

Página

Figura 1 Diagrama de fases do sistema $\mathrm{ZrO}_{2}-\mathrm{Y}_{2} \mathrm{O}_{3} \quad 14$

Figura 2 Curva de solubilidade de $\mathrm{Ni}(\mathrm{OH})_{2}$ a $25{ }^{\circ} \mathrm{C} \quad 19$

Figura 3 Espectro visível da luz dos complexos $\left[\mathrm{Ni}\left(\mathrm{NH}_{3}\right)_{\mathrm{n}} \cdot\left(\mathrm{H}_{2} \mathrm{O}\right)_{6-\mathrm{n}}\right)(\mathrm{n}=0$ - 6) em função do $\mathrm{pH}$ de precipitação com amônia

Figura 4 Arranjo espacial dos íons que constituem a dupla camada elétrica de uma partícula carregada em um meio liquido

Figura 5 Diagrama esquemático do processo de síntese de NiO

Figura 6 Diagrama esquemático do processo de síntese por coprecipitação do compósito NiO-YSZ

Figura7 Diagrama esquemático do processo de síntese por combustão do compósito NIO-YSZ

Figura 8 Diagrama esquemático do processo de síntese por coprecipitação de YSZ

Figura 9 Evolução do pH (a) e concentração de níquel (b) na solução mãe, em função da concentração molar de hidróxido de amônio

Figura 10 Rendimento da precipitação de Ni em função do pH (a), e concentração deste cátion na solução precursora cujo $\mathrm{pH}$ foi fixado em 9,5 (b)

Figura 11 Variação na coloração das soluções contendo níquel em função da concentração de $\mathrm{NH}_{4} \mathrm{OH}$

Figura 12 Espectro de difração de raios $X$ da amostra $\beta-\mathrm{Ni}(\mathrm{OH})_{2}$

Figura 13 Curvas TG/DTG dos pós hidróxido seco otidos pela rota da coprecipitação obtidas com taxa de aquecimento de $10^{\circ}$ C. $\min ^{-1}$ e sob atmosfera dinâmica de ar comprimido 
Figura 14 Distribuição granulométrica dos pós NiO-YSZ obtidos após calcinação a $800{ }^{\circ} \mathrm{C}$ e moagem .

Figura 15 Espectro de difração de raios $X$ dos pós NiO 52\% em massa - YSZ obtidos por coprecipitação, calcinação a $800^{\circ} \mathrm{C}$ por uma hora e moagem em moinho de bolas

Figura 16 Micrografias obtidas por MEV (a) e MET (b) dos pós de $52 \%$ em massa NiO-YSZ obtidos por coprecipitação, calcinação a $800{ }^{\circ} \mathrm{C}$ por uma hora e moagem em moinho de bolas

Figura 17 Curvas TG (a) e DTG (b) de retração do compósito obtido pelo método de sintese por coprecipitação durante o aquecimento e processo de sinterização. A temperatura final da sinterização $1400{ }^{\circ} \mathrm{C}$

Figura 18 Micrografia (MEV) da superfície polida e tratada termicamente de amostra cerâmica de NiO-YSZ, conformada por prensagem uniaxial e sinterizada a $1500{ }^{\circ} \mathrm{C}$ por 1 hora, cujos pós de partida foram sintetizado por coprecipitação

Figura 19 Curvas TG/DTG e T obtidas a $20 \mathrm{C} / \mathrm{min}$ com $60 \mathrm{~min}$ a $900{ }^{\complement} \mathrm{C}$ e sob atmosfera de $\mathrm{N}_{2}\left(67 \mathrm{~mL} \cdot \mathrm{min}^{-1}\right)$ e $\mathrm{H}_{2}$ (33 $\mathrm{mL} \cdot \mathrm{min}^{-1}$ ) do corpo cerâmico obtido por coprecipitação

Figura20 Micrografia (MEV) da superfície polida e da amostra cerâmica de NiO-YSZ reduzida em atmosfera de $4 \% \mathrm{H}_{2}$ em balanço com argônio. Vazão de $100 \mathrm{~mL} \cdot \mathrm{min}^{-1}$

Figura 21 Potencial zeta de suspensões de $\mathrm{NiO}$ e YSZ, sem adição de aditivos, em função do $\mathrm{pH}$

Figura 22 Potencial zeta em função do pH de suspensões de $\mathrm{NiO}$ (a) de YSZ (b) 
Figura 23 Tensão de cisalhamento (a) e viscosidade (b) em função taxa de cisalhamento, de suspensões de NiO-YSZ, cujo pH foi ajustado na faixa de 8 a 10

Figura 24 Espectro de difração de raios $X$ da mistura de pós de $\mathrm{NiO}-\mathrm{YSZ}$

Figura 25 Micrografias (MEV) da mistura de pós de NiO-YSZ e (b) da superfície polida da amostra cerâmica de NiO-YSZ conformada por prensagem uniaxial e sinterizada a $1500 \stackrel{\circ}{\mathrm{C}}$ por 1 hora

Figura 26 Fração de $\mathrm{NiO}$ reduzido na cerâmica NiO-YSZ obtida por mistura de pós (a) e perda de massa em gramas (b) em função do tempo de redução em atmosfera de hidrogênio

Figura 27 Porosidade de cerâmica $\mathrm{NiO}$ (52\% em massa)/YSZ obtida por mistura de pós em função da fração de $\mathrm{NiO}$ reduzido

Figura 28 Micrografia ótica das seções transversais do compósito NiO -YSZ obtida por mistura de pós: sem (a), redução a $900 \stackrel{\circ}{\circ}$ por 15 minutos(b) e 60 minutos (c).

Figura 29 Micrografias MEV das superfícies polidas e tratadas termicamente das amostras cerâmicas NiO-YSZ obtidas por mistura de pós: sinterizadas a $1500^{\circ} \mathrm{C}$ por 1 hora (a), redução a $900^{\circ} \mathrm{C}$ por 1 hora (b) e 2 horas (c)

Figura 30 Difratogramas de raios $X$ dos compósitos NiO-YSZ obtido por mistura de pós, após sinterização (a), submetidos a redução a $900{ }^{\circ} \mathrm{C}$ por 05 minutos (b), 15 minutos (c), 30 minutos (d), 60 minutos (e) e 120 minutos (f) 
Figura 31 Difratogramas de raios $X$ dos pós NiO-YSZ produzidos por reação de combustão em função da relação molar uréia/nitrato $\Phi_{\mathrm{e}}$ em 1,0 (a); 0,65 (b); 0,57 (c); 0,55 (d) e $0,52(e)$

Figura 32 Distribuição granulométrica dos pós de NiO-YSZ moídos e produzidos por reação de combustão em função da relação molar uréia/nitrato, $\Phi_{\mathrm{e}}$ em 1,0 (a); 0,65 (b); 0,57 (c); 0,55 (d) e 0,52 (e)

Figura 33 Curvas TG/DTA obtidas e a $10^{\circ} \mathrm{C} \cdot \mathrm{min}^{-1}$ e sob atmosfera dinâmica de ar comprimido dos pós obtidos pelo método da combustão

Figura 34 Micrografias (MEV) dos pós obtidos por reação de combustão em função da relação molar uréia/nitratos, $\Phi_{\mathrm{e}}$ em 1,0 (a); 0,65 (b); 0,57 (c); 0,55 (d) e 0,52 (e)

Figura 35 Distribuição granulométrica dos pós de NiO-YSZ obtidos sem tratamento térmico (a) e após calcinação: $700{ }^{\circ} \mathrm{C}$ (b), $800{ }^{\circ} \mathrm{C}$ (c), $900{ }^{\circ} \mathrm{C}$ (d) e $1000^{\circ} \mathrm{C}$ ( e)

Figura 36 Difratogramas de raios-X dos pós NiO-YSZ obtidos sem tratamento térmico (a) e após calcinação: $700{ }^{\circ} \mathrm{C}$ (b), $800 \stackrel{\circ}{\mathrm{C}}(\mathrm{c}), 900{ }^{\circ} \mathrm{C}(\mathrm{d})$ e $1000{ }^{\circ} \mathrm{C}(\mathrm{e})$

Figura 37 Distribuição granulométrica dos pós sem moagem: sem calcinação CO 1 (a), submetido a calcinação $800^{\circ} \mathrm{C}$ CO 1-800 (b), obtidos com excesso de combustível $\mathrm{CO} 3,75$ (c) e submetidos a moagem: sem calcinação COM 1 (d), calcinado a $800^{\circ} \mathrm{C}$ COM 1-800 (e) e com excesso de combustível COM 3,75 (f)

Figura 38 Micrografias MEV dos pós: (CO 1) (a), $800{ }^{\circ} \mathrm{C}$ (CO 1-800) (b) e $(\mathrm{CO} 3,75)(\mathrm{c})$ 
Figura 39 Micrografias MEV dos pós submetidos a moagem: (COM 1) (a), (COM 1-800) calcinado a $800{ }^{\circ} \mathrm{C}$ (b) e $(\mathrm{COM} 3,75)(\mathrm{c})$

Figura 40 Curvas de retração linear (a), obtidas a $10{ }^{\circ} \mathrm{min}^{-1} \mathrm{em}$ fluxo de ar atmosférico para corpo cerâmico: $\operatorname{COM} 1$ (a), CO 1 (b), COM 1-800 (c), CO 1-800 (d), COM 3,75 e $\mathrm{CO} 3,75$ (f) e as respectivas derivadas das curvas de retração linear

Figura 41 Micrografias (MEV) das superfícies polidas e tratadas termicamente relativas às amostras cerâmicas NiO-YSZ em função da temperatura de calcinação dos pós: $\mathrm{CO} 1$ (a), $800{ }^{\circ} \mathrm{C}$ (c), CO 3,75 (e) e em função da moagem: $\operatorname{COM} 1$ (b), $\quad \operatorname{COM} 800 \stackrel{\circ}{\circ}$ (d) e COM 3,75 (f)

Figura 42 Curvas de retração linear (a), e de taxa de retração linear (b), obtidas a $10^{\circ} \mathrm{C} / \mathrm{min}$ em fluxo de ar atmos férico para os corpos cerâmicos: CO1 (a), CO 1-800 (b) e CO 1-1000 (c)

Figura 43 Micrografias (MEV) das superfícies polidas e tratadas termicamente relativas às amostras cerâmicas NiO-YSZ, em função da temperatura de calcinação dos pós: sem calcinação (CO 1) (a), calcinados a $800{ }^{\circ} \mathrm{C}$ (CO 1-800) (b) e calcinados a $1000^{\circ} \mathrm{C}$ (CO 1-1000) (c)

Figura 44 Micrografias (MEV) das superfícies polidas e tratadas termicamente relativas às amostras cerâmicas Ni-YSZ submetidas à redução em atmosfera redutora de $4 \% \mathrm{H}_{2}-96 \%$ Ar : COR 1 (a), COMR 1 (b), COR 1-800 (c), COMR 1-800 (d), CO 3,75 (e) e COMR 3,75 (f)

Figura 45 Micrografias obtidas por MEV $(a, b, c)$ dos pós com $56 \%$ em massa de NiO em 8,5YSZ obtido por coprecipitação (a), combustão (b) e mistura de pós (c)

Figura 46 Micrografias obtidas por MET (a,b,c) dos pós com $56 \%$ em massa de $\mathrm{NiO}$ em 8,5YSZ obtidos por coprecipitação (a), combustão (b) e mistura de pós (c) 
Figura 47 Retração linear em função da temperatura para amostras de $56 \%$ NiO:YSZ submetidas a diferentes razões de aquecimento $\left(5,10,15\right.$ e $\left.20 \stackrel{\circ}{\circ} \cdot m^{-1} n^{-1}\right)$ (a, c, e) e taxa de retração em função da temperatura de sinterização para amostras de $56 \% \mathrm{NiO}-\mathrm{YSZ}(\mathrm{b}, \mathrm{d}, \mathrm{f}$ )

Figura 48 Densidade relativa em função da temperatura de sinterização para amostras de NiO-YSZ cujos pós foram sintetizados por combustão, coprecipitação e mistura de pós

Figura 49 Taxa de densificação em função da temperatura para amostras das séries $\mathrm{CO}, \mathrm{CP}$ e MP, obtidas em razão de aquecimento constantes de 5, 1015 e $20 \stackrel{\circ}{\circ} \mathrm{C} \cdot \mathrm{min}^{-1} \mathrm{em}$ atmosfera dinâmica de ar sintético

Figura 50 Taxa de densificação em função da temperatura para amostras CO, CP e MP (a) e densidade relativa em função da temperatura (b) obtidas em razão de aquecimento constante de $10^{\circ} \mathrm{C} \cdot \mathrm{min}^{-1}$, em atmosfera dinâmica de ar sintético

Figura 51 Taxa de densificação em função da densidade relativa (a) e taxa de densificação em função da temperatura (b) para amostras $\mathrm{CO}, \mathrm{CP}$ e MP, obtidas em razão de aquecimento constante de $10 \stackrel{\circ}{\circ} \mathrm{C} \cdot \mathrm{min}^{-1}$, em atmosfera dinâmica de ar sintético

Figura 52 Curvas de densidade aparente (a) e de porosidade, em função da temperatura (b) para amostras $\mathrm{CO}, \mathrm{CP}$ e MP sinterizadas em forno caixa a uma razão de $10 \stackrel{\circ}{\circ} \mathrm{C} \cdot \mathrm{min}^{-1}$, sem isoterma

Figura 53 Determinação da energia de ativação usando a relação de Arrhenius em função da temperatura (1/T) para amostras de NiO-YSZ obtidas por CO (a), CP (b) e MP (c) submetido a ensaio de dilatometria 
Figura 54 Retração linear em função do tempo e temperatura (a) e curva de retração linear convertido em $\ln \{(\mathrm{dY} / \mathrm{dt}) /[\mathrm{Y} /(1-\mathrm{Y})]\}$ e $\ln [(1-\mathrm{Y}) / \mathrm{Y}]$ conforme equação de Makipirtti-Meng (b)

Figura 55 Constante de Arrhenius $\mathrm{k}(\mathrm{T})$ em função da temperatura $(1 / \mathrm{T})$ para amostra de NiO-YSZ submetidas a ensaios de dilatometria

Figura 56 Micrografias obtidas por MEV das superfícies de fratura de amostras cerâmicas de 56\% NiO:YSZ sintetizadas por coprecipitação (CP) e sinterizadas a $1200^{\circ} \mathrm{C}$ (a) e $1300{ }^{\circ} \mathrm{C}$ (b) e $1400{ }^{\circ} \mathrm{C}$ (c), adotando-se taxa de aquecimento de $10 \stackrel{\circ}{\circ} \mathrm{C} \cdot \mathrm{min}^{-1}$

Figura 57 Micrografias obtidas por MEV das superfícies polidas e submetidas a ataque térmico de amostras cerâmicas de 56\%NiO:YSZ sintetizadas por mistura de pós (a e d), combustão (b e e) e coprecipitação (c e f) e sinterizadas a $13000^{\circ} \mathrm{e}$ e $14000^{\circ} \mathrm{C}$

Figura 58 Perda de massa em função da temperatura para amostras obtidas pelos três métodos de síntese submetidas a uma vazão de $100 \mathrm{~mL} \cdot \mathrm{min}^{-1} \mathrm{em}$ atmosfera dinâmica de $20 \%$ de $\mathrm{H}_{2}$ em balanço com Ar e diferentes razão de aquecimentos $\left(5,10,15\right.$ e $\left.20 \stackrel{\circ}{\circ} \mathrm{C} \cdot \mathrm{min}^{-1}\right)$

Figura 59 Taxa de redução em função da temperatura para amostras obtidas pelos três métodos de síntese submetidas a uma vazão de $100 \mathrm{~mL} \cdot \mathrm{min}^{-1} \mathrm{em}$ atmosfera dinâmica de $20 \%$ de $\mathrm{H}_{2}$ em balanço com Ar e diferentes razão de aquecimentos $\left(5,10,15\right.$ e $\left.20 \stackrel{\circ}{\circ} \mathrm{C} \cdot \mathrm{min}^{-1}\right)$

Figura 60 Taxa de redução em função da temperatura para amostras obtidas pelos três métodos de síntese submetidas a uma vazão de $100 \mathrm{~mL} \cdot \mathrm{min}^{-1} \mathrm{em}$ atmosfera dinâmica de $20 \%$ de $\mathrm{H}_{2}$ em balanço com Ar e diferentes razões de aquecimentos $\left(5,10,15\right.$ e $\left.20 \stackrel{\circ}{\circ} \mathrm{C} \cdot \mathrm{min}^{-1}\right)$ 
Figura 61 Micrografia (MEV) dos pós calcinados a $1350 \stackrel{\circ}{\mathrm{C}}$ por 1 hora obtido pelo método de combustão (CO)

Figura 62 Micrografia (MEV) dos pós calcinados a $1350 \stackrel{\circ}{\circ} \mathrm{C}$ por 1 hora obtido pelo método de mistura de pós (MP)

Figura 63 Micrografia (MEV) dos pós calcinados a $1350 \stackrel{\circ}{\circ}$ por 1 hora obtido pelo método de coprecipitação (CP)

Figura 64 Micrografia (MEV) dos pós calcinados a $1350 \stackrel{\circ}{\circ} \mathrm{C}$ por 1 hora obtidos pelo método da coprecipitação $e$ mapeamento por EDS para identificação das fases no aglomerado

Figura 65 Micrografias (MEV) dos pós calcinados a $1350 \stackrel{\circ}{\circ}$ por 1 hora obtida pelo método da combustão e mapeamento por EDS para identificação das fases no aglomerado

Figura 66 Micrografias (MEV) dos pós calcinados a $1350 \stackrel{\circ}{\circ}$ por 1 hora obtida pelo método da mistura de pós e mapeamento por EDS para identificação das fases no aglomerado

Figura 67 Taxa de redução em função da temperatura para amostras obtidas pelos três métodos de síntese submetidas a uma vazão de $100 \mathrm{~mL} \cdot \mathrm{min}^{-1} \mathrm{em}$ atmosfera dinâmica de $20 \%$ de $\mathrm{H}_{2}$ em balanço com Ar e diferentes razão de aquecimentos $\left(5,10,15\right.$ e $\left.20 \stackrel{\circ}{\circ} \cdot \mathrm{min}^{-1}\right)$

Figura 68 Curvas de perda de massa de amostra cerâmica NiO-YSZ obtidas em forno tubular a partir de pós sintetizados pelas técnicas (MP), (CP) e (CO), em função do tempo de redução em atmosfera dinâmica de $4 \% \mathrm{H}_{2}$ em balanço com Ar e vazão de $100 \mathrm{~mL} \cdot \mathrm{min}^{-1}$

Figura 69 Curvas de porosidade em função do tempo para amostras $\mathrm{CO}, \mathrm{CP}$ e MP, submetidas à redução em isoterma de $900^{\circ} \mathrm{C}$ por período entre 05 e 120 minutos

Figura 70 Micrografias MEV dos formadores de poros: amido de milho (a), farinha de jatobá (b) e negro de fumo (c). 
Figura 71 Micrografias MEV das superfícies polidas e tratadas termicamente das amostras cerâmicas NiO-YSZ com formador de poros de amido de milho (a), farinha de jatobá (b) e negro de fumo (c).

Figura 72 Perda de massa (a) e taxa de redução em função da temperatura (b) para amostras com 10, 15 e 20\% de amido de milho e Fração de $\mathrm{NiO}$ reduzido em função do tempo

Figura 73 Valor de densidade aparente (a) e de porosidade em função da temperatura (b) para amostras $\mathrm{CO}, \mathrm{CP}$ e MP reduzidas em forno tipo caixa a $900^{\circ} \mathrm{C}$ sob atmosfera dinâmica de $\mathrm{H}_{2}$

Figura 74 Micrografia (MEV) da superfície de fratura das amostras cerâmicas com formadores de poros de jatobá obtidas pelos três métodos(mistura mecânica de pós (a), combustão (b) e coprecipitação (c)) por prensagem uniaxial e sinterização a $1350^{\circ} \mathrm{C}$ por 1 hora

Figura 75 Fração de $\mathrm{NiO}$ reduzido em função do tempo nas amostras cerâmicas obtidas pelos métodos de combustão (CO), coprecipitação (CP) e mistura de pós (MP) com formador de poros de negro de fumo

Figura 76 Micrografia (MEV) da superfície de fratura das amostras cerâmicas com formadores de poros de negro de fumo obtidas pelos três métodos (mistura mecânica de pós (a), combustão (b) e coprecipitação (c)) por prensagem uniaxial e sinterização a $1350{ }^{\circ} \mathrm{C}$ por 1 hora 


\section{LISTA DE SIMBOLOS}

\begin{tabular}{|c|c|}
\hline $\mathrm{a}_{\mathrm{NH}_{4}^{+}}^{+}$ & Atividade do íon amônio \\
\hline $\mathrm{a}_{\mathrm{OH}^{-}}$ & Atividade do íon $\mathrm{OH}^{-}$ \\
\hline $\mathrm{a}_{\mathrm{NH}_{3}^{+}}$ & Atividade da espécie $\mathrm{NH}_{3}$ \\
\hline $\mathrm{a}_{\mathrm{NH}_{4} \mathrm{OH}}$ & Atividade da espécie $\mathrm{NH}_{4} \mathrm{OH}$ \\
\hline $\mathrm{K}_{\mathrm{ps}}$ & Constante de produto de solubilidade \\
\hline $\mathrm{K}_{\mathrm{b}}$ & Constante de equilíbrio da reação de ionização da base $\mathrm{NH}_{3}$ \\
\hline$\eta$ & Fração de hidróxido precitado \\
\hline$\left[\mathrm{Ni}^{2+}\right]_{\mathrm{T}}$ & Concentração de $\mathrm{Ni}^{2+}$ em solução \\
\hline $\mathrm{Eh}^{0}$ & Potencial padrão de redução \\
\hline $\mathrm{K}_{\mathrm{w}}$ & Constante de equilíbrio da água \\
\hline $\mathrm{K}_{\mathrm{N}}$ & Constante de equilíbrio de formação dos íons amônia \\
\hline B & Constante de equilíbrio para formação dos complexos de níquel \\
\hline $\mathrm{V}_{\mathrm{A}}$ & Força de van der Waals \\
\hline $\mathrm{V}_{\mathrm{T}}$ & Força total \\
\hline$V_{R}$ & Força eletrostática, estérica e outras interações \\
\hline$\zeta$ & Potencial zeta \\
\hline$\Phi_{\mathrm{e}}$ & Coeficiente estequiométrico dos elementos \\
\hline$\Delta \mathrm{G}_{\mathrm{T}}$ & Variação de energia livre total do sistema \\
\hline$\Delta \mathrm{G}_{\mathrm{v}}$ & Variação de energia livre associadas ao volume \\
\hline$\Delta \mathrm{G}_{\mathrm{b}}$ & Variação de energia livre associada ao contorno de grão \\
\hline$\Delta \mathrm{G}_{\mathrm{s}}$ & Variação de energia livre associada a área de superfície \\
\hline$\gamma_{C G}$ & Energia do contorno de grão \\
\hline$\gamma_{s v}$ & Energia superficial da interface sólido/vapor \\
\hline
\end{tabular}


$\phi \quad$ Ângulo diédrico

L $\quad$ Comprimento da amostra

$\gamma \quad$ Energia superficial $\left(\mathrm{J} . \mathrm{m}^{-2}\right)$

$\Omega \quad$ Volume atômico $\left(\mathrm{m}^{3}\right)$

$\delta \quad$ Espessura do contorno de grão

$\Gamma_{\mathrm{b}} \quad$ Fator de escala de difusão por contorno de grão

$\Gamma_{\mathrm{v}} \quad$ Fator de escala de difusão por volume

G Tamanho médio dos grãos

k Constante de Boltzmann $\left(1,38066 \times 10^{-23} \mathrm{~J}^{-K^{-1}}\right)$

$\mathrm{T} \quad$ Temperatura absoluta $(\mathrm{K})$

$D_{b} \quad$ Coeficiente de difusão por contorno de grão $\left(\mathrm{m}^{2} \cdot \mathrm{s}^{-1}\right)$

$D_{v} \quad$ Coeficiente de difusão por volume $\left(\mathrm{m}^{2} \cdot \mathrm{s}^{-1}\right)$

$\Delta \mathrm{L} / \mathrm{L}_{0} \quad$ Variação da retração linear

n Parâmetro que define o mecanismo de difusão

A Coeficiente pré-exponencial da relação de Ahrrenius $\left(\mathrm{s}^{-1}\right)$

Q $\quad$ Energia de ativação em $\left(\mathrm{J} \cdot \mathrm{mol}^{-1}\right)$

$\mathrm{R} \quad$ Constante dos gases $\left(8,314 \mathrm{~J} \cdot \mathrm{mol}^{-1} \mathrm{~K}^{-1}\right)$

$\Delta \mathrm{V} \quad$ Variação molar entre o volume do níquel metálico e do óxido de níquel

$\mathrm{V}_{\mathrm{NiO}} \quad$ Volume molar de óxido de níquel

$\mathrm{V}_{\mathrm{Ni}} \quad$ Volume molar de níquel

P Porosidade

$\mathrm{P}_{0} \quad$ Porosidade inicial

$\rho_{0} \quad$ Densidade inicial $\left(\mathrm{g} . \mathrm{cm}^{-3}\right)$

$\rho_{\mathrm{Ni}} \quad$ Densidade teórica do níquel $\left(\mathrm{g} \cdot \mathrm{cm}^{-3}\right)$ 
$\rho_{\mathrm{NiO}} \quad$ Densidade teórica do óxido de níquel $\left(\mathrm{g}_{\mathrm{cm}} \mathrm{cm}^{-3}\right)$

$m_{N i O}^{0} \quad$ Massa fracional inicial de $\mathrm{NiO}$

mo Massa molecular de $\mathrm{O}_{2}$ (u.m.a.)

$\mathrm{m}_{\mathrm{NiO}} \quad$ Massa molecular $\mathrm{NiO}$ (u.m.a.)

R Fração de $\mathrm{NiO}$ reduzido

$\mathrm{C}_{\mathrm{NiO}} \quad$ Porcentagem em peso de NiO no compósito NiO-YSZ

$\alpha \quad$ Taxa de aquecimento $\left(\mathrm{K} \cdot \mathrm{min}^{-1}\right)$

$\mathrm{T}_{\mathrm{m}} \quad$ Temperatura para a máxima taxa de redução $(\mathrm{K})$

$\mathrm{E}_{\mathrm{a}} \quad$ Energia de ativação (J.mol $\left.{ }^{-1}\right)$

$\mathrm{k}_{0} \quad$ Fator pré-exponencial na equação de Arrhenius $\left(\mathrm{min}^{-1}\right)$

$\rho \quad$ Densidade da amostra $\left(\mathrm{g} \cdot \mathrm{cm}^{-3}\right)$

Págua Densidade da água $\left(\mathrm{g}_{\mathrm{cm}} \mathrm{cm}^{-3}\right)$

$\mathrm{m}_{\mathrm{s}} \quad$ Massa seca $(\mathrm{g})$

$\mathrm{m}_{\mathrm{u}} \quad$ Massa úmida $(\mathrm{g})$

$\mathrm{m}_{\mathrm{i}} \quad$ Massa imersa $(\mathrm{g})$

$\rho_{\mathrm{s}} \quad$ Densidade da amostra $\left(\mathrm{g} \cdot \mathrm{cm}^{-3}\right)$

PYsZ Densidade teórica do YSZ $\left(\mathrm{g}_{\mathrm{cm}} \mathrm{cm}^{-3}\right)$

$\mathrm{V}_{\mathrm{NiO}} \quad$ Volume fracional de $\mathrm{NiO}$

VYSZ Volume fracional de YSZ

$\rho(\mathrm{T}) \quad$ Densidade da amostra no tempo $\mathrm{T}\left(\mathrm{g} \cdot \mathrm{cm}^{-3}\right)$

$\mathrm{L}_{\mathrm{f}} \quad$ Comprimento final $(\mathrm{cm})$

$\mathrm{L}(\mathrm{T}) \quad$ Comprimento para a temperatura correspondente $(\mathrm{cm})$

$\rho_{\mathrm{f}} \quad$ Densidade final obtida pelo método de Archimedes 


\section{LISTA DE SIGLAS}

SOFC Solid Oxide Fuel Cell - Célula a combustível de óxido sólido

PEMFC Polymer Membrane Fuel Cell - Célula a combustível de membrana polimérica

AFC Alkaline Fuel Cell - Célula a combustível alcalina

PAFC Phosphoric Acid Fuel Cell - Célula a combustível de ácido fosfórico

MCFC Molten Carbonate Fuel Cell - Célula a combustível de carbonato fundido

YSZ

Yttria Stabilized Zirconia - Zircônia estabilizada com ítria

$\mathrm{Ni}$ - YSZ Níquel - Zircônia estabilizada com ítria

TPB Three Phase Boundary - Fase tríplice reacional

TPR Temperature Programmed Reduction

Temperatura programada de redução

PMAA-NH ${ }_{3}$ Polimetacrilato de amônio

MEV Microscopia eletrônica de varredura

SHS Self Propagating High Temperature Synthesis - Combustão auto-sustentada a alta temperatura

LCS Low Temperature Combustion Synthesis - Combustão a baixa temperatura

SCS Solution Combustion Synthesis - Combustão a partir de soluções

SID Stepwise Isothermal Dilatometry - Método quase-isotérmico por passo

BET Brunauer, Emmett e Teller - Método de determinação de área de superfície especifica

TG Termogravimetria

DTG Derivada da curva TG 
DTA Análise Térmica Diferencial

MET Microscopia eletrônica de transmissão

ICP - AES Técnica de espectrometria de emissão atômica com fonte plasma de argônio induzido

EDS Espectrômetro de dispersão de energia 


\section{LISTA DE CODIGO DAS AMOSTRAS}

\begin{tabular}{|c|c|c|}
\hline Amostra & Método & Condições \\
\hline CPOONR & Coprecipitação & Amostra não reduzida \\
\hline PR1A & Coprecipitação & Amostra reduzida \\
\hline CONYZ & Combustão & $\begin{array}{l}\text { Relação estequiométrica entre sal de } \\
\text { nitrato e combustível }\end{array}$ \\
\hline CONYZ - 1,0 & Combustão & $100 \%$ de excesso de combustível \\
\hline CONYZ - 1,5 & Combustão & $150 \%$ de excesso de combustível \\
\hline CONYZ - 1,75 & Combustão & $175 \%$ de excesso de combustível \\
\hline CONYZ - 2,0 & Combustão & $200 \%$ de excesso de combustível \\
\hline $\mathrm{CO} 1$ & Combustão & $\begin{array}{l}\text { Relação estequiométrica entre sal de } \\
\text { nitrato e combustível, não submetido à } \\
\text { calcinação }\end{array}$ \\
\hline CO 1-650 & Combustão & $\begin{array}{l}\text { Relação estequiométrica entre sal de } \\
\text { nitrato e combustível e calcinado a } \\
650 \text { C }\end{array}$ \\
\hline CO 1-700 & Combustão & $\begin{array}{l}\text { Relação estequiométrica entre sal de } \\
\text { nitrato e combustível e calcinado a } \\
700 \text { C }\end{array}$ \\
\hline CO 1-800 & Combustão & $\begin{array}{l}\text { Relação estequiométrica entre sal de } \\
\text { nitrato e combustível e calcinado a } \\
800 \text { C }\end{array}$ \\
\hline CO 1-900 & Combustão & $\begin{array}{l}\text { Relação estequiométrica entre sal de } \\
\text { nitrato e combustível e calcinado a } \\
900 \text { C }\end{array}$ \\
\hline CO 1-1000 & Combustão & $\begin{array}{l}\text { Relação estequiométrica entre sal de } \\
\text { nitrato e combustível e calcinado a } \\
1000^{\circ} \text {. }\end{array}$ \\
\hline
\end{tabular}


$\operatorname{co} 3,75$

COM 1

COM 1-800

$\operatorname{COM} 3,75$

COR 1

COR $1-800$

COR 3,75

COMR 1

COMR 1-800

COMR 3,75

$\mathrm{CO}$

$\mathrm{CP}$
Combustão Excesso de $175 \%$ de combustível e não calcinado

Combustão Relação estequiométrica entre sal de nitrato e combustível, submetido a moagem e não calcinado

Combustão Relação estequiométrica entre sal de nitrato e combustível, submetido a moagem e calcinado a $800^{\circ} \mathrm{C}$

Combustão Excesso de $175 \%$ de combustível, submetido à moagem e sem calcinação

Combustão Relação estequiométrica entre sal de nitrato e combustível, não submetido a calcinação e reduzido

Combustão Relação estequiométrica entre sal de nitrato e combustível, calcinado a $800{ }^{\circ} \mathrm{C}$ e submetido à redução

Combustão

Excesso de $175 \%$ de combustível, submetido à moagem, não calcinado e reduzido

Combustão Relação estequiométrica entre sal de nitrato e combustível, submetido a moagem, sem calcinação e reduzido

Combustão Relação estequiométrica entre sal de nitrato e combustível submetido à moagem, calcinado a $8000^{\circ} \mathrm{C}$ e reduzido Combustão Excesso de $175 \%$ de combustível, submetido à moagem, não calcinado e reduzido

Combustão Excesso de $150 \%$ de combustível, submetido à moagem em moinho de alta energia e sem calcinação

Coprecipitação Submetido à moagem em moinho de alta energia e calcinado a $800^{\circ} \mathrm{C}$ 
MP Mistura de pós Submetido à moagem em moinho de alta energia e calcinado a $800^{\circ} \mathrm{C}$

CP 5 Coprecipitação Amostra com $5 \%$ de formador de poros

CP 10 Coprecipitação Amostra com 10\% de formador de poros

CP 15 Coprecipitação Amostra com 15\% de formador de poros

CP 20 Coprecipitação Amostra com $20 \%$ de formador de poros

CO 10 Combustão Amostra com 10\% de formador de poros

CO 15 Combustão Amostra com 15\% de formador de poros

CO 20 Combustão Amostra com 20\% de formador de poros

MP 5 Mistura de pós Amostra com $5 \%$ de formador de poros

MP10 Mistura de pós Amostra com 10\% de formador de poros

MP 15 Mistura de pós Amostra com 15\% de formador de poros

MP 20 Mistura de pós Amostra com 20\% de formador de poros 


\section{I - INTRODUÇÃO}

O aumento da população mundial, a globalização da economia, o excessivo consumo de bens materiais e o impacto ambiental e social causados pela enorme dependência de fontes não renováveis de energia têm gerado níveis alarmantes de poluentes. $O$ uso de matriz energética com base nos combustíveis fósseis acarreta na emissão de grandes quantidades de $\mathrm{CO}_{2}$ na atmosfera, provocando o efeito estufa. Diante deste cenário, a busca por um desenvolvimento sustentável e consumo consciente passa a ser um grande desafio político, tecnológico e social. Neste sentido, a prioridade do setor energético é o uso de novas fontes alternativas em substituição ao petróleo e ao mesmo tempo o desenvolvimento de sistemas conversores de energia mais eficientes [1].

A tecnologia de células a combustível surge como uma excelente alternativa devido à disponibilidade da fonte energética constituída, neste caso, por $\mathrm{H}_{2}$ extraído de matrizes energéticas renováveis tais como gás natural, carvão, biomassa, metanol, etanol e hidrocarbonetos em geral. A importância desta tecnologia deve-se também à alta eficiência na conversão da energia química em energia elétrica, pois o desempenho na conversão não está sujeito à limitação como em uma maquina térmica (ciclo de Carnot). Este ciclo permite calcular o rendimento dessa máquina térmica considerando que o sistema recebe calor de uma fonte quente a uma dada temperatura, converte parte dele em trabalho e restitui ao ambiente a parte remanescente de calor não utilizado. Considerando que a fonte quente corresponde ao calor liberado pelas reações de combustão do combustível (entalpia) e que desse calor somente a parte referente à entalpia não é passível de transformação pela célula a combustível em energia elétrica, a energia livre total da reação de combustão pode ser convertida em energia elétrica. Outras vantagens das células a combustível incluem: possibilidade de construção modular e ampliação da capacidade instalada em um curto espaço de tempo, evitando com isso o superdimensionamento do sistema; mínimas restrições quanto à sua localização devido ao seu pequeno tamanho; operação silenciosa e ausência de vibração; compatibilidade ambiental, pois o índice de emissão de poluentes é baixo; e possibilidade de co-operação com outros sistema que usam fontes 
renováveis ou inesgotáveis tais como energia eólica, solar e biomassa para produção de hidrogênio.

O primeiro relato sobre os princípios de funcionamento de uma célula a combustível foi descrito por Sir William Grove em 1839, baseando-se na reversibilidade termodinâmica da eletrólise [2]. Em 1899, Nernst descobriu o eletrólito de óxido sólido ao usar a zircônia estabilizada para fazer filamento elétrico [3]. Foi ele também o primeiro a descrever a zircônia como condutor de íon oxigênio. Em 1937 Baur e Preis realizam a primeira operação de uma célula a combustível a $1000^{\circ} \mathrm{C}$, utilizando eletrólitos de zircônia-ítria [4]. Devido à alta temperatura de operação dessa célula e à condição redutora do gás combustível surgiram inúmeros problemas com os materiais, fato este que efetivamente provocou um grande atraso no desenvolvimento desta tecnologia. A partir de 1960, as pesquisas com células a combustível tiveram um período de intensa atividade devido ao sucesso obtido no programa espacial Apollo. Embora ainda hoje elas sejam utilizadas em naves espaciais, naquele programa foram desenvolvidas as células a combustível alcalinas, que têm como principais vantagens a baixa temperatura de operação (80 ${ }^{\circ} \mathrm{C}$ ), baixo custo dos materiais e alta densidade de potência (ao redor de $10 \mathrm{~kW}$ ). Contudo, estas células apresentam desvantagens de seu eletrólito ser facilmente envenenado pelo $\mathrm{CO}$ reduzindo a vida útil do sistema [5]. Neste mesmo período, com o avanço na preparação e produção de materiais cerâmicos, surge novamente 0 interesse na tecnologia de células a combustível de óxidos sólidos (SOFC - Solid Oxide Fuel Cell). No início da década de 80 os órgãos governamentais dos Estados Unidos, Japão e Canadá aumentaram significativamente os recursos financeiros para pesquisa e desenvolvimento em células a combustível visando aplicação em meio de transporte e sistemas estacionários de geração de energia elétrica [2,5,6].

Atualmente, os principais tipos de células a combustível que tem despertado um grande interesse dos pesquisadores são: célula a combustível de membrana polimérica (PEMFC - Polymer Electrolyte Membrane Fuel Cell), célula a combustível alcalina (AFC - Alkaline Fuel Cell), célula a combustível de ácido fosfórico (PAFC - Phosphoric Acid Fuel Cell), célula a combustível de carbonato fundido (MCFC - Molten Carbonate Fuel Cell) e célula a combustível 
de óxido sólido (SOFC - Solid Oxide Fuel Cell). Estas células são classificadas de acordo com o tipo de eletrólito utilizado e sua temperatura de [7 - 9].

Nas células a combustível de baixa temperatura (PEFC e AFC) a reforma do combustível (reação que transforma o combustível em uma mistura rica em hidrogênio) não é realizada no seu interior. Estas células são adequadas para substituir as baterias convencionais usadas em telefones celulares, notebooks, câmeras digitais e equipamentos portáteis em geral, devido à baixa potência requerida e temperatura de operação. Entre as principais vantagens das células a combustível deste tipo em relação à bateria convencional estão: maior densidade de potência, menor tamanho e peso e vida útil mais longa. Em particular, a célula a combustível de membrana polimérica é a mais indicada para aplicação em veículos automotores devido à alta densidade de potência, eficiência, baixa emissão de poluentes, necessidade de menor tempo de aquecimento em relação à célula a combustível de alta temperatura, e menor problema com o ciclo térmico (aquecimento/resfriamento).

As células de ácido fosfórico (PAFC) foram as primeiras a serem comercializadas para aplicação em sistema estacionário. Sua temperatura de operação, ao redor de $200 \stackrel{\circ}{\circ}$, faz com que sejam atrativas para operação com sistema de co-geração de energia. O hidrogênio usado como combustível é produzido em um reformador externo.

As células de carbonato fundido (MCFC) operam em temperaturas na faixa de 600 - $700{ }^{\circ} \mathrm{C}$. Esta alta temperatura de operação permite que $\mathrm{O}$ combustível seja reformado no interior da célula e a tecnologia teve seu auge de desenvolvimento na década de 90. As células de óxido sólido (SOFC) também operam a alta temperatura $(700-1000 \stackrel{\circ}{\circ})$ e a reforma do combustível pode ser feita em seu interior. O combustível a ser utilizado pode ser também uma mistura gasosa de $\mathrm{H}_{2}, \mathrm{CO}$ e $\mathrm{CO}_{2}$, que é produzido a partir da reforma dos hidrocarbonetos tais como gás natural, metanol, etanol, gaseficação de carvão entre outros, sem prévia purificação [10].

As células a combustível de alta temperatura (MCFC e SOFC) estão sendo desenvolvidas para sistemas estacionários de geração de energia, em função da alta eficiência na conversão, que está entre 40 - 55\%, com a atual 
tecnologia podendo atingir uma eficiência de aproximadamente $80 \%$, quando integradas a sistemas de co-geração, onde o calor liberado durante o processo é aproveitado, por exemplo, para movimentar turbina [11]. Outras vantagens destas células incluem: operação silenciosa, baixa emissão de poluentes, flexibilidade no uso de combustível e a construção modular, permitindo que sejam construídas unidades descentralizadas, com capacidade de alguns kW a MW, em áreas residenciais e localidades isoladas [12]. Entre as células que operam a alta temperatura, a de carbonato fundido (MCFC) tem 0 inconveniente de utilizar como eletrólito líquido, uma mistura de sais fundidos de carbonato alcalino, que é altamente corrosiva. Ao contrário da MCFC, a célula a combustível de óxido sólido, que é considerada a alternativa ideal para sistema de geração de eletricidade, pois não utiliza eletrólito líquido (todos os seus componentes são cerâmicos).

A célula do tipo SOFC difere de outras células em alguns aspectos. Por serem constituídas de componentes sólidos, é viabilizada a fabricação dos componentes em camadas muito finas e sem restrição quanto à configuração. O uso de materiais cerâmicos também elimina problemas de corrosão de materiais e gerenciamento de eletrólito. Outro aspecto benéfico refere-se à alta faixa de temperatura de operação permitindo uma rápida cinética de reação e a liberação de uma grande quantidade de calor como subproduto, que pode ser combinado com um sistema de co-geração de energia e calor. Esta alta temperatura permite uma maior tolerância do tipo de combustível e também a reforma interna deste risco de contaminação do catalisador. Por outro lado, uma série de exigências deve ser atendida quanto aos materiais a serem empregados na sua fabricação. Todos os materiais devem ter coeficientes de expansão térmica compatíveis, não deve ocorrer à interação química entre componentes vizinhos e devem apresentar mudança de estrutura nas condições de operação [13-15].

O princípio de funcionamento de uma célula a combustível de óxido sólido é baseada nas reações eletroquímicas que converte a energia química do combustível diretamente em energia elétrica. As reações ocorrem devido à diferença no potencial químico de oxigênio entre os eletrodos (anodo e catodo), no caso do eletrólito ser condutor de íons oxigênio. Os íons oxigênio formados 
no catodo migram através do eletrólito para o anodo e são consumidos pela oxidação do combustível.

Basicamente, uma unidade de célula a combustível é constituída de dois eletrodos porosos (anodo e catodo) separados por um eletrólito sólido condutor de íons oxigênio [16]. Adjacentes aos eletrodos têm-se o interconector que serve de coletor de corrente.

As reações eletroquímicas que ocorrem nos eletrodos são:

No catodo:

$$
1 / 2 \mathrm{O}_{2(\mathrm{~g})}+2 \mathrm{e}^{-} \rightarrow \mathrm{O}^{2-}
$$

No anodo:

$$
\mathrm{H}_{2(\mathrm{~g})}+\mathrm{O}_{(\mathrm{s})}^{2-} \rightarrow \mathrm{H}_{2} \mathrm{O}_{(\mathrm{g})}+2 \mathrm{e}^{-}
$$

Para que a cinética nos eletrodos seja rápida, eles devem promover a difusão dos reagentes e produtos gasosos, ser um bom condutor de íons oxigênio e de elétrons.

A combinação entre metal e cerâmica com diferentes propriedades possibilita o desenvolvimento e fabricação de materiais com estrutura adequada para o anodo de célula a combustível, sensores de gases e como suporte catalítico. Em termos de suas propriedades mecânicas, físico-químicas e eletromagnéticas, a cerâmica geralmente apresenta um alto ponto de fusão, baixa resistência mecânica e também baixa condutividade elétrica e não apresenta propriedade magnética. Ao contrário, os metais apresentam boa condutividade elétrica, temperatura de fusão intermediaria e sob tensão apresentam deformação plástica.

Os metais de transição são os melhores candidatos para serem utilizados como um dos componentes do anodo na SOFC devido a sua alta atividade catalítica e alta estabilidade em atmosfera redutora. Entre os metais, o níquel aparece como melhor candidato em função do custo, estabilidade química, volatilidade e atividade catalítica. Contudo, devido à diferença de coeficiente térmico entre o metal e o eletrólito cerâmico e à necessidade de uma fase condutora de íons oxigênio, o metal puro não pode ser utilizado como 
material anódico. Para contornar estes problemas é adicionado ao níquel material do eletrólito [17].

O compósito Ni-YSZ (níquel - zircônia estabilizada com ítria) é o material mais utilizado na fabricação do anodo da SOFC devido à alta atividade catalítica do níquel para oxidação do hidrogênio. Os eletrodos (catodo e anodo) devem preencher os seguintes requisitos: ter alta condutividade eletrônica, porosidade suficiente para difusão dos gases para zona de reação, ter alta atividade catalítica para redução do oxidante no catodo e oxidação do combustível no anodo, não reagir com o eletrólito e interconector e ter coeficiente de expansão térmica compatível com os componentes adjacentes $[6,18-20]$.

Atualmente é consenso entre pesquisadores e fabricantes que a diminuição da temperatura de operação é o principal fator para baixar o custo da célula, pois permite o uso de uma variedade maior de materiais. Em temperatura abaixo de $800{ }^{\circ} \mathrm{C}$ o processo de sinterização dos eletrodos é minimizado como a difusão interfacial entre o eletrodo e eletrólito. Assim, além de abaixar os custos, há um aumento na sua vida útil [21, 22].

Para minimizar a perda ôhmica através do eletrólito pode-se diminuir a espessura do eletrólito de $100-500 \mu \mathrm{m}$ para $5-20 \mu \mathrm{m}$, fato este que implica no uso do anodo como suporte. Neste caso, a cerâmica (Ni-YSZ) tem sido geralmente selecionada como suporte porque proporciona uma maior condutividade elétrica e térmica, boa resistência mecânica e mínima interação química com o eletrólito durante o processo de co-sinterização [23, 24].

O desempenho do anodo Ni-YSZ é altamente dependente não apenas do conteúdo de níquel, mas também da microestrutura. Para que os elétrons, íons oxigênio e gás combustível migrem para os sítios ativos conhecido como fase tripla reacional (TPB - Three Phase Boundary) é necessário que ocorra a percolação das fases $\mathrm{Ni}$, YSZ e gás. Esta estrutura complexa está diretamente relacionada com a dispersão da fase metálica $(\mathrm{Ni})$ na matriz cerâmica, com as condições dos pós de partida, granulometria e morfologia das partículas e, finalmente, com as técnicas de processamento cerâmico. O procedimento mais freqüentemente utilizado na fabricação deste componente consiste na 
homogeneização dos pós de NiO e YSZ por mistura mecânica, na estequiometria desejada. A mistura obtida é geralmente aplicada sobre 0 eletrólito de zircônia por técnicas de deposição de suspensões (serigrafia ou aspersão) e em seguida, sinterizada para formar um compósito cerâmico $\mathrm{NiO}$-YSZ. O NiO é então reduzido "in situ" a níquel metálico quando é exposto ao ambiente do combustível na SOFC [8]. Contudo, durante a manipulação da suspensão pode ocorrer a separação das partículas de $\mathrm{NiO}$ e YSZ devido à diferença na densidade dos pós, resultando em uma distribuição não uniforme no material implicando em baixo rendimento eletroquímico do anodo.

Diversas técnicas de sínteses, a partir de soluções químicas, estão sendo estudados para obtenção de pós precursores com alta pureza, homogeneidade, dimensões nanométricas e estequiometria controlada, com 0 objetivo de obter um melhor controle da microestrutura do material para anodo. Dentre estas técnicas utilizadas para obtenção destes pós com composição homogênea e alta sinterabilidade destacam-se a coprecipitação de hidróxidos a partir de soluções aquosas e reação por combustão [25].

A coprecipitação é dentre os métodos químicos, o mais utilizado para obtenção de insumos cerâmicos em escala industrial devido à simplicidade do processo e a possibilidade de mistura dos precursores em escala atômica na solução inicial, resultando em um pó com um alto grau de dispersão e homogeneidade química e física. Nesta técnica, o agente precipitante mais freqüentemente utilizado é o $\mathrm{NH}_{4} \mathrm{OH}$ devido ao baixo custo e pela possibilidade de remoção do amônio por volatilização na secagem e calcinação. Contudo, na síntese do compósito NiO-YSZ é necessário um controle rigoroso na adição deste precipitante, pois em baixa concentração $\mathrm{Ni}(\mathrm{OH})_{2}$ não é precipitado totalmente e, em excesso, leva a formação de complexos solúveis na forma de $\left[\mathrm{Ni}\left(\mathrm{NH}_{3}\right)_{n}\right]^{2+}(1 \leq \mathrm{n} \leq 6)[26]$.

A síntese por combustão, também denominada de síntese por reação autopropagante de alta temperatura, tem sido considerada uma alternativa promissora por ser um processo simples e rápido, em que os pós são obtidos em uma única etapa, não necessitando de etapas intermediarias de calcinação. A grande dificuldade neste processo é controlar a extensão da reação que 
depende da quantidade estequiométrica das espécies envolvidas, portanto, os principais parâmetros a serem controlados neste processo são: pH e relação estequiométrica entre o combustível e soluções de nitrato [27, 28].

De acordo com as citações na literatura, é consenso que as desvantagens, de cada método de síntese têm grande influência na microestrutura do produto final e, conseqüentemente, no desempenho da célula.

A etapa do processamento cerâmico relativa à conformação dos pós é considerada também uma etapa crítica para obtenção de peças cerâmicas com alta homogeneidade química e microestrutural. A conformação dos pós a partir de suspensão coloidal é reconhecida como uma das rotas mais atraentes para obtenção de cerâmicas para aplicações eletrônicas devido ao melhor empacotamento das partículas no corpo a verde, o que permite melhor controle microestrutural durante o processo de sinterização. Nessa técnica de conformação, a avaliação das características dos pós é muito importante no controle do processo de conformação, pois as propriedades da superfície da partícula no meio afetam a estabilização de uma suspensão devido a sua elevada área superficial por unidade de volume. Esses sistemas de suspensões são bastante influenciados por forças entre partículas, dentre as quais se destaca a força atrativa de van der Waals e força repulsiva causada por íons adsorvidos na superfície da partícula. Em virtude disso, é importante conhecer o mecanismo de estabilização de uma suspensão coloidal [29, 30].

Com a otimização dos parâmetros de conformação, assegura-se uma distribuição uniforme das partículas de $\mathrm{Ni}^{0}$ dentro da matriz YSZ e uma microestrutura homogênea, mesmo durante o processo de sinterização. Para aplicação em SOFC, as condições consideradas apropriadas para obtenção de um compósito são: porosidade de 10 - 20\% após a sinterização, concentração de Ni entre 42 e 54\% em massa e temperatura de sinterização entre 1250 e $1350{ }^{\circ} \mathrm{C}$, que corresponde à faixa de alta taxa de sinterização deste tipo de material. A densificação e tamanho dos poros aumentam com a quantidade de $\mathrm{NiO}$ no compósito devido a maior densidade dos pós de $\mathrm{NiO}$ e a possibilidade de coalescência dos grãos durante a sinterização e redução. E este último comportamento é justificado pelo maior crescimento dos grãos de $\mathrm{NiO}$, devido 
à diferença na sinterabilidade entre a fase $\mathrm{NiO}$ e YSZ e da necessidade de extrair mais oxigênio durante a redução para $\mathrm{Ni}^{0}$. De uma maneira geral, observa-se que o crescimento dos grãos de YSZ ocorre somente durante a sinterização, enquanto que as partículas de $\mathrm{Ni}^{0}$, além do crescimento durante a sinterização, apresentam um aumento adicional durante a redução. Como o coeficiente de expansão térmica do níquel é maior do que YSZ, esta diferença de valores pode provocar fratura ou delaminação do corpo cerâmico durante a sinterização, sendo, portanto um fator importante a ser considerado no processo de fabricação do compósito e integridade do corpo cerâmico [31].

$\mathrm{Na}$ redução do $\mathrm{NiO}$ para $\mathrm{Ni}^{0}$ pelo $\mathrm{H}_{2}$, o estudo da interação entre $\mathrm{NiO}$ e YSZ pelo método da redução com temperatura programada (TPR) permite identificar o grau de interação entre $\mathrm{NiO}$ e a matriz cerâmica e temperatura mínima para que a redução comece a ocorrer. No estudo da redução do $\mathrm{NiO}$, sem a presença da matriz, um dos métodos consiste na análise da redução "in situ" por difração de raios $X$, dos produtos de reação da redução. Esta técnica permite a verificação simultânea da diminuição da fase $\mathrm{NiO}$ e formação da fase metálica, Ni. O método utilizado para determinar a temperatura programada de redução, consiste da medida do consumo de hidrogênio [32].

Das etapas do processamento cerâmico, acima mencionadas, segundo os dados da literatura, os seguintes aspectos importantes podem ser observados:

- O processo de obtenção de NiO-YSZ pelo método da coprecipitação, usando $\mathrm{NH}_{4} \mathrm{OH}$ como agente precipitante, apesar da simplicidade de processo, não tem sido utilizado devido ao baixo rendimento na precipitação do $\mathrm{Ni}(\mathrm{OH})_{2}$.

- Embora a mistura mecânica dos pós NiO e YSZ seja a técnica mais empregada na fabricação do compósito NiO-YSZ, os procedimentos e métodos para obtenção do compósito não são detalhados.

- Na etapa que envolve a conformação dos pós NiO-YSZ para obtenção de corpo cerâmico, não existe uma padronização para formulação da suspensão coloidal, parâmetros estes que dependem das propriedades físicas e químicas dos pós. 
- A difratometria de raios $X$ e termogravimetria (TG) são técnicas freqüentemente empregadas nos estudos da cinética de reação de redução do $\mathrm{NiO}$ para $\mathrm{Ni}^{0}$ e na cinética de sinterização. Estudo da interação entre $\mathrm{NiO}$ e YSZ, utilizando estas técnicas, tem visado o estudo de redução com temperatura programada (TPR). 


\section{II - OBJETIVO}

- Tendo em vista a necessidade de realização de estudos mais detalhados para esclarecimento e consolidação de algumas rotas de síntese e processamento do compósito NiO-YSZ, com propriedades necessárias para aplicação como anodo em Células a Combustível do tipo Óxido Sólido (SOFC), a proposta deste trabalho foi, em uma primeira etapa, estudar as técnicas de síntese deste compósito por mistura de pós e métodos químicos de coprecipitação e por combustão. Neste sentido, os principais aspectos abordados nestes estudos foram:

a) Avaliação da influência dos parâmetros de processo de coprecipitação, tais como concentração de reagentes, $\mathrm{pH}$ e temperatura, na formação de $\mathrm{Ni}(\mathrm{OH})_{2}$ e também em presença dos cátions $\mathrm{Zr}(\mathrm{IV})$ e Y(III).

b) $\mathrm{Na}$ síntese por combustão, verificar o efeito da relação estequiométrica entre o combustível e as soluções de nitrato contendo os cátions metálicos de interesse de maneira a obter a melhor cristalinidade dos pós.

c) Estudo do comportamento reológico da mistura de pós de $\mathrm{NiO}$ e YSZ, visando a obtenção de mistura homogênea dos pós em função da estabilização das suspensões.

- Definidos os parâmetros de processo de cada método de síntese, a etapa seguinte envolveu a definição das condições de processamento cerâmico dos pós obtidos. Amostras preparadas por prensagem uniaxial foram sinterizadas em condições determinadas em ensaios de dilatometria e avaliados os seguintes itens:

- Homogeneidade de distribuição das fases formadas pela avaliação microestrutural

- Estudo da cinética de redução do NiO por técnica de análise térmica, em atmosfera de $\mathrm{H}_{2}$.

- Avaliar a influência da presença de formadores de poros na cinética de 
redução do NiO nos corpos cerâmicos obtidos pelos três métodos de síntese

- Comparação das características microestruturais das cerâmicas obtidas, antes e após a redução do $\mathrm{NiO}$. 


\section{III - ASPECTOS RELEVANTES DA LITERATURA}

\section{III.1 - Considerações gerais sobre as cerâmicas de zircônia estabilizada e os compósitos NiO-YSZ e Ni-YSZ}

A zircônia pura apresenta sob temperatura e pressão ambiente a estrutura monoclínica, transformando-se na fase tetragonal em $1100{ }^{\circ} \mathrm{C}$ e em cúbica do tipo fluorita em $2370{ }^{\circ} \mathrm{C}$, a qual é estável até o ponto de fusão $\left(2700^{\circ} \mathrm{C}\right)$. As fases, tetragonal e cúbica se transformam em monoclínica quando resfriada à temperatura ambiente. Por isso, na etapa de resfriamento do processo de sinterização ocorre uma expansão volumétrica na faixa de 3 a $5 \%$, sendo expansão associada à transformação da fase tetragonal para monoclínica. A mudança de volume causa trincas e fraturas nos corpos cerâmicos, o que inviabiliza o seu uso na forma de $\mathrm{ZrO}_{2}$ puro [33]. Contudo, esta transformação de fase pode ser evitada pela estabilização da fase tetragonal com a adição controlada de agentes estabilizantes tais como $\mathrm{MgO}$, $\mathrm{CaO}, \mathrm{CeO}_{2}, \mathrm{Sc}_{2} \mathrm{O}_{3}$ e $\mathrm{Y}_{2} \mathrm{O}_{3}$, que permitem que as fases polimórficas de alta temperatura possam ser estabilizadas, parcialmente ou totalmente, em temperatura ambiente [34].

$\mathrm{O}$ óxido de ítrio $\left(\mathrm{Y}_{2} \mathrm{O}_{3}\right)$ é um eficiente estabilizante, com uma larga faixa de aplicação em cerâmica à base de zircônia por apresentar muitas características interessantes para aplicações industriais. A concentração do $\mathrm{Y}_{2} \mathrm{O}_{3}$ é fundamental para a definição das propriedades desses materiais, especialmente a resistência mecânica, tenacidade à fratura e condutividade iônica [35].

Conforme pode ser observado no diagrama de fases da Fig. 1, as cerâmicas com baixo conteúdo de $\mathrm{Y}_{2} \mathrm{O}_{3}(2-4$ mol\%) estabilizam a fase tetragonal, podendo ser usadas como material estrutural, onde alta resistência mecânica e tenacidade à fratura são requisitos necessários [36]. Por outro lado, propriedade como baixa condutividade térmica e alta condutividade iônica são obtidas pela estabilização da fase cúbica da zircônia com $6-10$ mol\% de $\mathrm{Y}_{2} \mathrm{O}_{3}$, características estas interessantes para aplicações em sensores de oxigênio, eletrólitos para célula a combustível e barreira térmica [6, 37]. 


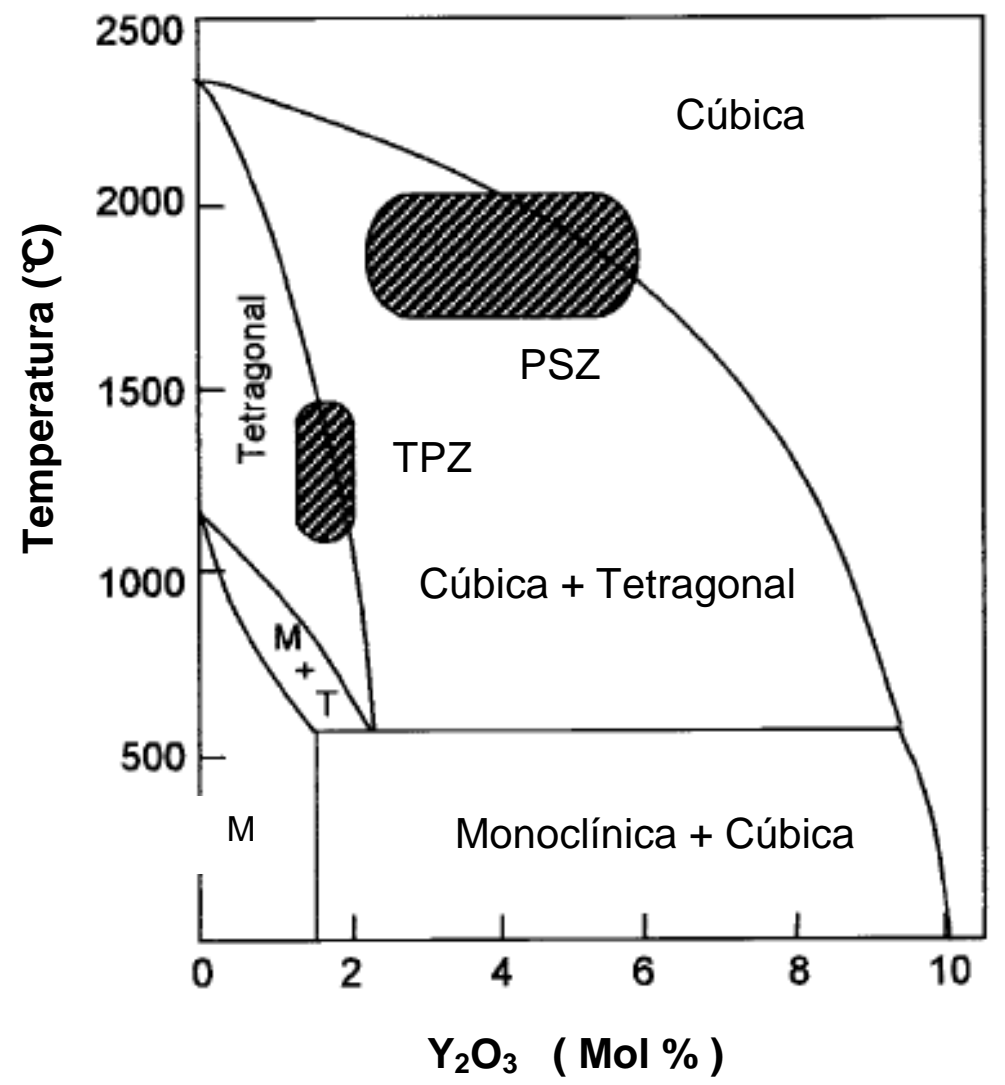

Figura 1 - Diagrama de fases do sistema $\mathrm{ZrO}_{2}-\mathrm{Y}_{2} \mathrm{O}_{3}$, proposto por Hannink et al., onde $\mathrm{M}, \mathrm{T}$ e $\mathrm{C}$ representa, as fases monoclínica, tetragonal e cúbica respectivamente e L, a fase líquida zircônia - ítria [38]

Atualmente, as pesquisas de síntese de NiO/YSZ e processamento cerâmico estão relacionadas ao desenvolvimento da tecnologia de célula a combustível para geração de energia limpa. O estado da arte na fabricação do anodo da célula a combustível de óxido sólido (SOFC) é o compósito de níquel - zircônia estabilizada com 8 mol\% de ítria (Ni-8YSZ) obtido pela redução "in situ" do NiO-8YSZ [6]. As partículas de níquel, que formam uma rede percolativa, têm uma atividade catalítica para oxidação do hidrogênio e são responsáveis pelo transporte dos elétrons da zona de reação para um circuito externo [37 - 39].

A incorporação de partículas metálicas ou óxidos metálicos na zircônia estabilizada com $8 \mathrm{~mol} \%$ de ítria (YSZ) possibilita o desenvolvimento de condutor misto (iônico-eletrônico). Entre os óxidos metálicos, com um vasto campo de aplicação, destaca-se o $\mathrm{NiO}$, onde o mecanismo de condução depende da composição entre NiO e YSZ. 
A vantagem na escolha de $\mathrm{NiO} / \mathrm{Ni}$, como fase condutora de elétrons, inclui o seu baixo custo, a estabilidade em uma vasta faixa de temperatura, a limitada solubilidade em solução sólida $\left(<2 \mathrm{~mol} \%\right.$ a $\left.1600{ }^{\circ} \mathrm{C}\right) \mathrm{com}$ YSZ e a ausência de produto de reação ou fases intermediarias [6, 38 - 40].

No anodo, a função do YSZ é servir de suporte para as partículas de níquel, proporcionar um coeficiente de expansão térmica próximo aos outros componentes da célula e, contribuir na formação de trajetória contínua para o transporte do íon oxigênio, aumentando assim a área ativa para reação no eletrodo.

\section{III.2 - Métodos de síntese do compósito NiO-YSZ}

Para se obter as propriedades desejadas em cada uma das aplicações acima citadas, são fundamentais o controle da microestrutura, fase cristalina, distribuição de tamanho de partícula e homogeneidade dos pós precursores da cerâmica. Dentre as técnicas utilizadas para obtenção de pó precursor com composição homogênea e alta sinterabilidade destacam-se a precipitação química [41, 42], o processo hidrotérmico [43,44], a combustão $[45,46]$ e o processo sol-gel $[47,48]$.

\section{III.2.1 - A química do níquel}

Para obtenção do compósito NiO-YSZ, empregando-se métodos de síntese química, é necessário compatibilizar o processamento e reagentes dos cátions $\mathrm{Ni}^{2+}$ com a técnica de síntese do YSZ. Atualmente, a pesquisa relacionada à síntese de pós de $\mathrm{Ni}(\mathrm{OH})_{2}$ tem sido direcionada principalmente para a utilização na tecnologia de baterias como material catódico [49].

$\mathrm{O} \mathrm{Ni}(\mathrm{OH})_{2}$ pode ser sintetizado em duas formas polimórficas, $\alpha-\mathrm{Ni}(\mathrm{OH})_{2}$ e $\beta-\mathrm{Ni}(\mathrm{OH})_{2}$. Estas duas formas se cristalizam no sistema hexagonal com a estrutura tipo "brucita" e empilhamento de camadas de $\mathrm{Ni}(\mathrm{OH})_{2}$. A fase $\beta-\mathrm{Ni}(\mathrm{OH})_{2}$ é um hidróxido anidro com uma estrutura ao longo do eixo "c" bem ordenada e com separação entre camada de $0,46 \mathrm{~nm}$. A fase $\alpha-\mathrm{Ni}(\mathrm{OH})_{2}$, que é um hidróxido hidratado, tem uma separação entre camada de 0,8 a $0,9 \mathrm{~nm}$, dependendo do raio iônico do ânion, intercalado entre as camadas de $\mathrm{Ni}(\mathrm{OH})_{2}$. Apresenta moléculas de água e ânions adsorvidos nos espaços entre planos de $\mathrm{Ni}(\mathrm{OH})_{2}$ e exibe uma estrutura desordenada. Esta fase é metaestável e 
transforma-se em $\beta-\mathrm{Ni}(\mathrm{OH})_{2}$ durante a síntese, ou quando estocado em meio fortemente alcalino [40].

De acordo com relatos da literatura, o difratograma de difração de raios $\mathrm{X}$ para o $\alpha-\mathrm{Ni}(\mathrm{OH})_{2}$ apresenta picos para $2 \theta(\mathrm{Cu} \mathrm{K \alpha})$ iguais a $11^{\circ} ; 22^{\circ} ; 33,5^{\circ} \mathrm{e}$ $60^{\circ}$ e os picos em 2,0 $; 19,1^{\circ} ; 33,2^{\circ} ; 38,5^{\circ}$ e $59,2^{\circ}$ correspondente ao $\beta-\mathrm{Ni}(\mathrm{OH})_{2} \cdot[49]$.

O controle das características dos pós é fator essencial para se obter melhor capacidade eletroquímica do hidróxido. Para atingir este objetivo é necessário controlar os parâmetros de síntese (concentração do sal, temperatura, $\mathrm{pH}$, velocidade de agitação). Entre as técnicas de sîntese destacam-se a precipitação química e deposição eletroquímica ou eletrossíntese.

A rota mais eficiente para síntese do $\alpha-\mathrm{Ni}(\mathrm{OH})_{2}$ é a redução eletroquímica em solução aquosa na presença de $\mathrm{Ni}\left(\mathrm{NO}_{3}\right)_{2}$. Neste mecanismo de eletrólise ocorre a oxidação da água no anodo e a redução dos íons nitrato no cátodo. Esta redução gera $\mathrm{NH}_{4} \mathrm{OH}$ e íons $\mathrm{OH}^{-}$na vizinhança do eletrodo causando a precipitação do $\mathrm{Ni}(\mathrm{OH})_{2}$, conforme as reações abaixo [50]:

$$
\begin{gathered}
\mathrm{NO}_{3(\mathrm{aq})}^{-}+7 \mathrm{H}_{2} \mathrm{O}_{(\mathrm{l})}+8 \mathrm{e}^{-} \rightarrow \mathrm{NH}_{4} \mathrm{OH}_{(\mathrm{aq})}+9 \mathrm{OH}_{(\mathrm{aq})}^{-} \\
\mathrm{Ni}_{(\mathrm{aq})}^{2+}+2 \mathrm{OH}_{(\mathrm{aq})}^{-} \rightarrow \mathrm{Ni}(\mathrm{OH})_{2(\mathrm{~s})} \downarrow
\end{gathered}
$$

Para obter o $\mathrm{Ni}(\mathrm{OH})_{2}$, na forma $\beta$, o método da precipitação é o mais utilizado. Uma das formas de obtenção consiste em complexar o $\mathrm{Ni}^{2+} \mathrm{com}$ hidróxido de amônio e em seguida utilizar uma base forte como agente precipitante [51, 52]. Yang et al. analisaram a influência da concentração do agente precipitante $(\mathrm{NaOH})$ e concluíram que em meio fortemente alcalino ( $p \geq 13$ ) são obtidos partículas com formato esférico e tamanhos uniformes tamanhos uniformes. Keklikian et al. estudaram a precipitação do $\mathrm{Ni}(\mathrm{OH})_{2}$ a partir de soluções aquosas de nitrato, sulfato, cloreto ou perclorato com $\mathrm{Na}(\mathrm{OH}), \quad \mathrm{NH}_{4} \mathrm{OH}$ ou $\mathrm{CO}\left(\mathrm{NH}_{2}\right)_{2}$. Observaram que em solução de nitrato e $\mathrm{NH}_{4} \mathrm{OH}$ como agente precipitante as partículas apresentaram-se na forma de placas, enquanto em solução de sulfato e $\mathrm{CO}\left(\mathrm{NH}_{2}\right)_{2}$ como agente precipitante as partículas produzidas eram esféricas $[53,54]$. 
Notas-se que a técnica de precipitação de hidróxidos metálicos na presença de hidróxido de amônio é muito utilizada, visto que um número razoável de íons metálicos pode ser precipitado na presença de quantidade variável de íons hidroxilas $\left(\mathrm{OH}^{-}\right)$. A concentração dos íons hidroxila em uma solução pode ser controlada utilizando-se o efeito da presença de sais de amônio $\left(\mathrm{NH}_{4}^{+}\right)$que promove a hidrólise e formação de base fraca.

A precipitação do níquel na presença de hidróxido de amônio é expressa pelas seguintes reações:

$$
\begin{aligned}
& \mathrm{Ni}_{(\mathrm{aq})}^{2+}+2 \mathrm{OH}^{-} \rightarrow \mathrm{Ni}(\mathrm{OH})_{2(\mathrm{~s})} \downarrow \\
& \mathrm{NH}_{4}{ }^{+}{ }_{\text {(aq })}+\mathrm{OH}^{-}{ }_{(\mathrm{aq})} \rightleftarrows \mathrm{NH}_{3(\mathrm{aq})}+\mathrm{H}_{2} \mathrm{O}_{(\mathrm{l})} \\
& \text { M } \\
& \mathrm{NH}_{4} \mathrm{OH}_{(\text {aq) }} \\
& \mathrm{K}_{\mathrm{b}}=\frac{\mathrm{a}_{\mathrm{NH}_{4}^{+}} \mathrm{a}_{\mathrm{OH}^{-}}}{\mathrm{a}_{\mathrm{NH}_{3}^{+}} \mathrm{a}_{\mathrm{NH}_{4} \mathrm{OH}}}
\end{aligned}
$$

onde: $\mathrm{K}_{\mathrm{b}}=$ constante de equilíbrio da reação de ionização da base $\mathrm{NH}_{3}$;

$$
\begin{aligned}
& \mathrm{a}_{\mathrm{NH}_{4}^{+}}=\text {atividade do íon amônio; } \\
& \mathrm{a}_{\mathrm{OH}^{-}}=\text {atividade do íon } \mathrm{OH}^{-} ; \\
& \mathrm{a}_{\mathrm{NH}_{3}^{+}}=\text {atividade da espécie } \mathrm{NH}_{3} ; \\
& \mathrm{a}_{\mathrm{NH}_{4} \mathrm{OH}}=\text { atividade da espécie } \mathrm{NH}_{4} \mathrm{OH} .
\end{aligned}
$$

O precipitado é verde e gelatinoso, porém em excesso de amônia forma complexos solúveis.

Para a precipitação de um metal $\mathrm{M}$ ocorrer é necessário que o produto da atividade ou concentração das espécies que participam da reação de precipitação exceda o produto de solubilidade $\left(\mathrm{K}_{\mathrm{ps}}\right)$. O produto de solubilidade $\mathrm{K}_{\mathrm{ps}}$ do $\mathrm{M}(\mathrm{OH})_{\mathrm{x}}$ é dada por:

$$
\mathrm{M}(\mathrm{OH})_{\mathrm{x}} \rightleftarrows \mathrm{M}^{\mathrm{x}+}+\mathrm{x} \cdot \mathrm{OH}^{-}
$$




$$
\begin{gathered}
\mathrm{K}_{\mathrm{ps}}=\mathrm{a}_{\mathrm{M}^{\mathrm{x}}}\left(\mathrm{a}_{\mathrm{OH}^{-}}\right)^{x} \\
\mathrm{a}_{\mathrm{OH}^{-\mathrm{x}}}=\frac{\mathrm{K}_{\mathrm{ps}}}{\mathrm{a}_{\mathrm{M}^{\mathrm{x}}}} \\
\mathrm{a}_{\mathrm{OH}^{-}} \mathrm{x}=\sqrt[\mathrm{x}]{\frac{\mathrm{K}_{\mathrm{ps}}}{\mathrm{a}_{\mathrm{M}^{\mathrm{x}}}}}=\left(\frac{\mathrm{K}_{\mathrm{ps}}}{\mathrm{a}_{\mathrm{M}^{\mathrm{x}}}}\right)^{\frac{1}{\mathrm{x}}} \\
-\log a_{O H^{-}}=-\log \left(\frac{\mathrm{K}_{\mathrm{ps}}}{\mathrm{a}_{\mathrm{M}^{\mathrm{x}}}}\right)^{\frac{1}{x}} \\
\mathrm{pOH}=-\log \left(\frac{\mathrm{K}_{\mathrm{ps}}}{\mathrm{a}_{\mathrm{M}^{\mathrm{x}}}}\right) \\
\mathrm{pOH}+\mathrm{pH}=14
\end{gathered}
$$

A substituição da expressão $\mathrm{pOH}$ da equação III.2.1.11 na equação III.2.1.12 permite descrever a concentração de uma espécie metálica dissolvida em uma solução aquosa em função do pH.

$$
\log \left(\frac{K_{p s}}{a_{M^{x+}}}\right)+p H=14
$$

A Fig.2 mostra a curva de solubilidade do $\mathrm{Ni}(\mathrm{OH})_{2}$ em função do $\mathrm{pH}$. Esta curva corresponde à equação da reta cuja inclinação da reta é igual à $-x$ (valência do íon) [55]. 


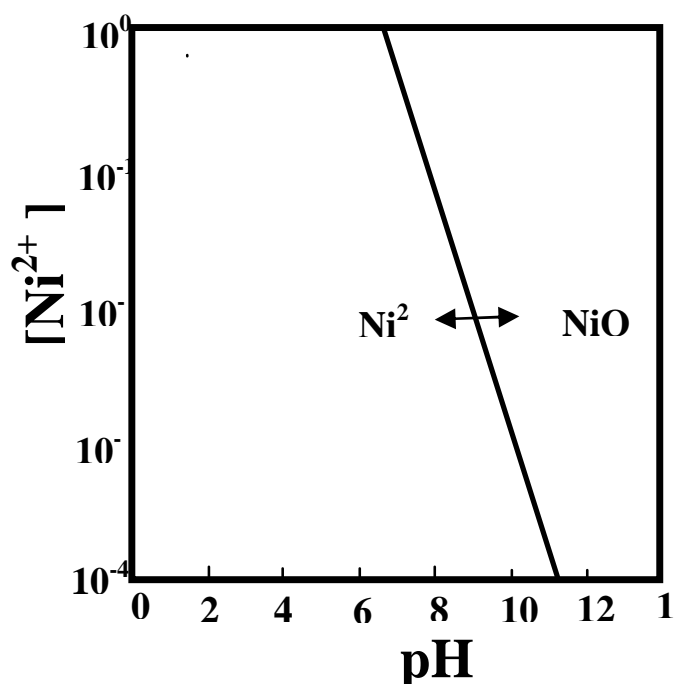

Figura 2 - Curva de solubilidade de $\mathrm{Ni}(\mathrm{OH})_{2}$ a $25^{\circ} \mathrm{C}$

Para o precipitado de $\mathrm{Ni}(\mathrm{OH})_{2}$ a expressão de solubilidade é:

$$
\mathrm{K}_{\mathrm{ps}}=\mathrm{a}_{\mathrm{Ni}^{2}}+\mathrm{a}_{\mathrm{OH}^{-}}-2
$$

onde: $\mathrm{a}_{\mathrm{Ni}^{2+}}$ e $\mathrm{a}_{\mathrm{OH}^{-2}}$ são as atividades dos íns $\mathrm{Ni}^{2+} \mathrm{e} \mathrm{OH}^{-}$, respectivamente.

$\mathrm{K}_{\mathrm{ps}}$ representa o máximo valor que o produto das atividades dos íons pode ter para uma condição de solubilidade em uma dada temperatura. Existem duas condições que explica o fenômeno de precipitação:

(a) Solução saturada: Em uma solução saturada, o produto das atividades dos íons é menor ou igual o valor de $\mathrm{K}_{\mathrm{ps}}$ ou $\mathrm{a}_{\mathrm{Ni}^{2}} \mathrm{a}_{\mathrm{OH}^{-2}} \leq \mathrm{K}_{\mathrm{ps}}$. Neste caso, se $\mathrm{Ni}(\mathrm{OH})_{2}$ não dissolvido estiver presente, irá dissolver para buscar a condição de equilíbrio

(b) Solução supersaturada: Em uma solução supersaturada, se o produto da atividade dos íons for maior do que $\mathrm{K}_{\mathrm{ps}}$ ou $\mathrm{a}_{\mathrm{Ni}^{2+}} \mathrm{a}_{\mathrm{OH}^{-}}{ }^{2}>\mathrm{K}_{\mathrm{ps}}$. Neste caso, se as forças internas permitirem a nucleação dos cristais, então a precipitação ocorrerá até que as concentrações atinjam a condição de solução saturada.

$\mathrm{Na}$ precipitação do $\mathrm{Ni}(\mathrm{OH})_{2}$, partindo-se de uma solução de $\mathrm{NiCl}_{2} \cdot 6 \mathrm{H}_{2} \mathrm{O}$, temos no equilíbrio:

$$
\mathrm{a}_{\mathrm{Ni}^{2+}}=\mathrm{a}_{\mathrm{H}^{+}} \frac{\mathrm{K}_{\mathrm{ps}}}{\mathrm{K}_{\mathrm{w}^{2}}}
$$




$$
\mathrm{K}_{\mathrm{ps}}=\mathrm{a}_{\mathrm{Ni}^{2+}} \mathrm{a}_{\mathrm{OH}^{-2}}=\mathrm{a}_{\mathrm{Ni}^{2+}} \frac{\mathrm{K}_{\mathrm{w}^{2}}}{\mathrm{a}_{\mathrm{H}^{+}}}
$$

E a fração precipitada ( $\eta$ ) é dada por:

$$
\eta=\frac{\mathrm{m}-\left[\mathrm{Ni}^{2+}\right]_{\mathrm{T}}}{\mathrm{m}}=1-\frac{\left[\mathrm{Ni}^{2+}\right]_{\mathrm{T}}}{\mathrm{m}}
$$

onde: $\mathrm{m}=$ concentração inicial da solução de $\mathrm{NiCl}_{2} \cdot 6 \mathrm{H}_{2} \mathrm{O}$ em mol. $\mathrm{L}^{-1}$

$\left[\mathrm{Ni}^{2+}\right]_{\mathrm{T}}=$ concentração de $\mathrm{Ni}^{2+}$ em solução, podendo assumir que $\mathrm{a}_{\mathrm{Ni}^{2+}} \cong\left[\mathrm{Ni}^{2+}\right]$.

Zhong et al desenvolveram um método de cálculo para expressar a relação de equilíbrio entre uma fase sólida associada com a fase aquosa em termos de concentração total das espécies dissolvidas [56]. Para um dado sistema aquoso, o diagrama de equilíbrio, diagrama de potencial-pH, curva de solubilidade e curva de voltagem-taxa de concentração podem ser calculados em função da adição de amônia. Um exemplo de cálculo de precipitação de $\mathrm{Mg}(\mathrm{OH})_{2}$ foi realizado para uma solução de cloreto de magnésio. Este método de cálculo pode ser aplicado analogamente para o sistema níquel-amônia-água.

O aumento na concentração de amônia conduz à formação de complexos entre o níquel e a amônia na forma de $\left[\mathrm{Ni}_{(}\left(\mathrm{NH}_{3}\right)_{n}\right]^{2+}$ onde $1 \leq \mathrm{n} \leq 6$. Como as moléculas de água são fracamente ligadas ao $\mathrm{Ni}^{2+}$, as moléculas de amônia começam a competir e sucessivamente vão substituindo as moléculas de água formando complexos solúveis de níquel conforme reação:

$\left.\mathrm{Ni}^{2+}{ }_{(\mathrm{aq})}+\mathrm{nNH}_{3(\mathrm{aq})}+(6-\mathrm{n}) \cdot \mathrm{H}_{2} \mathrm{O}{ }_{(\mathrm{l})} \longrightarrow\left[\mathrm{Ni} \cdot\left(\mathrm{NH}_{3}\right)_{\mathrm{n}} \cdot\left(\mathrm{H}_{2} \mathrm{O}\right)_{(6}-\mathrm{n}\right)\right]_{(\text {aq) }}{ }^{2+} \quad$ (III.2.1.18) onde: $1 \leq \mathrm{n} \leq 6$

A formação dos complexos solúveis de níquel pode ser comprovada pela mudança da cor da solução, que é uma propriedade característica dos complexos de transição. Quando hidróxido de amônio é colocado em excesso ocorrem as seguintes transformações: em água, o níquel (II) apresenta-se como um complexo $\left[\mathrm{Ni}\left(\mathrm{H}_{2} \mathrm{O}\right)_{6}\right]^{2+}$ de cor verde; ao adicionar $\mathrm{NH}_{3}$ as estruturas de ligantes mistos de $\mathrm{Ni}\left(\mathrm{NH}_{3}\right)_{x}\left[\left(\mathrm{H}_{2} \mathrm{O}\right)_{(6-x)}\right]^{2+}$ são formadas e co-existem em solução aquosa.

Os parâmetros termodinâmicos para sistema níquel - amônia - água são apresentados na Tab. 1. 
Grgicak et al mediram espectro na região visível dos complexos [Ni. $\left.\left(\mathrm{NH}_{3}\right)_{n} \cdot\left(\mathrm{H}_{2} \mathrm{O}\right)_{6-n}\right]^{2+}$ formados durante a coprecipitação com amônia (Fig 3) [57].

As proporções relativas das espécies dependem da quantidade de $\mathrm{NH}_{3}$ adicionada à solução aquosa de $\mathrm{Ni}^{2+}$. Quando $\mathrm{NH}_{3}$ é adicionado em excesso, $\mathrm{O}$ íon complexo $\left[\mathrm{Ni}\left(\mathrm{NH}_{3}\right)_{6}\right]^{2+}$ de cor azul é formado, o que indica que está absorvendo a luz laranja. Como o complexo $\left[\mathrm{Ni}\left(\mathrm{NH}_{3}\right)_{6}\right]^{2+}$ absorve a luz vermelha $(650 \mathrm{~nm})$ de menor energia, que a luz laranja $(600 \mathrm{~nm})$, a amônia substitui a água e forma uma ligação mais forte [58].

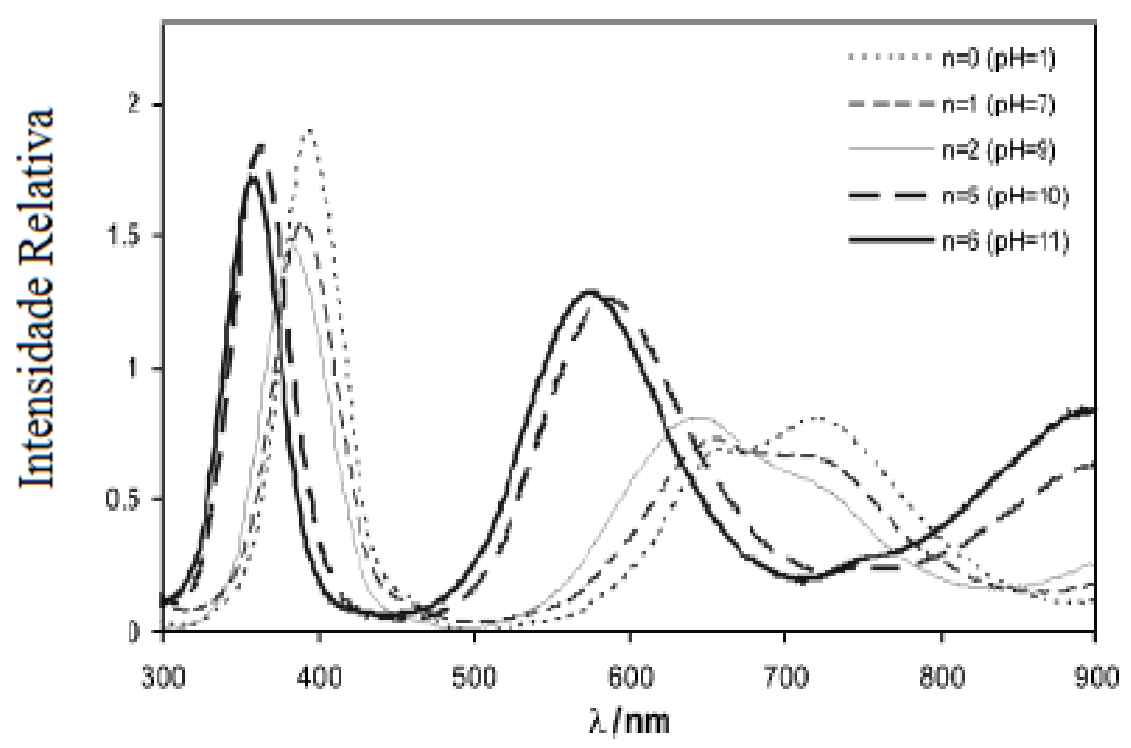

Figura 3 - Espectro visível da luz dos complexos $\left[\mathrm{Ni}\left(\mathrm{NH}_{3}\right)_{n} \cdot\left(\mathrm{H}_{2} \mathrm{O}\right)_{6-n}\right)$ $1 \leq \mathrm{n} \leq 6$ em função do $\mathrm{pH}$ de precipitação com amônia [56] 
Tabela 1 - Dados termodinâmicos para o sistema Ni- $\mathrm{NH}_{3}-\mathrm{H}_{2} \mathrm{O}$ [55]

\begin{tabular}{ccc}
\hline \hline Reação & Propriedade & $\begin{array}{c}\text { Valores de constante de } \\
\text { equilibrio } \\
100^{\circ} \mathrm{C}\end{array}$ \\
\hline \hline $\mathrm{Ni}^{2+}+\mathrm{NH}_{3}=\mathrm{Ni}\left(\mathrm{NH}_{3}\right)^{2+}$ & $\mathrm{B}_{1}$ & $10^{1,92}$ \\
$\mathrm{Ni}^{2+}+2 \mathrm{NH}_{3}=\mathrm{Ni}\left(\mathrm{NH}_{3}\right)_{2}{ }^{2+}$ & $\mathrm{B}_{2}$ & $10^{3,50}$ \\
$\mathrm{Ni}^{2+}+3 \mathrm{NH}_{3}=\mathrm{Ni}\left(\mathrm{NH}_{3}\right)_{3}{ }^{2+}$ & $B_{3}$ & $10^{4,51}$ \\
$\mathrm{Ni}^{2+}+4 \mathrm{NH}_{3}=\mathrm{Ni}\left(\mathrm{NH}_{3}\right)_{4}{ }^{2+}$ & $B_{4}$ & $10^{5,08}$ \\
$\mathrm{Ni}^{2+}+5 \mathrm{NH}_{3}=\mathrm{Ni}\left(\mathrm{NH}_{3}\right)_{5}{ }^{2+}$ & $B_{5}$ & $10^{5,26}$ \\
$\mathrm{Ni}^{2+}+6 \mathrm{NH}_{3}=\mathrm{Ni}\left(\mathrm{NH}_{3}\right)_{6}{ }^{2+}$ & $B_{6}$ & $10^{4,44}$ \\
\hline \hline
\end{tabular}

onde: $E h^{0}$ é potencial padrão de redução para reação indicada em relação ao eletrodo padrão do hidrogênio;

$K_{w}$ é a constante de equilíbrio da água;

$\mathrm{K}_{\mathrm{N}}$ é constante de equilíbrio de formação dos íons amônia;

B é a constante de equilíbrio para formação dos complexos de níquel com diferentes quantidades do ligante $\mathrm{NH}_{3}$

\section{III.2.2 - Precipitação dos hidróxidos de Zr, Y e Ni}

$\mathrm{Na}$ literatura são relatados diversos métodos de preparação de pós de NiO-YSZ para assegurar uma distribuição uniforme das partículas de níquel dentro da matriz YSZ e uma microestrutura homogênea entre os quais podemos citar: mistura mecânica [38], precipitação de géis [48], solução tampão [49] e síntese de combustão [50].

A rota de coprecipitação surgiu como uma excelente alternativa, pois permite uma dispersão dos precursores em nível atômico já na solução inicial, resultando numa mistura de gel com um alto grau de homogeneidade que assegura uma distribuição uniforme das partículas de Ni na matriz cerâmica. 
$\mathrm{O}$ uso da solução tampão que consiste da mistura $\mathrm{NH}_{3} \cdot \mathrm{H}_{2} \mathrm{O}-\mathrm{NH}_{4} \cdot \mathrm{HCO}_{3}$ como agente precipitante em soluções aquosas de cloreto ou nitrato contendo os cátions de interesse tem como objetivo manter o pH da solução constante durante toda a precipitação. Esta técnica proporciona pós com formato arrendondados, tamanho nanométrico $(30 \mathrm{~nm})$ e distribuição homogênea do níquel no compósito de pós NiO-YSZ, que proporciona um aumento na condutividade em comparação ao método de mistura de pós. Os difratogramas de raios $\mathrm{X}$ mostram que os pós calcinados entre 800 e $1000{ }^{\circ} \mathrm{C}$ apresentam duas fases, fase cúbica da zircônia e $\mathrm{NiO}[59,60]$.

No método de coprecipitação proposto por Marinsek et al. a precipitação dos metais ocorre pela introdução de gás amônia (agente precipitante), na solução de cloreto contento os cátions $\mathrm{Zr}^{4+}, \mathrm{Y}^{3+}$ e $\mathrm{Ni}^{2+}$ [61]. Os dados da distribuição do tamanho de partículas revelam que os agregados primários, que são formados durante a precipitação e a subseqüente calcinação, formam aglomerados da ordem de alguns micrômetros. As densidades das amostras sinterizadas, sem redução do níquel, atingiram valores superiores a 97\%, e pela microscopia eletrônica de varredura, observou-se uma boa homogeneidade das fases cerâmica e metal, não notando domínio de uma única fase.

Em outro estudo de coprecipitação, Grgicak et al. utilizaram diferentes agentes precipitantes e caracterizaram os pós obtidos [57]. Os pós obtidos pela precipitação com amônia na forma de mistura gasosa, solução $\mathrm{NH}_{3}$ e $\mathrm{NaOH}$ apresentaram uma composição final próximo ao valor teórico, com um rendimento de precipitação de $\mathrm{NiO}$ de $80 \%$. A dispersão dos pós de $\mathrm{NiO}$ e YSZ mostrou-se homogênea com uma distribuição estreita de tamanho de partículas com uma dimensão de aproximadamente 44 e $40 \mathrm{~nm}$, respectivamente. No caso do uso de apenas $\mathrm{NaOH}$ como precipitante, o rendimento de precipitação foi praticamente idêntico ao obtido com procedimento anterior, porém os pós obtidos não apresentaram uma dispersão homogênea. $O$ tamanho de aglomerado de $\mathrm{NiO}$ foi praticamente o dobro $(90 \mathrm{~nm})$ enquanto para o YSZ foi praticamente o mesmo que do método anterior $(40-44 \mathrm{~nm})$. A síntese com $\mathrm{NH}_{3}$, introduzido na forma de gás, apresentou um baixo rendimento para o $\mathrm{NiO}$ devido à formação dos complexos solúveis de níquel. No caso, a composição 
real do compósito NiO-YSZ obtido após a precipitação foi de 12\% em massa de $\mathrm{NiO}$, enquanto a composição teórica estabelecida era de $50 \%$.

\section{III.2.3 - Métodos de síntese do compósito NiO-YSZ pela técnica de mistura mecânica dos pós}

A mistura mecânica dos pós é a técnica geralmente empregada para obtenção do compósito NiO-YSZ por ser um processo de baixo custo, fácil manipulação e composição química precisa. Neste método, os pós são submetidos à técnica de conformação que envolve a preparação de suspensões, como por exemplo, deposição por aspersão e colagem por barbotinas e colagem em fitas. Contudo, a diferença de densidade dos pós e a interação de partículas de óxidos distintos podem favorecer a instabilidade da suspensão e gerar uma distribuição não uniforme das partículas [62].

A estabilidade de uma suspensão depende da carga elétrica e magnitude da energia total de interação entre partículas. O princípio de estabilização por repulsão eletrostática é baseado na teoria DLVO (DerjaguinLandau-Verwey-Overbeek) que consiste em:

$$
V_{T}=V_{A}+V_{R}
$$

onde $V_{A}$ é a força de van der Waals e $V_{R}$ é a força eletrostática, estérica e outras interações [63].

As forças atrativas estão sempre presentes devido à tendência das partículas em permanecerem unidas por meio de forças de van der Waals. A interação repulsiva resulta do desenvolvimento de uma dupla camada ao redor de cada partícula em um líquido polar. O potencial elétrico originado na superfície das partículas atrai uma grande quantidade de íons de carga contrária formando uma monocamada rigidamente adsorvida à partícula, e uma dupla camada difusa na qual as concentrações de contra-íons diminuem com a distância. A região de desequilíbrio de cargas na interface partícula/líquido que engloba a camada de carga superficial da partícula ( $1^{\text {a }}$ camada) e os contraíons presentes nas camadas de Stern e difusa ( $2^{a}$ camada) são conhecidas como dupla camada elétrica da partícula. Após a formação da dupla camada elétrica, os contra-íons da camada de Stern e parte dos íons da camada difusa 
passam a formar uma nuvem iônica em torno da partícula. É na superposição das duplas camadas elétricas que origina a energia potencial de repulsão [30].

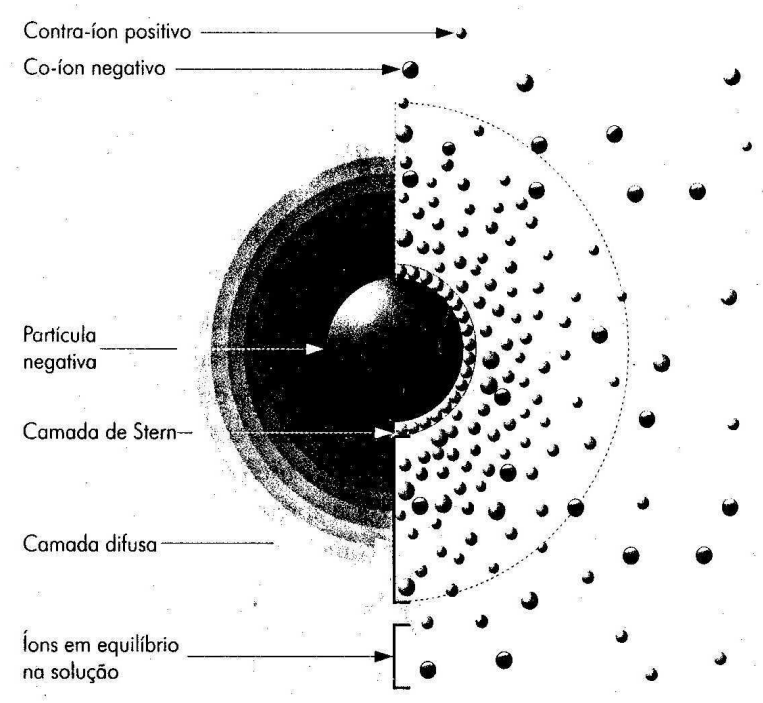

Figura 4 - Arranjo espacial dos íons que constituem a dupla camada elétrica de uma partícula carregada em um meio liquido [30]

Para avaliar a estabilidade dos pós em suspensão, a técnica normalmente adotada é a medida da mobilidade eletroforética. Esta medida consiste em aplicar um campo elétrico em uma suspensão e medir a velocidade de deslocamento das partículas. Esta medida permite calcular 0 valor do potencial zeta $(\zeta)$ a partir do valor da mobilidade eletroforética. Este potencial depende diretamente da concentração, na suspensão, do potencial dos íons determinantes, isto é, do valor de $\mathrm{pH}$ e sua natureza. Assim, quando diferentes pós são misturados em uma suspensão, a caracterização dos valores de potencial zeta versus $\mathrm{pH}$ para cada pó é um bom indicador do comportamento da suspensão. $O$ ponto isoelétrico é o parâmetro que permite distinguir o sinal da carga na superfície da partícula. Este parâmetro é determinado pela titulação de uma suspensão aquosa contendo sólido e sal 1:1, como por exemplo, $\mathrm{KCl}, \mathrm{NaCl}$ e $\mathrm{KNO}_{3}$, em diversas concentrações. Sabe-se que para um $\mathrm{pH}$ acima do ponto isoelétrico a superfície está negativamente carregada e positivamente carregada para $\mathrm{pH}$ abaixo.

Quando um polieletrólito é adicionado na suspensão ocorre um deslocamento do ponto isoelétrico para região ácida ou básica. Este deslocamento depende da natureza do polieletrólito. No caso de sal ácido de 
polimetacrilato de amônio (PMAA- $\mathrm{NH}_{3}$ ), Shojai et al. observaram que o ponto isoelétrico é deslocado para região ácida e que a adsorção do $\mathrm{PMAA}^{-\mathrm{NH}_{3}}$ atinge o seu ponto de saturação quando $o$ deslocamento do ponto isoelétrico passa a ser mínimo. Para uma adição maior de dispersante os valores do potencial zeta não apresentam alterações [64]. Na região ácida, em função da baixa fração de grupos dissociados, é necessário adicionar uma quantidade maior de polímero devido à maior adsorção de cadeia polimérica carregada negativamente sobre partículas carregadas positivamente. Para região de $\mathrm{pH}$ $>7$, acima do ponto isoelétrico dos pós, a fração de polímero dissociado aumenta, mas a carga superficial das partículas torna-se altamente negativa. Conseqüentemente, é necessária uma menor quantidade de $\mathrm{PMAA}^{-\mathrm{NH}_{3}}$ para obter uma suspensão com menor viscosidade. A quantidade de dispersante necessária para estabilização diminui com o aumento do $\mathrm{pH}$ da suspensão.

Em função do valor de potencial zeta é possível avaliar o estado de aglomeração das partículas em uma suspensão. Para suspensões com valor de potencial zeta igual a zero, que corresponde ao ponto isoelétrico, o tamanho de aglomerado atinge o seu valor máximo e diminui com o aumento do valor em módulo do potencial. Além do estudo de síntese de pós de óxido de níquel, Xiang et al. analisaram as condições de dispersão dos pós a partir dos dados do potencial zeta. Esses valores indicaram que o ponto isoelétrico do precipitado é 10,7 [65]. Com o decréscimo do pH da solução de 10,7 para 8,6, o potencial zeta aumenta de 0 para $19,2 \mathrm{mV}$ e o tamanho de aglomerados diminui de 66,5 para 40,2 nm. A análise do potencial zeta mostrou que a melhor condição de dispersão de pós de óxido de níquel ocorre para uma solução levemente alcalina $(\mathrm{pH}<9,0)$.

As concentrações de sólidos e de dispersante têm uma grande influência no comportamento reológico da suspensão. Geralmente, a ótima concentração de dispersante está correlacionada com a mínima viscosidade da suspensão. A quantidade otimizada de dispersante depende da carga superficial da partícula e do grupo fracional dissociado, bem como da carga do polímero. Esta medida reológica caracteriza o comportamento dos materiais submetidos à tensão de deformação. Em suspensões com baixa concentração 
de óxidos sólidos, entre 25 e $30 \%$ em volume, as suspensões apresentam propriedade newtoniana, ou seja, suas viscosidades permanecem constantes com a mudança na taxa de cisalhamento e as curvas são planas. No entanto, para suspensões com concentrações de sólido superior $47 \%$ em volume, as partículas passam a interagir entre si e o comportamento reológico das suspensões desvia do modelo newtoniano e as viscosidades diminuem com o aumento da taxa de cisalhamento, comportamento este conhecido como pseudoplástico, em reologia. A concentração de dispersante, em excesso na suspensão, pode provocar um aumento inesperado na viscosidade ou até mesmo uma leve floculação devido à dissolução do polímero no solvente [66].

Além da concentração de sólidos, parâmetros tais como tamanho de aglomerado e composição dos aditivos orgânicos são fatores que influenciam na microestrutura dos filmes finos obtidos pelo método de serigrafia. Analisando as imagens obtidas por MEV, Zhang et al observaram que os filmes de YSZ conformados com aglomerados grandes apresentaram microestrutura porosas [67]. A concentração ótima para obtenção de filmes densos com pós finos $(0,2 \mu \mathrm{m})$ ficou entre 30 e $45 \%$ em massa.

Tietz et al. analisaram o comportamento de sinterização do sistema NiO-YSZ, para aplicação como ânodo em célula de combustível, utilizando-se pós de óxido de níquel e de YSZ de procedência comercial [38]. Os parâmetros avaliados incluíram: forma e distribuição de tamanho das partículas e área superficial específica dos pós. Os resultados foram comparados com o material padrão desenvolvido no Centro de Pesquisa Jüllich, Alemanha. Os resultados demonstraram que amostras com pós finos de $\mathrm{NiO}(0,6-0,8 \mu \mathrm{m})$ apresentaram uma boa condutividade elétrica com alta porosidade enquanto pós de maior partículas $(5,6-14,7 \mu \mathrm{m})$ resultaram em baixa condutividade elétrica.

Quando os pós de YSZ são submetidos a uma pré-calcinação a área de superfície diminui com o aumento da temperatura devido à coalescência e sinterização de partículas menores. Para entender o efeito do tamanho de partícula no desempenho do anodo Ni-YSZ, pós de YSZ calcinados a 900, 1000 e $1200 \stackrel{\circ}{\circ}$ por 2 horas em ar foram misturados com pós de $\mathrm{NiO}(8-14 \mathrm{~nm})$ obtido pelo método de precipitação. Nestes estudos, a 
porosidade apropriada e melhor desempenho do ânodo foram obtidos para pós calcinados a $900^{\circ} \mathrm{C}$ [68]. Yu et al. analisaram o efeito do tamanho de partículas na microestrutura preparando compósitos de NiO-YSZ pela mistura de pós comerciais de NiO e YSZ com tamanho médio de partículas variando entre 1 e $10 \mu \mathrm{m}$ [69]. Os resultados mostram claramente que os pós finos formam a percolação e isolam as partículas maiores. Na mistura de pós maiores de $\mathrm{NiO}$ com pós finos de YSZ a propriedade mecânica é favorecida devido a percolação da fase cerâmica YSZ contudo, a propriedade elétrica é prejudicada fazendo com que o anodo seja relativamente resistivo. Por outro lado, quando pós finos de $\mathrm{NiO}$ são utilizados a propriedade elétrica é favorecida e a propriedade mecânica prejudicada devido ao isolamento das partículas maiores de YSZ. O uso de partículas finas de NiO e YSZ favorece a percolação das duas fases proporcionando ao anodo uma boa condutividade elétrica e mecânica.

Em outro estudo, Madsen et al. analisaram a influência da seqüência de adição dos pós no meio aquoso contendo aditivos orgânicos e também a influência do tamanho de partícula dos pós na sinterização [70]. Na mistura dos pós, quanto maior o tamanho de partículas de $\mathrm{NiO}$ maior a retração da amostra. Para uma mesma composição, a seqüência da adição de pós finos ou maiores de YSZ tem influência na densidade da amostras. A maior densidade das amostras foi obtida quando os pós finos e maiores de YSZ são misturados e homogeneizados antes da adição de pós de NiO. Isto ocorre devido à melhor distribuição espacial pelos pós finos de YSZ.

\section{III.2.4 - Método de síntese do compósito NiO-YSZ pela técnica de combustão}

Outra técnica que tem sido muito utilizada para preparação de pós de NiO-YSZ é a síntese por combustão, devido à possibilidade de produção de pós nanocristalinos, sem a introdução de nenhum produto intermediário e com alta pureza. Neste método, o grau de cristalização dos pós está diretamente relacionado com a temperatura de reação na qual o material de partida é exposto. Basicamente, a síntese de combustão faz uso da energia liberada na reação química de oxi-redução entre metais e não metais. $O$ processo é 
caracterizado por altas temperaturas, taxa de aquecimento rápida e reação em curto espaço de tempo. Dependendo da natureza dos reagentes: elementos ou compostos (sólido, líquido ou gás) e a energia liberada na reação, a síntese de combustão é descrita como síntese por Combustão Auto-Sustentada a Alta Temperatura (SHS - Self-Propagating High-Temperature Synthesis). Existem outras como síntese por Combustão a Baixa Temperatura (LCS - LowTemperature Combustion Synthesis); síntese por Combustão a partir de Soluções (SCS - Solution Combustion Synthesis); combustão de gel; combustão de sol-gel; combustão de emulsão; combustão de volume (explosão térmica), entre outros [71]. Dentre estes, a síntese por combustão a partir de soluções surgiu como uma excelente alternativa para produção de óxidos cerâmicos complexos, tais como aluminatos, ferritas e cromitos. Os produtos obtidos em escala nanométrica, com poucas impurezas e boa homogeneidade, podem ter diferentes aplicações avançadas. As vantagens desse processo sobre outros métodos de combustão são: possibilidade de maior controle sobre a homogeneidade e estequiometria dos produtos, incorporação de elementos desejáveis na matriz de óxidos e finalmente, simplicidade e rapidez de processo, sendo desnecessário o uso de equipamentos sofisticados. $O$ processo envolve a reação exotérmica entre um oxidante, geralmente $\mathrm{O}_{2}$, e um combustível orgânico na presença tais como nitratos metálicos, nitrato de amônio ou perclorato de amônio. Em particular, entre os sais, nitratos hidratados são os preferidos por causa de sua solubilidade em água quando requerido, que permite obter uma solução altamente homogênea, possuem nitrogênio em sua composição e fundem a uma temperatura relativamente baixa. Por sua vez, os combustíveis a serem usados podem ser classificados com base em sua estrutura química, isto é o tipo de grupo reativo, por exemplo, grupo amina, hidroxila ou carboxila, ligada a cadeia de hidrocarboneto etc [72 - 74]. Quando soluções aquosas de nitratos contendo os cátions de interesse são utilizadas como precursores na síntese por combustão de soluções, os combustíveis mais comumente utilizados são: uréia $\left(\mathrm{CH}_{4} \mathrm{~N}_{2} \mathrm{O}\right)$, carbohidrazina $\left(\mathrm{CH}_{6} \mathrm{~N}_{4} \mathrm{O}\right)$, ou glicina $\left(\mathrm{C}_{2} \mathrm{H}_{5} \mathrm{NO}_{2}\right)$. Todos eles também contêm em sua composição o nitrogênio, mas diferem no poder de redução e na quantidade de gases gerados, que afeta as características dos produtos de reação. A diferença no tamanho de partículas com o uso de diferentes 
combustíveis depende do número de moles de gases liberado durante a combustão. Quanto mais gases são liberados a desintegração é maior para não formar os aglomerados e mais calor é carregado do sistema, impedindo também o crescimento das partículas. A geração de gases cria regiões com micro e nanoporos, consequentemente são obtidos pós com alta área de superfície. Supondo uma combustão completa, a quantidade de gás liberado na reação de combustão com glicina, uréia e carbohidrazina é apresentada na Tab. 2 [75].

Tabela 2 - Quantidade de gás liberado após a combustão completa do combustível [75]

\begin{tabular}{crrcc}
\hline \hline Combustível & & Reação & $\begin{array}{c}\text { Gases gerados } \\
\text { (mol / mol de } \\
\text { combustível) }\end{array}$ \\
Uréia & $\mathrm{CH}_{4} \mathrm{~N}_{2} \mathrm{O}+3 / 2 \mathrm{O}_{2} \longrightarrow$ & $2 \mathrm{H}_{2} \mathrm{O}+\mathrm{CO}_{2}+\mathrm{N}_{2}$ & 4,0 \\
Glicina & $\mathrm{C}_{2} \mathrm{H}_{5} \mathrm{NO}_{2}+9 / 4 \mathrm{O}_{2} \longrightarrow$ & $5 / 2 \mathrm{H}_{2} \mathrm{O}+2 \mathrm{CO}_{2}+1 / 2 \mathrm{~N}_{2}$ & 5,0 \\
Carbohidrazina & $\mathrm{CH}_{6} \mathrm{~N}_{4} \mathrm{O}+2 \mathrm{O}_{2} \longrightarrow$ & $3 \mathrm{H}_{2} \mathrm{O}+\mathrm{CO}_{2}+2 \mathrm{~N}_{2}$ & 6,0 \\
\hline \hline
\end{tabular}

A reação não é isotérmica e quanto maior a quantidade de gases, mais calor é dissipado, e consequentemente não ocorre sinterização dos óxidos, uma vez que a temperatura não é tão elevada. Em reações com temperaturas mais altas os pós perdem as características de pós nanométricos.

Dentre os combustíveis, a uréia é a que apresenta o menor poder redutor, gerando também o menor volume de gases. Entretanto alguns fatores favorecem a escolha da uréia como combustível: é um produto facilmente encontrado, barato e gera menos calor em relação aos outros. [76]. Em reações de combustão, a quantidade de combustível é calculada pela estequiometria da reação entre sal de nitrato do elemento metálico e combustível, sendo expressa em termos de coeficiente estequiométrico dos elementos $\left(\Phi_{e}\right)$ que é um parâmetro usado para definir a mistura combustível - propelente / oxidante, como:

$\Sigma$ (coeficiente dos elementos oxidantes na fórmula específica) $\times$ (valência)

$\Phi_{\mathrm{e}}=\frac{\Sigma(\text { (coeficiente dos elementos redutores na fórmula específica) } \mathrm{x} \text { (valência) }}{(-1)}$ 
A mistura é estequiométrica quando $\Phi_{\mathrm{e}}=1$, pobre em combustível quando $\Phi_{\mathrm{e}}>1$, e rico em combustível quando $\Phi_{\mathrm{e}}<1$. Quando a mistura é estequiométrica, ocorre à combustão completa de todos os componentes da reação.

O uso de diferentes combustíveis proporciona diferentes temperaturas de chama de reação [61]. No caso da uréia, é adicionado o dobro da quantidade estequiométrica necessária para atingir uma temperatura de reação suficientemente alta para obter pós cristalinos [77]. Em outros tipos de síntese de combustão a reação é baseada em soluções de nitratos dos metais de interesse, alterando-se somente o tipo e a concentração de combustível [78 - 82].

Marinsek et al. utilizaram ácido cítrico como combustível e estudaram as diferentes relações molares de acido cítrico/sal de nitrato $(\mathrm{c} / \mathrm{n})$ onde o citrato é utilizado como combustível [61]. Observaram que a temperatura atinge o seu valor máximo na relação $\mathrm{c} / \mathrm{n}$ próxima ao valor estequiométrico, nestas condições o pó produzido apresenta tamanho nanométrico e uma concentração adequada de níquel para garantir uma percolação do metal. Na síntese por combustão proposta por Ringuedé et al., a uréia é o elemento combustível e o cálculo da quantidade estequiométrica do combustível foi baseado nas valências de oxidação e redução dos elementos [77]. Neste estudo, foi adicionado o dobro da quantidade estequiométrica de uréia necessária para atingir uma temperatura de reação suficientemente alta, e obtiveram pós nanocristalinos.

Shih et al. analisaram o efeito da temperatura de síntese no processamento de pós de NiO-YSZ, obtido pelo método de gel-combustão e empregou a termogravimetria para avaliar a evolução da decomposição térmica dos precursores até a conversão para NiO-YSZ [83]. Para caracterizar cada evento de decomposição foram empregadas técnicas complementares tais como espectroscopia de infravermelho, difração de raios $\mathrm{X}$, microscopia eletrônica de varredura e de transmissão, para identificar ligações químicas, mudanças de fases e morfologia. 
Mohebbi et al. realizaram a síntese de combustão do compósito NiOYSZ em fornos de microondas [84]. Observaram pós obtidos são mais homogêneos e menos densos, isto em função da reação ocorrer praticamente simultaneamente com o aumento do volume, pois a reação ocorre em segundos. Nos métodos convencionais as reações ocorrem após alguns minutos, pois a temperatura de ignição não é atingida imediatamente. Em um estudo da influência do pH na produção dos pós, Mohebbi et al concluíram que em pH menor que 7 a ignição é mais lenta do que em $\mathrm{pH}$ maior que 7 , isto ocorre porque a taxa de combustão diminui e mais gases são liberados e 0 tamanho de cristalitos diminui e a área de superfície especifica aumenta [85].

\section{III.3 - Microestrutura das cerâmicas de NiO-YSZ}

\section{III.3.1 - Cinética e mecanismo de sinterização}

Por definição, sinterização no estado sólido é o processo associado a altas temperaturas, no qual os pós conformados são transformados em um corpo sólido e denso através de transporte de massa por difusão, em escala atômica ou de vacância ao longo de uma superfície ou contorno de grão ou ainda através do volume do material. Os parâmetros que são envolvidos no processo são: composição química, distribuição do tamanho de partículas, poros, tempo, temperatura, taxa de aquecimento e atmosfera dinâmica de sinterização.

A força motriz de sinterização é a redução da energia livre total do sistema, $\Delta \mathrm{G}_{\mathrm{T}}$, do sistema:

$$
\Delta G_{T}=\Delta G_{v}+\Delta G_{b}+\Delta G_{T}+\Delta G_{s}
$$

Onde: $\Delta G_{v}, \Delta G_{b}$ e $\Delta G_{s}$ representam a variação de energia livre associadas ao volume, contorno de grão e área de superfície, respectivamente. [86].

Esta redução de energia é acompanhada por uma diminuição na área superficial total devido a dois mecanismos (difusão por contorno de grão e difusão por volume) que geralmente atuam no processo de sinterização: aumento no tamanho médio de partículas, formação dos pescoços e densificação, que é causado pela eliminação das interfaces sólido/vapor e pela formação de uma nova interface sólido/slido de menor energia. 
Para que a sinterização ocorra é necessário que a energia do contorno de grão $\left(\gamma_{C G}\right)$ seja duas vezes menor que a energia superficial da interface sólido/vapor ( $\left.\gamma_{S v}\right)$. A energia do contorno de grão é relacionada com a tensão superficial $\left(\gamma_{S v}\right)$ pela seguinte equação:

$$
\gamma_{\mathrm{CG}}=2 \gamma_{\mathrm{SV}} \operatorname{Cos}\left[\frac{\phi}{2}\right]
$$

Se $\gamma_{C G}$ e $\phi$ (ângulo diédrico) forem elevados, o pescoço cresce e cessa a eliminação dos poros. Isto provoca a formação de poros termodinamicamente estáveis que não podem ser removidos por tratamento térmico. Para muitos sistemas de óxidos os valores de $\gamma_{C G}$ e $\gamma_{S V}$ são próximos resultando em um ângulo diédrico $(\phi)$ de $120^{\circ}$.

Conceitualmente, a sinterização pode ser dividida em estágio inicial, intermediário e final. No estágio inicial, os contatos entre partículas são maximizados para formação dos pescoços. Nesta fase, as grandes diferenças nos raios ou curvatura provocam diferentes tensões na superfície do pescoço e contorno de grão, induzindo a diferentes concentrações de vacâncias. O fluxo de matéria vai da região de menor para maior vacância, isto é, da superfície convexa para a côncava. A retração linear neste estágio é de 3 a $5 \%$ que corresponde a uma densidade relativa de aproximadamente $65 \%$.

É no estágio intermediário que ficarão evidentes se os procedimentos adotados na preparação e conformação dos pós foram adequados para se atingir as propriedades e microestrutura desejadas no material sinterizado. $O$ empacotamento homogêneo favorece o mecanismo de difusão para formação do pescoço e formação dos contornos de grãos. As variações dimensionais aproximam os centros das partículas formando uma rede de poros cilíndricos interconectados que definirão a microestrutura. Na etapa final deste estágio a taxa de retração atinge seu valor máximo e os poros se tornam esféricos e isolados e a densidade atinge aproximadamente $90 \%$ da densidade teórica.

No estágio final, o posicionamento dos poros na microestrutura é o fator crítico na densificação do corpo cerâmico. O crescimento controlado dos grãos permite que os poros se alojem no contorno de grãos e sejam facilmente eliminados por difusão pela rede ou contorno de grão. Se, contudo, o crescimento dos grãos for rápido, pode ocorrer o aprisionamento dos poros 
dentro do grão, tornando difícil sua remoção, pois a eliminação é realizada apenas por difusão pela rede o que torna lenta prejudicando a densificação do material.

Marinsek et al. comprovaram que compósitos com diferentes composições químicas apresentam três estágios, sendo que todos apresentam uma retração elevada acima de $1000^{\circ} \mathrm{C}$, exceto o YSZ puro. Na faixa entre 1200 e 1250 `C é observado um decréscimo na taxa de redução do óxido de níquel e acima de $1300{ }^{\circ} \mathrm{C}$ a taxa de denficação dimi nui drasticamente [87]. Outra observação importante é que a sinterização de YSZ inicia a uma temperatura levemente inferior ao compósito NiO-YSZ. Contudo, NiO-YSZ densifica muito mais rápido em temperatura acima de $1100^{\circ} \mathrm{C}$ em comparação com a amostra YSZ. Como o processo de sinterização de materiais cerâmicos é muito complexo, o procedimento normalmente adotado é desenvolver modelos empíricos para estudo de cinética de sinterização a partir de dados obtidos em dilatômetro.

Um dos modelos utilizado para determinar a energia de ativação de retração é uma equação empírica derivada do modelo de estágio de sinterização combinado. Inicia-se com a equação de taxa de retração instantânea onde é analisada a contribuição da difusão por contorno de grão e por volume.

$$
-\frac{\mathrm{dL}}{\mathrm{Ldt}}=\frac{\gamma \Omega}{\mathrm{kT}} \cdot\left[\frac{\delta \mathrm{D}_{\mathrm{b}} \Gamma_{\mathrm{b}}}{\mathrm{G}^{4}}+\frac{\mathrm{D}_{\mathrm{v} \Gamma_{\mathrm{v}}}}{\mathrm{G}^{3}}\right]
$$

onde: $L$ é o comprimento da amostra, $\gamma$ é a área de superfície, $\Omega$ é o volume atômico, e $\delta$ é a espessura do contorno de grão, $\Gamma_{\mathrm{b}}$ e $\Gamma_{\mathrm{v}}$ definem a taxa de retração linear que será observada na microestrutura para uma dada escala, temperatura e parâmetros do material. G é o tamanho médio do grão, $k$ é a constante de Boltzmann, e T é a temperatura. $D_{b}$ e $D_{v}$ são os coeficientes de difusão por contorno de grão e por volume, respectivamente. Supondo que predomine apenas um mecanismo e $\Gamma$ e $G$ são independentes da densidade, ao transformar cada lado da equação (III.3.1.3) em logaritmo natural resultará na equação de Arrhenius, Eq. (III.3..4.), que pode ser usada para determinar a energia de ativação de densificação: 


$$
\ln \left(\frac{\mathrm{d}\left(\frac{\Delta \mathrm{L}}{\mathrm{L}_{0}}\right)}{\mathrm{dt}}\right) \cdot \mathrm{T}=\mathrm{A} \cdot\left(-\frac{\mathrm{nE}_{\mathrm{a}}}{\mathrm{RT}}\right)
$$

onde: $E_{a}$ é a energia de ativação de densificação e $n$ é uma constante que engloba todos os valores que descreve o comportamento de sinterização dos sólidos. A constante $n$ inclui informações da energia superficial, o volume atômico, espessura do contorno de grão e o coeficiente para difusão por contorno de grão e por volume.

Outra técnica que tem sido utilizada no estudo de cinética de sinterização de pós cerâmicos é o método quasi - isotérmico por passo, também conhecido como Stepwise Isothermal Dilatometry (SID) [88, 89]. Uma característica da técnica é que o aquecimento da amostra é controlado pela variação da retração da amostra $\left(\mathrm{dL}^{\mathrm{dt}} \mathrm{dt}^{-1}\right)$ em uma série de isotermas. Durante a isoterma, quando a retração da amostra atinge um valor mínimo, menor que o limite pré estabelecido a amostra é aquecida a uma taxa constante e o aquecimento suspenso quando o segundo limite pré estabelecido é excedido e novamente é estabelecida uma isoterma. Entre duas isotermas subseqüentes há um aquecimento em taxa constante. Para aplicação dos modelos cinéticos devem ser escolhidas aquelas isotermas que apresentem o comportamento mais linear possível.

Os dados obtidos nas isotermas são analisados para obter os parâmetros cinéticos de acordo com a equação empírica desenvolvida por Makipirtti-Meng:

$$
\frac{d Y}{d t}=n K(T) \cdot Y \cdot(1-Y) \cdot\left[\frac{(1-Y)}{Y}\right]^{\frac{1}{n}}
$$

onde: $\mathrm{Y}$ é a retração relativa durante $\mathrm{o}$ processo de sinterização, $\mathrm{n}$ é um parâmetro que define o mecanismo de sinterização e $k(T)$ um coeficiente que obedece a equação de Arrhenius. As energias de ativação para sinterização são determinadas pela equação: 


$$
\mathrm{K}(\mathrm{T})=A \cdot \exp \left(-\frac{\mathrm{Q}}{\mathrm{RT}}\right)
$$

onde: $\mathrm{Q}$ é a energia de ativação em J.mol ${ }^{-1}, \mathrm{~T}$ a temperatura em Kelvin, $\mathrm{R}$ a constante dos gases e A uma constante pré-exponencial

Individualmente, os componentes do compósito apresentam diferentes taxa de retração, sendo menores para YSZ em relação a NiO [90]. Quando o níquel metálico é usado para fabricação do compósito Ni-YSZ, a taxa de retração do Ni é menor do que a da YSZ, de forma que a variação na taxa de retração está diretamente ligada à concentração de Ni. Durante a sinterização um aumento na concentração de Ni resulta em um decréscimo na taxa de retração [91].

A temperatura de calcinação é que determina a mudança na distribuição do tamanho de partículas e área de superfície especifica, por sua vez, irá determinar a temperatura de sinterização. Como o YSZ não sofre alteração significativa no processo de calcinação dos pós é normalmente a fase $\mathrm{NiO}$ que é responsável pela variação nos valores de densidade a verde, tamanho de partículas e morfologia dos pós [92].

Amostra constituída de partículas pequenas são sinterizadas em temperaturas menores e o mecanismo ocorre em uma única etapa. Ao contrário, o mecanismo de sinterização das partículas maiores ocorrem em diversos estágios com diferentes taxa de retração em função da sinterização dos inter e/ou intra aglomerados [80]. No compósito, é a relação do tamanho de partículas entre $\mathrm{NiO}$ e YSZ que determinará a energia de ativação de sinterização. Quanto menor o valor dessa relação menor é a energia de ativação de sinterização. No compósito a maior energia de ativação está relacionada à maior contribuição do YSZ no processo de sinterização. A adição de partículas nanométricas de $\mathrm{NiO}$ reduz a energia de ativação de sinterização do NiO-YSZ por cerca de 100 kJ.mol ${ }^{-1}$.

Marinsek et al. apresentaram um estudo da sinterabilidade dos pós, com diferentes composições químicas [61]. Observaram que quanto maior a quantidade de $\mathrm{NiO}$ maior é a densidade da amostra após o tratamento térmico. Em uma comparação da taxa de retração relativa, notaram que o aumento da quantidade de $\mathrm{NiO}$ no material compósito determina o grau de retração da 
amostra. Observaram também que as formações de aglomerados de menor tamanho resultam em regiões com um menor domínio de uma única fase, onde apenas a fase $\mathrm{NiO}$ ou YSZ está presente. A relação entre a continuidade da fase de níquel através de toda amostra e sua alta condutividade elétrica foi explicada pela teoria da percolação. A condutividade torna-se eletrônica com uma concentração de Ni metálico superior a $35 \%$ em volume.

A sinterização da $Y S Z$ inicia-se a uma temperatura próxima a $1000{ }^{\circ} \mathrm{C}$, ligeiramente inferior à temperatura do NiO-YSZ. Contudo, a densificação do compósito NiO-YSZ é muito mais rápida do que a da YSZ, ocorrendo em temperatura superior a $1100^{\circ} \mathrm{C}$. Conseqüentemente, precursores com um alto teor de $\mathrm{NiO}$ atingem densidades muito maiores depois do tratamento térmico. Em temperaturas superiores a $1300{ }^{\circ} \mathrm{C}$, a taxa de densificação diminui drasticamente [93].

Em um estudo de sinterabilidade em função da temperatura, Fukui et al. observaram que quando a temperatura de sinterização atinge $1350{ }^{\circ} \mathrm{C}$, o compósito NiO-YSZ apresenta microestrutura adequada, na qual grãos pequenos de YSZ são uniformemente dispersados sobre a superfície de grãos de $\mathrm{Ni}$, proporcionando uma percolação da fase metálica [94]. Para uma temperatura de sinterização superior a $1350{ }^{\circ} \mathrm{C}$ começa a ocorrer uma diminuição na região da tripla fase reacional devido ao crescimento dos grãos $\mathrm{NiO}$ e YSZ. O limite de solubilidade do $\mathrm{NiO}$ em YSZ tem um efeito significativo na estabilização da fase cúbica de YSZ e na propriedade elétrica. O limite de solubilidade de $\mathrm{NiO}$ no YSZ é de aproximadamente 2 mol\%. Nestas condições, o tamanho do grão de YSZ na estrutura cerâmica sinterizada a $1600^{\circ} \mathrm{C}$ atinge o seu tamanho máximo. Para concentrações acima de 2 mol\% o NiO surge como grão intergranular, formando uma segunda fase, retardando 0 crescimento do grão de YSZ. Em uma composição de $60 \mathrm{~mol} \%$ de NiO, o tamanho dos grãos de NiO e YSZ é da mesma ordem de grandeza. Pela análise das micrografias (MEV) observou-se que na região das duas fases dos compósitos, o tamanho dos grãos da fase $\mathrm{NiO}$ e YSZ diminui com o aumento da concentração de uma das fases. As medidas de condutividade, em temperaturas de 800 a $1000{ }^{\circ} \mathrm{C}$, das amostras sinterizadas a $1600{ }^{\circ} \mathrm{C}$ por 4 horas, mostram que até $40 \mathrm{~mol} \%$ de NiO em YSZ as cerâmicas são condutoras 
iônicas, para o intervalo entre $40 \mathrm{~mol} \%$ e $80 \mathrm{~mol} \%$ de NiO as cerâmicas são condutores mistos (eletrônico-iônico) e para concentrações acima de 80 mol\% são condutores eletrônicos [95, 96].

Uma análise quantitativa da microestrutura e sua relação com a concentração de $\mathrm{NiO}(10-70 \%$ em volume) foi apresentado por Lee et al.. Neste estudo observou-se que o tamanho dos poros aumenta com o aumento da concentração de $\mathrm{NiO}$ [97]. Este fato foi justificado pelo maior crescimento dos grãos de $\mathrm{NiO}$ durante a sinterização e a necessidade de extrair mais oxigênio durante a redução. De uma maneira geral, observou-se que o crescimento dos grãos de YSZ ocorre durante o processo de sinterização, enquanto que no caso do $\mathrm{Ni}$, além do crescimento durante a sinterização a $1400^{\circ} \mathrm{C}$, ocorre um aumento adicional durante a redução. As interfaces Ni-poro apresentaram-se em maior número devido à coalescência das partículas de $\mathrm{Ni}$ que ocorrem preferencialmente em direção aos poros.

As mudanças na microestrutura e desempenho eletroquímico, em função da variação do volume fracional de partículas finas e maiores de $\mathrm{NiO}$ e YSZ, na preparação do compósito foram estudadas para um volume fracional de níquel fixado em $45 \%$. Os resultados demonstraram que a melhor condição para obtenção de uma cerâmica, com estrutura homogênea e rica em sítios da fase tripla reacional para reação no eletrodo e com a melhor atividade anódica, é para uma mistura de pós de NiO e YSZ com tamanho de partículas similares. [98].

\section{III.4 - Redução do NiO pelo hidrogênio}

Geralmente o anodo poroso $\mathrm{Ni}-$ YSZ é fabricado a partir de pós de $\mathrm{NiO}$ e YSZ e então co-sinterizados com o eletrólito e catodo. Quando o gás combustível hidrogênio é alimentado pela primeira vez o NiO - YSZ é convertido em Ni - YSZ e como resultado da redução, alteram-se significativamente a massa, o volume e a porosidade do compósito, assim como suas propriedades mecânicas e físicas. A redução do níquel provoca mudança microestrutural que pode determinar o tipo, tamanho e distribuição dos defeitos. 
Para que o compósito NiO-YSZ seja utilizado como anodo é necessário que a cerâmica apresente uma porosidade acima de $30 \%$ em volume para permitir o fluxo de gases e saída dos produtos de reação. Considerando-se que após a redução do $\mathrm{NiO}$ para $\mathrm{Ni}$ cerca de $41,6 \%$ do volume inicial de $\mathrm{NiO}$ é transferido para o poro, esta alteração no volume é conseqüência da variação molar entre o volume do níquel metálico e do óxido de níquel, que ocorre segundo a relação indicada na Eq. (III.4.1)

$$
\Delta \mathrm{V}=\left(\frac{\mathrm{V}_{\mathrm{Ni}}-\mathrm{V}_{\mathrm{NiO}}}{\mathrm{V}_{\mathrm{NiO}}}\right) \times 100=41,6 \%
$$

Os dados do volume molar do óxido de níquel e níquel metálico são apresentados abaixo na Tab. 03 [99].

Tabela 3 - Dados para o cálculo do volume molar do óxido de níquel e níquel metálico

\begin{tabular}{lcc}
\hline \hline & $\mathrm{NiO}$ & $\mathrm{Ni}$ \\
\hline $\mathrm{M}\left(\mathrm{g} \cdot \mathrm{mol}^{-1}\right)$ & 74,71 & 58,71 \\
$\rho\left(\mathrm{g} \cdot \mathrm{cm}^{-3}\right)$ & 6,6 & 8,9 \\
$\mathrm{~V}\left(\mathrm{~cm}^{3} \cdot \mathrm{mol}^{-1}\right)$ & 11,32 & 6,60 \\
\hline
\end{tabular}

Para obter uma porosidade final entre 35 e $42 \%$ é necessário que o compósito apresente uma porosidade inicial entre 10 e $20 \%$ antes da redução do óxido de níquel para níquel metálico e um volume fracional de níquel entre 40 e $70 \%$ [97].

A porosidade aparente após a redução depende apenas da fração reduzida e não do método adotado para redução. Quando este aumento na porosidade é apenas função da retração do volume de $\mathrm{NiO}$ para $\mathrm{Ni}$, a porosidade pode ser expressa em função da fração reduzida de $\mathrm{NiO}$ conforme a Eq. (III.4.2)

$$
\mathrm{P}=\mathrm{P}_{0}+\rho_{0}^{0} \mathrm{~m}_{\mathrm{NiO}}\left[\frac{1}{\rho_{\mathrm{NiO}}}-\frac{1}{\rho_{\mathrm{Ni}}}+\frac{\mathrm{m}_{\mathrm{O}}}{\mathrm{m}_{\mathrm{NiO}}} \frac{1}{\rho_{\mathrm{Ni}}}\right] \mathrm{R}
$$


onde $\mathrm{P}, \mathrm{P}_{0}, \rho_{0}, \rho_{\mathrm{Ni}}, \rho_{\mathrm{NiO}}, m_{N i O}^{0}, \mathrm{~m}_{\mathrm{O}}, \mathrm{m}_{\mathrm{NiO}}$ e $\mathrm{R}$ são porosidade, porosidade inicial, densidade inicial da amostra, densidade do níquel, densidade do óxido de níquel, massa fracional inicial de $\mathrm{NiO}$, massa molecular de oxigênio e $\mathrm{NiO}$ e fração de óxido de níquel reduzido, respectivamente [100].

A porosidade relativa da amostra reduzida é normalmente determinada conforme a norma ASTM C20-00.

Como YSZ não sofre redução a $800^{\circ} \mathrm{C}$, a variação de massa que ocorre durante o processo de redução é resultado apenas da conversão do $\mathrm{NiO}$ para Ni. A variação de massa, $\Delta \mathrm{m}$, em função do tempo é a diferença entre a massa inicial da amostra antes da redução e a massa da amostra depois da redução. A fração de NiO reduzido pode ser expresso pela Eq.(III.4.3) [101]:

$$
\mathrm{R}=\frac{\Delta \mathrm{m} \cdot\left[\frac{\mathrm{m}_{\mathrm{NiO}}}{\mathrm{m}_{\mathrm{O}}}\right]}{\mathrm{C}_{\mathrm{NiO}}}
$$

Onde: $\mathrm{C}_{\mathrm{NiO}}$ é a porcentagem em peso de $\mathrm{NiO}$ no compósito $\mathrm{NiO}-\mathrm{YSZ}, \mathrm{m}_{\mathrm{NiO}} \mathrm{e}$ mo são a massa molar de $\mathrm{NiO}$ (74,7 u.m.a.) e oxigênio (16 u.m.a.),respectivamente.

A redução do óxido de níquel ocorre segundo a reação:

$$
\mathrm{NiO}_{(\mathrm{s})}+\mathrm{H}_{2(\mathrm{~g})} \rightarrow \mathrm{Ni}_{(\mathrm{s})}+\mathrm{H}_{2} \mathrm{O}_{(\mathrm{g})}
$$

A redução de $\mathrm{NiO}$ no compósito NiO-YSZ apresenta uma cinética de reação de primeira ordem com dois estágios bem definidos. No primeiro estágio a cinética de redução é linear e muito rápida, o segundo estágio apresenta uma taxa de redução mais lenta e diminui continuamente até que toda fração de $\mathrm{Ni}^{0}$ chegue a $100 \%$. As pesquisas indicam que a cinética de redução no primeiro estágio é controlada pela taxa de reação química que ocorre na superfície do óxido, isto é o hidrogênio é adsorvido na superfície e reage com o óxido. Depois de terminada a reação na superfície, a frente da reação avança em direção ao interior dos aglomerados e a taxa de redução neste segundo estágio passa ser controlada pela difusão do gás na superfície a velocidade de reação diminui drasticamente devido à formação de cristalito de 
níquel na superfície dos óxidos [101]. Em um estudo realizado por difração de raio $X$, utilizando o refinamento (método Rietveld), Rojas et al. analisaram o processo cinético de redução, pela associação da transformação de NiO para $\mathrm{Ni}^{0}$ [102]. Observaram que o volume da célula unitária de YSZ permanece inalterado durante o processo de redução, enquanto no caso do níquel ocorre um decréscimo no volume da célula com estrutura cúbica em função do tempo.

Jeangros et al., baseado no trabalho de Bonvalot-Dubois, propuseram que duas reações separadas podem ser usada para descrever a transferência dos íons oxigênio do $\mathrm{NiO}$ para YSZ e subsequentemente a desorção da água. Para parte interna da interface YSZ/NiO, a reação ocorre conforme a Eq. (III.4.5)

$$
\mathrm{O}_{0}^{\prime \prime}(\mathrm{NiO})+\mathrm{V}_{0}(\mathrm{YSZ}) \rightarrow \mathrm{O}_{0}^{\prime \prime}(\mathrm{YSZ})+\mathrm{V}_{0}(\mathrm{NiO})
$$

onde $O_{o}(\mathrm{NiO})$ é um íon oxigênio de $\mathrm{NiO}, V_{o}$ (YSZ) é uma vacância de oxigênio em YSZ, $O_{o}(Y S Z)$ é um íon oxigênio no $\mathrm{YSZ}$ e $V_{o}^{\prime \prime}(\mathrm{NiO})$ é uma vacância de oxigênio em NiO. Subsequentemente para a interface $\mathrm{NiO} / \mathrm{YSZ} / g a ́ s$, a equação segue a Eq. (III.4.6) [103].

$$
\mathrm{H}_{2}+\mathrm{O}_{0}^{\prime \prime}(\mathrm{YSZ}) \rightarrow \mathrm{H}_{2} \mathrm{O}+\mathrm{V}_{0}^{\prime \prime}(\mathrm{YSZ})+2 e^{-}(\mathrm{NiO})
$$

A criação de vacância de oxigênio na superfície do NiO ativa outro mecanismo: a adsorção de $\mathrm{H}_{2}$ nos átomos de $\mathrm{Ni}$ adjacentes a vacância de oxigênio.

Quanto ao comportamento da zircônia $\left(\mathrm{ZrO}_{2}\right)$ em atmosfera redutora, existem inúmeros estudos e de acordo com estes relatos, a zircônia pode ser reduzida parcialmente em altas temperaturas, geralmente acima de $500 \cong \mathrm{C}$, e que esta redução ocorre apenas nas camadas superficiais [104,105]. No caso da zircônia estabilizada, Dow et al. comprovaram que o consumo de hidrogênio é de aproximadamente $10 \times 10^{-6} \mathrm{~mol}$ para uma amostra de 0,2 gramas, confirmando que o YSZ não é facilmente reduzido [106].

Além da mudança na composição química do anodo durante a redução, a porosidade criada também provoca um efeito significativo na microestrutura e nas propriedades mecânicas do material. O módulo de elasticidade diminui com a formação de porosidade e a tenacidade à fratura aumenta após a 
redução devido à formação de uma fase dúctil de níquel metálico. A resistência da amostra Ni-YSZ diminui com o aumento da porosidade mais rapidamente que o módulo elástico e tenacidade à fratura, provavelmente devido ao fato de que a distribuição crítica dos defeitos é uma função da porosidade [107].

A diferença entre o tamanho de partículas do níquel e tamanho e distribuição dos poros afeta significativamente o comportamento de expansão volumétrica do anodo. Por análise termomecânica é possível observar que anodos fabricados a partir de pós com tamanho de partículas maiores de $\mathrm{NiO}$ não sofrem expansão ou fraturas quando da reoxidação, devido à capacidade de acomodação dos poros durante a expansão de volumétrica. No caso de anodos fabricados a partir de pós finos de $\mathrm{NiO}$ os poros não são suficientes para absorverem a expansão de volume e ocorre a fratura. Por termogravimetria é possível analisar qual a influência do tamanho de partículas de NiO na cinética de redução, em função da porosidade formada durante o processo [108].

Outro método utilizado para estudar a redução do $\mathrm{NiO}$ para $\mathrm{Ni}^{0}$ consiste na análise da redução "in situ" por difração de raios $X$. Esta técnica permite a medida simultânea da cinética de redução. Outra característica desta técnica é a possibilidade de estudar a redução com temperatura programada (TPR), isto é determinar a temperatura mínima para que a redução comece a ocorrer [102].

Em experimentos realizados por análise termogravimétrica, à taxa constante de aquecimento, pressão atmosférica e em elevadas temperaturas $\left(25-600{ }^{\circ} \mathrm{C}\right.$ ), observou-se que a redução do $\mathrm{NiO}$ começa a ocorrer somente após um período de indução, faixa de temperatura em que o consumo de $\mathrm{H}_{2}$ é observado. Os dados obtidos em condições isotérmicas demonstram que existe um período de indução para redução do $\mathrm{NiO}$ e que a duração deste tempo diminui com o aumento da temperatura, até que em temperatura superior a $310^{\circ} \mathrm{C}$ este fenômeno não é mais observado. Durante esse período de indução, são criados defeitos na superfície do $\mathrm{NiO}$ que são sítios ativos para uma alta eficiência para dissociação do $\mathrm{H}_{2}$ e remoção do oxigênio do sistema. [109] 
O estudo da interação entre $\mathrm{NiO}$ e YSZ, apresentado por Mori et al., indica que quanto menor a fração de $\mathrm{NiO}$ maior é o contato entre NiO e YSZ. Pelo método da redução com temperatura programada, para temperaturas entre 900 e $1300 \mathrm{~K}$ o processo de redução envolve uma lenta transferência de massa no sólido [32]. Entre 700 e $900 \mathrm{~K}$ nota-se dois picos distintos, indicando que para maior interação entre $\mathrm{NiO}$ e $\mathrm{YSZ}$ a redução ocorre em temperaturas maiores.

A porosidade que permanece no corpo cerâmico após a redução pode não ser suficiente para permitir uma percolação adequada quando são utilizadas partículas finas $(<1 \mu \mathrm{m})$ na formação do anodo. Neste caso, normalmente são adicionados formadores de poros que decompõem em forma de gases durante o tratamento térmico. Haslam et al. apresentaram um estudo da influência dos formadores de poros na difusão do gás hidrogênio na cinética de redução do NiO para níquel metálico [110] . Neste estudo, uma adição de $30 \%$ em massa de amido de arroz foi considerada excessiva, pois diminuiu a eficiência da célula. A composição ideal foi $20 \%$ em massa de formador de poros na composição inicial dos precursores. 


\section{IV - PROCEDIMENTO EXPERIMENTAL}

\section{IV.1 - Matérias-primas de partida}

As matérias -primas empregadas na preparação do compósito NiO-YSZ foram listadas abaixo na Tab. 4 de acordo com o método de preparação.

Tabela 4 - Matérias-primas empregadas na preparação do compósito NiO-YSZ

\begin{tabular}{|c|c|c|c|}
\hline Matéria Prima & Procedência & Aplicação direta & $\%$ \\
\hline \multirow[t]{2}{*}{$\mathrm{ZrOCl}_{2}$} & IPEN & Coprecipitação & 99,5 \\
\hline & & Mistura de pós & \\
\hline \multirow[t]{2}{*}{$\mathrm{Y}_{2} \mathrm{O}_{3}$} & Aldrich Chemical & Coprecipitação & 99,99 \\
\hline & & Mistura de pós & \\
\hline $\mathrm{NiCl}_{2} \cdot 6 \mathrm{H}_{2} \mathrm{O}$ & Merck & Coprecipitação & 98 \\
\hline $\mathrm{Ni}\left(\mathrm{NO}_{3}\right)_{2} \cdot 6 \mathrm{H}_{2} \mathrm{O}$ & Aldrich Chemical & Combustão & \\
\hline $\mathrm{ZrO}\left(\mathrm{NO}_{3}\right)_{2} \cdot \mathrm{xH}_{2} \mathrm{O}$ & Aldrich Chemical & Combustão & 97 \\
\hline $\mathrm{Y}\left(\mathrm{NO}_{3}\right)_{3} \cdot 6 \mathrm{H}_{2} \mathrm{O}$ & Aldrich Chemical & Combustão & 99,9 \\
\hline $\mathrm{NiO}$ & Merck & Mistura de pós & 97 \\
\hline
\end{tabular}

Os demais reagentes utilizados, tais como, hidróxido de amônio, uréia, defloculantes, dispersantes, álcool etílico e butanol foram todos de grau analítico.

\section{IV.2 - Preparação de pós precursores}

A preparação de pós de $\mathrm{NiO}$ - 8,5 YSZ (zircônia estabilizada com 8,5 mol\% ítria) foi realizada empregando-se os processos de coprecipitação, combustão e mistura mecânica dos pós. A otimização dos parâmetros tem como objetivo obter um compósito que apresente uma composição final em massa entre YSZ e NiO de $42: 58 \%$ respectivamente, que corresponde a um volume final de $40 \%$ de níquel, conforme recomendado na literatura para aplicações deste material como anodo de uma SOFC [13].

Para atingir este objetivo foram realizados estudos onde foram alterados diversos parâmetros e composições para entender o comportamento dos processos de sínteses e mistura de pós, conforme descritos nos itens a seguir. 


\section{IV.2.1 - Síntese dos pós}

\section{IV.2.1.1 - Síntese por coprecipitação}

Para estudar a influência do $\mathrm{pH}$ na precipitação do $\mathrm{Ni}(\mathrm{OH})_{2}$ (Fig. 5), preparou-se uma solução aquosa de $\mathrm{NiCl}_{2}$ com concentração de $\mathrm{Ni}^{2+}$ fixada em $0,1 \mathrm{~mol} \cdot \mathrm{L}^{-1}$. Em um béquer contendo uma alíquota desta solução, sob agitação mecânica, adicionou-se um volume fixo de solução aquosa de $\mathrm{NH}_{4} \mathrm{OH}$ com concentração variando entre 0,1 e 6,0 mol.L ${ }^{-1}$. Para cada concentração de $\mathrm{NH}_{4} \mathrm{OH}$ mediu-se o $\mathrm{pH}$ da solução a temperatura ambiente. A precipitação do $\mathrm{Ni}(\mathrm{OH})_{2}$ foi realizada adicionando-se uma alíquota da solução $\mathrm{NiCl}_{2}$ e cloreto de níquel, aquecida a $98{ }^{\circ} \mathrm{C}$, em um béquer contendo hidróxido de amônio $\left(0,1-6,0\right.$ mol. $\left.\mathrm{L}^{-1}\right)$ sob vigorosa agitação. Ao término da adição de $\mathrm{NH}_{4} \mathrm{OH}$ na solução aquosa de $\mathrm{NiCl}_{2}$ foi dobrado o volume final do sobrenadante com água destilada. A suspensão resultante foi aquecida a $98{ }^{\circ} \mathrm{C}$ com agitação contínua, resfriada à temperatura ambiente e mantida sem agitação. Após 24 horas mediu-se novamente $\mathrm{o} \mathrm{pH}$ e uma alíquota foi retirada para determinar a concentração de níquel no sobrenadante por espectrometria de emissão atômica com fonte de plasma de argônio induzido (ICP-AES). O rendimento da precipitação do $\mathrm{Ni}(\mathrm{OH})_{2}$ foi determinado pela diferença de massa de $\mathrm{Ni}^{2+}$ na solução precursora e massa de $\mathrm{Ni}^{2+}$ não precipitado presente no sobrenadante.

Adotando o mesmo procedimento descrito acima, foi estudado o efeito da concentração de $\mathrm{Ni}^{2+}$ no rendimento da precipitação. Para este estudo, foram preparadas soluções aquosas de $\mathrm{NiCl}_{2}$ com concentração de níquel variando entre 0,01 e 0,2 mol. $\mathrm{L}^{-1}$ fixando-se $\circ \mathrm{pH}$ inicial do $\mathrm{NH}_{4} \mathrm{OH}$ em 9,5. 


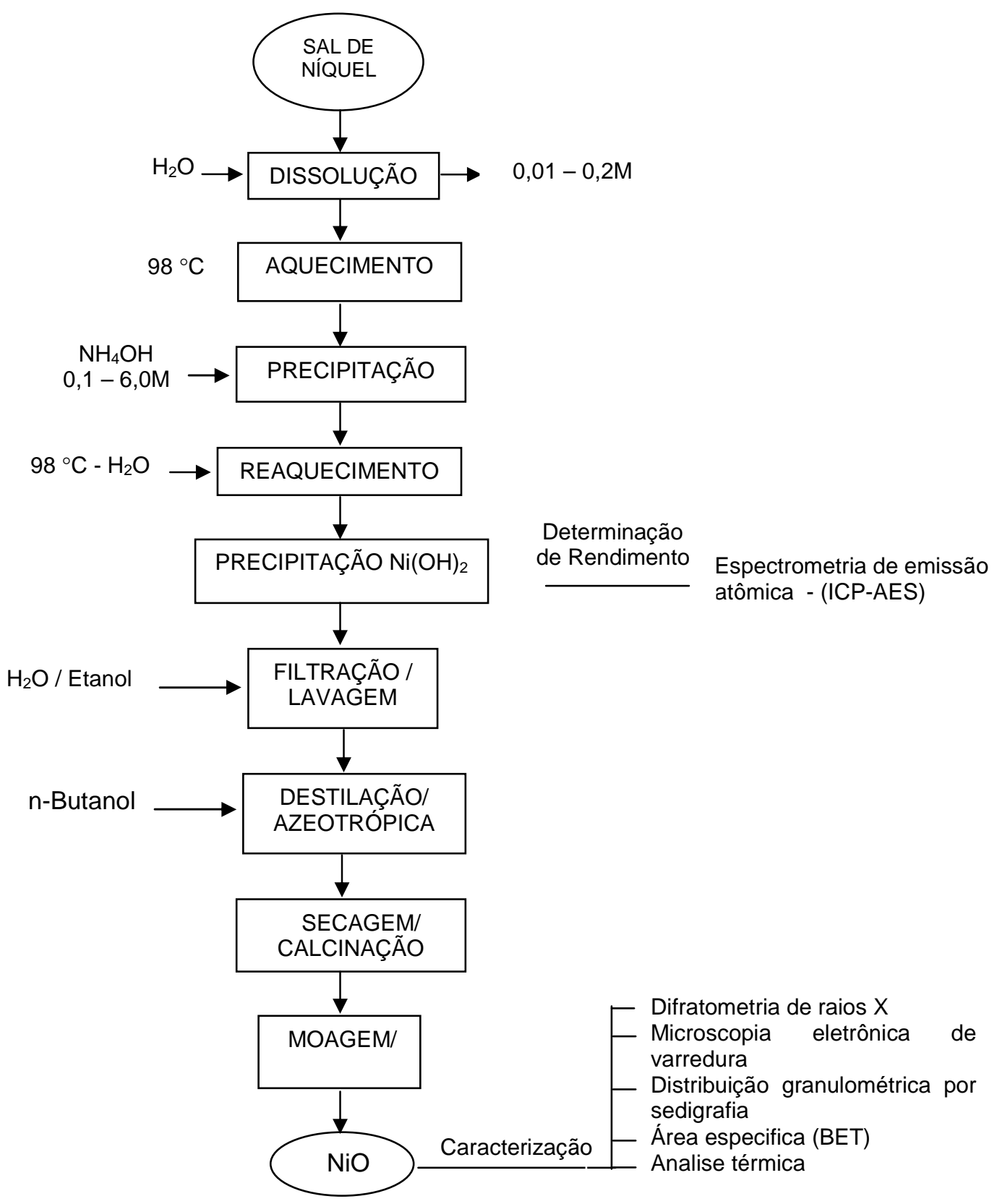

Figura 5 - Diagrama esquemático do processo de síntese de $\mathrm{NiO}$ 
Adotando-se o procedimento definido nos experimentos anteriores, foram adotadas as seguintes condições para avaliação do rendimento de precipitação do cátion níquel na presença dos cátions $\mathrm{Zr}^{4+}$ e $\mathrm{Y}^{3+}$ (Fig. 6): [ $\left.\mathrm{Ni}^{2+}\right]$ $=0,1 \mathrm{~mol} / \mathrm{L} ; 29 \leq(\mathrm{NiO})_{Y S Z} \leq 79 \%$ em massa; $\left(\mathrm{Y}_{2} \mathrm{O}_{3}\right)=8,5 \mathrm{~mol} \%$ em relação a zircônia.

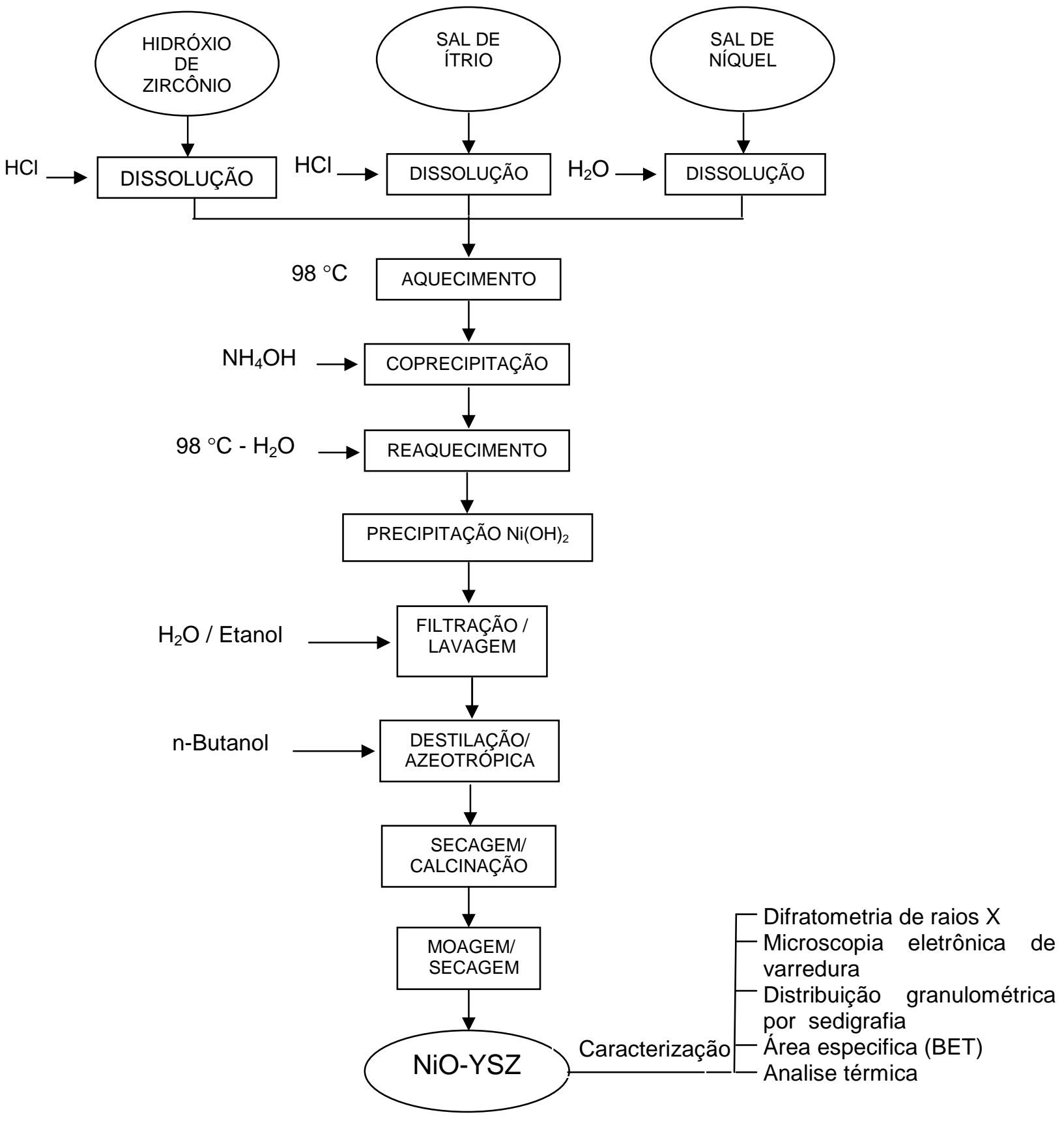

Figura 6 - Diagrama esquemático do processo de síntese por coprecipitaçãa do compósito NiO-YSZ 
A reação foi iniciada pela introdução dos precursores, previamente aquecidos a $98{ }^{\circ} \mathrm{C}$, por nebulização e em seguida fez se a adição de uma solução aquosa de $\mathrm{NH}_{4} \mathrm{OH} 4,0 \mathrm{~mol} . \mathrm{L}^{-1}$, sob vigorosa agitação. Ao término da precipitação, adicionou-se água destilada de modo a dobrar o volume da solução. A suspensão resultante foi reaquecida a $98^{\circ} \mathrm{C}$ com agitação contínua, resfriada à temperatura ambiente e mantida em repouso por 24 horas. Após este período foi retirada uma alíquota do sobrenadante para determinar a concentração de $\mathrm{Ni}^{2+}$.

A suspensão foi então filtrada a vácuo e o retido no filtro, lavado com água destilada para remoção dos íons cloreto (teste executado com $\mathrm{Ag}^{+} / \mathrm{HNO}_{3}$ ). Para evitar a formação de aglomerados fortes, os precipitados foram lavados com álcool etílico e submetidos a uma destilação azeotrópica com n-butanol. A destilação, que tem como objetivo remover a água residual inicia-se a $92,25^{\circ} \mathrm{C}$, quando ocorre a formação da mistura azeotrópica n-butanol - água. A água é totalmente removida do precipitado antes que todo solvente seja evaporado, pois o ponto de ebulição do butanol é $117,5^{\circ} \mathrm{C}$. Os pós resultantes foram secos em estufa a $80^{\circ} \mathrm{C}$ por 24 horas, calcinados a $800^{\circ} \mathrm{C}$ por 1 hora e submetidos à moagem em etanol por 15 horas, em moinho de bolas com meio de moagem de zircônia e novamente seco em estufa a $80^{\circ} \mathrm{C}$ por 8 horas.

\section{IV.2.1.2 - Síntese por combustão}

Na síntese por combustão (Fig. 7) os pós de NiO-YSZ foram obtidos a partir da mistura de sais de nitrato, dissolvidos em água, juntamente com a uréia, de maneira a obter uma relação em porcentagem de massa entre $\mathrm{NiO}$ e 8,5 YSZ de 56:44 e aquecidos em uma manta aquecedora. A relação entre o combustível e sais de nitrato foram controladas de acordo com o balanço entre a valência do oxidante e redutor [111].

A solução contendo os íons metálicos foi submetida a aquecimento em manta até a temperatura de $400^{\circ} \mathrm{C}$, medida com termopar. Neste estágio praticamente todo líquido é eliminado e com o continuo aquecimento, são formados flocos finos, que se expandem com a rápida liberação de um grande 
volume de gases. A partir deste ponto ocorre a combustão, formando-se aglomerados porosos. A quantidade de combustível correspondeu ao valor estequiométrico, 100, 150, 175 e 200\% de excesso com base na relação estequiométrica, conforme as seguintes reações:

$$
\begin{aligned}
& 10 \mathrm{CO}\left(\mathrm{NH}_{2}\right)_{2}+6 \mathrm{Ni}\left(\mathrm{NO}_{3}\right)_{2} 6 \mathrm{H}_{2} \mathrm{O} \longrightarrow 6 \mathrm{NiO}+16 \mathrm{~N}_{2}+10 \mathrm{CO}_{2}+56 \mathrm{H}_{2} \mathrm{O} \\
& 15 \mathrm{CO}\left(\mathrm{NH}_{2}\right)_{2}+6 \mathrm{Y}\left(\mathrm{NO}_{3}\right)_{3} 6 \mathrm{H}_{2} \mathrm{O} \longrightarrow 3 \mathrm{Y}_{2} \mathrm{O}_{3}+24 \mathrm{~N}_{2}+15 \mathrm{CO}_{2}+36 \mathrm{H}_{2} \mathrm{O} \text { (IV.4.2.1.2) } \\
& 10 \mathrm{CO}\left(\mathrm{NH}_{2}\right)_{2}+6 \mathrm{Zr}\left(\mathrm{NO}_{3}\right)_{2} \mathrm{nH}_{2} \mathrm{O} \longrightarrow 6 \mathrm{ZrO}_{2}+16 \mathrm{~N}_{2}+10 \mathrm{CO}_{2}+\mathrm{nH}_{2} \mathrm{O} \quad \text { (IV.4.2.1.3) }
\end{aligned}
$$

As temperaturas de reação foram medidas com pirômetro ótico.

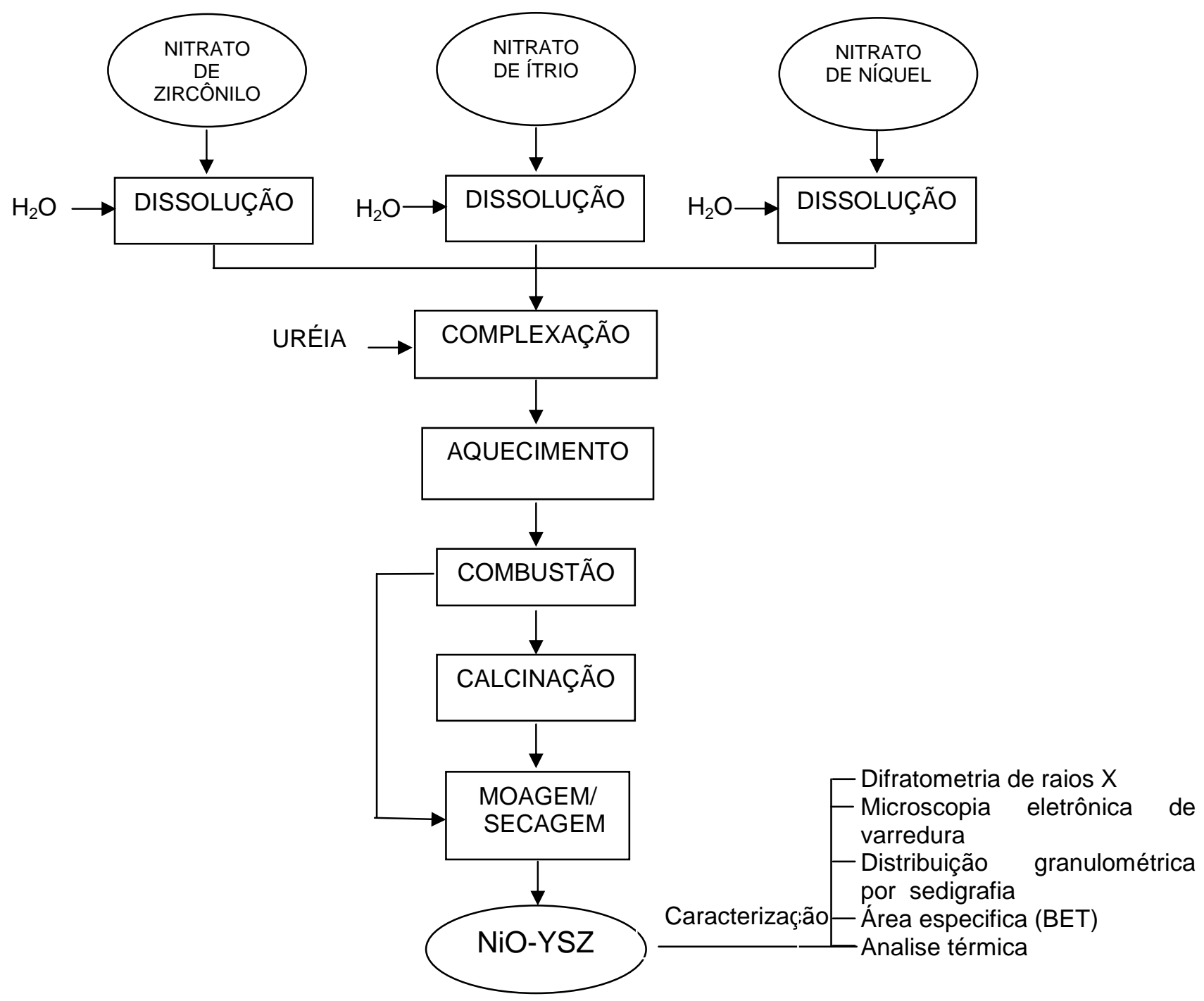

Figura 7 - Diagrama esquemático do processo de síntese por combustão do compósito NIO-YSZ 
As amostras foram codificadas como CONYSZ mais um valor numérico, sendo este valor correspondente ao excesso de combustível utilizado na síntese, conforme Tab. 5.

Tabela 5 - Relação de amostras com as respectivas quantidades de combustível adicionado em excesso

\begin{tabular}{ccc}
\hline \hline Amostra & $\begin{array}{c}\text { Excesso de } \\
\text { uréia (\%) }\end{array}$ & $\Phi_{\mathrm{e}}$ \\
\hline \hline CONYZ & Estequiométrico & 1,0 \\
\hline CONYZ1,0 & 100 & 0,65 \\
\hline \hline CONYZ1,5 & 150 & 0,57 \\
\hline \hline CONYSZ 1,75 & 175 & 0,55 \\
\hline \hline
\end{tabular}

Em reações de combustão, a quantidade de combustível é calculada pela estequiometria da reação entre o nitrato metálico e combustível, sendo expressa em termos de coeficiente estequiométrico dos elementos $\left(\Phi_{\mathrm{e}}\right)$ que é um parâmetro usado para descrever a mistura combustível - propelente / oxidante, definido como:

$$
\Phi_{\mathrm{e}}=\frac{\sum \text { (coeficiente dos elementos oxidantes na fórmula específica) } \times \text { (valência) }}{(-1) \Sigma \text { (coeficiente dos elementos redutores na formula especifica) } \times \text { (valência) }}
$$

A mistura é estequiométrica quando $\Phi_{\mathrm{e}}$ é igual a 1 , pobre em combustível quando $\Phi_{\mathrm{e}}$ maior que 1 , e rico em combustível quando $\Phi_{\mathrm{e}}$ menor que 1. Quando a mistura é estequiométrica, ocorre à combustão completa de todos os componentes da reação.

Os pós resultantes foram desaglomerados em almofariz de ágata e submetidos à moagem em etanol, por 16 horas, em moinho de bolas com meio de moagem de zircônia, e seco em estufa a $80^{\circ} \mathrm{C}$ por 15 horas, e novamente desagregado em almofariz de ágata. 
Foi também realizado um estudo de calcinação dos pós obtidos a partir da relação estequiométrica entre nitrato e combustível com o objetivo de controlar o tamanho de partículas e área de superfície. Os pós foram submetidos à calcinação em temperaturas entre 700 e $1000^{\circ} \mathrm{C}$ e sub metidos ao mesmo procedimento de moagem citado acima.

Nestes estudos as amostras foram codificadas como CONYSZ mais um valor numérico correspondente à temperatura de calcinação, conforme Tab. 6.

Tabela 6 - Relação de amostras submetidas à calcinação por 1 hora em temperatura entre 700 e $1000 \stackrel{\circ}{ } \mathrm{C}$

\begin{tabular}{cc}
\hline \hline Amostra & $\begin{array}{c}\text { Temperatura } \\
\left({ }^{\circ} \mathrm{C}\right)\end{array}$ \\
\hline \hline CONYZ & Não calcinado \\
\hline CONYZ-700 & 700 \\
\hline \hline CONYZ - 800 & 800 \\
\hline CONYSZ - 900 & 900 \\
\hline CONYSZ - 1000 & 1000 \\
\hline
\end{tabular}

\section{IV.2.1.3 - Mistura de pós}

No método de mistura de pós foram utilizados como material de partida os pós de 8,5YSZ preparados pela rota de coprecipitação, conforme diagrama esquemático de processo apresentado na Fig. 8, e pós de $\mathrm{NiO}$ grau analítico P.A. (Merck, 97\%). Para redução do tamanho de aglomerados dos pós de $\mathrm{NiO}$ foi realizada uma moagem em moinho de alta energia, utilizando meio de moagem de zircônia, em meio álcool etílico por um período de 10 horas. Para avaliar a estabilidade dos pós em suspensão foi adotada a técnica de medida da mobilidade eletroforética e determinação do potencial zeta $(\zeta)$.

No estudo da mobilidade eletroforética (ZetaPALS- Zeta Potential Analyzer, BrookHaven Corp.), utilizou-se suspensões aquosas de NiO e YSZ 
com concentrações de sólidos de 2,61 e 2,40 mg. $\mathrm{mL}^{-1}$ respectivamente, para uma resistência iônica de $10^{-3} \mathrm{M}$ de $\mathrm{KNO}_{3}$ e intervalo de $\mathrm{pH}$ entre 6 e 12. Os ajustes de $\mathrm{pH}$ foram realizados com adições de $\mathrm{HNO}_{3}$ e $\mathrm{KOH}$.

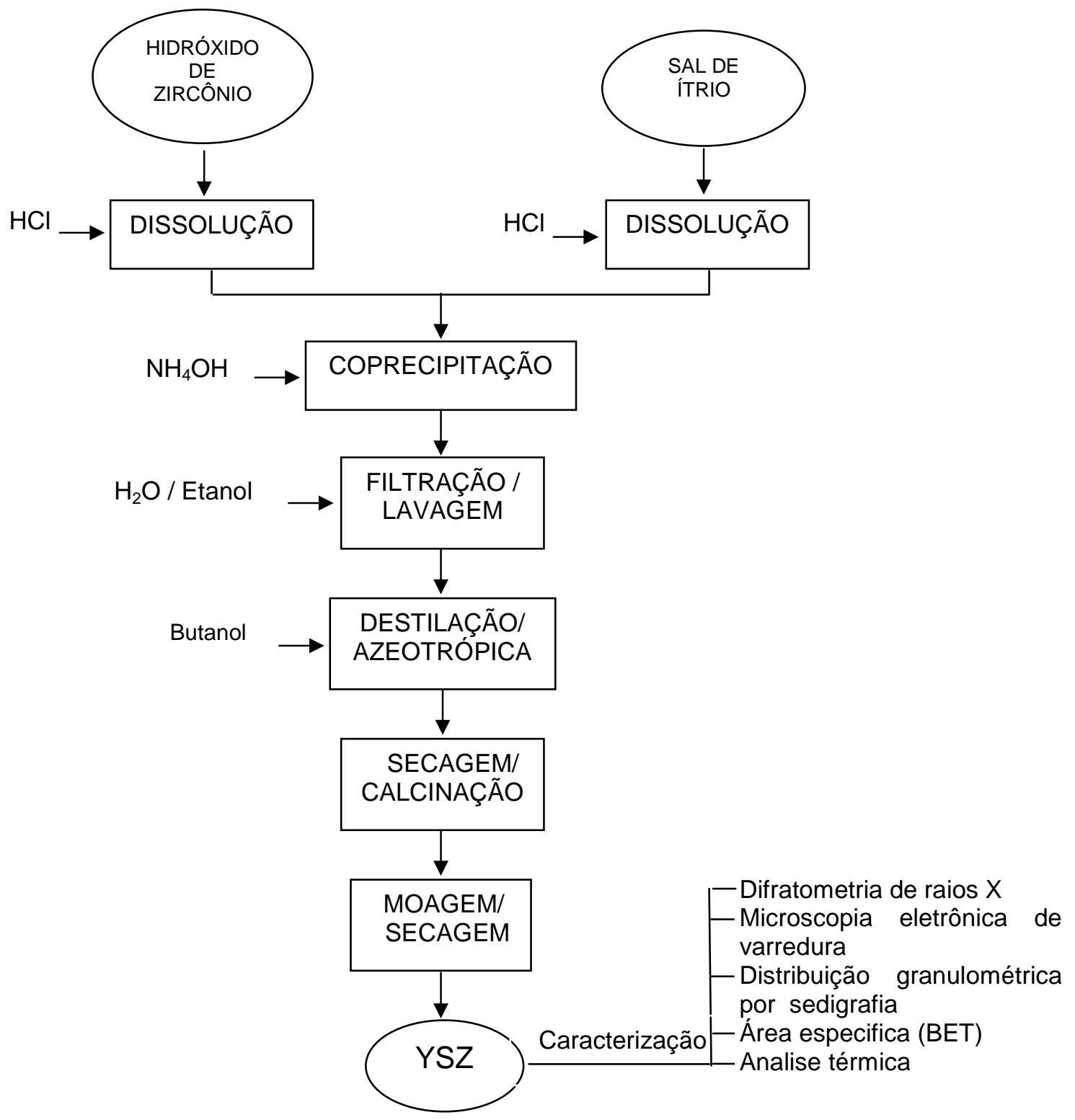

Figura 8 - Diagrama esquemático do processo de síntese por coprecipitação de YSZ

O mesmo estudo foi realizado variando a concentração de dispersante (poliacrilato de amônio) de 0,1, 0,4, 0,8 e 1,6 \%, em relação massa de pó seco. Para ajuste do $\mathrm{pH}$ foram preparadas suspensões com os pós de interesse e retiradas alíquotas de $50 \mathrm{~mL}$. $\mathrm{O}$ ponto de partida foi baseado no valor de $\mathrm{pH}$ apresentado pela suspensão, sendo que os ajustes foram realizados com adições de $\mathrm{HNO}_{3}$ e $\mathrm{KOH}$. 
Para a avaliação da viscosidade foram fixadas as seguintes condições:

(a) concentração de sólido na dispersão = 30\% em massa,

(b) relação mássica $\mathrm{NiO}: 8,5 \mathrm{YSZ}$ de 42:58,

(c) temperatura de medida: ambiente,

(d) concentração de dispersante entre 0,1 e 1,6\% em volume para $\mathrm{NiO}$ e entre 0,4 e $1,6 \%$ para $8,5 Y S Z$.

A homogeneidade da mistura foi avaliada a partir de amostras de pós seco em estufa a $100{ }^{\circ} \mathrm{C}$, submetidos à moagem em moinho de bolas por 15 horas e desagregadas em almofariz de ágata.

\section{IV.3 - Caracterização dos pós}

Os pós de NiO-YSZ obtidos pelas técnicas de coprecipitação, combustão e mistura de pós foram caracterizados química e fisicamente empregando-se as seguintes técnicas:

- Difratometria de raios $\mathrm{X}$ :

As fases cristalinas foram identificadas com o auxílio do difratomêtro Rigaku modelo Multiflex, utilizando radiação $\mathrm{K} \alpha$ do cobre, com passo de varredura de 0,02 graus e tempo de contagem de 1 minuto por passo.

- Microscopia eletrônica de varredura (MEV):

A caracterização da forma e dimensão das partículas/aglomerados foi realizada em microscópio eletrônico de varredura Philips modelo XL 30.

- Análise granulométrica por sedigrafia:

Difração a laser (granulometer 1064, Cilas) para determinação da distribuição de tamanho dos aglomerados

- Adsorção gasosa de $\mathrm{N}_{2}$ a 77K (B.E.T.):

A determinação da área superficial especifica dos pós foi realizada pela técnica de adsorção gasosa de nitrogênio a 77K, utilizando o método B.E.T., com o auxilio do equipamento Quantachrome modelo Nova 1200.

- Termogravimetria

As curvas TG/DTG foram obtidas em termobalança modelo TGA 51 da marca Shimadzu no intervalo de 25 a $900{ }^{\circ} \mathrm{C}$, sob diferentes atmosferas dinâmicas (ar comprimido, nitrogênio e hidrogênio), a taxa de aquecimento foi 
de $10^{\circ} \mathrm{C} \cdot \mathrm{min}^{-1}$. Todos os experimentos foram realizados em cadinho de platina ou alumina.

- Densidade:

A determinação da densidade foi realizada por picnometria de Hélio (Micromeritics, AccuPyc 1330)

- Microscopia eletrônica de transmissão (MET):

Observação da dimensão das partículas, foi realizada com o auxílio de um microscópio JEOL, modelo 200-C

- Composição química

O rendimento da precipitação do $\mathrm{Ni}(\mathrm{OH})_{2}$ foi determinado pela técnica de espectrometria de emissão atômica com fonte de plasma de argônio induzido (ICP-AES - Spectro Flame M 120 E - Spectro Analytical).

A análise química elementar do teor de carbono, hidrogênio e nitrogênio foi realizada nos seguintes equipamentos: Elemental Analyser CHN modelo 2400 e Leco modelo CS-400.

\section{IV.4 - Processamento cerâmico}

Os pós de NiO-YSZ foram conformados, na forma de pastilhas, por prensagem uniaxial em prensa hidráulica manual, aplicando-se uma pressão de $100 \mathrm{MPa}$. Após a compactação as pastilhas foram sinterizadas a uma temperatura otimizada de $1500{ }^{\circ} \mathrm{C}$ ao ar em um forno elétrico de alta temperatura, utilizando-se taxa de aquecimento de $10^{\circ} \mathrm{C} \cdot \mathrm{min}^{-1}$ até $800{ }^{\circ} \mathrm{C}$ e 5 ${ }^{\circ} \mathrm{C} \cdot \mathrm{min}^{-1}$ até a temperatura de sinterização

Para os ensaios de dilatometria, as pastilhas foram prensadas uniaxialmente em matriz de $5,0 \mathrm{~mm}$, aplicando uma pressão de $25 \mathrm{MPa}$ e sinterizadas em um dilatômetro (Setaram Instrumentation - modelo LABSYS S60/51935) até temperatura de $1400{ }^{\circ} \mathrm{C}$ com taxa de aquecimento de $10^{\circ} \mathrm{C} \cdot \mathrm{min}^{-1}$, em ar atmosférico. 


\section{IV.5 - Estudo de sinterização}

Os pós de NiO-YSZ foram conformados por prensagem uniaxial em prensa hidráulica manual, aplicando-se uma pressão de $25 \mathrm{MPa}$, na forma de pastilhas com diâmetro de 5,0 $\mathrm{mm}$ e altura de $6,0 \mathrm{~mm}$. Todas as amostras foram preparadas com valores de densidade e dimensões com a menor variação possível de maneira que estes parâmetros não influenciassem na análise da retração linear final. Para avaliação da evolução da densificação, porosidade e microestrutura as amostras foram sinterizadas em forno tipo caixa, sob atmosfera dinâmica de ar, adotando-se a taxa de aquecimento de $10 \stackrel{\circ}{\circ} \mathrm{C} \cdot \mathrm{min}^{-1} \mathrm{sem}$ isoterma. $\mathrm{O}$ intervalo de temperatura foi fixado entre $1000 \mathrm{e}$ $1500^{\circ} \mathrm{C}$.

O estudo de retração linear e taxa de densificação foram realizadas em dilatômetro (Setaram Labsys TMA), sob atmosfera dinâmica de ar sintético, adotando-se diferentes taxas de aquecimento $\left(5,10,15\right.$ e $\left.20 \stackrel{\circ}{\circ} \mathrm{C} \cdot \mathrm{min}^{-1}\right)$ e a temperatura máxima do ensaio fixado em $1400^{\circ} \mathrm{C}$ devido à limitação do equipamento.

No estudo do método quase-isotérmico por passo em dilatômetro, (Setaram Labsys TMA) as isotermas foram programadas para duração de 30 minutos a cada $50^{\circ} \mathrm{C}$ durante $o$ aquecimento sob atmosfera dinâmica de ar sintético e taxa de aquecimento de $10 \stackrel{\circ}{\circ} \mathrm{C} \cdot \mathrm{min}^{-1}$. A faixa de temperatura avaliada foi entre 900 e $1400^{\circ} \mathrm{C}$.

\section{IV.5 - Estudo da cinética de redução}

\section{IV.5.1- Cinética de redução dos pós}

Neste estudo, os pós obtidos pelos três métodos de síntese foram submetidos a um tratamento térmico a $1350^{\circ} \mathrm{C}$ por 1 hora. Os ensaios para determinação da energia de ativação foram realizados em termobalança, em atmosfera dinâmica de $20 \% \mathrm{H}_{2}$ em balanço com $\mathrm{Ar}$ com vazão fixada em $100 \mathrm{~mL} \cdot \mathrm{min}^{-1}$ desde o início do aquecimento e uma taxa de aquecimento entre 5 e $20 \stackrel{\circ}{\circ} \cdot \mathrm{min}^{-1}$. 
A energia de ativação para redução do $\mathrm{NiO}$ a partir de dados da TG/DTG obtidas em termobalança modelo TGA 51 da marca Shimadzu com taxa constante de aquecimento foi calculada usando a equação [112].

$$
\ln \left(\frac{\alpha}{T_{m}^{2}}\right)=\frac{E_{a}}{R T_{m}}+\ln \left(\frac{R k_{0}}{E_{a}}\right)
$$

onde: $\alpha$ é a taxa de aquecimento (K.min $\left.{ }^{-1}\right), T_{m}$ é a temperatura para a máxima taxa de redução $(K), E_{a}$ é a energia de ativação $\left(\mathrm{J} \mathrm{mol}^{-1}\right), \mathrm{R}$ é a constante universal dos gases $\left(8,314 \mathrm{~J}_{\mathrm{mol}}{ }^{-1} \cdot \mathrm{K}^{-1}\right)$ e $\mathrm{k}_{0}$ é o fator pré-exponencial na equação de Arrhenius $\left(\mathrm{min}^{-1}\right)$.

\section{IV.5.2- Cinética de redução do corpo cerâmico}

\section{IV.5.2.1- Corpo cerâmico sem formador de poros}

Para estudar a cinética de redução foram preparadas várias amostras do compósitos sinterizados nas quais foram observadas as mudanças de massa que ocorrem durante o processo de redução do $\mathrm{NiO}$ para $\mathrm{Ni}^{0}$, em função do tempo.

As amostras obtidas pelos três métodos foram aquecidas a $900{ }^{\circ} \mathrm{C}$ em um forno do tipo caixa a uma taxa de aquecimento de $10^{\circ} \mathrm{C} \cdot \mathrm{min}^{-1}$, em atmosfera inerte de argônio e mantida a $900{ }^{\circ} \mathrm{C}$. $\mathrm{Na}$ isoterma as amostras foram submetidas a uma atmosfera redutora com $4 \% \mathrm{H}_{2}$ em balanço com $96 \%$ de $\mathrm{Ar}$, por período entre 5 minutos e 2 horas, e resfriadas a temperatura ambiente em atmosfera dinâmica de Ar. A vazão de gases foi mantida em 100 $\mathrm{mL}$. $\mathrm{min}^{-1}$ (gás argônio e gás $4 \% \mathrm{H}_{2}$ em balanço com $96 \%$ de Ar). A porosidade da amostra depois da redução foi determinada por imersão em água, conforme ASTM standard C20-00, em função da fração de NiO reduzido.

Para mostrar a evolução do processo de redução na superfície dos óxidos obtidos pelo método de mistura de pós em função do tempo, as amostras foram polidas e as micrografias das secções transversais obtidas por microscopia ótica. 


\section{IV.5.2.2 - Corpo cerâmico com formador de poro}

\section{IV.5.2.2.1 - Amido de milho}

Os estudos da cinética de redução do $\mathrm{NiO}$ para $\mathrm{Ni}^{0}$ foram realizados em amostras obtidas por coprecipitação e as curvas TG/DTG foram obtidas em termobalança modelo TGA 51 da marca Shimadzu no intervalo de 25 a $900{ }^{\circ} \mathrm{C}$, sob diferentes atmosferas dinâmicas (ar comprimido, nitrogênio e hidrogênio). No caso da utilização de $50 \%$ de hidrogênio em balanço com nitrogênio a vazão foi fixada em $100 \mathrm{~mL} \cdot \mathrm{min}^{-1} \mathrm{com}$ taxa de aquecimento de $20{ }^{\circ} \mathrm{C} \cdot \mathrm{min}^{-1}$. Todos os experimentos foram realizados em cadinho de platina.

Para o estudo da influência da porosidade na cinética de redução do óxido de níquel foram preparadas amostras de NiO-YSZ com amido de milho, que tem a função de formar poros na cerâmica. A porcentagem em massa do formador de poros foi de 10, 15 e $20 \%$ em relação à massa de $\mathrm{NiO}$ presente no compósito. A mistura dos pós foi feita em meio álcool etílico, submetido à moagem por 15 horas e seco em estufa a $80^{\circ} \mathrm{C}$ e em se guida desaglomerado em almofariz de ágata. As condições de conformação das pastilhas obedeceram ao mesmo critério das amostras sem formador de poros. No processo de sinterização foi mantida uma isoterma de $600^{\circ} \mathrm{C}$ por meia hora para garantir que todo amido tenha sido decomposto e eliminado da amostra e finalmente mantido em uma isoterma de $1350^{\circ} \mathrm{C}$ por 1 hora. Todas as etapas de sinterização foram realizadas em ar atmosférico.

\section{IV.5.2.2.2 - Farinha de jatobá e negro de fumo}

Para o estudo da cinética de redução do $\mathrm{NiO}$ com farinha de jatobá foram preparadas amostras com 20,30, 40 e $50 \%$ de formador de poros em relação à massa de $\mathrm{NiO}$ presente no compósito. Com formador de poros negro de fumo foi adotado a concentração de $30 \%$ em massa. A preparação da amostra com os pós obtidos pelos três métodos obedeceu ao mesmo critério adotado no experimento com amido de milho. As amostras foram sinterizadas a $1350^{\circ} \mathrm{C}$ por 1 hora. Como a porosidade para as amostr as com 40 e $50 \%$ de formador de poros ficaram muito acima do recomendado os estudos da cinética 
de redução foi realizado apenas nas amostras com 20 e 30\% de formador de poros.

$\mathrm{Na}$ isoterma as amostras foram submetidas a uma atmosfera redutora com $4 \% \mathrm{H}_{2}$ em balanço com $96 \%$ de Ar, por período entre 5 minutos e 4 horas, e resfriadas a temperatura ambiente em atmosfera dinâmica de Ar.

A porosidade da amostra depois da redução foi determinada por imersão em água, conforme ASTM standard C20-00.

\section{IV.6 - Caracterização dos produtos sinterizados e submetidos à redução com hidrogênio}

As principais técnicas de caracterização utilizadas na caracterização das cerâmicas são mencionadas a seguir:

- Análise por difratometria de raios $X$

Esta análise tem como finalidade a identificação das fases cristalinas que constituem o compósito

- Medida de densidade hidrostática

A densidade hidrostática das amostras sinterizadas foi determinada pelo método do principio de Archimedes, utilizando a equação:

$$
\rho_{\text {amostra }}=\frac{m_{s} \cdot \rho_{\text {água }}}{m_{u}-m_{i}}
$$

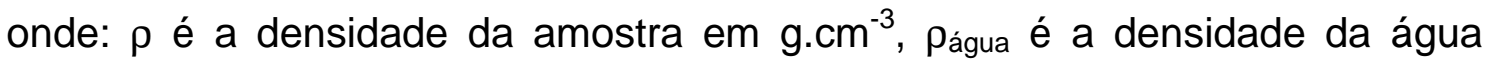
$\left(\mathrm{g} . \mathrm{cm}^{-3}\right)$ na temperatura do ensaio e $\mathrm{m}_{\mathrm{s}}, \mathrm{m}_{\mathrm{u}}$ e $\mathrm{m}_{\mathrm{i}}$ são a massa seca, úmida $\mathrm{e}$ imersa respectivamente.

- Determinação da porosidade

A porosidade aparente é determinada pela relação entre o volume total dos poros abertos e o volume externo da amostra e é expressa em porcentagem, segundo a equação:

$$
P(\%)=\frac{m_{u}-m_{s}}{m_{u}-m_{i}}
$$


Sendo que o volume dos poros abertos é obtido subtraindo-se a massa seca $\left(m_{s}\right)$ da massa úmida $\left(m_{u}\right)$ e o volume externo da amostra é obtido subtraindo-se a massa imersa $\left(m_{i}\right)$ da massa úmida $\left(m_{\mathrm{u}}\right)$.

- Determinação da densidade teórica

A densidade téorica é calculada segundo a regra da mistura:

$$
\rho_{\mathrm{s}}=\rho_{\mathrm{NiO}} \cdot \mathrm{V}_{\mathrm{NiO}}+\rho_{\mathrm{YSZ}} \cdot V_{\mathrm{YSZ}}
$$

onde: $\rho_{\mathrm{s}}$ é a densidade da amostra, $\rho_{\mathrm{NiO}}$ é a densidade teórica do óxido de níquel, $\rho_{Y S Z}$ é a densidade teórica do YSZ, $\mathrm{V}_{\mathrm{NiO}}$ e $\mathrm{V}_{\mathrm{YSZ}}$ são o volume fracional de NiO e YSZ, respectivamente.

- Dilatometria

Esta técnica foi utilizada para o estudo da sinterização.

- Termogravimetria

As curvas TG/DTG foram obtidas em termobalança, modelo TGA 51 da marca Shimadzu, no intervalo de 25 a $900{ }^{\circ} \mathrm{C}$, sob diferentes atmosferas dinâmicas (ar comprimido, nitrogênio e hidrogênio). As taxas de aquecimentos foram de 5, 10,15 e $20{ }^{\circ} \mathrm{C} \cdot \mathrm{min}^{-1}$. Todos os experimentos foram realizados em cadinho de platina ou alumina.

- Análise microestrutural

A técnica de microscopia eletrônica de varredura (MEV) foi adotada para observação das superfícies de fratura das amostras, mais especificamente do tamanho e formato dos grãos e poros. As observações dos contornos de grãos foram realizadas em amostras com a superfície polida e submetida a ataque térmico em amostras não reduzida. Com o auxílio da técnica de espectrometria por dispersão de energia (EDS) foi realizadas análises químicas qualitativas nos grão.

- Microscopia ótica (Olympus - PMEU 3)

Esta análise foi realizada com o intuito de avaliar a evolução do processo de redução na superfície dos óxidos em função do tempo, em atmosfera redutora. 


\section{V - RESULTADOS E DISCUSSÃO}

\section{V.1 - Rota de coprecipitação}

$\mathrm{Na}$ rota de coprecipitação de zircônia estabilizada com ítria o procedimento normalmente adotado consiste na adição de excesso de agente precipitante para assegurar o máximo rendimento na precipitação dos cátions na forma de hidróxido, uma vez que a precipitação, em meio de cloretos dos cátions zircônio e ítrio, na forma de hidróxido, ocorre em pH entre 1,9 e 4,2 para o zircônio e pH 6,8 para o ítrio [41]. Contudo, quando o cátion níquel é adicionado para síntese do compósito NiO-YSZ, este excesso de agente precipitante, neste caso $\circ \mathrm{NH}_{4} \mathrm{OH}$, geralmente contribui para um menor rendimento na precipitação do $\mathrm{Ni}(\mathrm{OH})_{2}$ devido a formação de complexo solúvel de níquel na forma de $\left[\mathrm{Ni}\left(\mathrm{NH}_{3}\right)_{n}\right]^{2+}$ onde $1 \leq \mathrm{n} \leq 6$. Assim sendo, para definição das melhores condições de precipitação dos hidróxidos mistos, torna-se necessário um estudo individualizado da precipitação do níquel.

A Fig. 9.a relaciona a concentração de $\mathrm{NH}_{4} \mathrm{OH}$ com o pH do meio. $\mathrm{Na}$ Fig. 9.b observa-se a concentração mínima de níquel no sobrenadante, ou seja, o máximo rendimento de precipitação, foi obtido em $\mathrm{pH}$ final de 8,8 a 98 ¿ $\mathrm{C}$ e a temperatura ambiente.

$\mathrm{Na}$ obtenção do $\mathrm{Ni}(\mathrm{OH})_{2}$, o rendimento da precipitação depende das concentrações dos íons hidroxilas e amônio, segundo o equilíbrio do agente precipitante:

$$
\mathrm{NH}_{4}{ }^{+} \text {(aq) }+\mathrm{OH}_{(\text {aq) }}^{-} \rightleftarrows \mathrm{NH}_{3(\mathrm{aq})}+\mathrm{H}_{2} \mathrm{O}_{(\mathrm{l})}
$$

Em solução aquosa de $\mathrm{NiCl}_{2} \cdot 6 \mathrm{H}_{2} \mathrm{O}$, a adição de $\mathrm{NH}_{4} \mathrm{OH}$ inicialmente atua como uma base fraca, fornecendo o íon hidroxila, para precipitar o níquel na forma de $\mathrm{Ni}(\mathrm{OH})_{2}$. Quando a precipitação atinge seu valor máximo, um aumento na concentração de $\mathrm{NH}_{3}$ livre aumenta a complexação de $\mathrm{Ni}^{2+}$. 

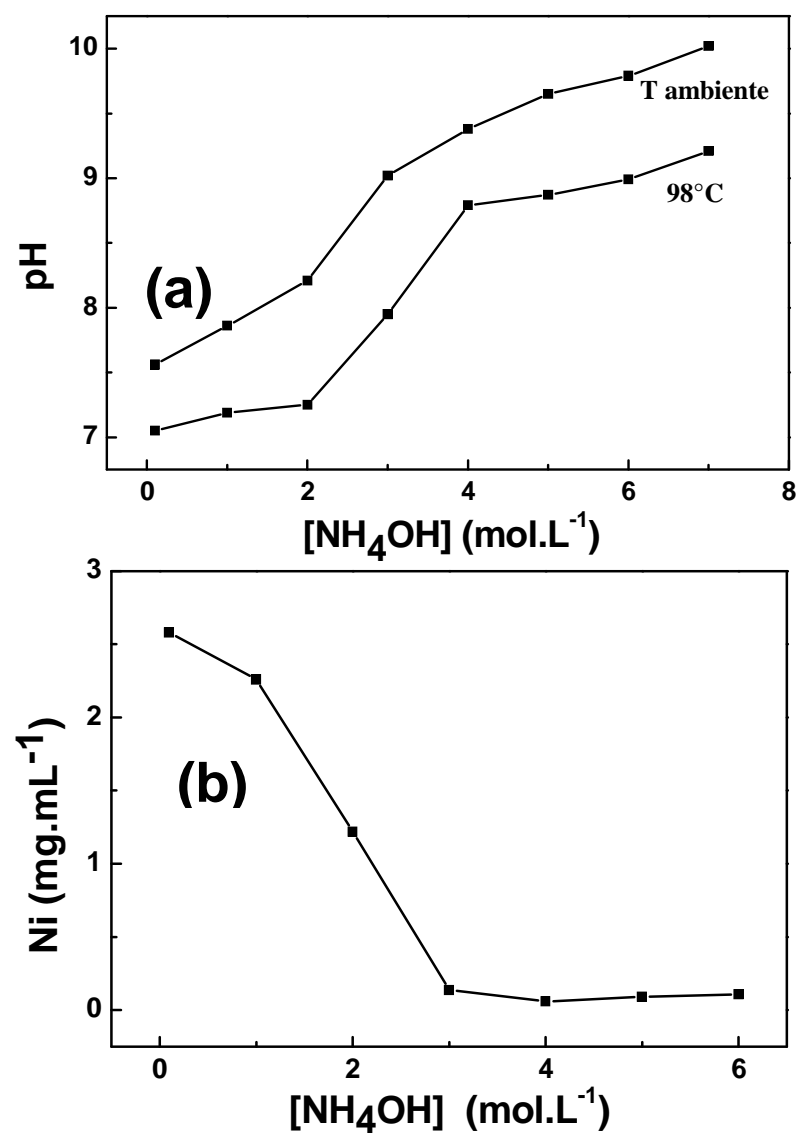

Figura 9 - Evolução do pH (a) e concentração de níquel (b) na solução mãe, em função da concentração molar de hidróxido de amônio.

Como pode ser observado na curva apresentada na Fig. 10.a, para baixos valores de $\mathrm{pH}$ o rendimento da precipitação é baixo pois a concentração de íon $\mathrm{OH}^{-}$é insuficiente para atingir o valor do produto de solubilidade do $\mathrm{Ni}(\mathrm{OH})_{2}$. Para valores de $\mathrm{pH} 8,8$ o rendimento de precipitação do $\mathrm{Ni}(\mathrm{OH})_{2}$ atinge o seu valor máximo. $\mathrm{Em} \mathrm{pH}$ superior a $\mathrm{pH} 8,9$, o aumento na concentração de $\mathrm{NH}_{3}$ conduz à formação de complexos entre o $\mathrm{Ni}^{2+}$ e a $\mathrm{NH}_{3}$. Como as moléculas de água são fracamente ligadas ao $\mathrm{Ni}^{2+}$, as moléculas de $\mathrm{NH}_{3}$ começam a competir e sucessivamente vão substituindo as moléculas de $\mathrm{H}_{2} \mathrm{O}$ formando complexos solúveis de níquel conforme a equação:

$$
\left[\mathrm{Ni}\left(\mathrm{H}_{2} \mathrm{O}\right)_{6}\right]^{2+}{ }_{(\mathrm{aq})}+6 \mathrm{NH}_{3(\mathrm{aq})} \longrightarrow\left[\mathrm{Ni}\left(\mathrm{NH}_{3}\right)_{6}\right]^{2+}{ }_{(\mathrm{aq})}+6 \mathrm{H}_{2} \mathrm{O}_{(\mathrm{l})}
$$


Na Fig. 10.b é apresentado o rendimento da precipitação do cátion níquel em função da sua concentração $(0,01-0,2 \mathrm{M})$ para um $\mathrm{pH}$ ajustado em 9,5 . Observa-se que há um decréscimo de aproximadamente $3 \%$ na precipitação com 0 aumento da concentração de níquel entre 0,01 e 0,1 mol. $\mathrm{L}^{-1}$, decréscimo este acentuado para $20 \%$, quando a concentração é aumentada para 0,2 mol. $\mathrm{L}^{-1}$.
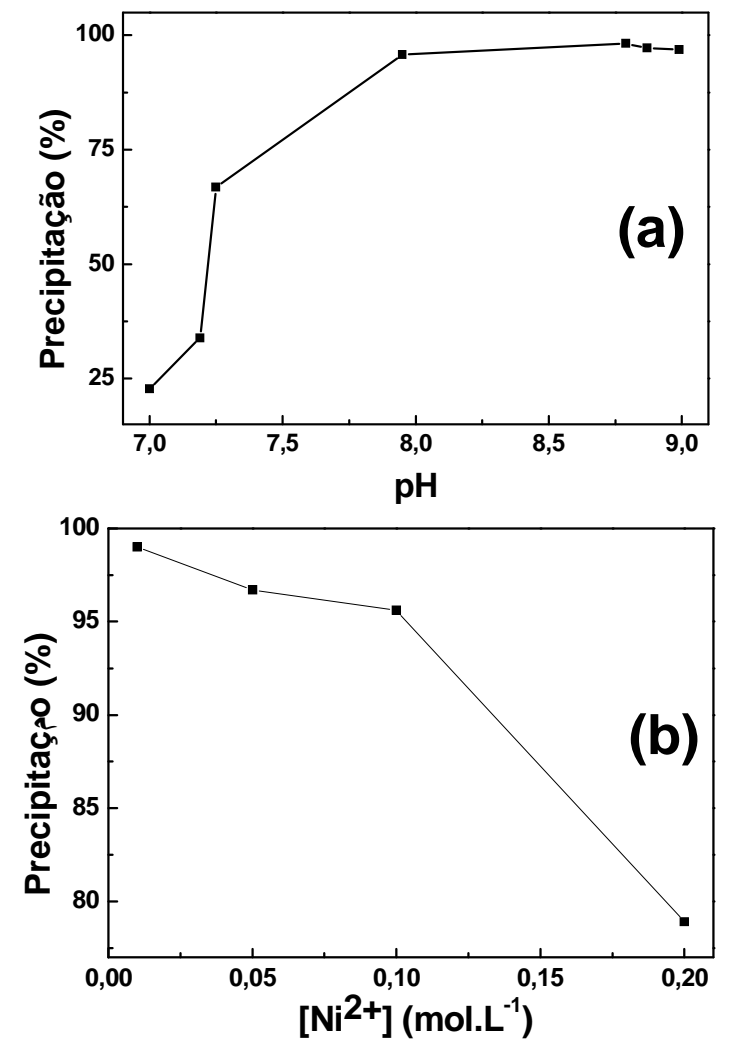

Figura 10 - Rendimento da precipitação de $\mathrm{Ni}$ em função do pH (a), e concentração deste cátion na solução precursora cujo pH foi fixado em 9,5 (b)

As formações do complexo solúveis de níquel podem ser comprovadas pela mudança da cor da solução, que é uma propriedade característica dos elementos de transição. Em soluções aquosas de níquel, em presença de excesso de $\mathrm{NH}_{4} \mathrm{OH}$, ocorre a seguinte transformação: em água, o níquel (II) apresenta-se como um complexo $\left[\mathrm{Ni}_{(}\left(\mathrm{H}_{2} \mathrm{O}\right)_{6}\right]^{2+}$ de cor verde, ao se adicionar $\mathrm{NH}_{3}$ as estruturas de vários complexos de $\mathrm{Ni}^{2+} / \mathrm{H}_{2} \mathrm{O} / \mathrm{NH}_{3}$ são formadas e co-existem em solução aquosa. As proporções relativas das espécies dependem da quantidade $\mathrm{NH}_{3}$ adicionada à solução aquosa de $\mathrm{Ni}^{2+}$. Quando $\mathrm{NH}_{3}$ concentrado é adicionado em excesso, o íon complexo $\left[\mathrm{Ni}\left(\mathrm{NH}_{3}\right)_{6}\right]^{2+}$ de cor 
azul é formado. Isto ocorre, pois a absorção de luz é um processo subtrativo de cor e sendo vermelho e laranja cores complementares da cor verde e azul, respectivamente. Na Fig. 11 é apresentada a variação na cor da solução de níquel, em função da concentração de $\mathrm{NH}_{3}$ presente na solução.

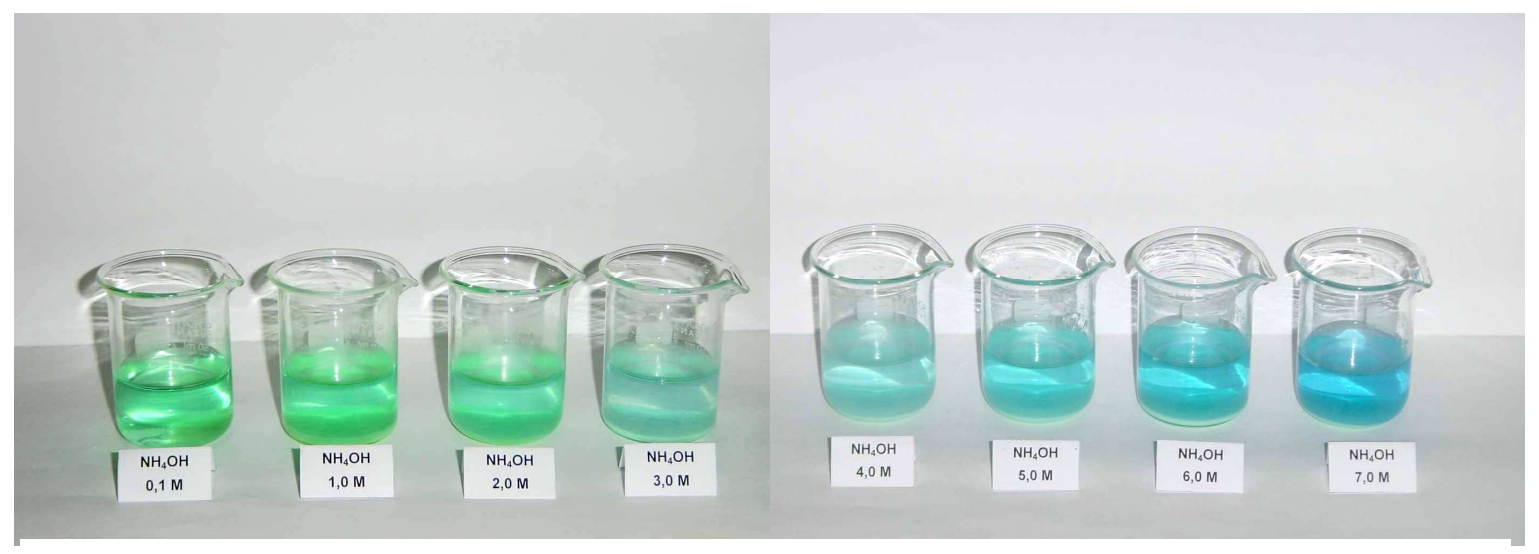

Figura 11 - Variação na coloração das soluções contendo níquel em função da concentração de $\mathrm{NH}_{4} \mathrm{OH}$

O difratograma de raios $\mathrm{X}$ para a amostra isolada em $\mathrm{pH} 8,8$, ilustrado na Fig. 12, indicou a formação de $\beta-\mathrm{Ni}(\mathrm{OH})_{2}$, que cristaliza no sistema hexagonal com a estrutura do tipo "brucita".

Para avaliar o rendimento da precipitação do cátion níquel, em presença dos cátions $\mathrm{Zr}^{4+}$ e $\mathrm{Y}^{3+}$, adotou-se as condições otimizadas no estudo individualizado da precipitação do hidróxido de níquel, ou seja: $\left[\mathrm{Ni}^{2+}\right]=0,1 \mathrm{~mol} \cdot \mathrm{L}^{-1} ; \quad \mathrm{T}=98^{\circ} \mathrm{C} ; \mathrm{pH}=9,5$ e $\left(\mathrm{Y}_{2} \mathrm{O}_{3}\right)=8 \mathrm{~mol} \%$ em relação a zircônia utilizadas. Em todas as composições estudadas houve um decréscimo no rendimento da precipitação do níquel com a diminuição da concentração de $\mathrm{NiO}$ no compósito, conforme apresentado na Tab. 7. 


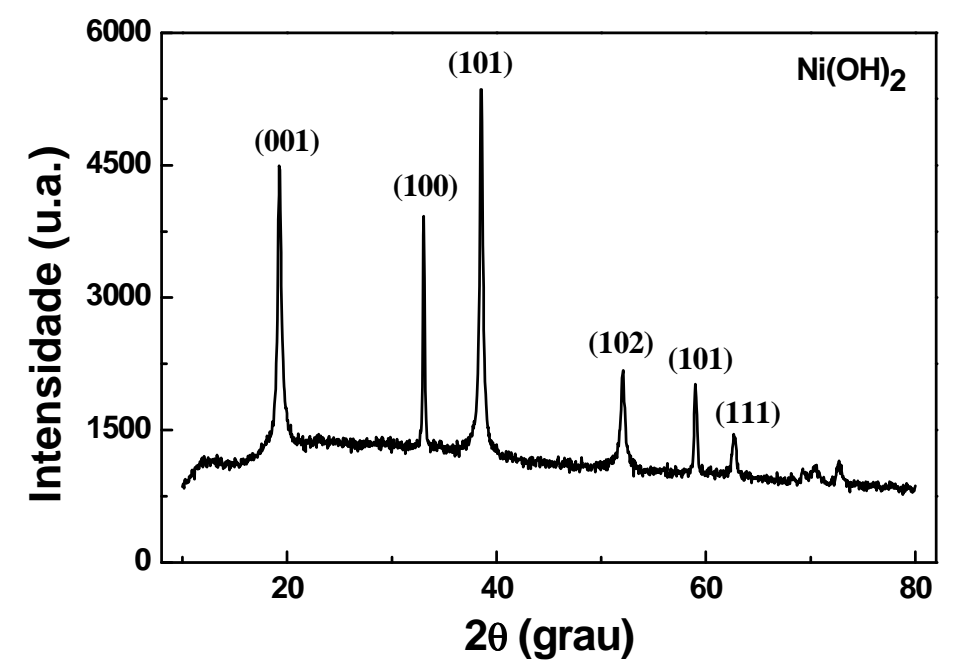

Figura 12 - Difratograma de raios $\mathrm{X}$ da amostra $\beta$ - Ni(OH)$)_{2}$

Tabela 7 - Rendimento da precipitação de níquel no compósito NiO-YSZ e composição química das amostras.

\begin{tabular}{ccc}
\hline $\begin{array}{c}\text { Solução precursora } \\
\text { Composição nominal em } \\
\text { massa } \\
(\%)\end{array}$ & $\begin{array}{c}\text { Rendimento da } \\
\text { precipitação } \mathrm{Ni}^{2+}\end{array}$ & $\begin{array}{c}\text { Precipitado } \\
\text { Composição Real em } \\
\text { massa } \\
(\%)\end{array}$ \\
\hline \hline $29 \% \mathrm{NiO}: \mathrm{YSZ}$ & 90,2 & $26,1 \% \mathrm{NiO}: \mathrm{YSZ}$ \\
$57 \% \mathrm{NiO}: \mathrm{YSZ}$ & 90,2 & $51,4 \% \mathrm{NiO}: \mathrm{YSZ}$ \\
$79 \% \mathrm{NiO}: \mathrm{YSZ}$ & 97,8 & $77,3 \% \mathrm{NiO}: \mathrm{YSZ}$ \\
$100 \% \mathrm{NiO}$ & 98,2 & $\mathrm{NiO}$ \\
\hline \hline
\end{tabular}

Em um estudo de precipitação do compósito NiO-YSZ Grgicak et al. [57] introduziu gás amônia na solução até $\mathrm{pH}=11,0$ e obteve um rendimento de precipitação do $\mathrm{NiO}$ de $12 \%$, valor muito abaixo do $50 \%$ em massa calculado. Marinsek et al. [87] também utilizou o gás amônia como agente precipitante e introduziu o gás em uma solução aquecida a $97^{\circ} \mathrm{C}$ até $\mathrm{pH}=8,0$. Neste estudo 
para uma composição teórica de $81,09 \%$ em massa de $\mathrm{Ni}$, foi obtida uma composição de $62,5 \%$ em massa de Ni no compósito, que corresponde a um rendimento de precipitação do níquel de aproximadamente $77 \%$. Estes resultados comprovam a importância do controle do $\mathrm{pH}$ e temperatura para evitar a formação de complexos e maximizar a precipitação do $\mathrm{Ni}(\mathrm{OH})_{2}$.

$\mathrm{Li}$ et al. analisaram $\mathrm{O}$ efeito de diferentes agentes precipitantes no rendimento de precipitação de $\mathrm{Ni}(\mathrm{OH})_{2}$ no compósito NiO-YSZ, para um $\mathrm{pH}$ final de aproximadamente 8,5. Para $\circ \mathrm{NH}_{3} \cdot \mathrm{H}_{2} \mathrm{O} \circ$ rendimento de precipitação de níquel foi de 20,9\% para uma composição teórica de $45 \%$ em volume de $\mathrm{Ni}$ [59]. Por sua vez, para uma solução tampão de $\mathrm{NH}_{3} \cdot \mathrm{H}_{2} \mathrm{O}-\mathrm{NH}_{4} \cdot \mathrm{HCO}_{3} \mathrm{O}$ rendimento de precipitação foi de $94,01 \%$. Uma das causas para esse baixo rendimento na precipitação com $\mathrm{NH}_{4} \mathrm{OH}$ provavelmente esteja relacionada com a elevada concentração molar de Ni na solução precursora, 1,0 mol..-1.

Na Fig. 13 apresenta-se as curvas TG/DTG dos pós obtidos na forma de hidróxido seco. O primeiro evento de perda de massa corresponde à eliminação de moléculas de água que ocorre lenta e gradativamente entre $25 \mathrm{e}$ $280^{\circ} \mathrm{C}$. O segundo evento ocorre na faixa entre 280 e $380^{\circ} \mathrm{C}$ ( $T_{\text {pico }} \mathrm{DTG}-$ 320 C) está relacionado à eliminação do solvente o rgânico, proveniente da destilação azeotrópica e também da eliminação dos grupos hidroxilas ligados aos cátions. A $700{ }^{\circ} \mathrm{C}$ todos os cátions metálicos en contram-se na forma de óxido.

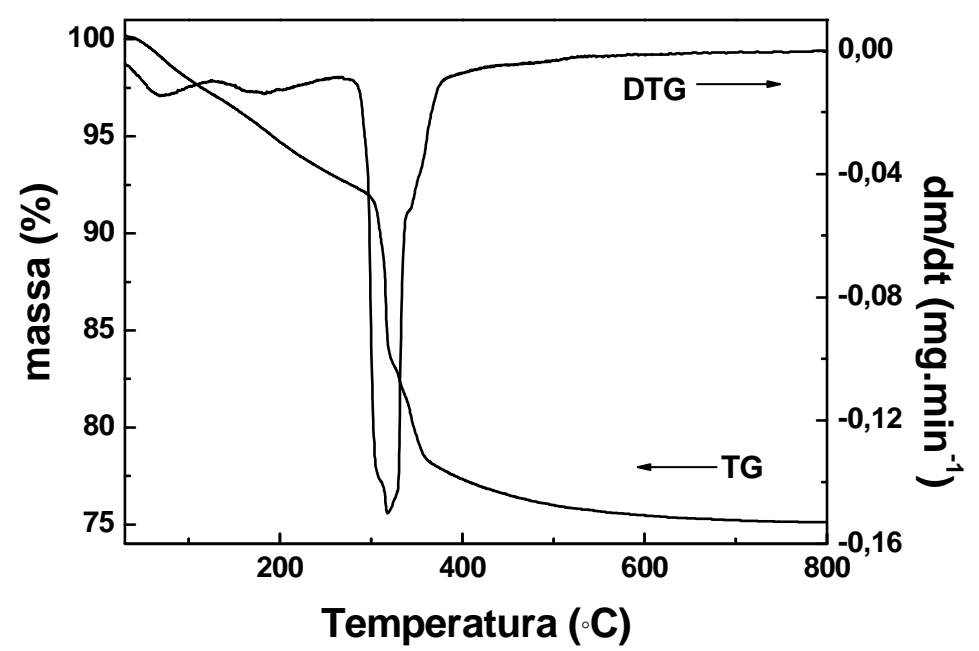

Figura 13 - Curvas TG/DTG dos pós de hidróxido seco otidos pela rota da coprecipitação, com taxa de aquecimento de $10{ }^{\mathrm{C}} \mathrm{C} \cdot \mathrm{m} \mathrm{in}^{-1}$ e sob atmosfera dinâmica de ar comprimido. 
Na Tab. 8 e Fig. 14 são apresentadas as características físicas do pó $52 \% \mathrm{NiO}$ : YSZ, obtido por coprecipitação, calcinado a $800{ }^{\circ} \mathrm{C}$ e moído em moinho de bolas por um período de 15 horas.

Tabela 8 - Características físicas dos pós obtidos por coprecipitação, calcinados a $800{ }^{\circ} \mathrm{C}$, por um período de uma hora e submetidos a moagem em moinho de bolas.

\begin{tabular}{cccc}
\hline $\begin{array}{c}\text { Tamanho médio } \\
\text { do aglomerado } \\
(\mu \mathrm{m})\end{array}$ & $\begin{array}{c}\text { Área de superfície } \\
\text { específica } \\
\left(\mathrm{m}^{2} \mathrm{~g}^{-1}\right)\end{array}$ & $\begin{array}{c}\text { Densidade } \\
\left(\mathrm{g} \cdot \mathrm{cm}^{-3}\right)\end{array}$ & $\begin{array}{c}\text { Tamanho } \\
\text { médio de } \\
\text { partícula } \\
(\mathrm{nm})\end{array}$ \\
\hline \hline 0,3 & 23,2 & 6,00 & 20 \\
\hline \hline
\end{tabular}

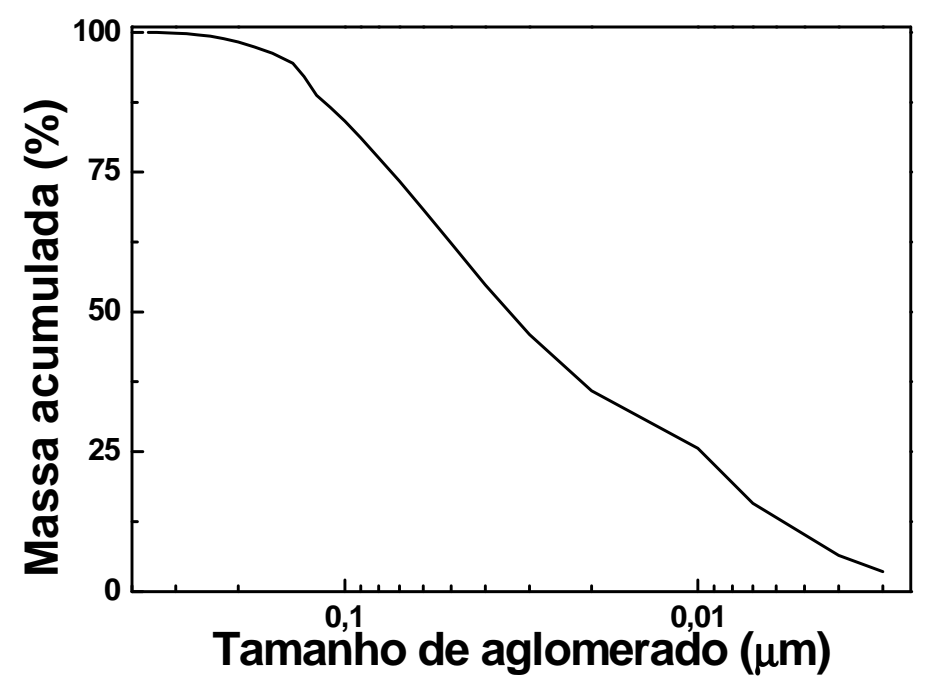

Figura 14 - Distribuição granulométrica dos pós NiO-YSZ obtidos após calcinação a $800^{\circ} \mathrm{C}$ e moagem

O padrão de difração de raios $X$ (Fig. 15) da amostra de pó obtida pela rota de coprecipitação indica a formação de uma mistura de óxido de níquel com estrutura ortorrômbica e zircônia estabilizada com ítria com estrutura tetragonal e/ou cúbica 


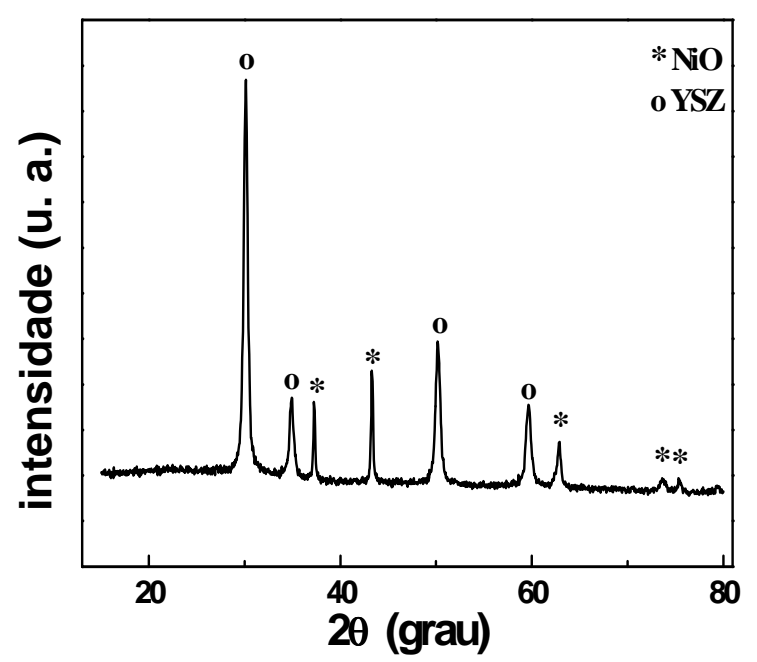

Figura 15- Padrão de difração de raios $X$ dos pós NiO 52\% em massa YSZ obtidos por coprecipitação, calcinação a $800^{\circ} \mathrm{C}$ por uma hora e moagem em moinho de bolas.

Como pode ser observado na micrografia obtida por microscopia eletrônica de varredura, Fig. 16.a, as partículas encontram-se na forma de aglomerados com tamanho submicrométrico. Por sua vez, na imagem obtida por microscopia eletrônica de transmissão, Fig. 16.b, observa-se que as partículas apresentam formato arredondado e com dimensões de aproximadamente $20 \mathrm{~nm}$.

A curva da retração linear ilustrada na Figura 17 mostra que o compósito apresenta uma leve expansão térmica antes da mudança da dimensão. A retração inicia a partir de $1110{ }^{\circ} \mathrm{C}$ e a temperatura na máxima taxa de retração ocorre em $1366^{\circ} \mathrm{C}$. A retração total do compósito foi de $23,5 \%$. 


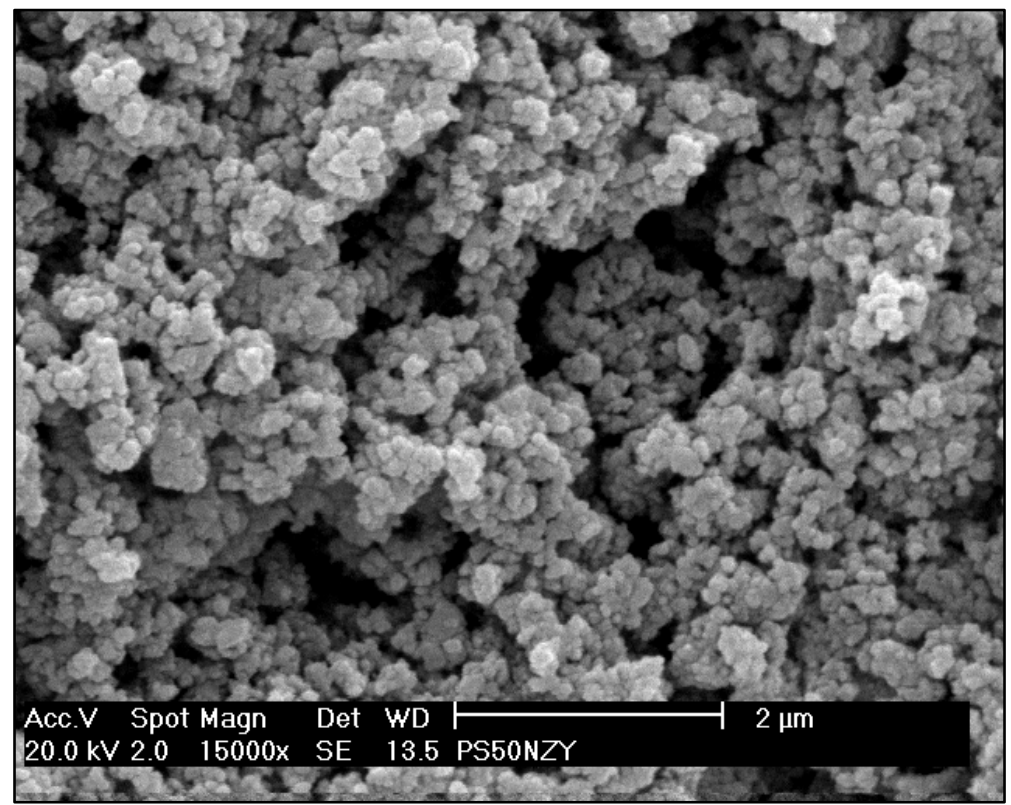

(a)

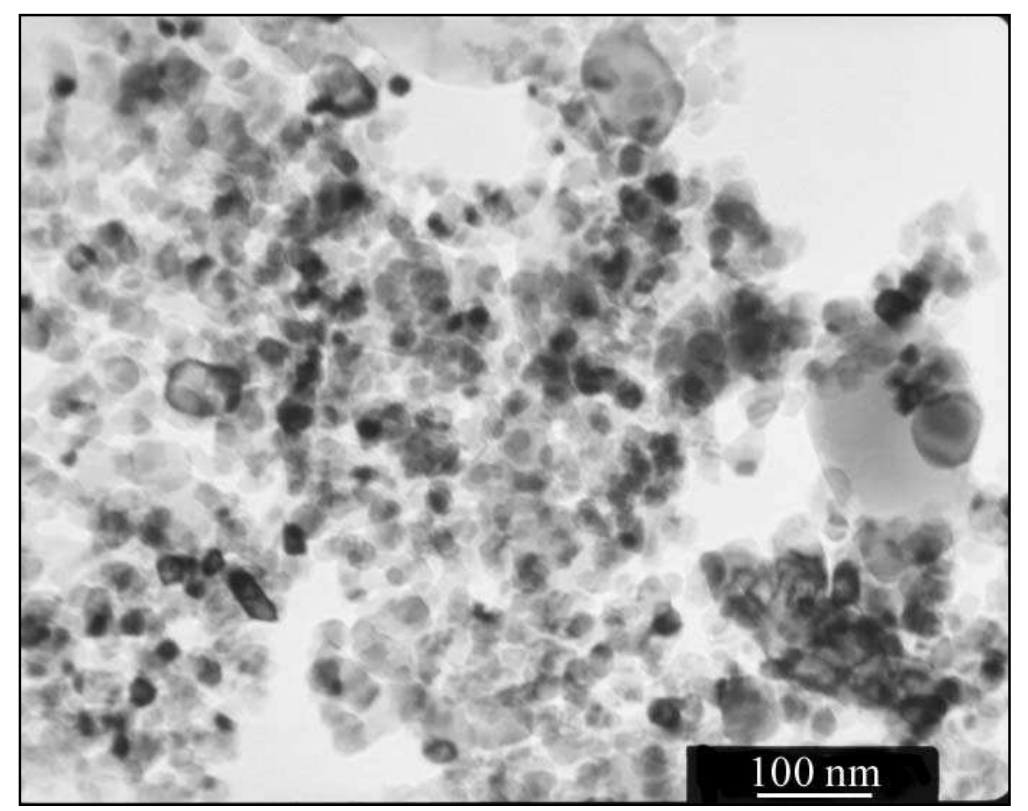

(b)

Figura 16 - Micrografias obtidas por MEV (a) e MET (b) dos pós de $52 \%$ em massa NiO-YSZ obtidos por coprecipitação, calcinação a $800{ }^{\circ} \mathrm{C}$ por uma hora e moagem em moinho de bolas. 

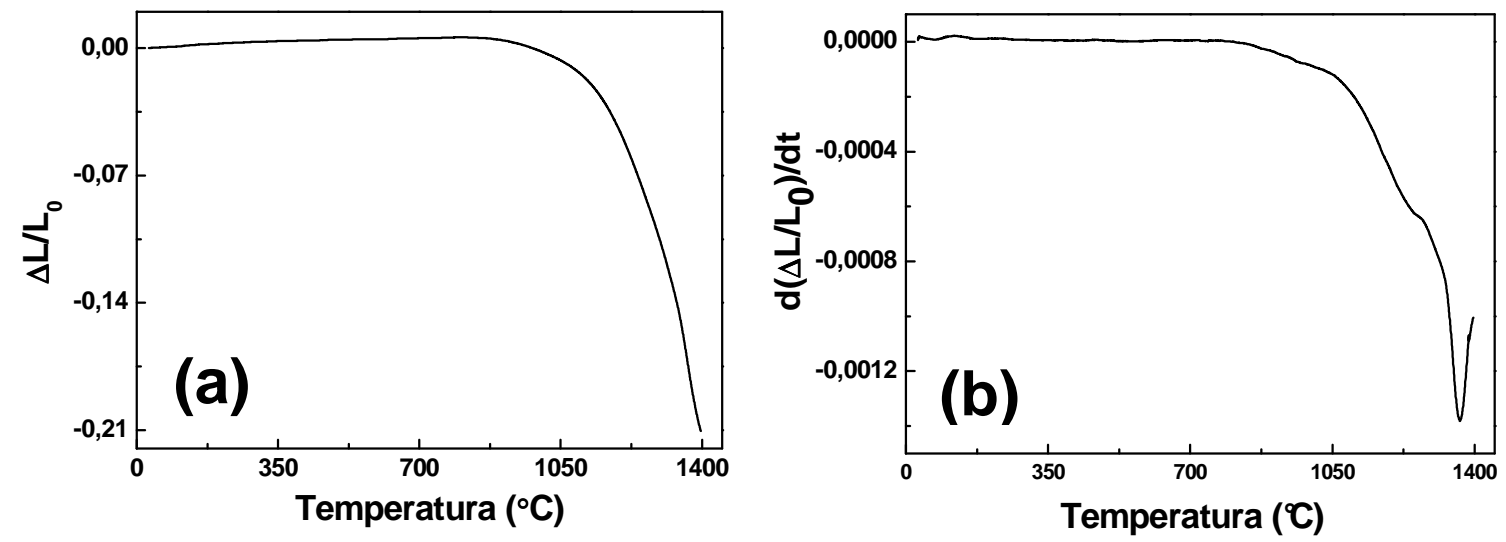

Figure 17 - Curvas TD(a) e DTD (b) de retração do compósito obtido pelo método de sintese por coprecipitação durante o aquecimento e processo de sinterização, com temperatura final de sinterização de $1400^{\circ} \mathrm{C}$

A superfície polida da amostra conformada por prensagem uniaxial e sinterizada a $1500^{\circ} \mathrm{C}$ por uma hora, apresentada na Fig. 18 confirma a homogeneidade da distribuição dos grãos de NiO na matriz cerâmica de YSZ

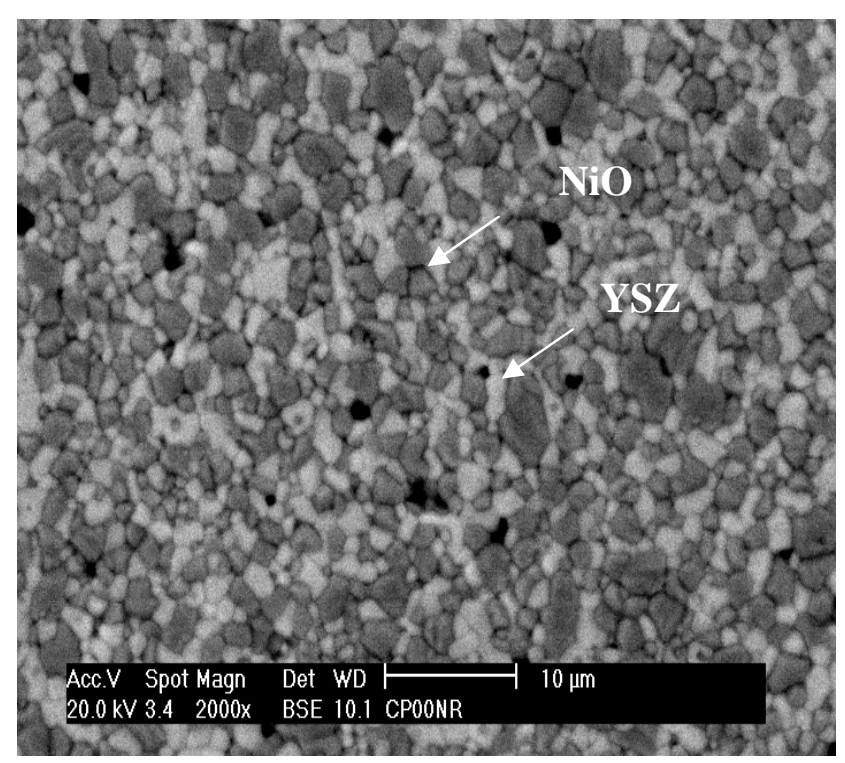

Figura 18 - Micrografia (MEV) da superfície polida e tratada termicamente de amostra cerâmica de NiO-YSZ, conformada por prensagem uniaxial e sinterizada a $1500^{\circ} \mathrm{C}$ por 1 hora, cujos pós de partida foram sintetizados por coprecipitação. 
Na Fig. 19 são apresentadas as curvas TG/DTG e $T$ correspondentes à redução do NiO a Ni no corpo cerâmico NiO-YSZ. A amostra foi aquecida, sob atmosfera de $\mathrm{H}_{2}$, a $20{ }^{\circ} \mathrm{C}$. min $^{-1}$ com isoterma de 60 minutos a $900{ }^{\circ} \mathrm{C}$. Observase que até a temperatura de $4600^{\circ} \mathrm{C}$ ○ NiO não sofre redução. A partir dessa temperatura a taxa de redução do $\mathrm{NiO}$ para $\mathrm{Ni}^{\circ}$ é de aproximadamente 1,0 $\mathrm{mg} \cdot \mathrm{min}^{-1}$, apresentando um comportamento linear até a temperatura de $900{ }^{\circ} \mathrm{C}$. A taxa máxima de redução ocorre na temperatura de $620^{\circ} \mathrm{C}$, determinada a partir da curva DTG, e o processo de redução se completa na isoterma de $900{ }^{\circ} \mathrm{C}$ após 57 minutos de ensaio. Depois de terminado $\mathrm{O}$ processo de redução na superfície, a frente da reação avança em direção ao interior dos aglomerados e a taxa de redução diminui drasticamente devido à formação de cristalitos de níquel na superfície dos óxidos durante o processo de redução. Essa camada metálica faz com que a superfície dos óxidos seja cada vez menos acessível, dificultando a entrada do gás hidrogênio e saída de moléculas de água da superfície dos grãos de óxido de níquel [113].

A densidade relativa e porosidade, calculadas conforme a norma ASTM standard C20-00, da amostra reduzida (CPR1A) apresentada na Tab. 9 e Fig. 20 correspondem à amostra submetida à atmosfera redutora. A porosidade introduzida após a redução corresponde ao volume de oxigênio do níquel presente nos precursores. Amostra com 56\% em massa de NiO apresenta uma porosidade de $23 \%$ após a redução. Pelos resultados apresentados na Tab. 8 observa-se uma distribuição homogênea das fases e baixa porosidade, porém é necessário adicionar formador de poros uma vez que a condição ideal é que o compósito apresente uma porosidade inicial de $10-20 \%$ 

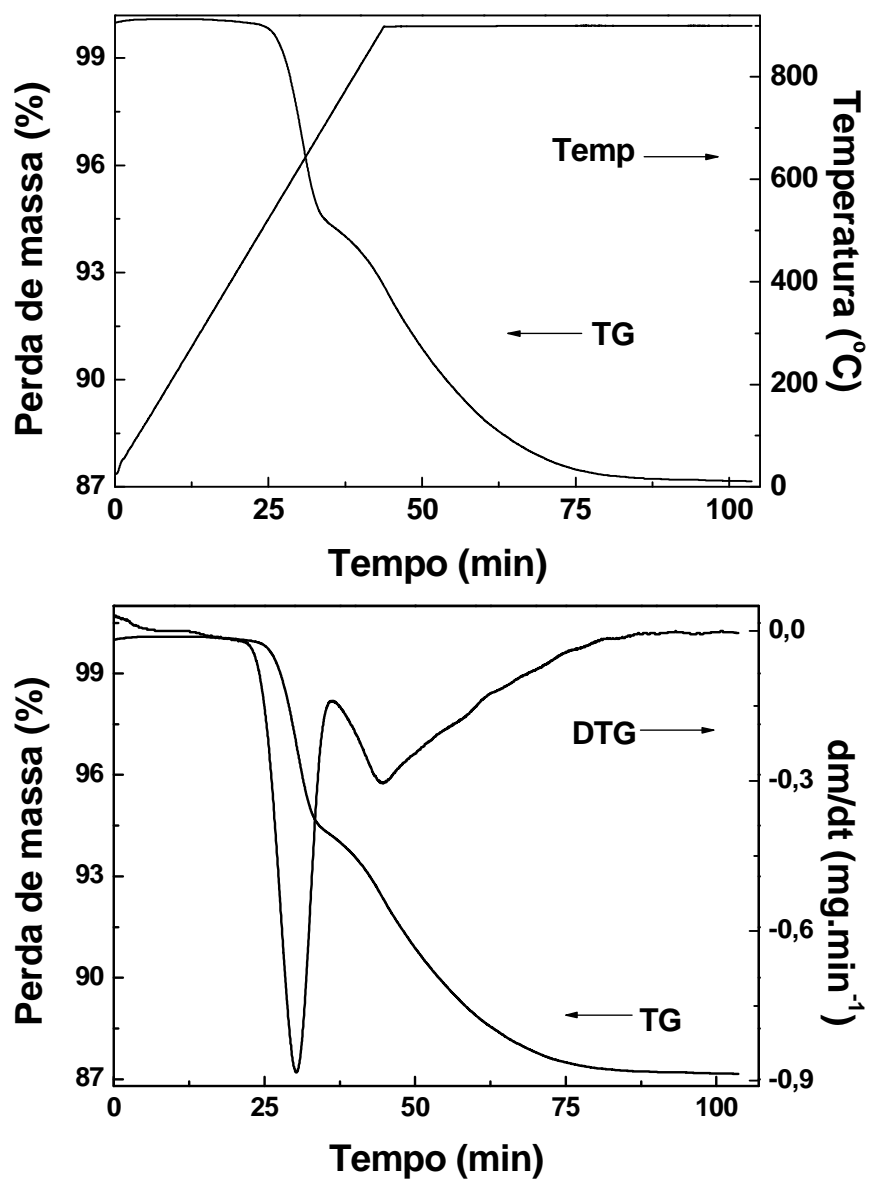

Figura 19 - Curvas TG/DTG e T obtidas a $20{ }^{\circ} \mathrm{C} / \mathrm{min}$ c om $60 \mathrm{~min}$ a $900^{\circ} \mathrm{C}$ e sob atmosfera de $\mathrm{N}_{2}\left(67 \mathrm{~mL} \cdot \mathrm{min}^{-1}\right)$ e $\mathrm{H}_{2}$ (33 $\mathrm{mL} \cdot \mathrm{min}^{-1}$ ) do corpo cerâmico obtido por coprecipitação.

Tabela 9 - Comparação dos valores de porosidade e densidade aparente entre as amostras não reduzida (CP00NR). E amostra reduzida (CPR1A)

\begin{tabular}{cccc}
\hline Amostra & $\begin{array}{c}\text { Densidade aparente } \\
\left({\left.\mathrm{g} . \mathrm{cm}^{-3}\right)}^{3}\right.\end{array}$ & $\begin{array}{c}\text { Densidade relativa } \\
(\%)\end{array}$ & $\begin{array}{c}\text { Porosidade } \\
(\%)\end{array}$ \\
\hline \hline CP00NR & 6,35 & 95,8 & 0,79 \\
CPR1A & 5,56 & 83,9 & 23,0 \\
\hline \hline
\end{tabular}




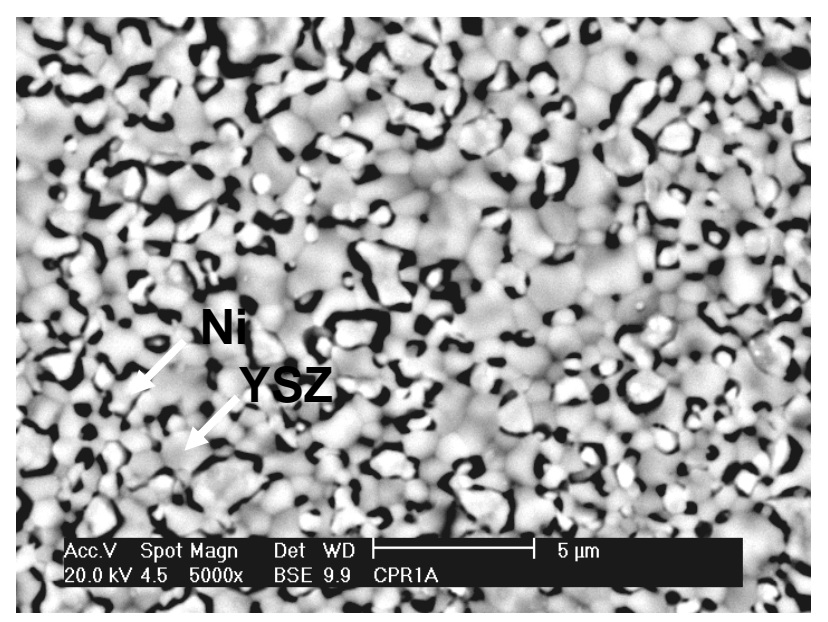

Figura 20 - Micrografia (MEV) da superfície polida da amostra cerâmica de NiO-YSZ reduzida em atmosfera de $4 \% \mathrm{H}_{2}$ em balanço com argônio. Vazão de $100 \mathrm{~mL} \cdot \mathrm{min}^{-1}$

\section{V.2 - Método da mistura de pós}

Os pós de $8,5 \mathrm{YSZ}$, calcinados a $800^{\circ} \mathrm{C}$ por 1 hora e submetidos à moagem em moinho de bolas por 16 horas, apresentam área de superfície específica de 53,6 $\mathrm{m}^{2} \cdot \mathrm{g}^{-1}$ e tamanho médio de aglomerado de 0,09 $\mu \mathrm{m}$. O NiO, por sua vez, foi submetido à moagem de alta energia por 10 horas para o menor tamanho de aglomerado. Neste último caso, a área superficial alcançada foi de 13,3 $\mathrm{m}^{2} \cdot \mathrm{g}^{-1}$ e tamanho médio de aglomerado de 9,0 $\mu \mathrm{m}$.

Da análise dos resultados preliminares obtidos e observação experimental, verificou-se que com o emprego do método de mistura de pós houve sedimentação diferencial das partículas, sendo que o $\mathrm{NiO}$ sedimentou primeiro devido à maior densidade e tamanho de partícula.

A partir dos resultados apresentados na Fig. 21 observa-se que não há uma faixa de $\mathrm{pH}$ que favoreça a estabilização simultânea das distintas espécies. $\mathrm{Na}$ faixa de $\mathrm{pH}$ estudada, as partículas de $\mathrm{NiO}$ apresentam condição de dispersão estável para valores de $\mathrm{pH}$ entre 6,0 e 9,0, atingindo um valor máximo de potencial zeta de $38,4 \mathrm{mV}$ para $\mathrm{pH} 6,7$, enquanto as partículas de YSZ são estáveis em $\mathrm{pH}>10,0$. Os valores de $\mathrm{pH}$ do ponto isoelétrico (p.i.e.) dos pós de $\mathrm{NiO}$ e YSZ, são respectivamente 10,5 e 6,9. No estudo apresentado por Ramanathan et al. [114] a faixa de pH para estabilização simultânea dos óxidos ficou entre 9 e 11 na faixa básica e entre 3 e 4 na faixa ácida. O tamanho médio de partículas dos óxidos (NiO e YSZ ) utilizados neste 
experimento foi de 2,2 $\mu \mathrm{m}$. Han et al. [115] obtiveram os valores de $\mathrm{pH}$ do ponto isoelétrico (p.i.e.) para $\mathrm{YSZ}$ em $\mathrm{pH}=7,54 \mathrm{e} \mathrm{pH}=6,24$ para $\circ \mathrm{NiO}$ e a melhor condição de estabilidade para o compósito NiO-YSZ em pH > 6,0.

Em função desses resultados foi necessário fazer um estudo de estabilidade das suspensões aquosas de $\mathrm{NiO}$ e YSZ, em função da concentração de dispersante. Quando é adicionado o poliacrilato de amônio na suspensão ocorre um deslocamento do p.i.e. dos pós para região ácida devido à adsorção do dispersante na superfície dos pós. A não alteração ou um deslocamento muito lento do valor de potencial zeta é um indicativo que a adsorção do dispersante atingiu o seu valor máximo.

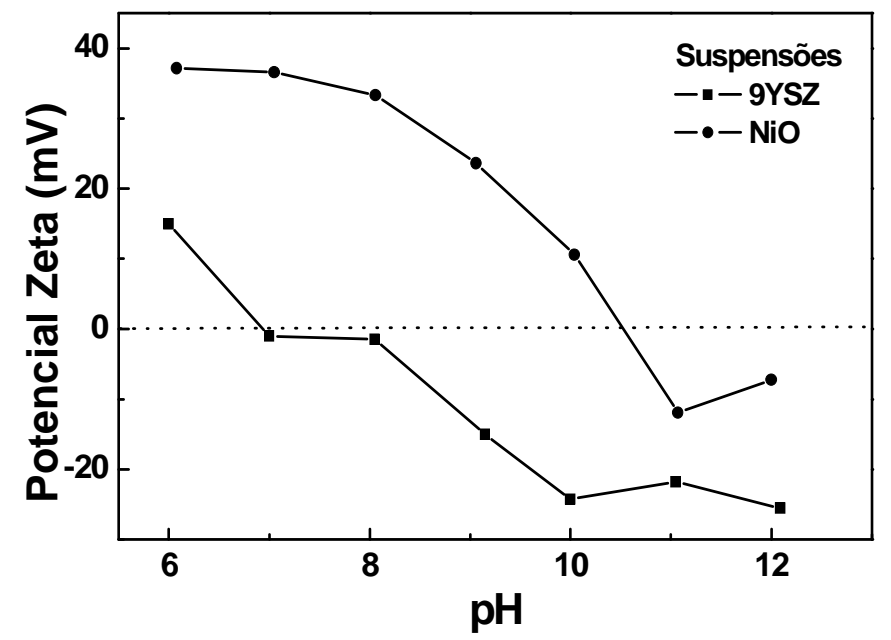

Figura 21- Potencial zeta de suspensões de NiO e YSZ, sem adição de aditivos, em função do $\mathrm{pH}$.

O maior valor de potencial zeta, $65,8 \mathrm{mV}$ em $\mathrm{pH}$ 9,0, foi obtido para uma concentração de dispersante de 1,6\% para os pós de NiO, Fig. 22.a. Contudo, em relação à adição de $0,8 \%$ de dispersante este valor máximo de potencial zeta representa um aumento pouco significativo deste parâmetro. Provavelmente a concentração de $0,8 \%$ de dispersante foi suficiente para atingir o ponto de adsorção máximo, para um intervalo de pH entre 8 e 9 . No caso das suspensões de 8,5YSZ, apresentadas na Fig. 22.b, a melhor condição de dispersão foi alcançada para uma concentração de $0,4 \%$ de dispersante em $\mathrm{pH} 8,0$.

Com a adição de dispersante as partículas de $\mathrm{NiO}$ e YSZ apresentam cargas negativas em uma ampla faixa de $\mathrm{pH}$, atingindo valores máximo de potencial zeta em $\mathrm{pH}$ entre 8 e 9. 
A partir destes resultados, definiu-se a concentração de dispersante, empregada para estabilização de uma suspensão aquosa com 30\% em massa de mistura de sólidos de NiO-YSZ, em 0,8\%, em relação ao volume de pó seco. Embora nesta concentração de sólidos a distância entre partículas seja grande, ocorre a interação entre as mesmas e a suspensão passa a ter um comportamento não newtoniano. Os valores de $\mathrm{pH}$ das suspensões foram ajustados entre 8 e $10 \mathrm{com} \mathrm{NH}_{4} \mathrm{OH}$.
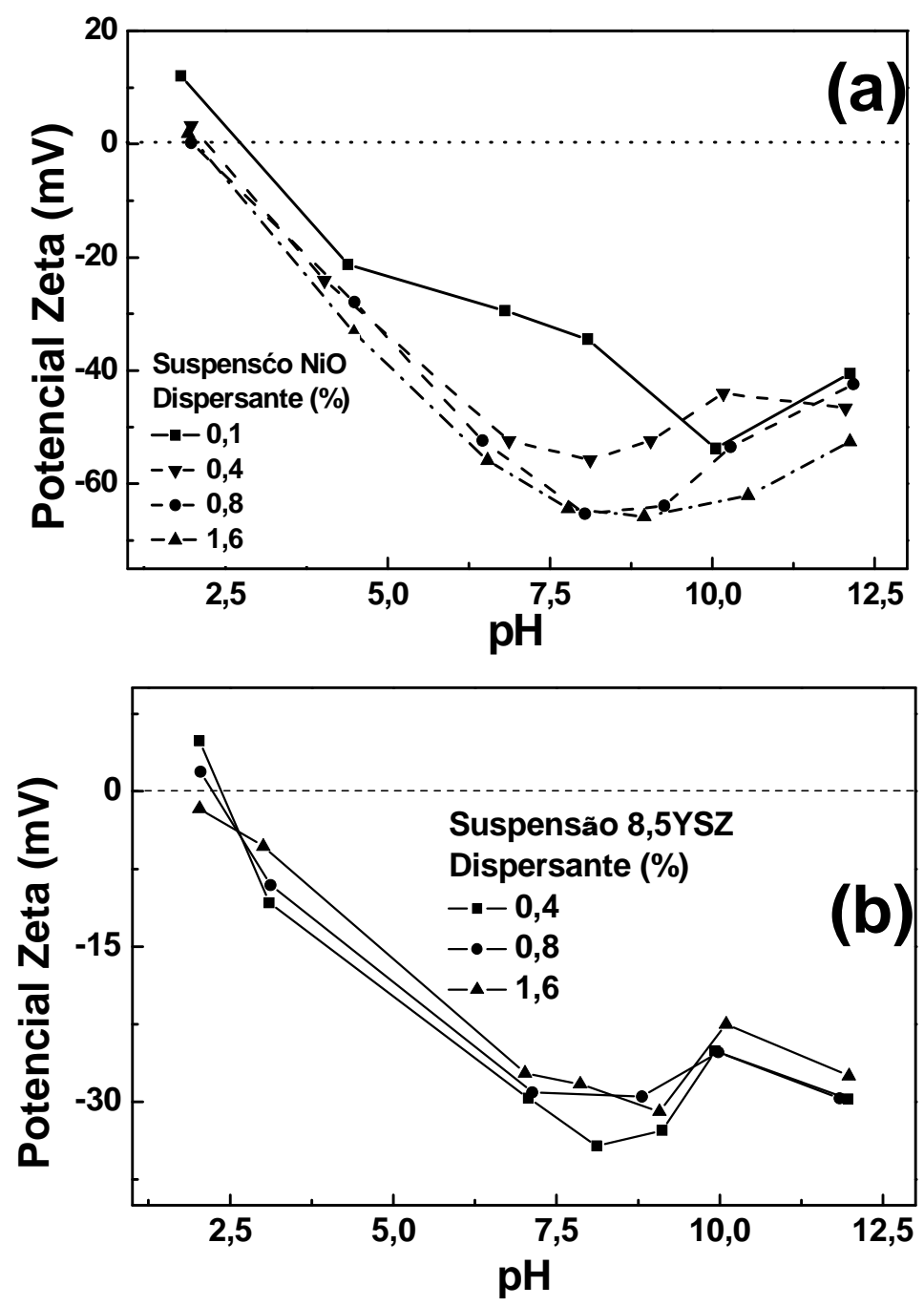

Figura 22 - Influência do dispersante nos valores do potencial zeta em função do pH de suspensões de $\mathrm{NiO}$ (a) de YSZ (b)

Conforme os gráficos apresentados na Fig.23, verifica-se que a viscosidade aumenta com o aumento do $\mathrm{pH}$ da suspensão e que há um aumento na tensão de cisalhamento, no intervalo de taxa de cisalhamento estudada, com o aumento do $\mathrm{pH}$ da suspensão. Para uma taxa de 
cisalhamento de $40 \mathrm{~s}^{-1}$, os valores de viscosidade para $\mathrm{pH}=8,9$ e 10 foram, respectivamente 25,8; 42,6 e 69,2 m.Pa.s. Observou-se também que a variação da viscosidade em relação ao $\mathrm{pH}$ da suspensão NiO-YSZ apresenta 0 mesmo comportamento em relação aos valores de potencial zeta individuais dos pós $\mathrm{NiO}$ e YSZ, isto é, com o aumento dos valores de $\mathrm{pH}$ houve um aumento nos valores de viscosidade. Com base nos resultados acima apresentados foram definidas as seguintes condições para preparação de suspensões homogêneas de NiO-YSZ: $\mathrm{pH}=8$; (dispersante) $=0,8 \%$ em massa; $($ sólido) $=30 \%$ em massa; $(\mathrm{NiO}) /(\mathrm{YSZ})=42 / 58$.
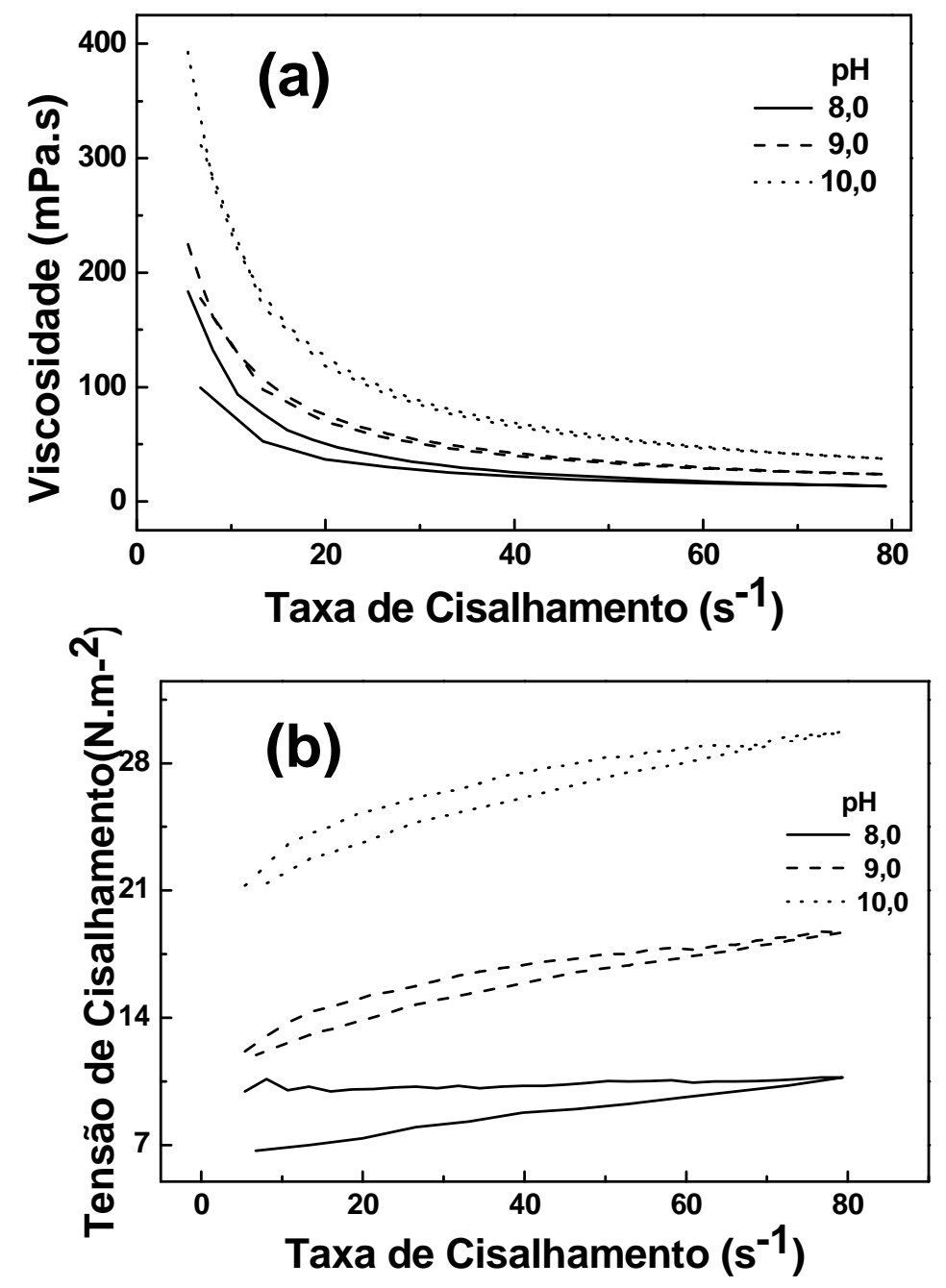

Figura 23 - Influência do pH na tensão de cisalhamento (a) e viscosidade (b) em função taxa de cisalhamento, de suspensões de NiO-YSZ 
$\mathrm{Na}$ Fig.24 é apresentado o difratograma de raios $X$, onde são identificadas cada uma das fases que constituem a mistura de pós de NiO-YSZ, obtidas após a secagem.

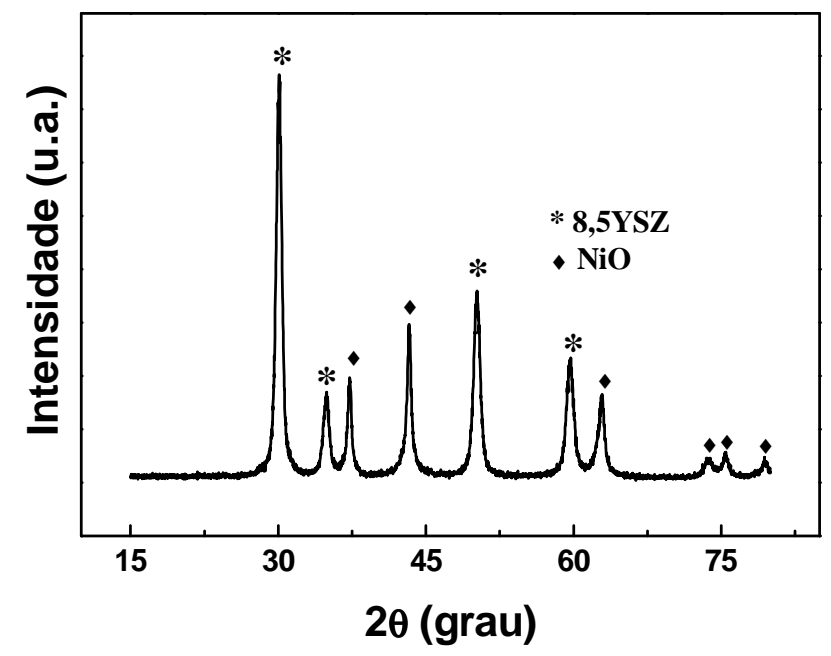

Fig. 24 - Difratograma de raios $X$ da mistura de pós de NiO-YSZ

A micrografia eletrônica de varredura relativa à mistura de pós a ser utilizada na sinterização da amostra é apresentada na Fig 25.a, observa-se uma mistura relativamente homogênea dos pós. Na Fig 25.b é apresentada uma micrografia da superfície polida e tratada termicamente da amostra conformada por prensagem uniaxial e sinterizada a $1500 \stackrel{\circ}{\circ}$ por uma hora, que indica a homogeneidade dos grãos de NiO na matriz cerâmica de YSZ. Wang et al.[101] estudaram a influência do tamanho de partículas nos parâmetros de redução do anodo Ni-YSZ adotando a técnica de mistura de pós. Nestes experimentos foram utilizados pós finos $(\sim 2 \mu \mathrm{m})$ de NiO e YSZ em uma das composições, e com distribuição bi-modal de partículas de $\mathrm{NiO}(11 \mu \mathrm{m}$ e $5 \mu \mathrm{m})$ e YSZ (4 $\mu \mathrm{m}$ e $1 \mu \mathrm{m}$ ) em uma segunda composição.

Nas amostras em que foram utilizadas pós de $\mathrm{NiO}$ com maior tamanho de partículas e YSZ finos observou-se maior porosidade em relação às amostras preparadas com pós de menor granulometria e, consequentemente, uma menor resistência mecânica. Tietz et al. [38] ao avaliar pós de NiO de diversas procedências, em relação a suas propriedades, para ser aplicado como anodo em SOFC também concluíram que partículas grandes de $\mathrm{NiO}$ podem provocar baixa condutividade do anodo da SOFC. 
Conforme observado na Fig. 25.b, apesar da distribuição de fases de $\mathrm{NiO}$ e YSZ ser relativamente homogênea, a tendência à aglomeração do $\mathrm{NiO}$ pode provocar a formação de poros grandes e prejudicar na resistência mecânica do anodo e na conectividade das fases (Ni e YSZ, entre si). Estes resultados comprovam que é necessário adotar outra técnica de moagem que seja eficiente para diminuir o tamanho de partículas para menos de 2,0 $\mu \mathrm{m}$.
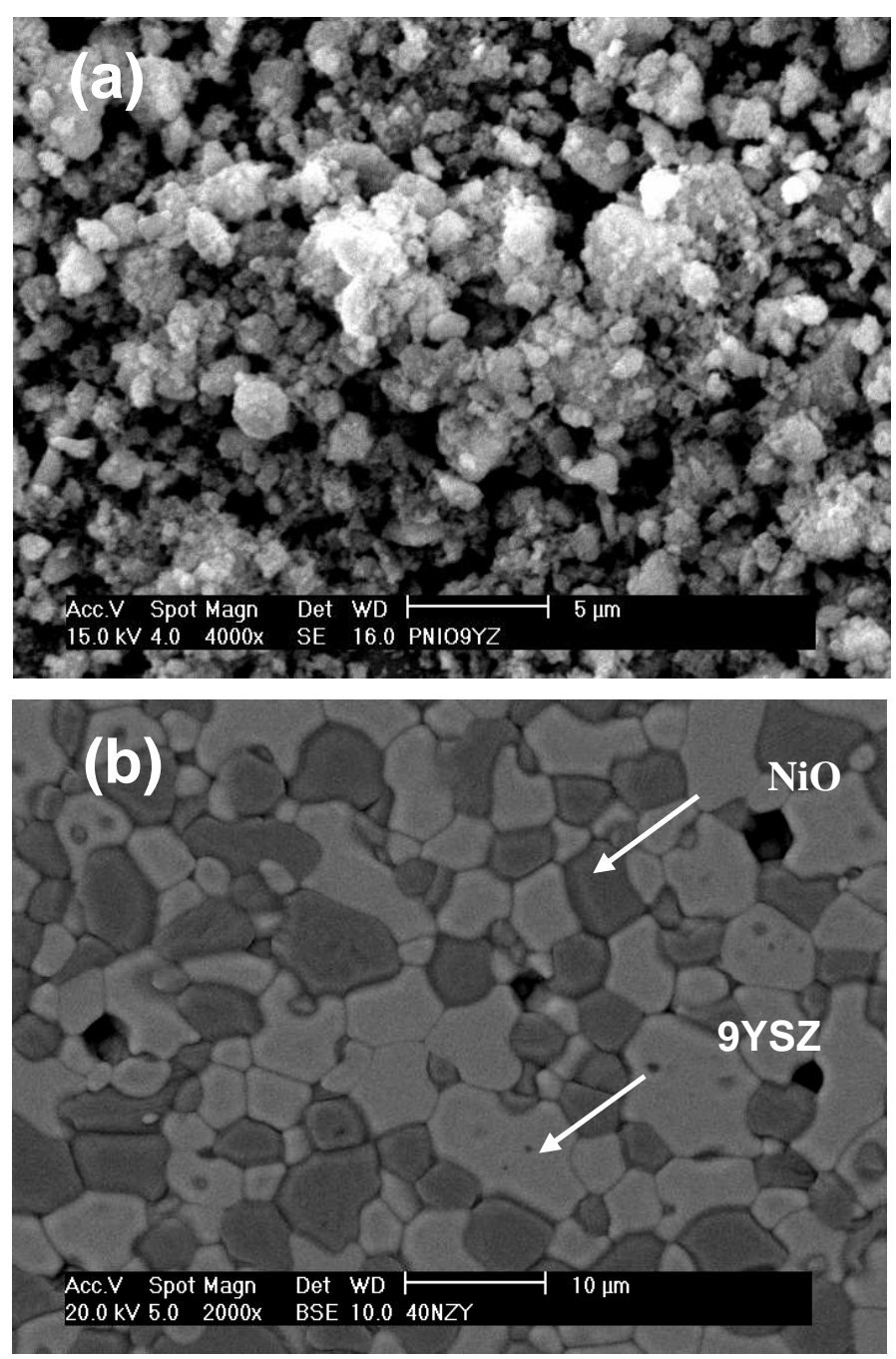

Figura 25 - (a) Micrografias (MEV) da mistura de pós de NiO- YSZ e (b) da superfície polida da amostra cerâmica de NiO-8,5YSZ conformada, por prensagem uniaxial e sinterizada a $1500^{\circ} \mathrm{C}$ por 1 hora.

No processo de redução a alta temperatura $\left(800-900{ }^{\circ} \mathrm{C}\right)$, a água formada é rapidamente removida através dos poros e ao mesmo tempo o 
átomo de níquel difunde rapidamente na superfície do NiO. Quando o aglomerado de $\mathrm{NiO}$ atinge um tamanho suficientemente grande para iniciar a dissociação do hidrogênio, a redução é acelerada auto cataliticamente [116].

A fração de $\mathrm{NiO}$ reduzida é determinada a partir da diferença da massa inicial e final em função do tempo. Esta perda de massa corresponde à massa de oxigênio liberado na redução.

As curvas apresentadas na Fig.26 exibem dois estágios de redução: no primeiro estágio a taxa de conversão de $\mathrm{NiO}$ para $\mathrm{Ni}^{\circ}$ é elevada, sendo praticamente linear. No segundo estágio, a taxa de redução diminui continuamente até a fração de $\mathrm{NiO}$ reduzido atingir valores próximos a $85 \%$. Um dos fatores que contribui para que não se atinja a completa redução do óxido é a formação de uma camada de níquel metálico na superfície dos óxidos durante o processo de redução. Essa camada metálica faz com que sejam cada vez menos acessíveis e a taxa de redução mais lenta, dificultando a saída de moléculas de água (que são formadas na reação de redução do $\mathrm{Ni}$ ) dos grãos de $\mathrm{NiO}$ [113].

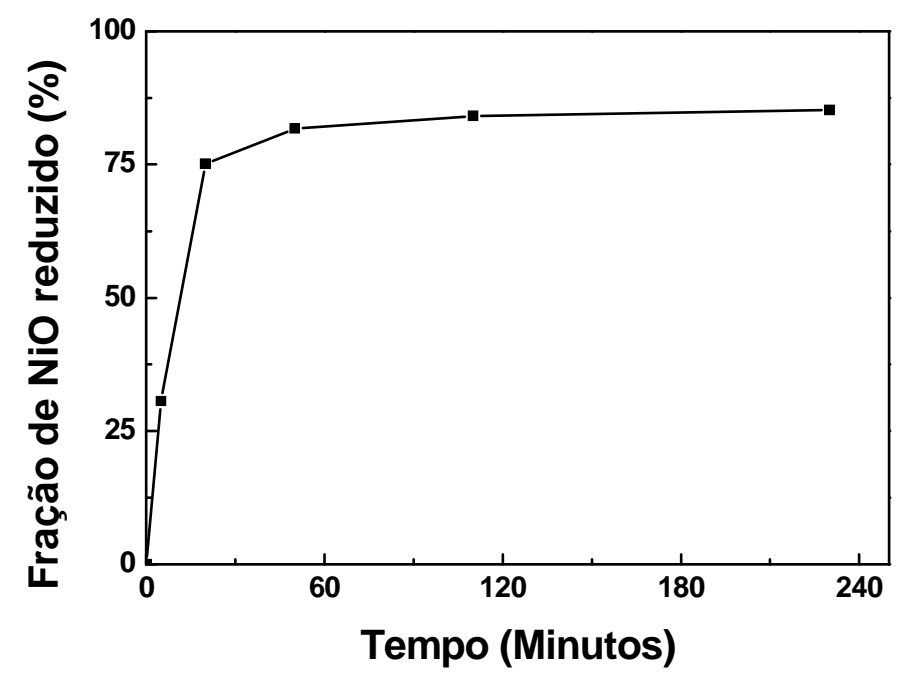

Figura 26 - Fração de NiO reduzido na cerâmica NiO-YSZ a $900^{\circ} \mathrm{C}$ obtida por mistura de pós em função do tempo de redução em atmosfera de hidrogênio

$\mathrm{Na}$ Fig.27 é apresentada a curva de porosidade das amostras $\mathrm{NiO}$ (52\% em massa)/YSZ após a redução, que foi determinada de acordo com ASTM C20-00 em função da fração de NiO reduzido. Pela curva observa-se 
que há um aumento da porosidade em função do aumento da fração de $\mathrm{NiO}$ reduzido. A porosidade introduzida pela redução do $\mathrm{NiO}$ foi de aproximadamente $18 \%$, valor este muito abaixo do valor aceitável, que é acima de $30 \%$, para um bom desempenho do anodo [25].

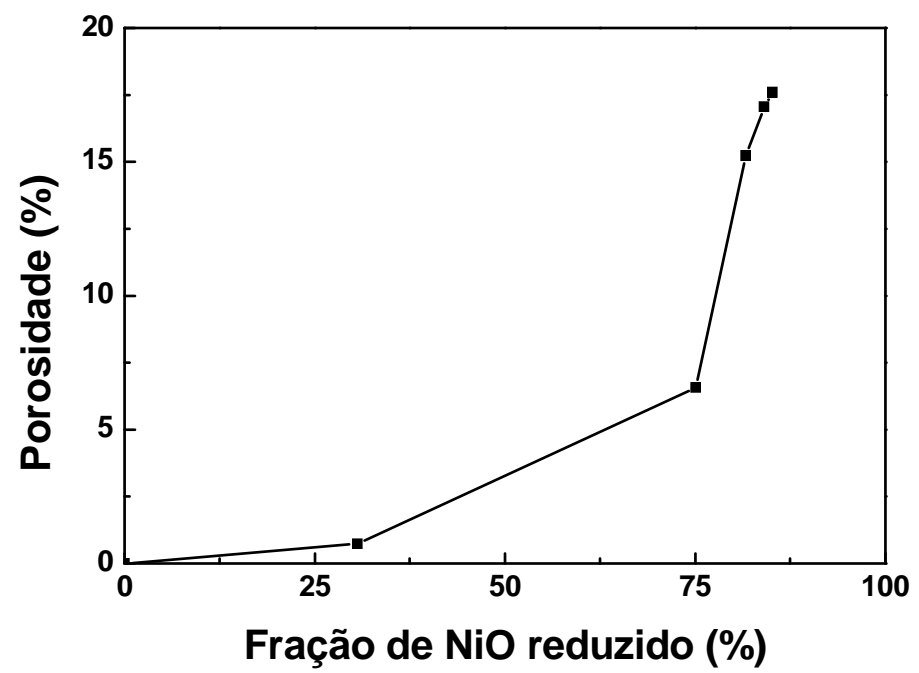

Figura 27- Porosidade da cerâmica $\mathrm{NiO}$ (52\% em massa)/YSZ obtida por mistura de pós em função da fração de $\mathrm{NiO}$ reduzido

A Fig.28 mostra micrografias óticas das secções transversais do compósito NiO-YSZ obtida por mistura de pós. Pode-se verificar a evolução do processo de redução na superfície dos óxidos em função do tempo, em atmosfera redutora a $900^{\circ} \mathrm{C}$. As faixas mais escuras na extremidade da amostra (b) correspondem à parte reduzida do compósito, enquanto a região central mais clara corresponde à parte não reduzida.

Nas micrografias obtidas por microscopia eletrônica de varredura (Fig.29.a) a fase cerâmica YSZ é representada pela cor cinza claro, a fase NiO é representada pelo cinza escuro e a cor preta indica os poros. Na Fig.29.b é possível observar a presença de aglomerados de $\mathrm{NiO}$ (cinza escuro) envolvidos por uma camada de níquel metálico (cinza claro), identificado na micrografia. É a presença destes aglomerados maiores que faz com que a redução do $\mathrm{NiO}$ não seja total. Observa-se ainda uma distribuição relativamente homogênea das fases cerâmica e metálica. Na Fig.29.c pode-se 
observar que o tamanho médio dos aglomerados das fases metálica (cinza escuro) e cerâmica (cinza claro) apresenta praticamente as mesmas dimensões e também a presença de poros maiores (preto).
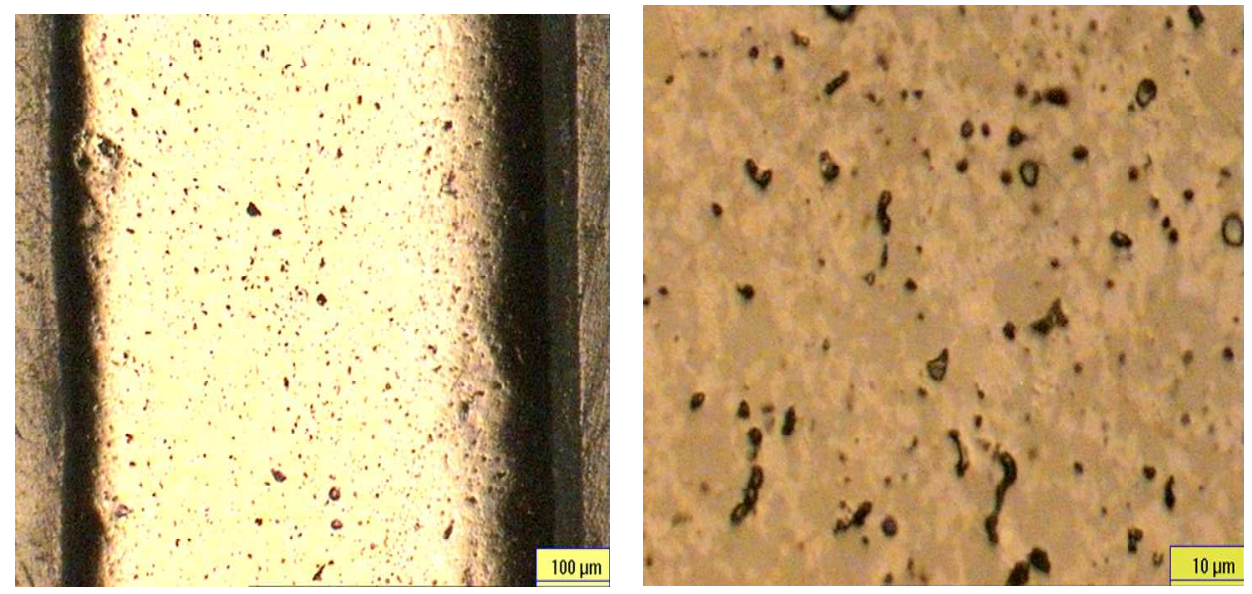

(a)
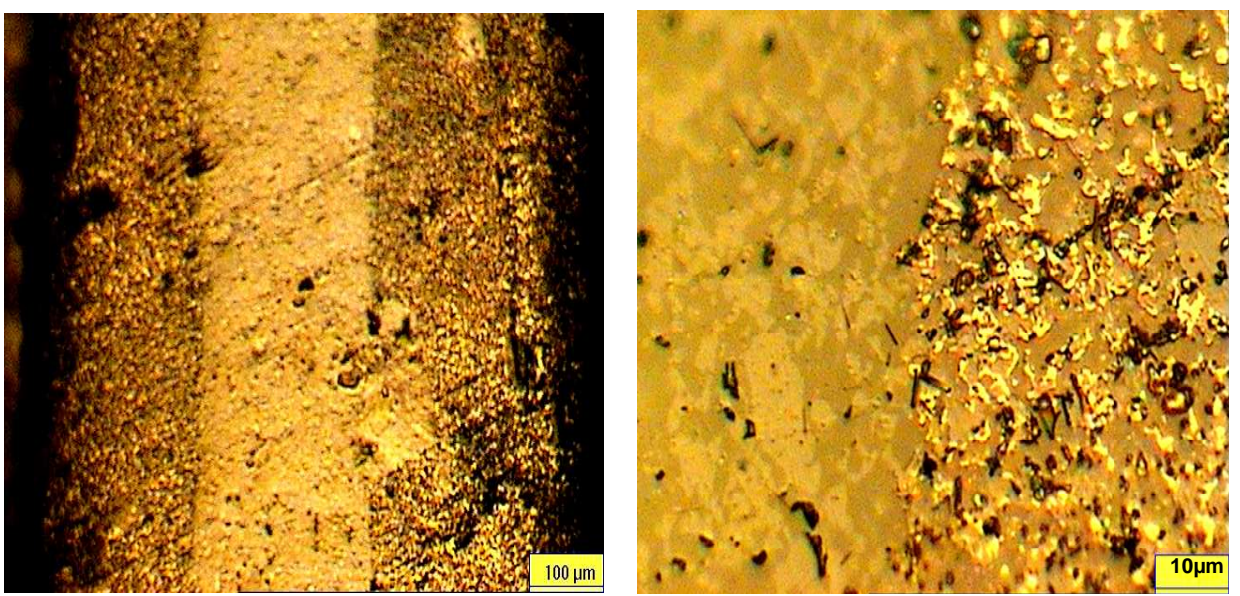

(b)
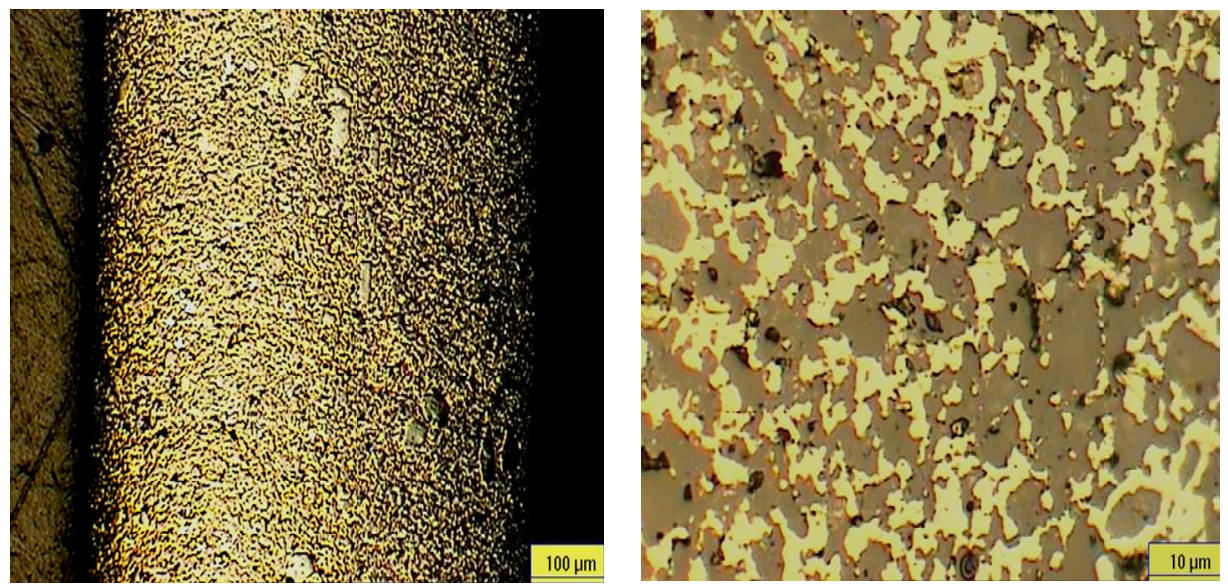

(c)

Figura 28 - Micrografias óticas das secções transversais do compósito NiO -YSZ obtidas por mistura de pós: antes da redução (a), após redução a 900 $\stackrel{\circ}{\circ}$ por 15 minutos(b) e 60 minutos (c). 


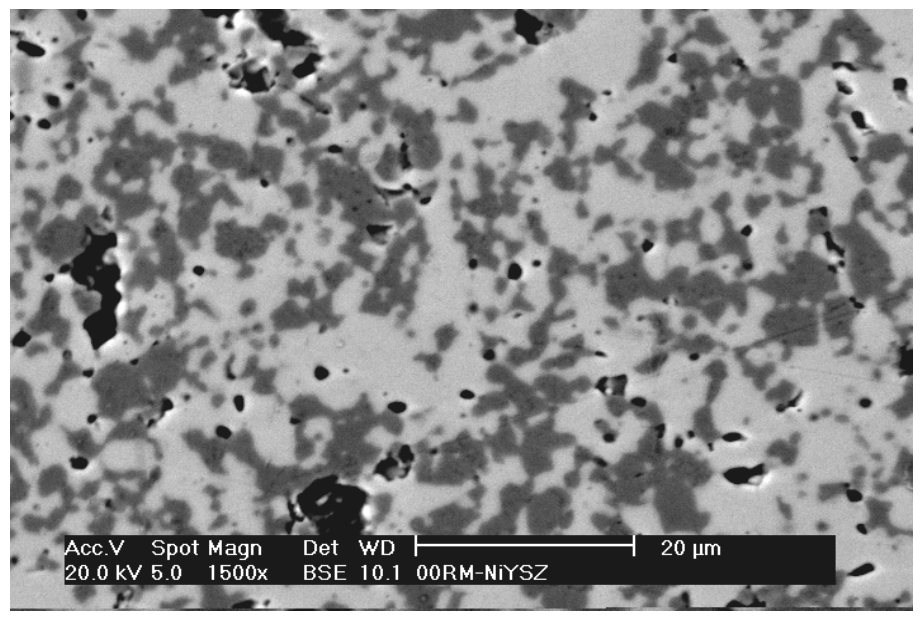

(a)

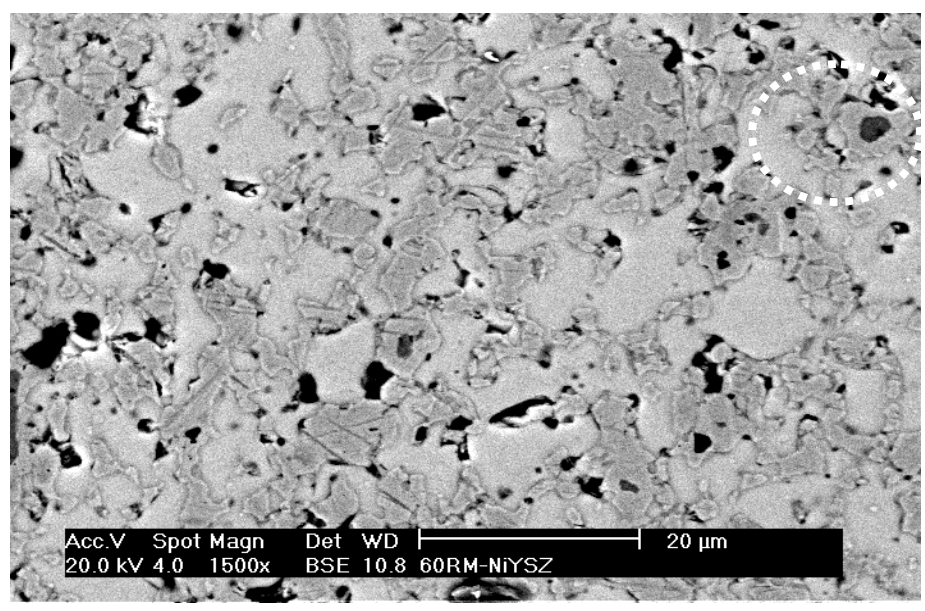

(b)

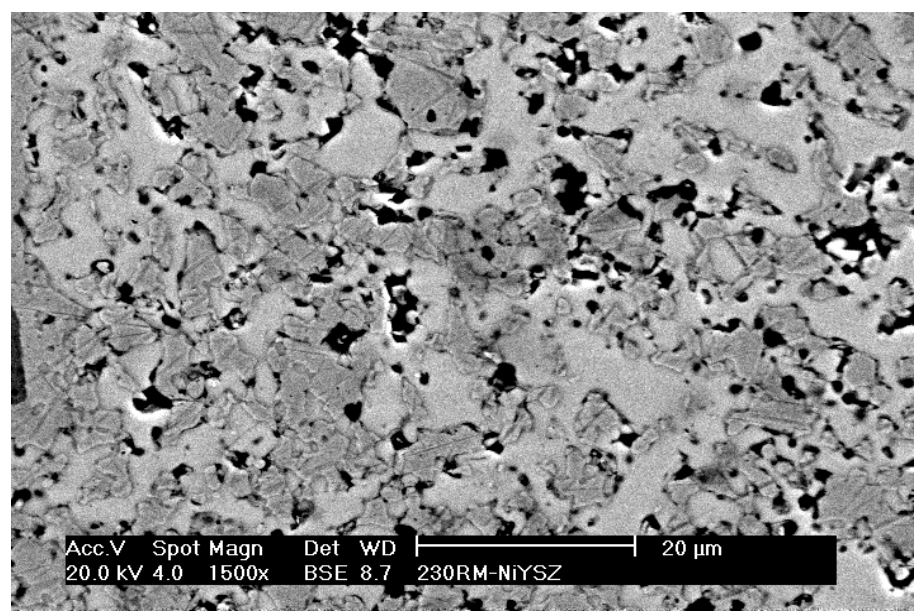

(c)

Figura 29 - Micrografias MEV das superfícies polidas e tratadas termicamente das amostras cerâmicas NiO-YSZ obtidas por mistura de pós: sinterizadas a $1500^{\circ} \mathrm{C}$ por 1 hora (a), redução a $900^{\circ} \mathrm{C}$ por 1 hora (b) e 2 horas (c).

Na Fig. 30 são apresentados os difratogramas de raios $X$ relativos ao compósito NiO-YSZ após sinterização e redução. Observa-se que com o aumento do tempo de redução desaparecem os picos de $\mathrm{NiO} e$ 
simultaneamente surgem picos de $\mathrm{Ni}$. Todo $\mathrm{NiO}$ é reduzido a $\mathrm{Ni}^{0}$ após 30 minutos de redução. Para ilustrar esta afirmação, selecionou-se o par NiO, $43,29^{\circ}(2 \theta)$ e $\mathrm{Ni} 44,50^{\circ}$ (20) por apresentar a maior intensidade. As reflexões

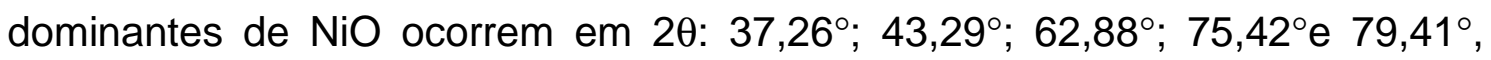
enquanto para o $\mathrm{Ni}$ os picos dominantes são em $2 \theta: 44,50^{\circ} ; 51,86^{\circ}$ e $76,39^{\circ}$. $\mathrm{Na}$ transformação de $\mathrm{NiO}$ para Ni não foi observado nenhum pico característico de uma outra fase intermediária.

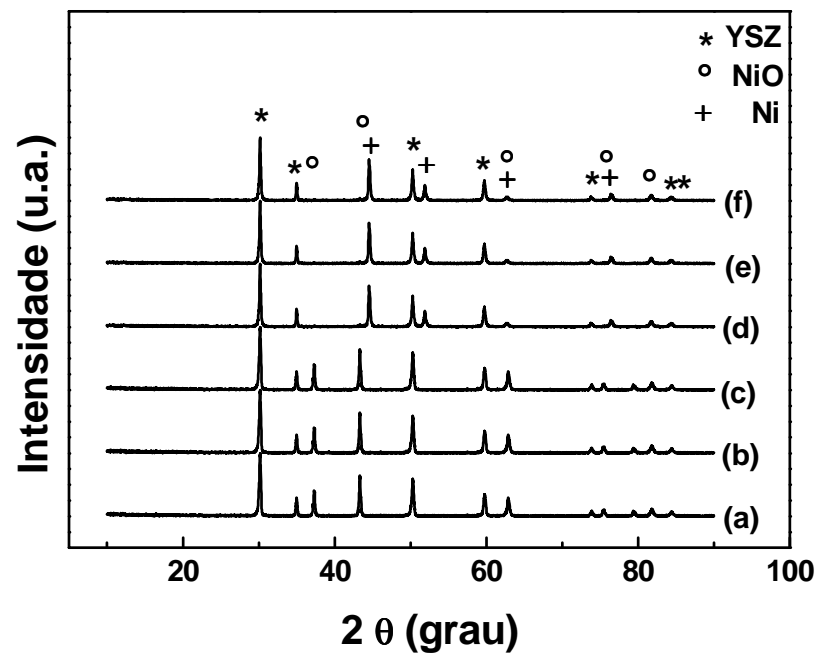

Figura 30 - Difratogramas de raios $X$ dos compósitos NiO-YSZ obtido por mistura de pós, após sinterização (a), submetidos a redução a $900^{\circ} \mathrm{C}$ por 05 minutos (b), 15 minutos (c), 30 minutos (d), 60 minutos (e) e 120 minutos (f)

\section{V.3 - Síntese por combustão}

Na síntese por combustão, é o tipo e a quantidade de combustível que irá determinar a quantidade de calor liberado pelo sistema e, consequentemente, as propriedades físicas dos pós obtidos. A formação das fases cristalinas de $\mathrm{NiO}, \mathrm{YSZ}$ e $\mathrm{Ni}^{\circ}$ depende do tipo e quantidade de combustível adicionado na solução aquosa precursora contendo os cátions de interesse. No processo de combustão da mistura sais de nitratos dos metais uréia, os nitratos dos elementos metálicos se decompõem na forma óxidos nitrosos e óxidos, enquanto a uréia se decompõe em $\mathrm{NH}_{3}, \mathrm{HCNO}, \mathrm{CO}_{2}$ e $\mathrm{H}_{2} \mathrm{O}$. Durante $\mathrm{O}$ aquecimento da solução ocorrem inúmeras reações de decomposição envolvendo a formação de inúmeros complexos que ao se misturarem sofrem auto-ignição $[117,118]$. 
Os pós resultantes foram caracterizados por difratometria de raios $\mathrm{Xe}$ os resultados são apresentados na Fig. 31. A adição de uréia na quantidade estequiométrica não foi suficiente para uma reação completa. Este fato provavelmente está relacionado com a decomposição dos nitratos durante o aquecimento da solução contendo os precursores, que pode alterar a relação entre o combustível e oxidante. Outro fator que pode influenciar para que autoignição não ocorra é que, apesar da reação de formação do compósito e decomposição da uréia ser altamente exotérmica, a temperatura não é suficientemente alta para provocar a combustão [77]. Nos difratogramas (a) e (b) os pós produzidos apresentam características de um produto de baixa cristalinidade, confirmando a baixa temperatura de reação e tempo de chama de combustão insuficiente para completa cristalização da fase. Por outro lado, sabe-se que temperaturas mais elevadas induzem a uma maior energia de ativação, favorecendo a cristalização, fato este que é comprovado pelos difratogramas (c), (d) e (e).

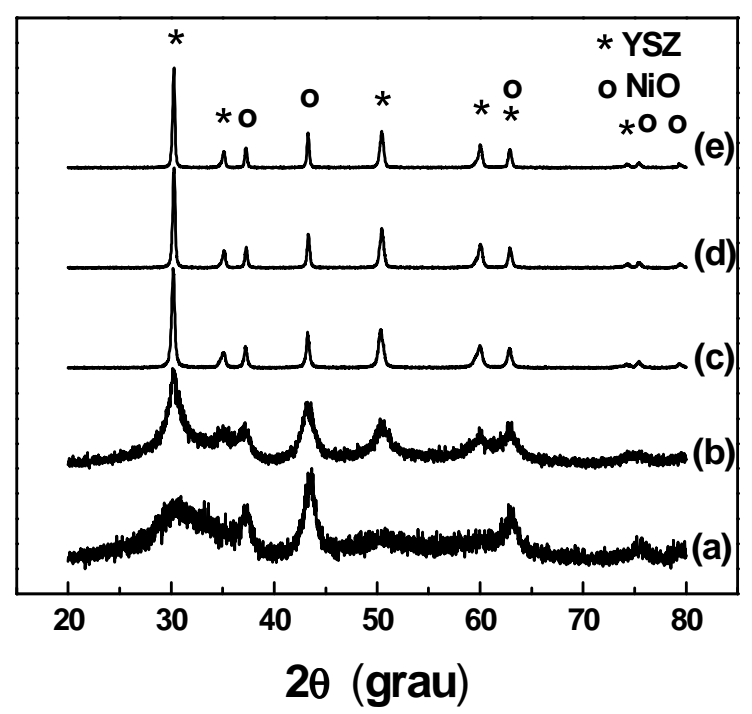

Figura 31 - Difratogramas de raios $X$ dos pós NiO-YSZ produzidos por reação de combustão em função da relação molar uréia/nitrato, $\Phi_{\mathrm{e}} \mathrm{em}$ 1,0 (a); 0,65 (b); 0,57 (c); 0,55 (d) e 0,52 (e)

Em geral, quando o combustível é adicionado em quantidade superior à estequiométrica, maior é a quantidade de calor liberado, afetando as características dos pós que, dependendo da aplicação, pode ter um efeito adverso. Por exemplo, pode ocorrer uma sinterização parcial das partículas 
ativas primárias que foram produzidas durante a combustão, levando à redução da área superficial e aumento do tamanho do cristalito. Efeito contrário a estes pode ocorrer mesmo com o aumento da temperatura, pois quando o conteúdo de combustível aumenta a quantidade de gases liberada também aumenta. Estes gases liberados dissipam o calor de combustão e limitam o aumento da temperatura. Assim, reduzindo a possibilidade de ocorrer à sinterização parcial das partículas primárias, as moléculas de gases facilitam a quebra dos aglomerados primários enquanto escapam [118]. Por outro lado, quando a solução é deficiente em combustível os pós produzidos apresentam uma grande área de superfície específica e consequentemente resultam em partículas de tamanhos nanométricos [119]. Marinsek et al. [61], também obtiveram resultados similares utilizado o ácido cítrico como combustível. $\mathrm{Na}$ Tab. 10 são apresentadas a características físicas dos pós produzidos e a temperatura de chama em função da concentração de uréia.

Tabela 10- Características físicas dos pós obtidos por reação de combustão, em função da relação molar uréia/nitratos

\begin{tabular}{cccccc}
\hline Amostra & $\Phi_{\mathrm{e}}$ & $\begin{array}{c}\text { Area } \\
\text { superficial } \\
\left(\mathrm{m}^{2} \cdot \mathrm{g}^{-1}\right)\end{array}$ & $\begin{array}{c}\text { Temperatura de } \\
\text { reação } \\
\left({ }^{\circ} \mathrm{C}\right)\end{array}$ & coloração & $\begin{array}{c}\text { Densidade } \\
\text { da amostra } \\
\left(\mathrm{g} \cdot \mathrm{cm}^{-3}\right)\end{array}$ \\
\hline \hline CONYZ & 1,0 & 130,34 & ---- & Preta & 4,37 \\
CONYZ1,0 & 0,65 & 87,02 & 865 & Preta & 4,72 \\
CONYZ1,5 & 0,57 & 14,83 & 1151 & Verde & 5,67 \\
CONYZ1,75 & 0,55 & 8,02 & 1283 & Verde & 6,08 \\
CONYZ2,0 & 0,52 & 4,55 & 1329 & verde & 6,00 \\
\hline \hline
\end{tabular}

A Fig. 32 mostra que o maior aglomerado de tamanho médio $(43 \mu \mathrm{m})$ de pós de óxidos foi produzido utilizando-se a relação estequiométrica entre 0 combustível e os nitratos. Quando a quantidade de combustível é adicionada em dobro em relação ao valor estequiometrico, o tamanho médio de aglomerado foi de $38 \mu \mathrm{m}$. O tamanho médio de aglomerado diminui com o aumento da quantidade de combustível utilizado em excesso. 


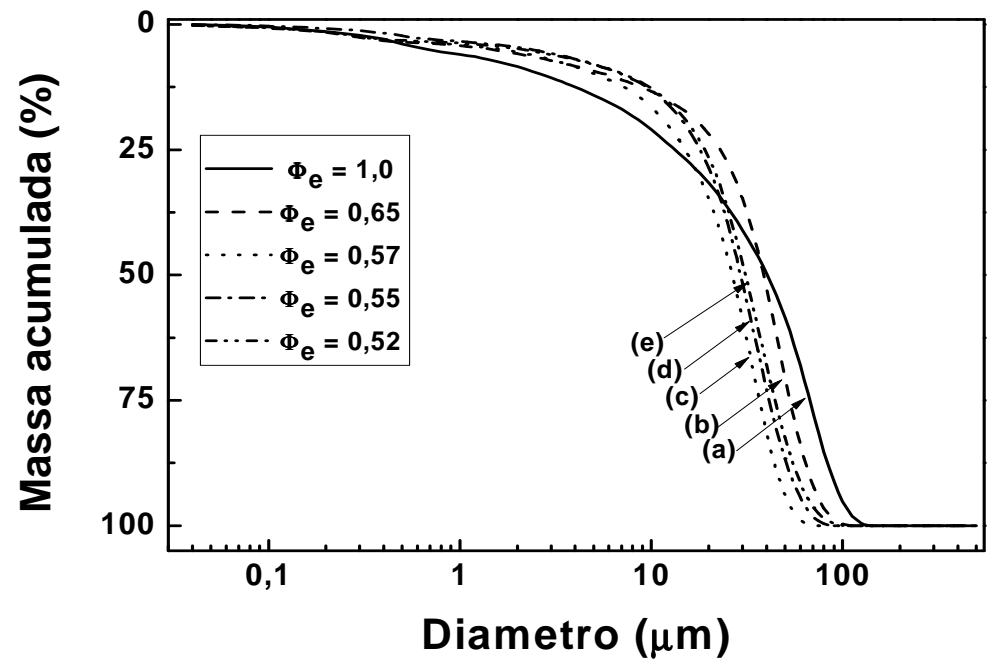

Figura 32 - Distribuição granulométrica dos pós de NiO-YSZ moídos e produzidos por reação de combustão em função da relação molar uréia/nitrato, $\Phi_{\mathrm{e}}$ em 1,0 (a); 0,65 (b); 0,57 (c); 0,55 (d) e 0,52 (e)

As curvas TG / DTA, (Fig. 33) mostram dois picos endotérmicos em $108^{\circ} \mathrm{C}$ e $470^{\circ} \mathrm{C}$ correspondentes, respectivamente, à perda de água e aos nitratos que não reagiram com a uréia ou com os seus produtos de decomposição. A perda de massa entre 300 e $500^{\circ} \mathrm{C}$ está relacionada aos produtos de decomposição na forma gasosa de $\mathrm{NO}_{x}, \mathrm{NH}_{3}$ e HNCO. Este comportamento é confirmado na Tab.10 pelo resultado de composição percentual dos elementos $\mathrm{C}, \mathrm{N}$ e $\mathrm{H}$ presentes nos produtos de decomposição dos pós, sem tratamento térmico e em pós calcinados a $700{ }^{\circ} \mathrm{C}$. 

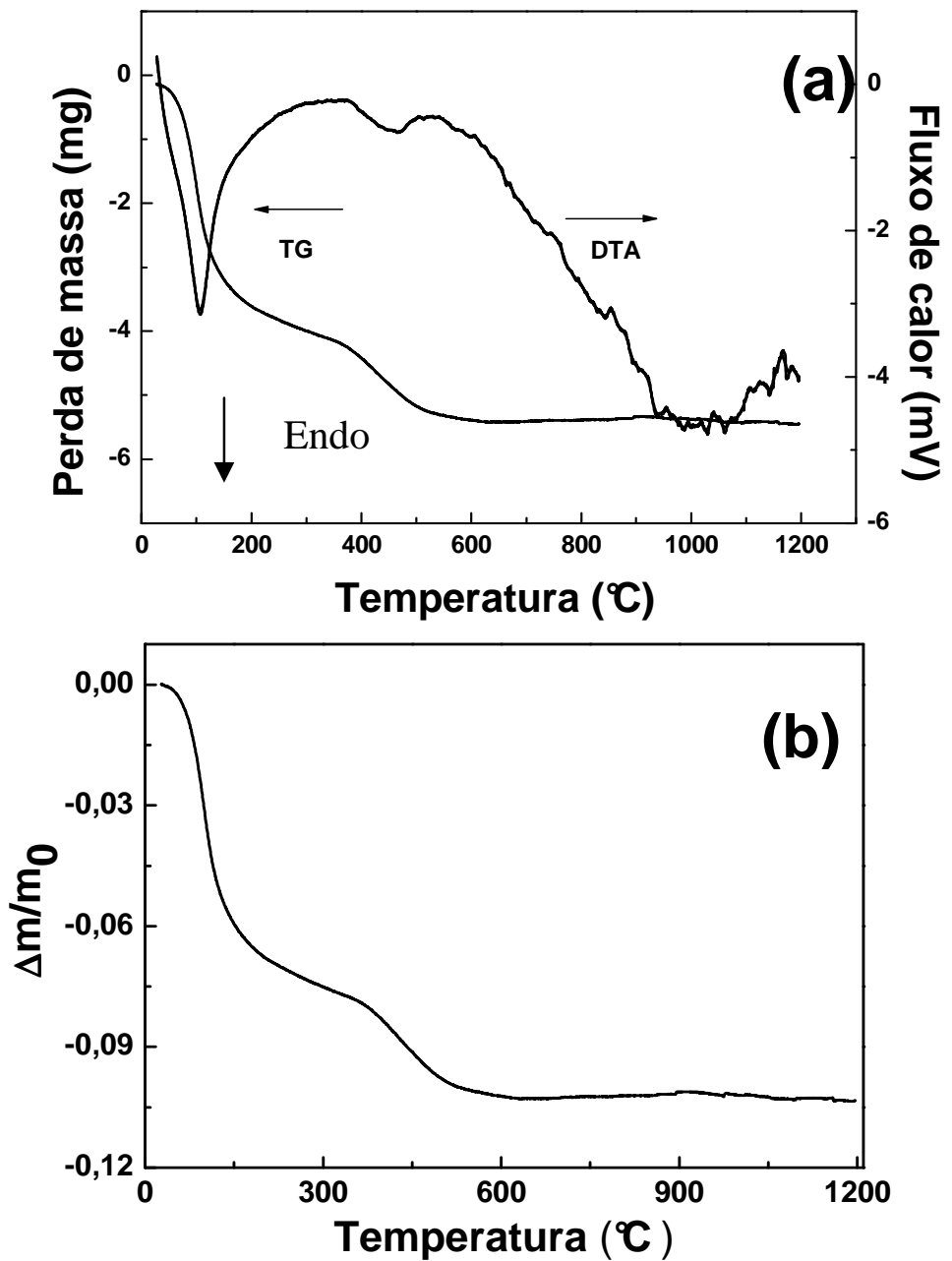

Figura 33 - Curvas TG/DTA obtidas e a $1^{\circ} \mathrm{C} \cdot \mathrm{min}^{-1}$ e sob atmosfera dinâmica de ar comprimido dos pós obtidos pelo método da combustão

Observa-se, pelos dados obtidos na Tab. 11, que com o aumento da temperatura de calcinação ocorre uma diminuição na quantidade de $\mathrm{C}$ presente nos pós.

Tabela 11. Análise elementar dos pós de NiO-YSZ sem tratamento térmico (CO 1), calcinados a 650 (CO 1-650) e 700 (CO 1 -700)

\begin{tabular}{cccc}
\hline Amostra & $\mathrm{C}(\%)$ & $\mathrm{H}(\%)$ & $\mathrm{N}(\%)$ \\
\hline \hline CO 1 & 0,19 & 0,88 & 0,37 \\
CO 1-650 & 0,15 & 0,33 & 0,03 \\
CO 1-700 & 0,07 & 0,04 & 0,06 \\
\hline \hline
\end{tabular}


Como pode ser observado nas micrografias, obtidas por microscopia de varredura (Fig. 34), a forma dos aglomerados apresenta uma significativa mudança em função da relação molar uréia/nitratos. Nas condições em que a uréia foi insuficiente a reação completa (Fig. 34.a) os pós apresentam-se na forma de aglomerados constituídos por nanopartículas, formando uma estrutura porosa devido à grande liberação de gases durante o processo de combustão. Na Fig. 34.b observa-se a formação de aglomerados de formas irregulares e de vários tamanhos, enquanto nas amostras com uma maior quantidade de combustível (Fig. 34.c, d, e) observa-se a formação de aglomerados com superfície rugosas e sinterizadas. Nestas amostras também pode ser observado os poros como conseqüência da liberação dos gases de combustão. Com o objetivo de verificar a possibilidade de eliminar a etapa de calcinação e avaliar a reatividade dos pós em função da temperatura de calcinação, os pós resultantes da síntese com valor estequiométrico de combustível foram avaliados em diversas temperaturas de calcinação e comparados com os pós resultantes da síntese com excesso de combustível. A avaliação foi realizada em função da microestrutura.

Os pós obtidos na síntese com a quantidade estequiométrica apresentam área de superfície específica de 120,2 $\mathrm{m}^{2} \cdot \mathrm{g}^{-1}$ (Tab.12) e tamanho médio de aglomerados de 0,63 $\mu \mathrm{m}$. Este valor elevado de área de superfície especifica está relacionado à grande quantidade de gases que são liberados que, além de quebrar os aglomerados primários, dissipa o calor de combustão e limita o aumento da temperatura, reduzindo a possibilidade de sinterização das partículas. Contudo, quando estes pós são submetidos à calcinação, a área de superfície específica sofre uma redução relativamente grande em função da sinterização parcial entre as partículas primárias produzidas durante a combustão e o tamanho médio de aglomerado aumenta, conforme as curvas indicadas na Fig. 35. Este processo é mais intenso com o aumento da temperatura de calcinação. 

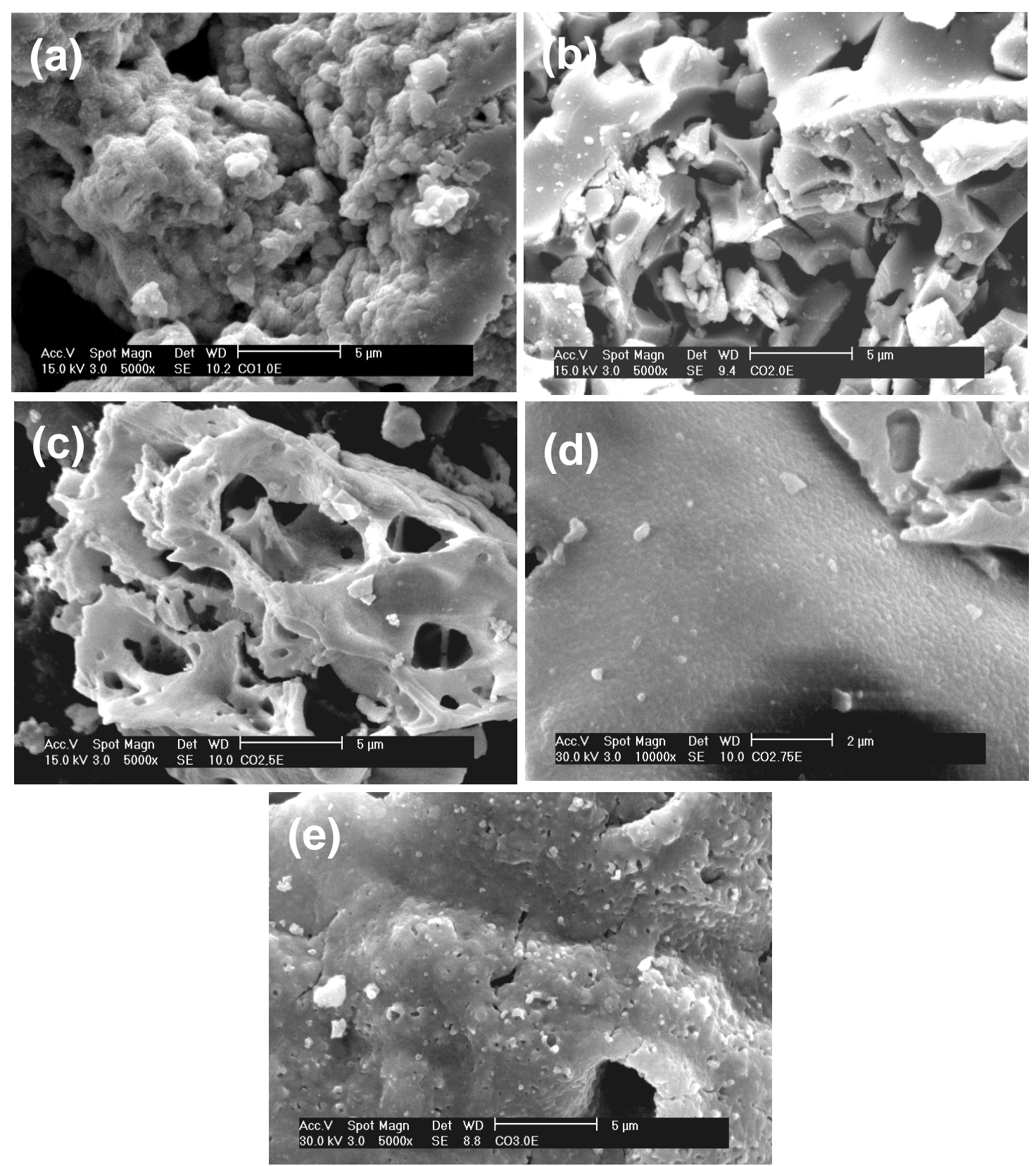

Figura 34 - Micrografias (MEV) dos pós obtidos por reação de combustão em função da relação molar uréia/nitratos, $\Phi_{e}$ em 1,0 (a); 0,65 (b); 0,57 (c); 0,55 (d) e 0,52 (e) 
Tabela 12 - Tamanho médio dos aglomerados, área de superfície especifica dos pós NiO-YSZ, sem calcinação e submetidos à calcinação entre 700 e $1000^{\circ} \mathrm{C}$.

\begin{tabular}{cccc}
\hline \hline Pós & $\begin{array}{c}\text { Temperatura de } \\
\text { calcinação }\left({ }^{\circ} \mathrm{C}\right)\end{array}$ & $\begin{array}{c}\text { Tamanho médio de } \\
\text { aglomerados }(\mathrm{nm})\end{array}$ & $\begin{array}{c}\text { Área de superfície } \\
\text { específica }\left(\mathrm{m}^{2} \cdot \mathrm{g}^{-1}\right)\end{array}$ \\
\hline CO 1 & --- & 630 & 120,2 \\
CO 1-700 & 700 & 1070 & 41,9 \\
CO 1-800 & 800 & 1250 & 18,5 \\
CO1-900 & 900 & 1340 & 9,1 \\
CO 1-1000 & 1000 & 1450 & 7,3 \\
\hline \hline
\end{tabular}

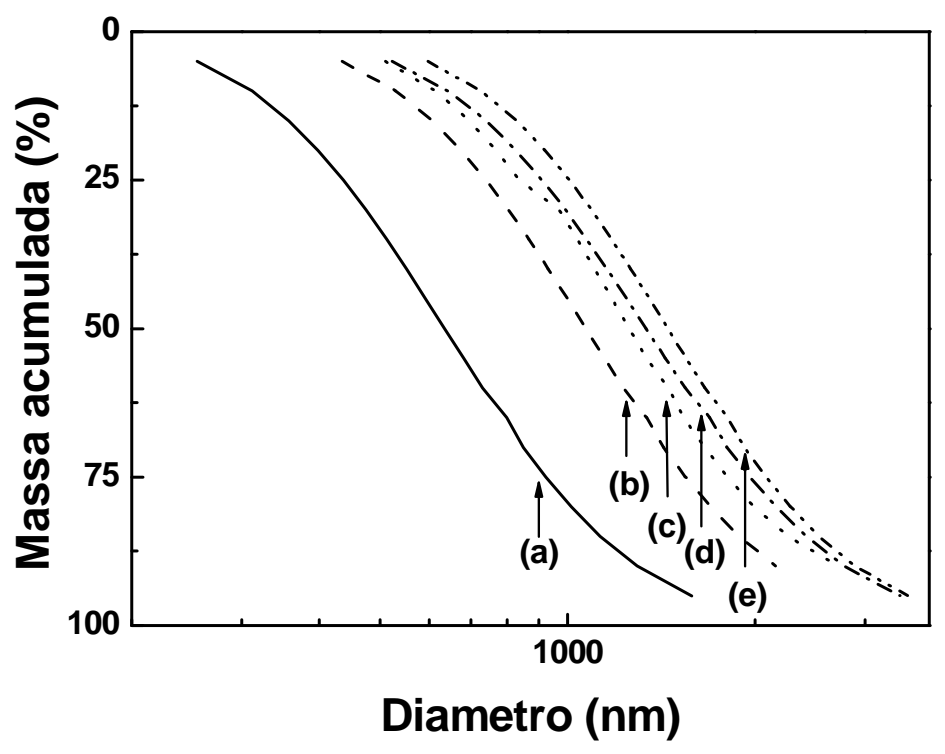

Figura 35 - Distribuição granulométrica dos pós de NiO-YSZ obtidos sob $\Phi=1$, sem tratamento térmico (a) e após calcinação: $700{ }^{\circ} \mathrm{C}$ (b), $800{ }^{\circ} \mathrm{C}$ (c), $900^{\circ} \mathrm{C}$ (d) e $10000^{\circ}$ ( e)

$\mathrm{Na}$ quantidade estequiométrica de combustível a baixa temperatura de reação e tempo de chama é insuficiente para completa cristalização das fases [76, 81]. No difratograma (a) da Fig. 36, que representa os pós obtidos na síntese e sem tratamento térmico, os picos de baixa intensidade referem-se ao $\mathrm{NiO}$. Por outro lado, sabe-se que temperaturas mais elevadas de calcinação induzem a uma maior energia de ativação, favorecendo cristalização, fato que é comprovado pelos difratogramas da Fig. 36.b a 36.e. 


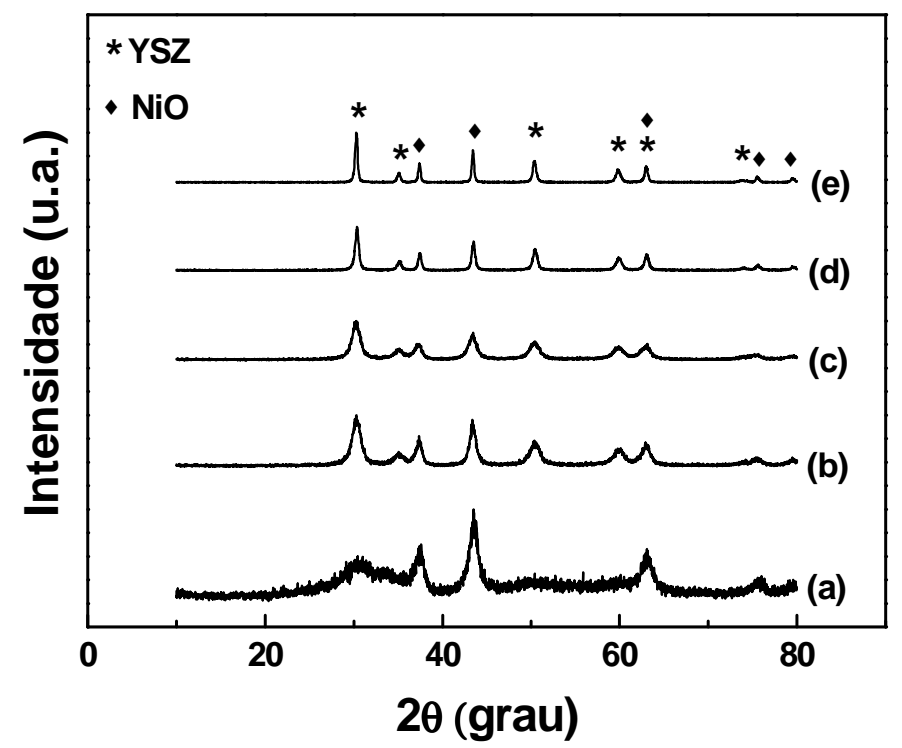

Figura 36 - Difratogramas de raios $X$ dos pós NiO-YSZ obtidos sob $\Phi=1$ sem tratamento térmico (a) e após calcinação: $700 \stackrel{\circ}{\circ}$ (b), $800 \stackrel{\circ}{\mathrm{C}}(\mathrm{c}), 900 \stackrel{\circ}{\mathrm{C}}$ (d) e $1000 \stackrel{\circ}{\circ} \mathrm{C}(\mathrm{e})$

Na Figura 37 é apresentada a distribuição granulométrica para efeito de comparação de pós obtidos com quantidade estequiométrica de combustível, pós calcinados a ${ }^{800} \mathrm{C}$ e com excesso de combustível e a respectiva distribuição dos pós submetido à moagem em moinho de bolas. Os efeitos destes diferentes tratamentos e moagem na morfologia dos pós são apresentados na Tab. 13.

Os pós obtidos em quantidade estequiométrica de combustível praticamente não sofreram nenhuma alteração após a moagem. Em relação aos pós submetidos à calcinação a $800^{\circ} \mathrm{C}$ e obtidos com excesso de combustível, estes apresentaram praticamente os mesmos valores de tamanho médio de aglomerado e área de superfície especifica, antes da etapa de moagem. $O$ efeito da moagem foi significativo apenas para os pós obtidos com excesso de combustível, sendo que o tamanho médio de aglomerado diminuiu praticamente pela metade e a área de superfície especifica teve apenas um leve aumento. 


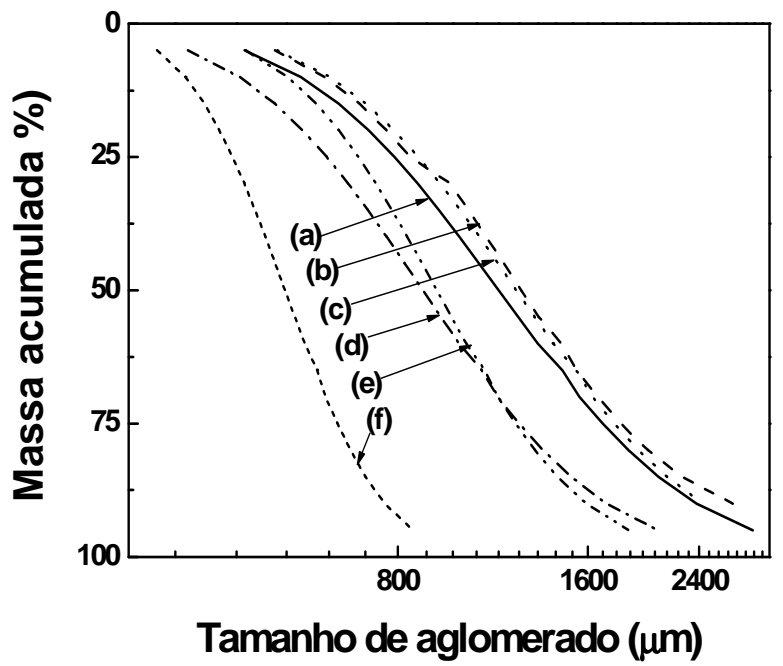

Figura 37- Distribuição granulométrica dos pós sem moagem: sem calcinação CO 1 (a), submetido à calcinação a $800^{\circ} \mathrm{C}$ CO 1-800 (b), obtidos com excesso de combustível $\mathrm{CO} 3,75$ (c) e submetidos à moagem: sem calcinação COM 1 (d), calcinados a $800^{\circ} \mathrm{C}$ COM $1-800$ (e) e com excesso de combustível COM 3,75 (f)

Tabela 13 - Tamanho médio dos aglomerados, área de superfície especifica dos pós NiO-YSZ sem moagem: (CO 1), (CO 1-800) e (CO 3,75) e submetidos à moagem: (COM 1), (COM 1-800) e $\quad(C O M \quad 3,75)$

\begin{tabular}{ccc}
\hline \hline Pós & $\begin{array}{c}\text { Tamanho de } \\
\text { aglomerados }\end{array}$ & $\begin{array}{c}\text { Área de } \\
\text { superfície } \\
\text { específica } \\
(\mu \mathrm{m})\end{array}$ \\
\hline \hline CO 1 & $\left.\mathrm{m}^{-1}\right)$ \\
COM 1 & 1,16 & 120,2 \\
CO 1-800 & 1,07 & 124 \\
COM 1-800 & 0,25 & 18,5 \\
CO 3,75 & 1,23 & 19,41 \\
COM 3,75 & 0,53 & 19,78 \\
\hline
\end{tabular}

Como pode ser observado nas micrografias, obtidas por microscopia de varredura, (Fig. 38), a forma dos aglomerados obtidos apresenta uma significativa mudança em função da temperatura de calcinação. Nas condições 
em que a uréia foi insuficiente para uma reação completa [Fig. 38 (a)] os pós obtidos apresentam-se na forma de aglomerados constituídos por nanopartículas, formando uma estrutura porosa devido à grande liberação de gases durante o processo de combustão. Na Fig. 38 (b) e (c) observa se a formação de aglomerados com superfícies rugosas e sinterizadas. Nestas amostras também pode ser observado os poros como conseqüência da liberação dos gases de combustão.
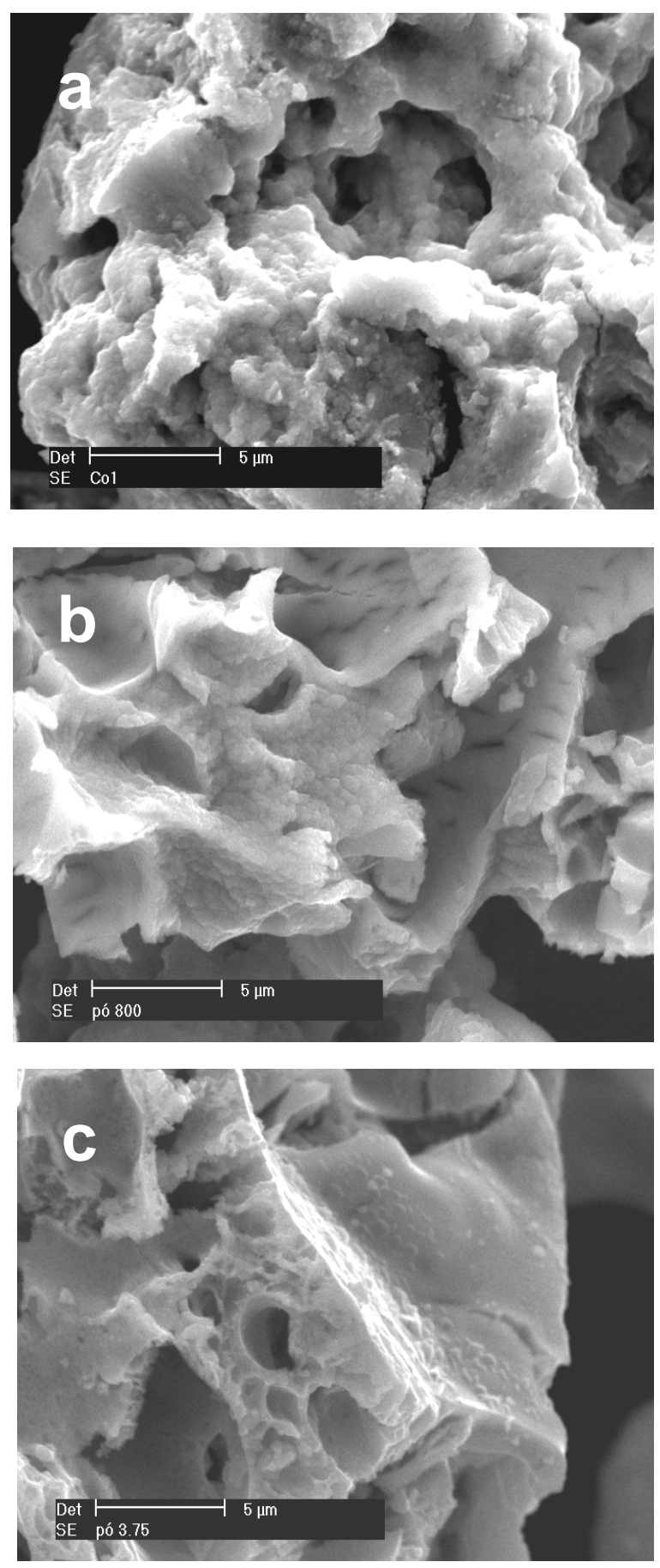

Figura 38 - Micrografias MEV dos pós: (CO 1) (a), $800 \stackrel{\circ}{\circ}$ (CO 1-800) (b) e $(\mathrm{CO} 3,75)(\mathrm{c})$ 
$\mathrm{Na}$ Fig. 39 são apresentadas as micrografias dos pós que foram submetidos à moagem, onde se observa o menor tamanho dos aglomerados em relação aos pós não moídos.
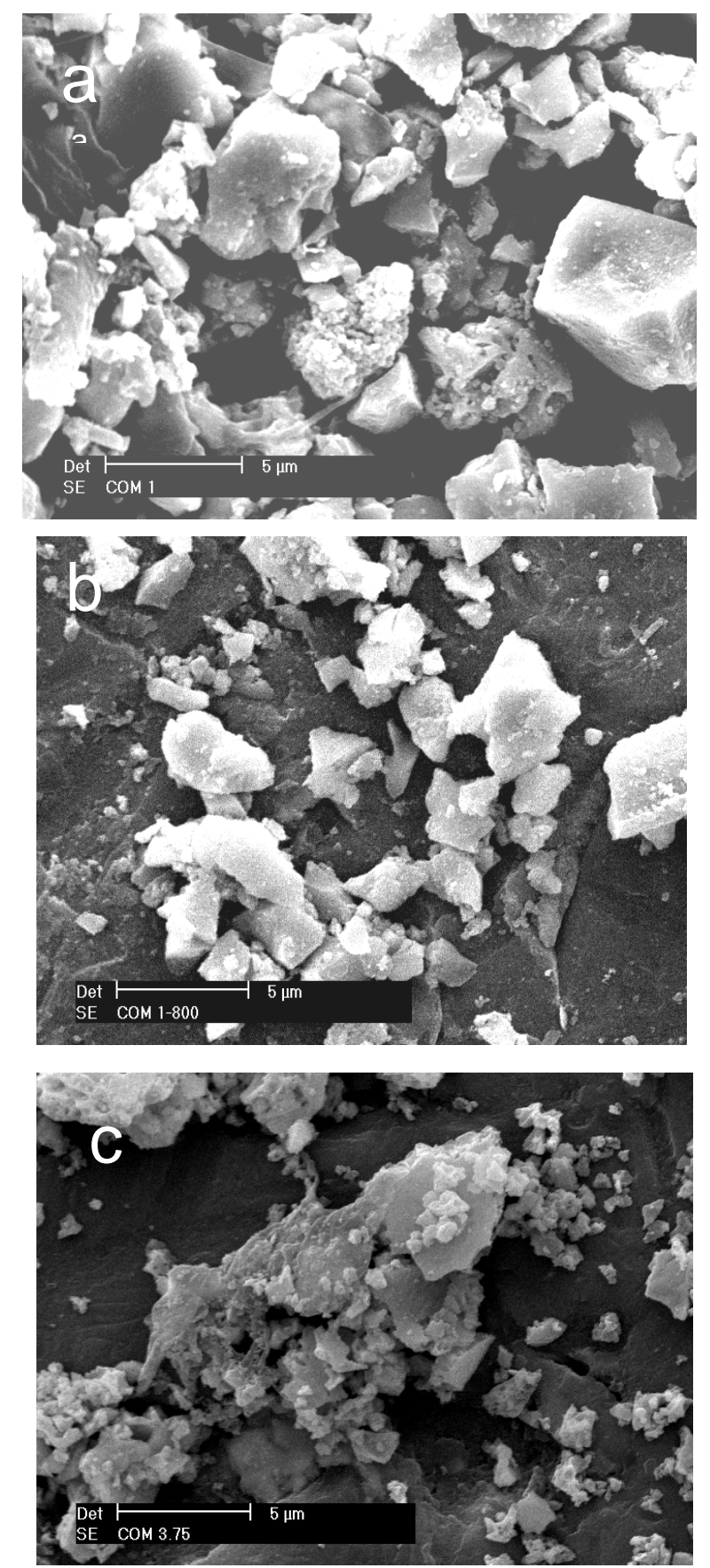

Figura 39 - Micrografias MEV dos pós submetidos à moagem das amostras: COM 1 (a), COM 1-800 calcinada a $800 \stackrel{\circ}{\circ}$ (b) e $\operatorname{COM~3,75~(c)~}$ 
Uma comparação da retração relativa, medida em dilatômetro, entre as amostras obtidas a partir de pós sem moagem (amostras $\mathrm{CO}$ ) e amostras com pós precursores moídos (amostras COM), é apresentada na Fig, 40.a e Fig. 40.b e Tab. 13. Pelas curvas de retração apresentadas, pode-se concluir que amostras submetidas à moagem (COM 1, COM 1-800 e COM 3,75) são as que apresentaram uma pequena melhora na sinterabilidade. Na amostra COM 1 a sinterização começa em 350 ㅇ C e atinge uma retração de $14,0 \%$ após 173 minutos $(1396 \stackrel{\circ}{\circ})$. Outra informação que pode ser observada em relação às amostras obtidas após a moagem é que o efeito da moagem foi pouco significativo em relação à retração linear. $\mathrm{Na}$ faixa de temperatura estudada a amostra com excesso de combustível $(\mathrm{CO} 3,75)$ foi a que apresentou maior retração linear e a temperatura final adotada foi insuficiente para densificação total da amostra.
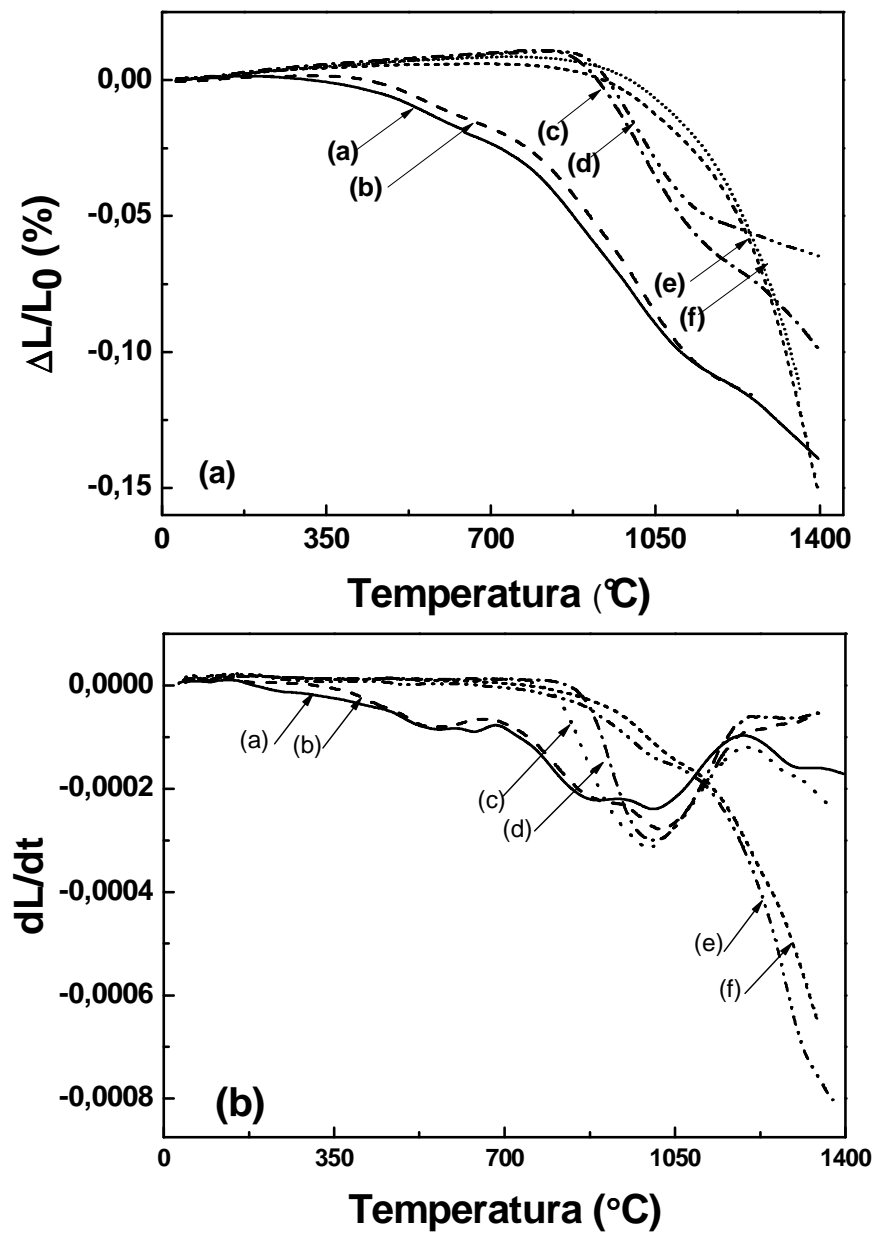

Figura 40 - Curvas de retração linear (a), obtidas a $10^{\circ} \mathrm{C} / \mathrm{min}$ em fluxo de ar atmosférico para corpo cerâmico: COM1 (a), CO 1 (b), $\quad$ COM 1-800 (c), CO 1-800 (d), COM 3,75 (e) e CO3,75 (f) e as respectivas derivadas das curvas de retração linear (b) 
No caso da amostra CO 1-800 e COM 1-800 a retração passa a ser significativa a partir do momento em que é atingida a temperatura de précalcinação dos pós de partida.

As amostras obtidas de pós calcinados a $800^{\circ} \mathrm{C}$ e submetidos à moagem (COM 1-800) apresentam uma retração linear total de 10\%, cerca de $4,0 \%$ maior que as amostras obtidas de pós sem moagem (CO 1-800), sendo o intervalo entre 730 e $1000 \stackrel{\circ}{C}$ a região onde o processo de retração é mais intenso. Nas amostras CO 3,75 e COM 3,75 a retração linear das amostras começa partir de $800^{\circ} \mathrm{C}$ temperatura esta que corresponde à temperatura de ignição que ocorre durante a síntese. A retração torna-se mais intensa para temperaturas acima de $1200^{\circ} \mathrm{C}$. Para amostra que não foi submetida a nenhum tratamento térmico ( $\mathrm{CO}$ 1) a retração foi maior quando comparada com a amostra que foi submetida à calcinação (CO 1-800). Esta amostra apresenta uma curva de sinterização com várias etapas de retração, sendo que para baixa temperatura $\left(<500^{\circ} \mathrm{C}\right)$ provavelmente esteja r elacionado à eliminação dos resíduos da reação de combustão. As demais etapas de retração correspondem ao processo de sinterização. Parâmetros de retração linear das diferentes amostras são apresentados na Tab.14.

Tabela 14 - Máxima taxa de retração e retração linear total para as amostras obtidas a partir de pós NiO-YSZ

\begin{tabular}{|c|c|c|c|c|}
\hline Amostra & $\begin{array}{l}\text { Temperatura } \\
\text { de calcinação } \\
\left({ }^{\circ} \mathrm{C}\right)\end{array}$ & Moagem & $\begin{array}{c}\text { Temperatura no ponto } \\
\text { de máximo de } \\
\text { retração }\left({ }^{\circ} \mathrm{C}\right)\end{array}$ & $\begin{array}{l}\text { Retração } \\
\text { linear (\%) }\end{array}$ \\
\hline $\mathrm{CO} 1$ & $\overline{---}$ & Sem & 1019,52 & 12,4 \\
\hline COM 1 & --- & Com & 1005,80 & 14,0 \\
\hline CO 1-800 & 800 & Sem & 1007,75 & 6,5 \\
\hline COM 1-800 & 800 & Com & 1000,00 & 10.0 \\
\hline CO 3,75 & --- & Sem & --- & 14,4 \\
\hline COM 3,75 & --- & Com & --- & 15,2 \\
\hline
\end{tabular}


$\mathrm{Na}$ Tab. 15 são apresentados os resultados da densificação das amostras analisadas no dilatômetro. Observa-se que as amostras submetidas à moagem foram as que apresentaram maior densidades, quando comparadas

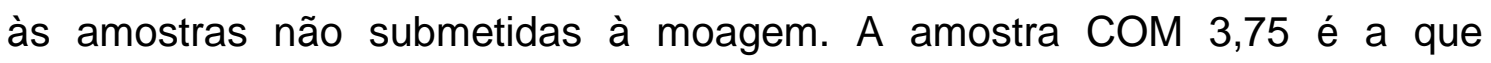
apresentou a maior densidade relativa e a amostra obtida sem excesso de combustível (CO 1) a menor densidade relativa.

Tabela 15 - Valores de densidades e porosidade para as amostras obtidas a partir de pós NiO-YSZ sem moagem (CO), com moagem (COM), sem tratamento térmico (CO 1) e calcinados (CO 1-800, COM 1-800) a $800{ }^{\circ} \mathrm{C}$ e com excesso de combustível (CO 3,75, $\mathrm{COM} 3,75)$

\begin{tabular}{ccccccc}
\hline Amostra & $\mathrm{CO}$ & $\mathrm{COM}$ & $\mathrm{CO}$ & $\mathrm{COM}$ & $\mathrm{CO}$ & $\mathrm{COM}$ \\
& 1 & 1 & $1-800$ & $1-800$ & 3,75 & 3,75 \\
\hline Densidade Hidrostatica & 3,97 & 4,70 & 3,75 & 4,69 & 4,87 & 6,15 \\
Porosidade (\%) & 31,46 & 23,16 & 35,37 & 23,46 & 18,22 & 0,48 \\
Densidade Aparente & 5,8 & 6,11 & 5,81 & 6,13 & 5,85 & 6,18 \\
Densidade Relativa & 60,49 & 71,83 & 52,79 & 72,14 & 67,96 & 91,33 \\
\hline \hline
\end{tabular}

As superfícies polidas da secção transversal das amostras conformadas por prensagem uniaxial e sinterizadas a $1350{ }^{\circ} \mathrm{C}$ por uma hora, apresentadas na Fig. 41, evidenciam a alta porosidade das cerâmicas. Este fenômeno esta relacionado com a mudança no tamanho de partículas e na energia de ativação após a calcinação dos pós. A temperatura de calcinação dos pós não tem influência no tamanho dos poros, a maior porosidade das amostras está relacionada com a quantidade de poros nas amostras e não com o tamanho dos poros. Nas amostras em que os pós não foram submetido à calcinação e calcinados a $800{ }^{\circ} \mathrm{C}$, o efeito da moagem dos pós precursores não é significativo no tamanho de grãos das fases após a sinterização do corpo cerâmico. Observa-se que a moagem favorece a formação de estrutura mais densa e, sem a presença de grandes poros, a porosidade final das cerâmicas é praticamente a mesma independente da temperatura de calcinação dos pós. 

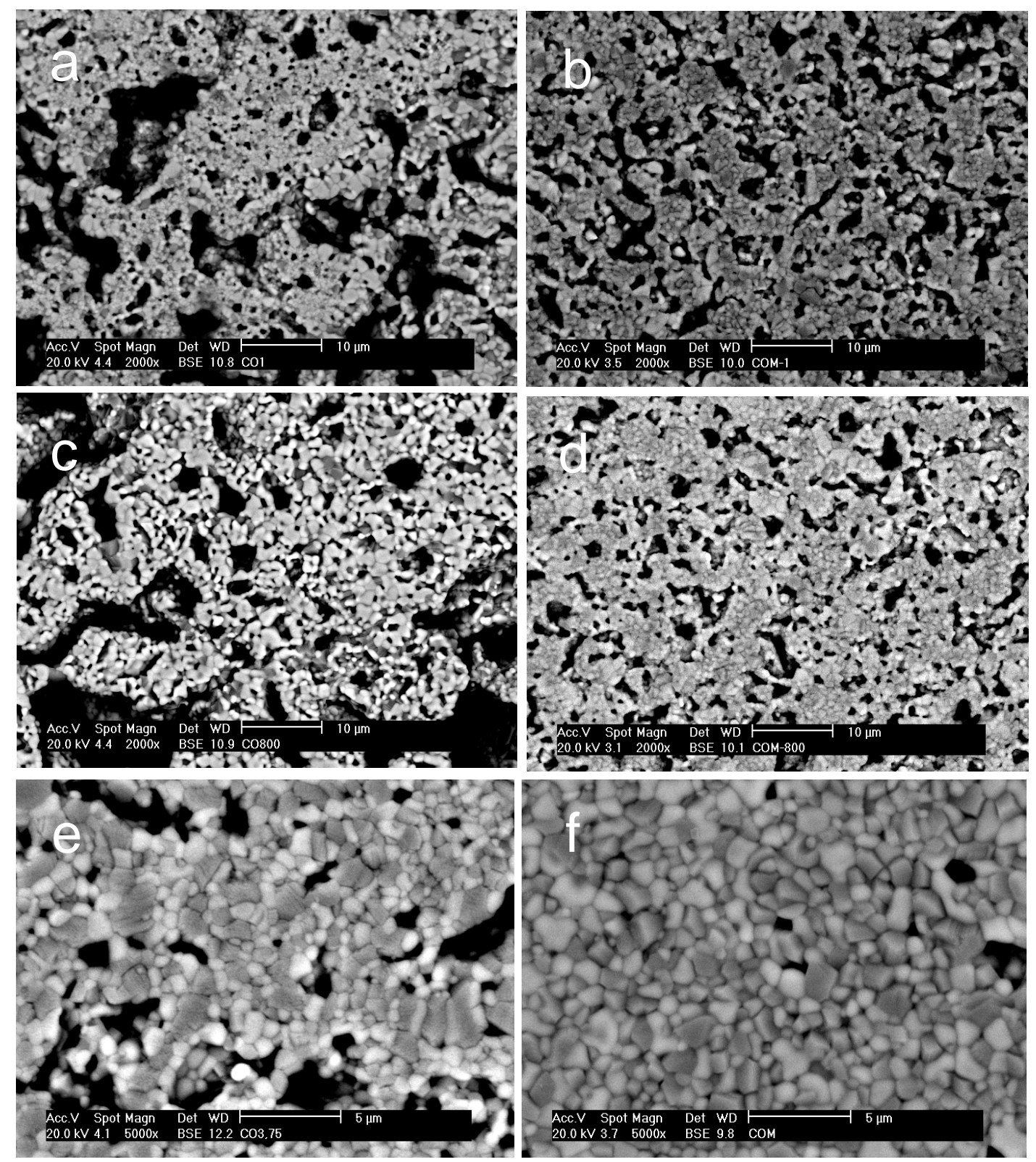

Figura 41 - Micrografias (MEV) das superfícies polidas e tratadas termicamente relativas às amostras cerâmicas NiO-YSZ obtidas por combustão em função da temperatura de calcinação dos pós: $\mathrm{CO} 1$ (a), $\quad$ CO 1-800 ํㅡ (c), CO 3,75 (e) e em função da moagem: $\operatorname{COM} 1$ (b), $\operatorname{COM} 800^{\circ} \mathrm{C}$ (d) e $\operatorname{COM} 3,75(f)$

Outro estudo realizado foi avaliar a influência da temperatura de calcinação acima de $800{ }^{\circ} \mathrm{C}$ na densificação das amostras. Uma comparação da retração linear entre as amostras CO1 (sem calcinação) e amostras preparadas a partir de pós calcinados a 800 e $1000^{\circ} \mathrm{C}$ indicam que o aumento 
da temperatura de calcinação dos pós inibe a retração (Tab. 16 e Fig. 42). Na curva dilatométrica da amostra CO1 observa-se várias etapas de retração, sendo que em temperatura próxima a $500^{\circ} \mathrm{C}$ a retração é devido à eliminação dos resíduos da reação de combustão. As demais etapas de retração correspondem ao processo de sinterização.

No caso da amostra CO1-800 a retração passa a ser significativa a partir do momento em que é ultrapassada a temperatura de calcinação dos pós de partida. O baixo valor de retração da amostra CO1-1000 está relacionado à alta temperatura de calcinação do material. Nesta temperatura o material já pode ser considerado como um material pré-sinterizado.
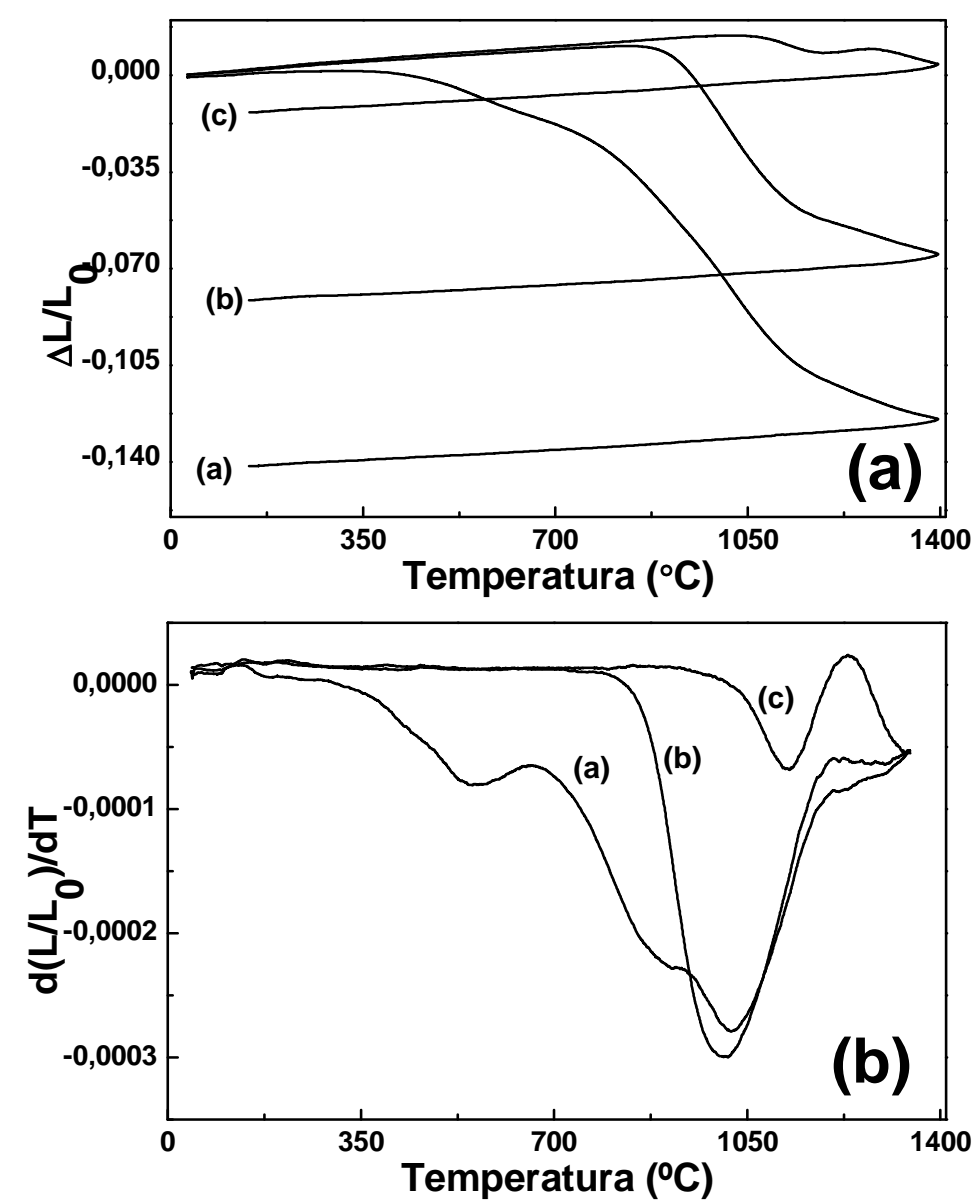

Figura 42- Curvas de retração linear (a), e de taxa de retração linear (b), obtidas a $10^{\circ} \mathrm{C} / \mathrm{min}$ em fluxo de ar atmosférico para os corpos cerâmicos: CO1 (a), CO1-800 (b) e CO1-1000 (c) 
Tabela 16 - Máxima taxa de retração e retração linear total para as amostras obtidas a partir de pós $\mathrm{NiO}-\mathrm{YSZ}$ sem tratamento térmico e calcinados a $800 \stackrel{\circ}{ } \mathrm{C}$ (CO 1-800)e $1000^{\circ} \mathrm{C}$ (CO 1-1000).

\begin{tabular}{ccc}
\hline \hline Amostra & $\begin{array}{c}\text { Temperatura no ponto de } \\
\text { máximo de retração }\left({ }^{\circ} \mathrm{C}\right)\end{array}$ & Retração linear total $(\%)$ \\
\hline \hline CO 1 & 1020 & 14,2 \\
CO $1-800$ & 1008 & 8,2 \\
CO $1-1000$ & 1124 & 1,34 \\
\hline \hline
\end{tabular}

Na Tab. 17 estão listadas as principais características físicas dos corpos de provas e conclui-se que as porosidades obtidas são adequadas para uso das cerâmicas como anodo, porém tanto os poros como a distribuição das fases não são homogêneas. A temperatura de calcinação tem influência tanto na densidade aparente quanto na relativa e, quanto maior a temperatura de calcinação, menor os valores de densidade.

Tabela 17 - Valores de densidades para amostra não calcinada (CO 1) e calcinadas a $800{ }^{\circ} \mathrm{C}(\mathrm{CO} 1-800)$ e $1000{ }^{\circ}$ (CO 1-100 0).

\begin{tabular}{llll}
\hline Amostra & CO 1 & CO 1-800 & CO 1-1000 \\
\hline Densidade Hidrostatica & 3,97 & 3,75 & 3,60 \\
Porosidade (\%) & 31,46 & 35,37 & 37,11 \\
Densidade Aparente & 5,8 & 5,81 & 5,73 \\
Densidade Relativa (\%) & 61,46 & 58,05 & 55,73 \\
\hline
\end{tabular}

As superfícies polidas e atacadas termicamente da secção transversal das amostras conformadas por prensagem uniaxial e sinterizadas a $1350 \stackrel{\circ}{ } \mathrm{C}$ por uma hora, apresentadas na Fig. 43, evidenciam a alta porosidade das cerâmicas. Este fenômeno está relacionado com a mudança no tamanho de partículas e na energia de ativação, após a calcinação dos pós.

$\mathrm{Na}$ amostra $\mathrm{CO} 1$ (Fig. 43.a) a fase $\mathrm{NiO}$ apresenta uma maior aglomeração e maior tamanho de grãos, em relação à fase de zircônia 
estabilizada e distribuição não homogênea das fases. Na amostra CO1-800 (Fig.43.b) observa-se que os tamanhos de grãos de ambas as fases são praticamente de mesma dimensão. Por sua vez, na amostra C 1-1000 (Fig. 43.c) o tamanho dos grãos não apresenta uma uniformidade assim como a distribuição das fases.
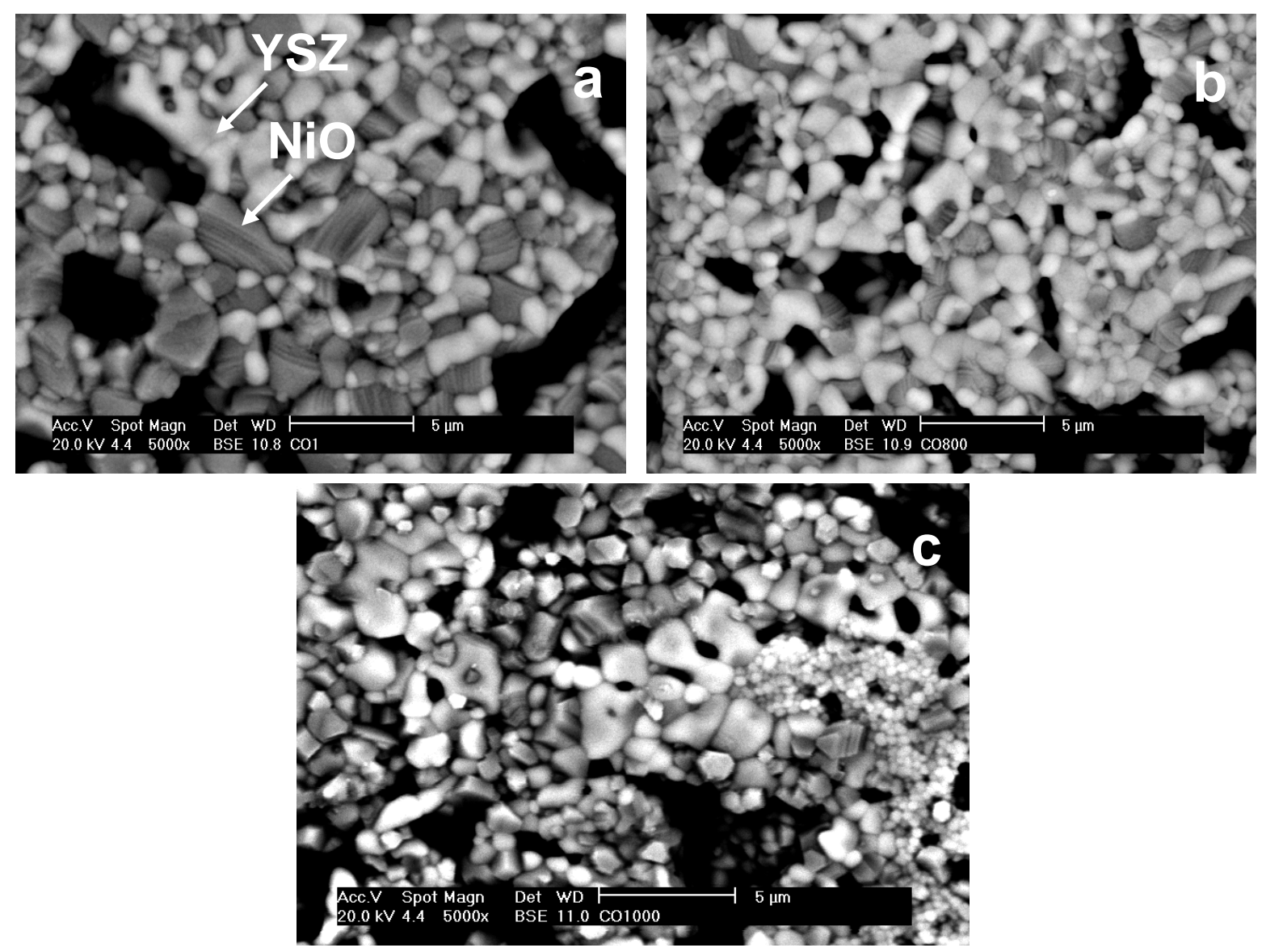

Figura 43 - Micrografias (MEV) das superfícies polidas e tratadas termicamente relativas às amostras cerâmicas NiO-YSZ, em função da temperatura de calcinação dos pós: sem calcinação (CO 1) (a), calcinado a $800{ }^{\circ} \mathrm{C}(\mathrm{CO} 1-800)$ (b) e calcinado a 1000 C (CO 1-1000) (c)

Na Fig. 44 são apresentadas as micrografias das amostras que foram submetidas à atmosfera redutora de uma mistura gasosa de $4 \% \mathrm{H}_{2}$ em balanço com Ar. A mudança na porosidade das amostras é conseqüência da formação de uma camada fina de poros ao redor dos grãos de $\mathrm{Ni}$, visto que a redução não causa uma mudança visível no tamanho dos poros. As amostras 
submetidas à moagem (COMR 1; COMR 1-800 e COMR 3,75) apresentam poros menores e com distribuição mais homogênea.
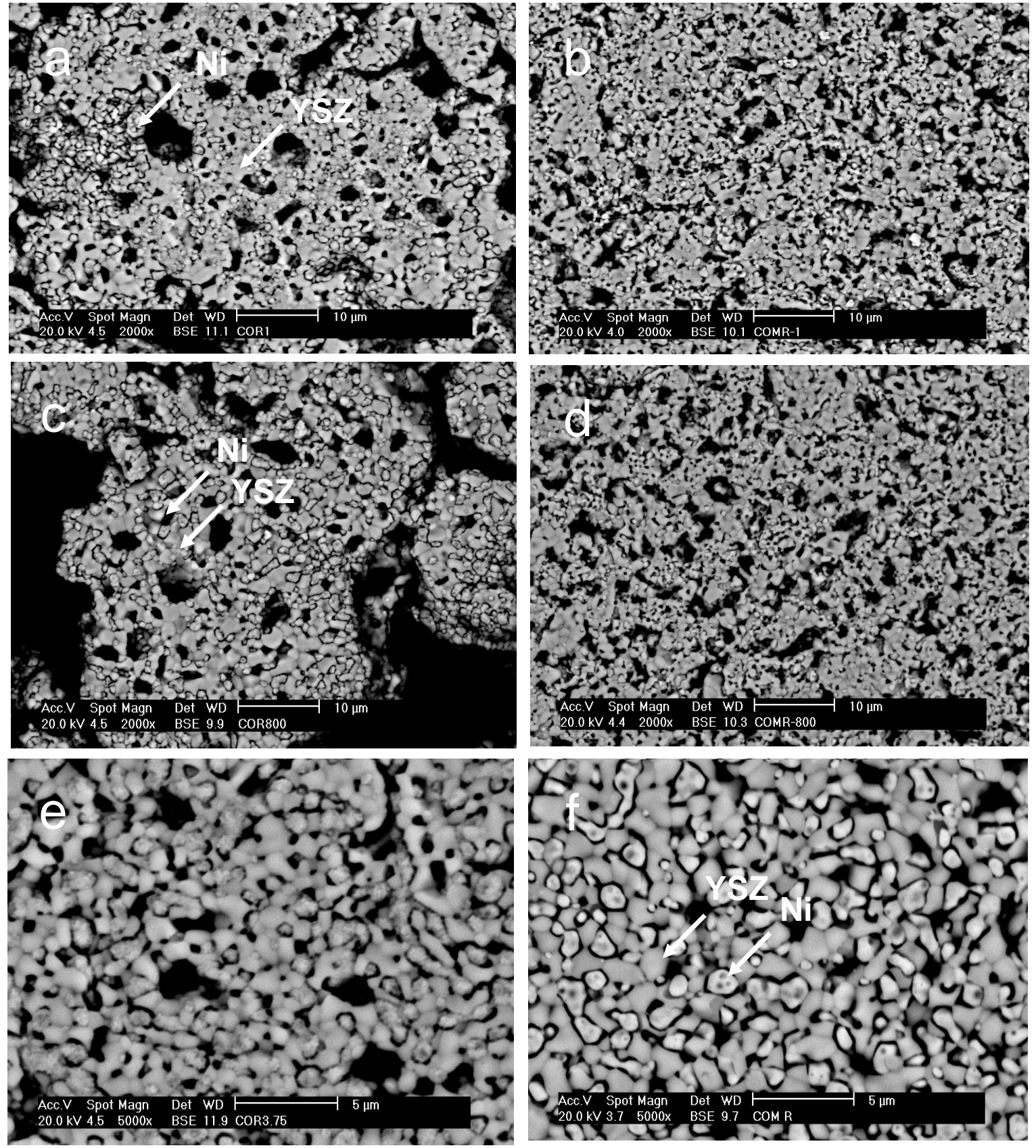

Figura 44 - Micrografias (MEV) das superfícies polidas e tratadas termicamente relativas às amostras cerâmicas Ni-YSZ submetidas à redução em atmosfera redutora de $4 \% \mathrm{H}_{2}-96 \%$ Ar das amostras : COR 1 (a), COMR 1 (b), COR 1-800 (c), COMR 1-800 (d), CO 3,75 (e) e COMR 3.75 (f) 
$\mathrm{Na}$ Tab.18 são apresentadas os valores de densidade hidrostática das amostras obtidas a partir de pós que foram submetidos à moagem e amostra sem a etapa de moagem. Em todas as condições estudadas, o valor da densidade aumenta com a etapa de moagem. Outra conclusão é que os melhores resultados foram obtidos para amostras com excesso de combustível $(\mathrm{CO} 3,75)$ confirmando que a etapa de calcinação pode ser eliminada por este método.

Tabela 18 - Densidades das amostras após a redução do óxido de níquel para níquel metálico

\begin{tabular}{ccccccc}
\hline \hline Amostra & CO & COM & CO & COM & CO & COM \\
& 1 & 1 & $1-800$ & $1-800$ & 3,75 & 3,75 \\
\hline Densidade Hidrostatica & 3,55 & 4,37 & 3,48 & 4,32 & 4,41 & 5,68 \\
Porosidade (\%) & 47,92 & 37,14 & 49,34 & 37,18 & 37,00 & 13,10 \\
Densidade Aparente & 6,82 & 6,95 & 6,88 & 6,88 & 7,00 & 6,53 \\
\hline \hline
\end{tabular}

\section{V.4 - Estudo comparativo de processamento dos pós obtidos a partir da otimização dos métodos de síntese adotados}

Com a definição dos parâmetros otimizados de síntese para os três métodos, o estudo seguinte envolveu a definição das condições de processamento cerâmico dos pós obtidos. Para efeito de comparação foram adotados os mesmos parâmetros de moagem de alta energia e prensagem uniaxial, para os pós obtidos pelas três rotas: a composição teórica em massa adotada foi de $56 \mathrm{NiO}$ : $44 \mathrm{YSZ}$ sendo $8,5 \%$ a concentração de $\mathrm{Y}_{2} \mathrm{O}_{3}$ em relação a zircônia. No caso especifico dos pós obtidos por combustão foi adotada a relação de $150 \%$ de excesso de combustível em relação aos nitratos em função da temperatura de chama ser suficiente para completa cristalização das fases NiO e YSZ. A Tab.19 apresenta as principais características físicas dos pós. 
Tabela 19 - Características físicas dos pós de $56 \%$ NiO:YSZ obtidos pelas três rotas de síntese e moagem em moinho de alta energia por 6 horas

\begin{tabular}{ccccc}
\hline $\begin{array}{c}\text { Método de } \\
\text { síntese }\end{array}$ & $\begin{array}{c}\text { Tamanho médio } \\
\text { de aglomerado } \\
(\mu \mathrm{m})\end{array}$ & $\begin{array}{c}\text { Área de } \\
\text { superfície } \\
\text { específica } \\
\left(\mathrm{m}^{2} \mathrm{~g}^{-1}\right)\end{array}$ & $\begin{array}{c}\text { Densidade } \\
\text { Teórica } \\
\left(\mathrm{g} \cdot \mathrm{cm}^{-3}\right)\end{array}$ & $\begin{array}{c}\text { Tamanho } \\
\text { de partícula } \\
(\mathrm{nm})\end{array}$ \\
\hline Coprecipitação & 14,47 & 37,27 & 6,44 & 15 \\
Combustão & 0,36 & 71,19 & 6,44 & 10 \\
Mistura de pós & 15,25 & 62,43 & 6,44 & 10 \\
\hline
\end{tabular}

Como pode ser observado por microscopia eletrônica de varredura (MEV), Fig.45.a, Fig.45.b e Fig.45.c, os aglomerados são formados por partículas submicrométricas. Nas micrografias obtidas por microscopia eletrônica de transmissão (MET), Fig.46.d, Fig. 46.e e Fig.46.f, observa-se que as partículas apresentam formato arredondado e com dimensões aproximadamente de 15, 10 e $10 \mathrm{~nm}$ para pós obtidos por coprecipitação, combustão e mistura de pós, respectivamente. 

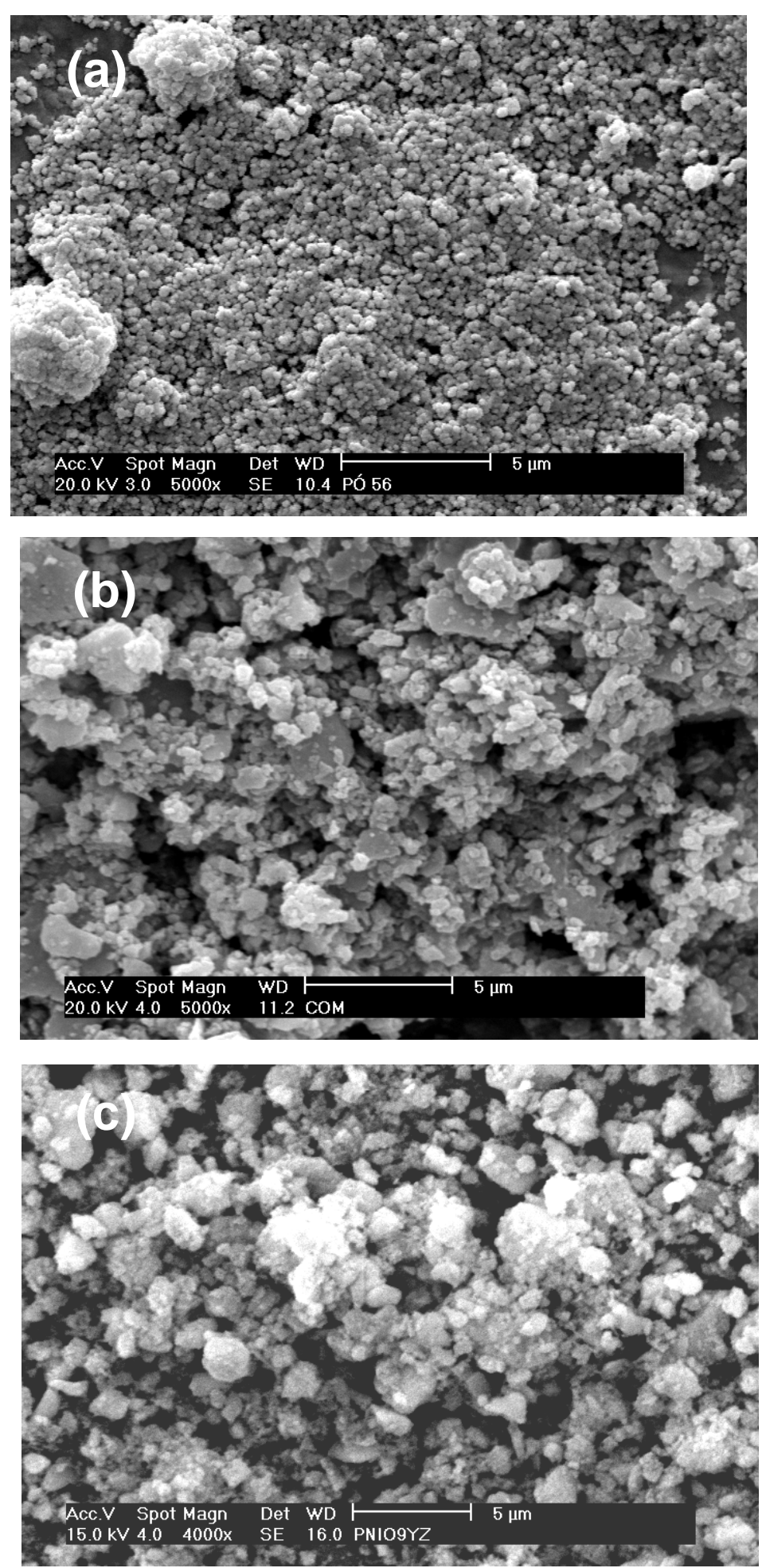

Figura 45 - Micrografias obtidas por MEV (a,b,c) dos pós com $56 \%$ em massa de $\mathrm{NiO}$ em 8,5YSZ obtido por coprecipitação (a), combustão (b) e mistura de pós (c). 

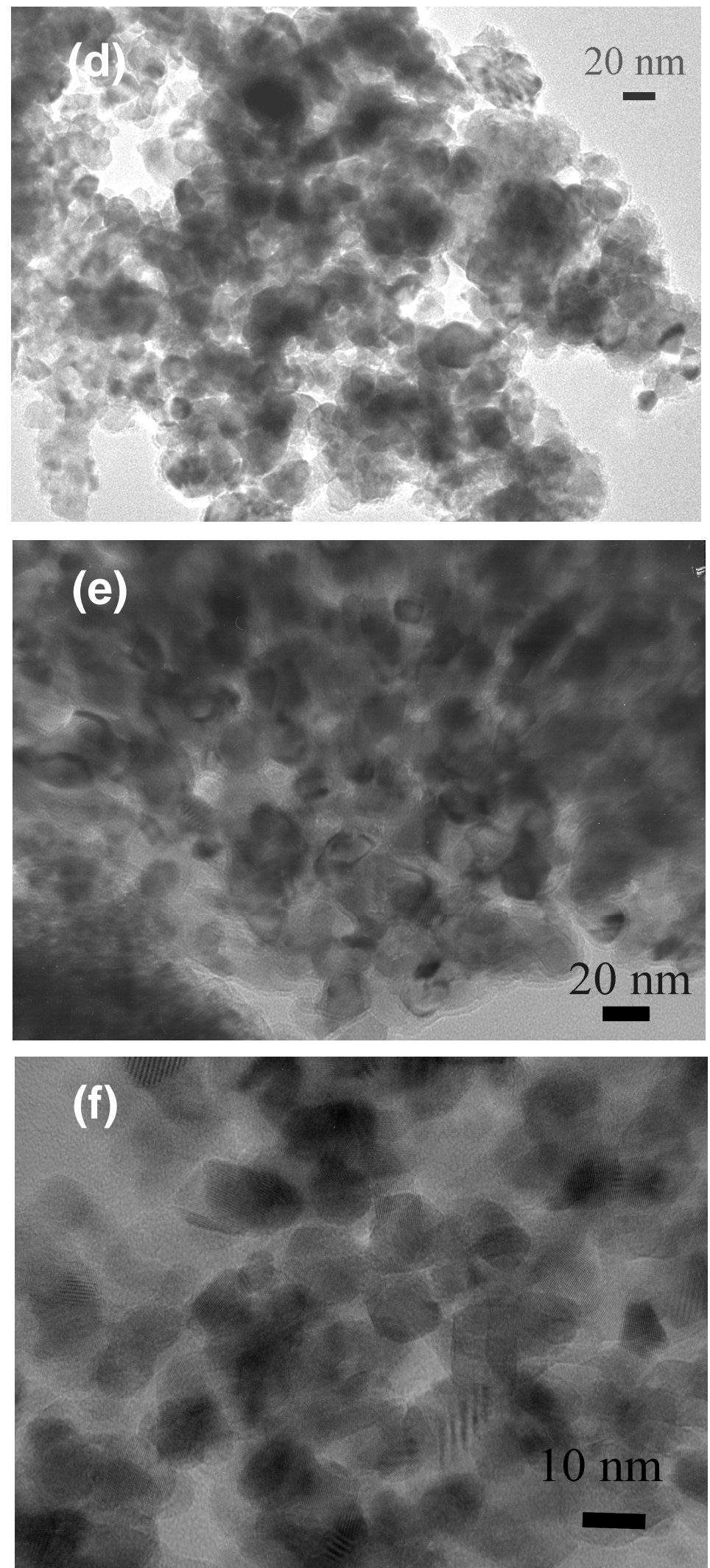

Figura 46 - Micrografias obtidas por MET (d,e,f) dos pós com 56 \% em massa de NiO em 8,5YSZ obtido por coprecipitação (d), combustão (e) e mistura de pós (f). 


\section{V.4.1- Estudo de sinterização}

O comportamento de sinterização foi estudado sob condição não isotérmica, com aquecimento a taxa constante entre 5 e $20^{\circ} \mathrm{C} \cdot \mathrm{min}^{-1}$ e atmosfera dinâmica de ar sintético.

Nas Figuras 47.a, 47.c e 47.e são apresentadas as curvas de retração linear e respectivas taxas de retração em função da temperatura para pós de NiO-YSZ obtidos pela técnica de coprecipitação (CP), combustão (CO) e mistura de pós (MP), sob diferentes taxas de aquecimento, em atmosfera dinâmica de ar sintético. Para amostras obtidas pelo método $\mathrm{CP}$, pode-se observar que, com o aumento da taxa de aquecimento, o início da retração e a máxima taxa de retração (Figuras 47.b, 47.d e 47.f) é deslocado para temperaturas um pouco mais elevadas. A maior taxa de retração linear ocorre a $1279 \stackrel{\circ}{\circ}$ para uma taxa de aquecimento constante de $5 \stackrel{\circ}{\circ} \mathrm{C} \cdot \mathrm{min}^{-1}, 1303 \stackrel{\circ}{\circ} \mathrm{C}$ para $10 \stackrel{\circ}{\circ}$. $\mathrm{min}^{-1}, 1322 \stackrel{\circ}{\circ} \mathrm{C}$ para uma taxa de $15 \stackrel{\circ}{\circ} \mathrm{C} \cdot \mathrm{min}^{-1}$ e $1332 \stackrel{\circ}{\circ} \mathrm{C}$ para $20 \stackrel{\circ}{\circ} \mathrm{C} \cdot \mathrm{min}^{-1}$. Estas temperaturas determinam a transição entre o domínio do mecanismo de densificação e de crescimento de grãos.

Os resultados relacionados aos outros dois métodos de síntese foram obtidos na mesma condição de ensaio das amostras CP e são apresentados na Tab.20.

Tabela 20 - Temperatura na máxima taxa de retração e retração linear total das amostras de 56\% NiO:YSZ obtidas pelas técnicas de coprecipitação, combustão e mistura de pós submetidas a diferente taxa de aquecimento (5, 10, 15 e $20{ }^{\circ} \mathrm{C} \cdot \mathrm{min}^{-1}$ ). Dados obtidos para amostras CO e MP (combustão e mistura de pós), na mesma condição de ensaio das amostras CP.

\begin{tabular}{cccccc}
\hline \hline Parâmetro avaliado & Método de & \multicolumn{4}{c}{ Taxa de aquecimento $\left({ }^{\circ} \mathrm{C} . \mathrm{min}^{-1}\right)$} \\
\cline { 3 - 6 } & síntese & 5 & 10 & 15 & 20 \\
\hline Temperatura de máxima taxa & $\mathrm{CP}$ & 1279 & 1303 & 1322 & 1332 \\
de retração $\left({ }^{\circ} \mathrm{C}\right)$ & $\mathrm{CO}$ & - & 1307 & 1314 & 1337 \\
& $\mathrm{MP}$ & 1242 & 1303 & 1332 & 1347 \\
\hline Retração linear total (\%) & $\mathrm{CP}$ & 20 & 22 & 21 & 22 \\
& $\mathrm{CO}$ & - & 19 & 17,5 & 16 \\
& $\mathrm{MP}$ & 24 & 24 & 22,6 & 16 \\
\hline \hline
\end{tabular}



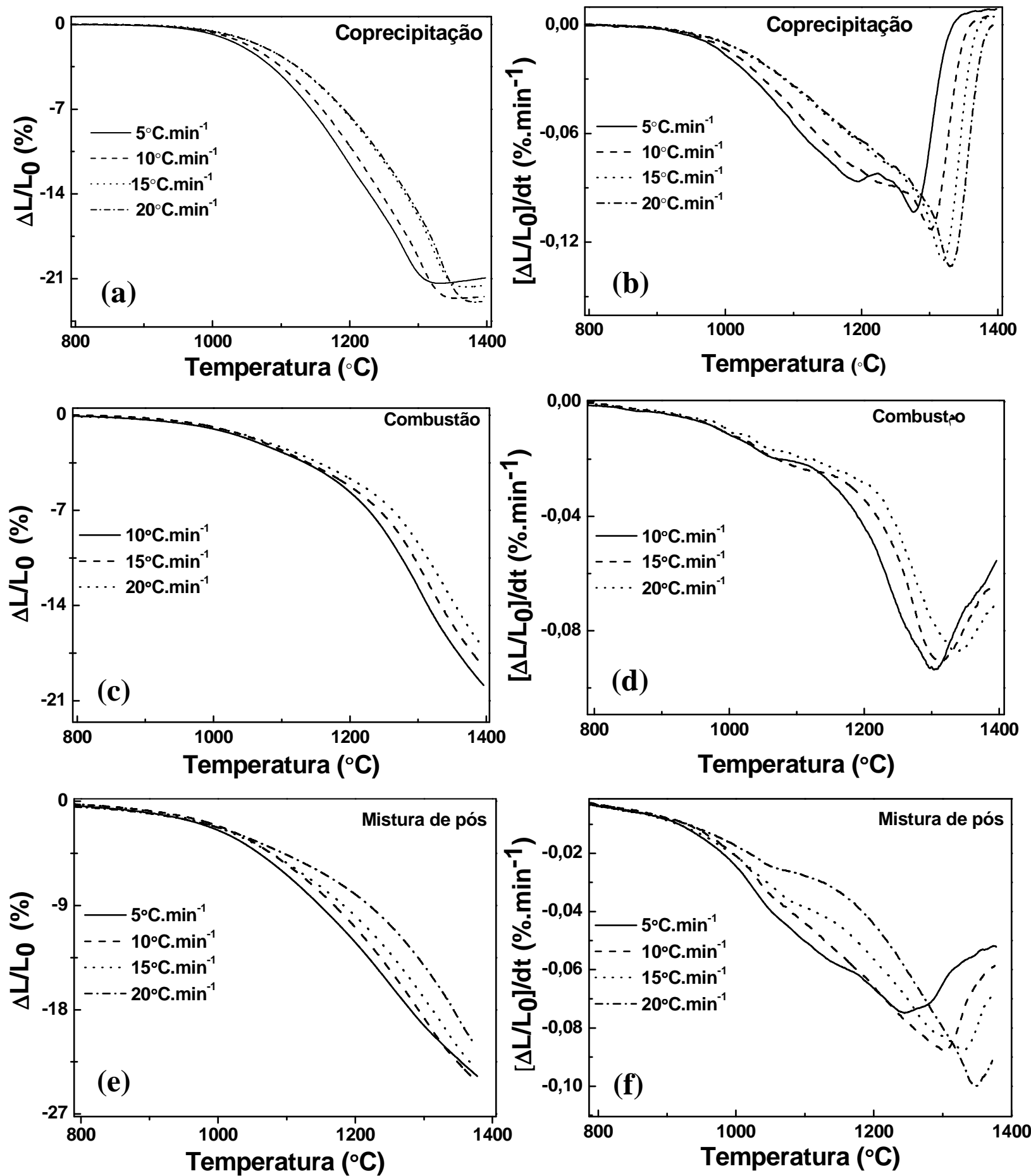

Figura 47 - Retração linear em função da temperatura para amostras de 56\% $\mathrm{NiO}$ YSZ submetidas a diferentes taxas de aquecimento $(5,10,15 \mathrm{e}$ $\left.20 \stackrel{\circ}{ } \mathrm{C} \cdot \mathrm{min}^{-1}\right)(\mathrm{a}, \mathrm{c}, \mathrm{e})$ e taxa de retração em função da temperatura de sinterização para amostras de $56 \% \mathrm{NiO}-\mathrm{YSZ}(\mathrm{b}, \mathrm{d}, \mathrm{f})$ 
Os valores de $\Delta \mathrm{L} / \mathrm{L}_{0}$ foram convertidos em densidade relativa utilizando a seguinte relação:

$$
\rho(T)=\left(\frac{L_{f}}{L(T)}\right)^{3} \rho_{f}
$$

onde: $\rho(T)$ é a densidade, $L_{f}$ é o comprimento final, $L(T)$ o comprimento para a temperatura correspondente e $\rho_{\mathrm{f}}$ indica a densidade final obtida pelo método de Archimedes.

Conforme esperado, nos três métodos de síntese, a maior densidade relativa foi obtida para amostra submetida à menor taxa de aquecimento, este comportamento está relacionado ao maior tempo em que a amostra é submetida ao processo de aquecimento. Na Fig.48 são apresentadas as curvas de retração convertidas em densidade relativa em função da temperatura, para amostras pelos três métodos, sob diferentes taxas de aquecimento, em atmosfera dinâmica de ar sintético.
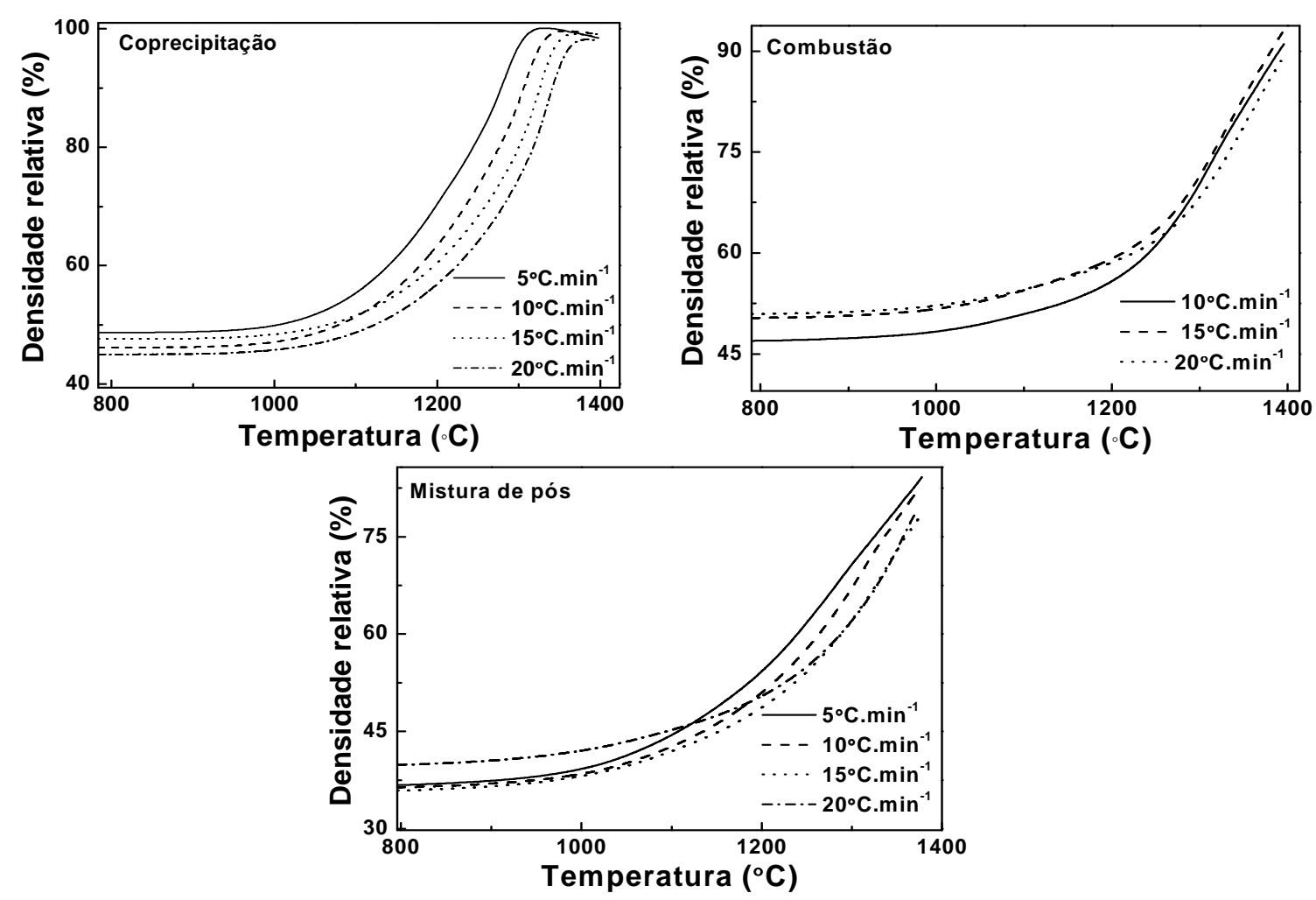

Figura 48 - Densidade relativa em função da temperatura de sinterização para amostras de NiO-YSZ cujos pós foram sintetizados por combustão, coprecipitação e mistura de pós 
Na Fig. 49.a é mostrada a evolução da taxa de densificacão em função da temperatura para as quatro taxas de aquecimento em amostras CP. Observa-se que o processo de densificação inicia-se acima de $800 \stackrel{\circ}{\circ}$ devido ao tratamento térmico prévio em que os pós foram submetidos. Acima desta temperatura a taxa instantânea de densificação, qualquer que seja a temperatura, será sempre maior em amostras que foram submetidas a taxas maiores de aquecimento. Na faixa de temperatura entre 1000 e $1200 \stackrel{\circ}{\circ}$, as amostras MP apresentam as maiores taxas de densificação em relação aos outros métodos. Os três métodos apresentam em comum a temperatura ao redor de $1300 \stackrel{\circ}{\circ}$ C como valor máximo de densificação. Marinsek et. al. [87], pelo método da combustão, obtiveram um valor de temperatura de $1200 \stackrel{\circ}{\circ} \mathrm{C}$ para máxima taxa de densificação.
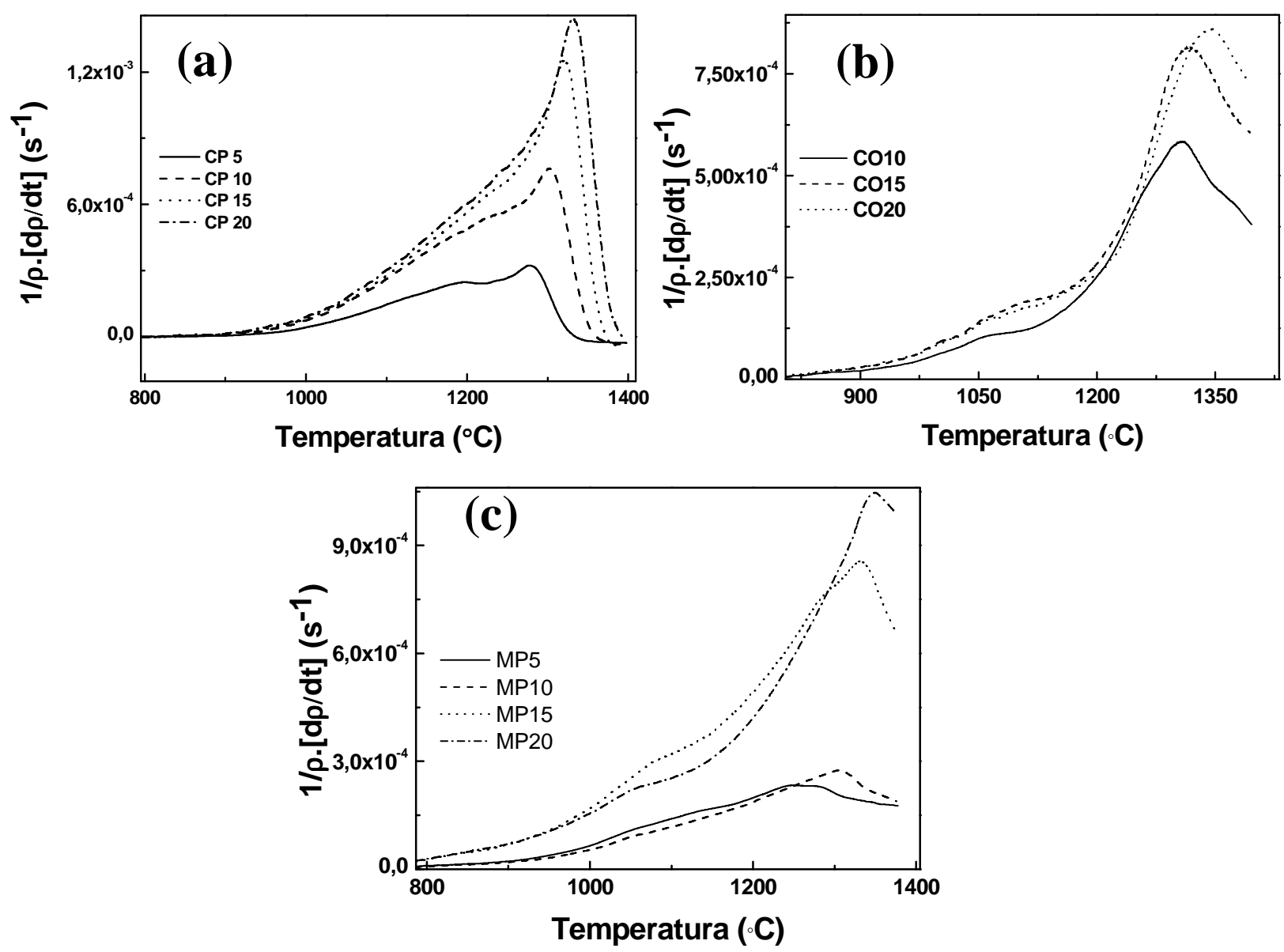

Figura 49 - Taxa de densificação em função da temperatura para amostras das séries $\mathrm{CO}, \mathrm{CP}$ e MP, obtidas em razão de aquecimento constantes de 5, 1015 e $20 \stackrel{\circ}{\circ}$. $\mathrm{min}^{-1}$ em atmosfera dinâmica de ar sintético. 
Os resultados apresentados na Fig. 50 comprovam a influência da densidade a verde no comportamento da sinterização. Sabe-se que amostras com densidades a verde maior geralmente resultam em uma menor retração devido à menor quantidade de poros que precisam ser removida durante a sinterização. A formação de aglomerados grandes durante o processo de sinterização também dificulta o processo de densificação da amostra.

Comparando os resultados de dilatometria (Fig. 50) de amostras obtidas pelos três métodos de sínteses, com taxa de aquecimento de 10 C.min ${ }^{-1}$, observa-se que as máximas taxa de densificação das amostras ficaram próximas a $1300^{\circ} \mathrm{C}$ (Fig. 50.a) e que a menor densid ade relativa foi obtida para a rota de mistura de pós (Fig. 50.b), resultado este possivelmente relacionado à heterogeneidade dos pós e formação de grandes aglomerados.
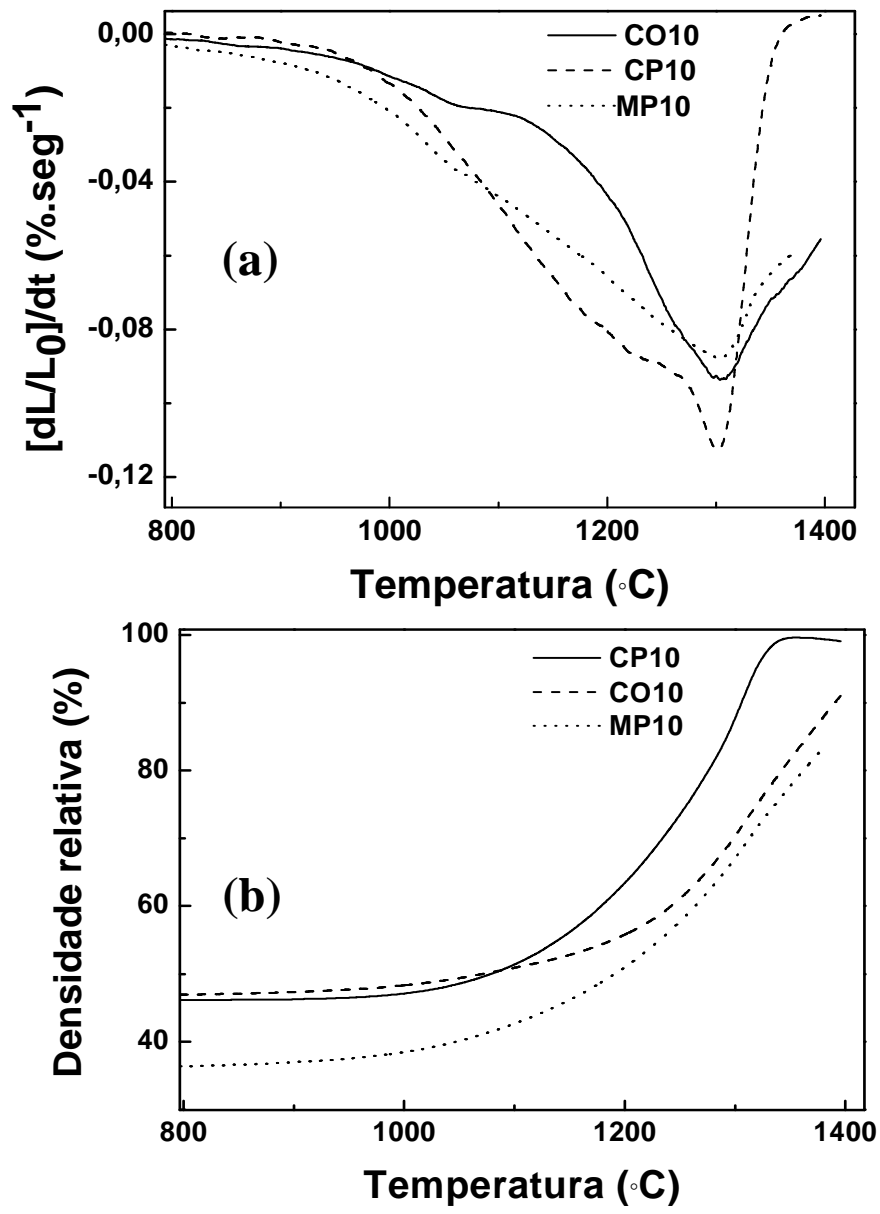

Figura 50 - Taxa de densificação em função da temperatura para amostras CO, CP e MP (a) e densidade relativa em função da temperatura (b), obtidas em taxa de aquecimento constante de $10^{\circ} \mathrm{C} \cdot \mathrm{min}^{-1}$, em atmosfera dinâmica de ar sintético. 
Na Fig. 51.a observa-se que a taxa de densificação da amostra CP tem um aumento significativo a partir de $1000^{\circ} \mathrm{C}$ e atinge uma densidade relativa de $88,5 \%$ na máxima taxa de densificação ao redor de $1300^{\circ} \mathrm{C}$, que também corresponde à temperatura em que ocorre a máxima taxa de densificação para outros dois métodos. Na amostra MP a densidade relativa é ligeiramente inferior à amostra CO (68,3\% comparado a 71,9\%).

Uma observação interessante é que mesmo apresentando diferentes valores de densidade a verde $\left(2,17 \mathrm{~g} \cdot \mathrm{cm}^{-3}\right.$ para amostra MP e 2,72 $\mathrm{g} \cdot \mathrm{cm}^{-3}$ para amostra CO), as amostra MP e CO (Fig. 51.b) apresentam a mesma taxa de densificação e praticamente o mesmo coeficiente angular até a temperatura de aproximadamente $1150 \stackrel{\circ}{\mathrm{C}}$.

No caso da amostra CP (Fig. 51.b) embora o valor de densidade a verde $\left(2,70 \mathrm{~g} . \mathrm{cm}^{-3}\right)$ seja ligeiramente inferior em relação à amostra $\mathrm{CO}$, observa-se uma taxa de densificação muito superior à de outras amostras, o que possivelmente está relacionado ao melhor empacotamento na compactação devido ao menor tamanho e uniformidade dos aglomerados fracos.
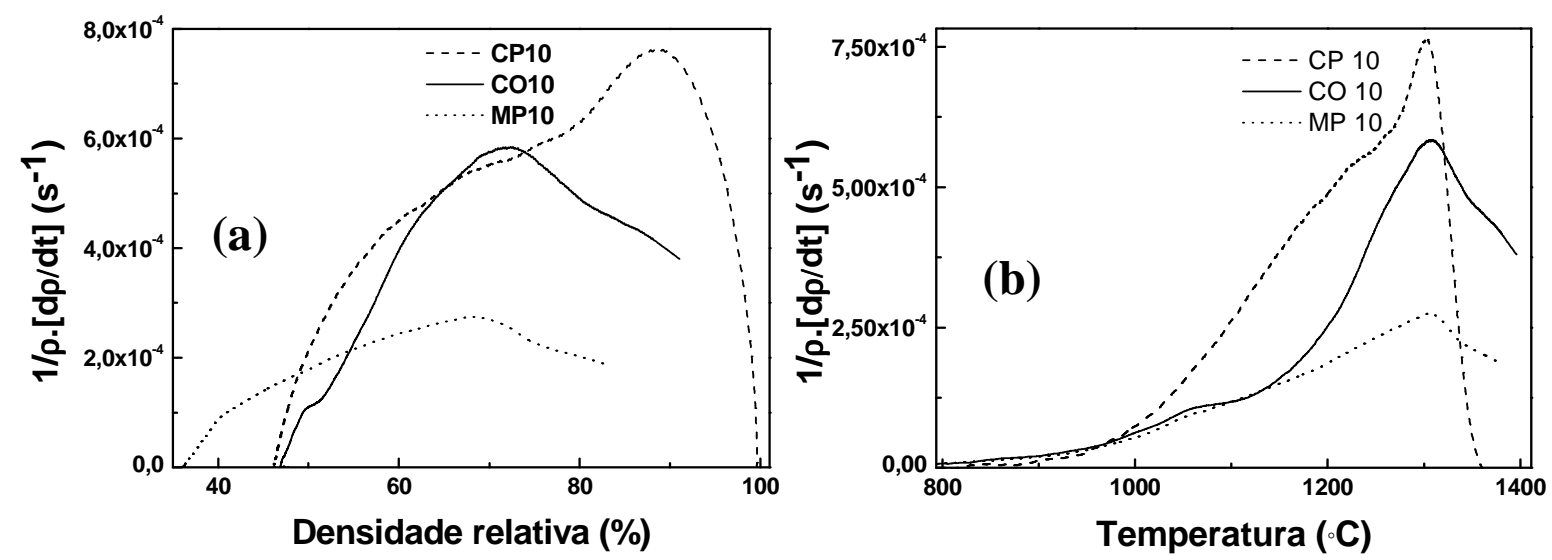

Figura 51 - Taxa de densificação em função da densidade relativa (a) e taxa de densificação em função da temperatura (b) para amostras CO, CP e MP, obtidas em taxa de aquecimento constante de $10^{\circ} \mathrm{C} \cdot \mathrm{min}^{-1}$, em atmosfera dinâmica de ar sintético.

Adotando-se a taxa de aquecimento de $10 \stackrel{\circ}{\circ} \mathrm{C} \cdot \mathrm{min}^{-1}$, as amostras foram sinterizadas, em forno tipo caixa, em ar atmosférico, para avaliação microestrutural em função da temperatura. 
A evolução da densificação e porosidade são apresentadas nos gráficos da Fig. 52. As curvas indicam que o processo de sinterização ocorreu em três estágios. No primeiro estágio, entre 1000 e $1200 \stackrel{\circ}{\circ}$, a porosidade é eliminada mais lentamente em relação ao segundo estágio. Na faixa entre 1200 e $1300 \stackrel{\circ}{\mathrm{C}}$, que corresponde ao estágio intermediário da sinterização, a variação da porosidade está entre 6\% e 13\%. No estágio final da sinterização entre 1400 e $1500 \stackrel{\circ}{\circ}$ a porosidade praticamente não sofre alteração e esses valores provavelmente estão relacionados com a formação de poros fechados.
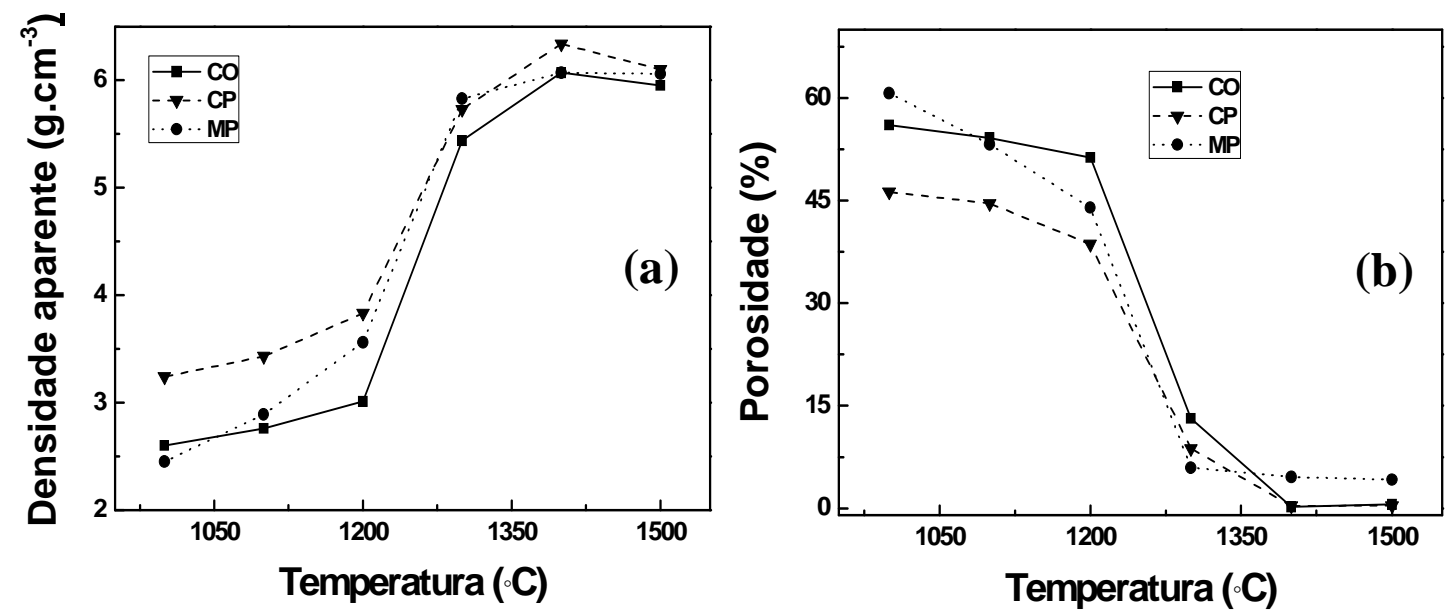

Figura 52 - Curvas de densidade aparente (a) e de porosidade, em função da temperatura (b) para amostras CO, CP e MP sinterizadas em forno caixa e aquecimento com taxa de $10{ }^{\circ} \mathrm{C} \cdot \mathrm{min}^{-1}$, sem isoterma.

A energia de ativação de densificação apresentada na Fig. 53 foi determinada a partir da retração linear das amostras obtidas em dilatômetro utilizando a equação abaixo e assumindo que o mecanismo dominante é a difusão por contorno de grão.

$$
\ln \left[\frac{d\left(\frac{\Delta L}{L_{0}}\right)}{d t} \cdot T\right]=A \cdot \frac{n E_{a}}{R T}
$$

Para obter os valores de energia de ativação, para os três métodos, foi escolhida a região onde a taxa de retração apresentava um comportamento linear, pois é um indicativo que apenas um mecanismo de sinterização está atuando. 
Pode-se observar pela Fig. 53 que os valores obtidos são muito próximos apesar da amostra MP apresentar densidade a verde menor. Este comportamento pode estar relacionado à maior influência das partículas $\mathrm{NiO}$ neste estágio da sinterização. Os valores obtidos estão dentro da faixa de

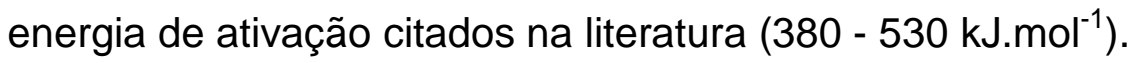

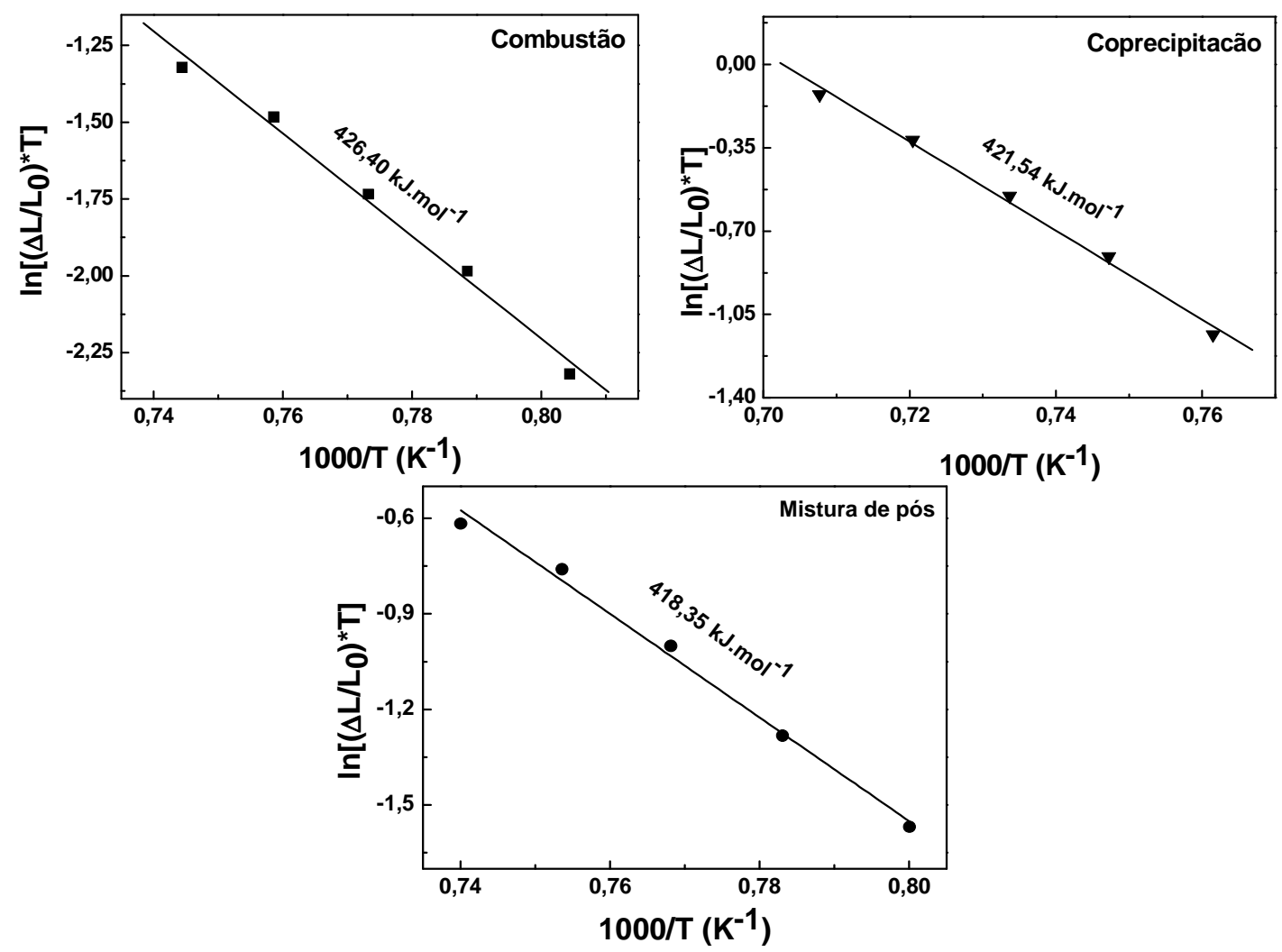

Figura 53 - Determinação da energia de ativação usando a relação de Arrhenius em função da temperatura (1/T) para amostras de NiO-YSZ obtidas por CO (a), CP (b) e MP (c) submetido a ensaio de dilatometria

$\mathrm{Na}$ Tab. 21 são apresentados as densidades dos materiais antes da sinterização e os parâmetros obtidos a partir da retração linear das amostras medidas no dilatômetro.

Para estudar a correlação entre os mecanismos de densificação e a evolução da microestrutura das amostras foi utilizado o método quasiisotérmico também chamado de "Stepwise Isothermal Dilatometry" (SID) [88]. 
Tabela 21 - Dados de sinterização obtidos a partir das medidas realizadas em dilatômetro

\begin{tabular}{cccc} 
AMOSTRA & CO & CP & MP \\
\hline Densidade relativa a verde (\%) & 43,0 & 42,1 & 34,2 \\
Temperatura de máxima taxa de & 1307 & 1303 & 1303 \\
retração $\left({ }^{\circ} \mathrm{C}\right)$ & & & \\
$\begin{array}{c}\text { Energia de ativação, } \mathrm{E}_{\mathrm{a}}\left(\mathrm{kJ} \cdot \mathrm{mol}^{-1}\right) \\
\text { Intervalo de temperatura }\left({ }^{\circ} \mathrm{C}\right)\end{array}$ & 426,40 & 421,54 & 418,35 \\
\hline \hline
\end{tabular}

A curva de retração linear de amostra obtida por coprecipitação em função do tempo e temperatura é apresentada na Fig. 54.a. A retração inicia-se a $898{ }^{\circ} \mathrm{C}$ e atinge seu valor máximo na isoterma de $1350{ }^{\circ} \mathrm{C}$.

Os dados da curva de retração linear foram convertidos em $\ln \{(\mathrm{dY} / \mathrm{dt}) /[\mathrm{Y} /(1-\mathrm{Y})]\}$ e $\ln [(1-\mathrm{Y}) / \mathrm{Y}]$ e plotados conforme Fig. 54.b. $\mathrm{O}$ comportamento linear para esta amostra, nos intervalos de isotermas entre 1000 e $1200 \stackrel{\circ}{\circ}$, indica que a equação de Makipirtti-Meng pode ser aplicada para esta faixa de temperatura. A descontinuidade na linearidade para isoterma acima de $1200 \stackrel{\circ}{\circ} \mathrm{C}$ e abaixo de $1000 \stackrel{\circ}{\circ}$ indica uma mudança no mecanismo de sinterização que não pode ser identificado por esta técnica.

$\mathrm{Na}$ amostra obtida por combustão, o intervalo de isoterma com comportamento linear é entre 900 e $1100^{\circ} \mathrm{C}$ e acima de $1150{ }^{\circ} \mathrm{C}$ a técnica não pode ser aplicada devido a não linearidade da curva. $\mathrm{Na}$ amostra obtida por mistura de pós, a faixa de temperatura com comportamento linear é entre 950 e $1150 \stackrel{\circ}{\circ}$. 

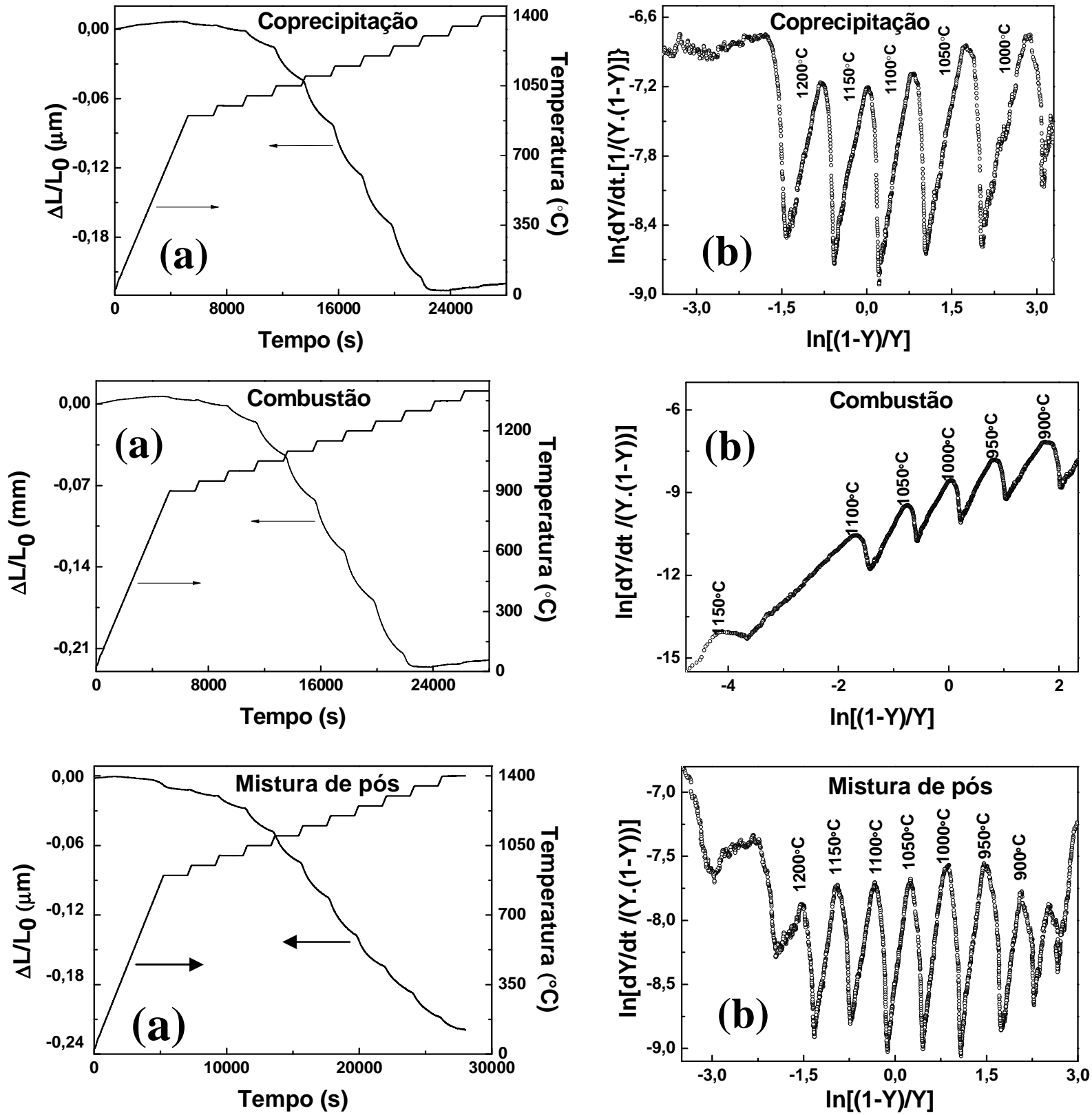

Figura 54 - Retração linear em função do tempo e temperatura (a) e curva de retração linear convertido em $\ln \{(\mathrm{dY} / \mathrm{dt}) / \quad[\mathrm{Y} /(1-\mathrm{Y})]\}$ e $\ln [(1-\mathrm{Y}) / \mathrm{Y}]$ conforme equação de Makipirtti-Meng (b)

Do coeficiente angular da reta da isoterma é calculado o valor do expoente $\mathrm{n}$ e na interceptação da reta $\mathrm{o}$ valor de $\mathrm{ln} \mathrm{k}$, os resultados são apresentados na Tab. 22 para o método de coprecipitação, Tab. 23 para combustão e Tab. 24 para mistura de pós. 
Para o estágio inicial de sinterização o mecanismo de transporte de massa sob condições de isoterma é controlado por uma das etapas de difusão que pode ser expresso por [57]:

Para difusão por volume do contorno de grão:

$$
\frac{\mathrm{d}\left(\frac{\Delta \mathrm{L}}{\mathrm{L}_{0}}\right)}{\mathrm{dt}}=\left[\frac{5,34 \gamma \Omega \mathrm{D}_{\mathrm{V}}}{\mathrm{kTG}^{3}}\right]^{\mathrm{n}} \cdot \mathrm{t}^{(\mathrm{n}-1)}
$$

onde: $\mathrm{n}=0,49$

Para difusão por contorno de grãos:

$$
\frac{\mathrm{d}\left(\frac{\Delta \mathrm{L}}{\mathrm{L}_{0}}\right)}{\mathrm{dt}}=\left[\frac{2,14 \gamma \Omega \mathrm{D}_{\mathrm{V}}}{\mathrm{kTG}^{3}}\right]^{\mathrm{n}} \cdot \mathrm{t}^{(\mathrm{n}-1)}
$$

onde: $\mathrm{n}=0,33$

Tabela 22 - Dados obtidos da equação de Makipirtti-Meng para análise da cinética de sinterização para amostra obtida pelo método da coprecipitação

\begin{tabular}{cccccc}
$\mathrm{T}\left({ }^{\circ} \mathrm{C}\right)$ & $10^{3} / \mathrm{T}\left(\mathrm{K}^{-1}\right)$ & $\ln (\mathrm{nk})$ & $1 / \mathrm{n}$ & $\mathrm{n}$ & $\operatorname{lnk}$ \\
\hline & & & & & \\
900 & 0,852515 & $-11,79654$ & 1,18256 & 0,84562 & $-11,62886$ \\
950 & 0,817661 & $-11,60972$ & 1,20123 & 0,83248 & $-11,42637$ \\
1000 & 0,785546 & $-13,00102$ & 2,21789 & 0,45088 & $-12,20446$ \\
1050 & 0,755858 & $-11,39547$ & 2,66977 & 0,37456 & $-10,41348$ \\
1100 & 0,728332 & $-9,54147$ & 3,23528 & 0,30909 & $-8,36735$ \\
1150 & 0,702741 & $-7,14295$ & 2,61546 & 0,38234 & $-6,18151$ \\
1200 & 0,678887 & $-5,39994$ & 2,19005 & 0,45661 & $-4,61602$ \\
1250 & 0,656599 & $-6,76509$ & 0,0349 & 28,6533 & $-10,12036$ \\
\hline
\end{tabular}


Tabela 23 - Dados obtidos da equação de Makipirtti-Meng para análise da cinética de sinterização para amostra obtida pelo método da combustão

\begin{tabular}{cccccc}
$\mathrm{T}\left({ }^{\circ} \mathrm{C}\right)$ & $10^{3} / \mathrm{T}\left(\mathrm{K}^{-1}\right)$ & $\ln (\mathrm{nk})$ & $1 / \mathrm{n}$ & $\mathrm{n}$ & $\operatorname{Ink}$ \\
\hline \hline & & & & & \\
900 & 0,852515 & $-13,9299$ & 3,11158 & 0,32138 & $-12,79477$ \\
950 & 0,817661 & $-12,35484$ & 3,00189 & 0,33312 & $-11,2556$ \\
1000 & 0,785546 & $-11,21002$ & 3,62359 & 0,27597 & $-9,92255$ \\
1050 & 0,755858 & $-8,45872$ & 2,28701 & 0,43725 & $-7,63147$ \\
1100 & 0,728332 & $-6,30468$ & 2,8441 & 0,35161 & $-5,25943$ \\
1150 & 0,702741 & $-6,5243$ & 1,14572 & 0,87281 & $-6,38827$ \\
1200 & 0,678887 & $-7,10186$ & 0,15919 & 6,2818 & $-8,93952$ \\
\hline
\end{tabular}

Tabela 24 - Dados obtidos da equação de Makipirtti-Meng para análise da cinética de sinterização para amostra obtida pelo método da mistura de pós

\begin{tabular}{cccccc}
\hline \hline$\left({ }^{\circ} \mathrm{C}\right)$ & $10^{3} / \mathrm{T}\left(\mathrm{K}^{-1}\right)$ & $\ln (\mathrm{nk})$ & $1 / \mathrm{n}$ & $\mathrm{n}$ & $\operatorname{lnk}$ \\
\hline & & & & & \\
900 & 0,852515 & $-15,73792$ & 3,88655 & 0,2573 & $-14,3804$ \\
950 & 0,817661 & 13,73792 & 3,85014 & 0,25973 & $-12,38981$ \\
1000 & 0,785546 & $-10,82682$ & 4,07963 & 0,24512 & $-9,42081$ \\
1050 & 0,755858 & $-8,51333$ & 3,80644 & 0,26271 & $-7,17664$ \\
1100 & 0,728332 & $-6,70566$ & 2,89585 & 0,34532 & $-5,64238$ \\
1150 & 0,702741 & $-4,75598$ & 3,1113 & 0,32141 & $-3,62094$ \\
1200 & 0,678887 & $-6,96596$ & 0,65926 & 1,51685 & $-7,3826$ \\
\hline
\end{tabular}

A grande variação no valor de n no intervalo de temperatura entre $900 \mathrm{e}$ $1000{ }^{\circ} \mathrm{C}$ e a $1250 \stackrel{\circ}{\circ}$, para amostra $\mathrm{CP}$, indica que ocorreram diferentes mecanismos de sinterização nesta faixa de temperatura. Entre 1050 e $1150{ }^{\circ} \mathrm{C}$ o mecanismo dominante é a difusão pelo contorno de grãos e na isoterma de 
$1200 \stackrel{\circ}{\circ}$ o mecanismo dominante é a difusão por volume e para temperaturas superiores, o método não pode ser aplicado, pois ocorrem mecanismos simultâneos que fogem do comportamento linear.

No estágio inicial de sinterização para amostra $\mathrm{CO}$, o mecanismo de transporte de massa sob condições de isoterma entre 900 e $1000 \stackrel{\circ}{\circ} \mathrm{C}$ é controlado pelo mecanismo de difusão por contorno de grãos cujo valor de $\mathrm{n}$ é 0 ,33. O mecanismo de difusão por contorno de grão na amostra MP ocorre a partir de $1100 \stackrel{\circ}{\circ}$.

Na Fig.55 é apresentado o gráfico de In $\mathrm{k}$ em função de 1/T conforme equação de Arrhenius a partir de dados apresentado nas Tabelas 21, 22 e 23. A energia de ativação para amostra CP foi calculada a partir do coeficiente angular da reta obtida na faixa de temperatura entre 950 - $1200^{\circ} \mathrm{C}$. A energia obtida neste intervalo foi de $457,12 \mathrm{~kJ}$.mol. A densidade relativa no estágio final da sinterização é de $95,0 \%$.

A energia de ativação da amostra $\mathrm{CO}$ foi determinada no intervalo entre 950 e $1100 \stackrel{\circ}{\circ}$ e o valor obtido foi de $497,28 \mathrm{~kJ} \cdot \mathrm{mol}^{-1}$. O mecanismo de ativação neste intervalo passa de difusão por contorno de grão para difusão por volume a $1050 \stackrel{\circ}{\circ}$. Acima de $1150 \stackrel{\circ}{\circ}$ o método não pode ser mais utilizado. A densidade relativa da amostra depois do ensaio é de 93,4\%

$\mathrm{Na}$ amostra MP até a temperatura de $1100 \stackrel{\circ}{\mathrm{C}}$ não há um mecanismo dominante, provavelmente ocorreram diversos mecanismos simultâneos. $\mathrm{Na}$ temperatura entre 1100 e $1150 \stackrel{\circ}{\circ}$ o mecanismo dominante é da difusão por contorno de grão e a energia de ativação de $570,37 \mathrm{~kJ} \mathrm{~mol}^{-1}$. Segundo Tietz et al. [38] este valor de energia de ativação pode ser atribuído à sinterização do YSZ, pois neste caso, o $\mathrm{NiO}$ não contribui significativamente para o processo de sinterização. Acima desta faixa de temperatura o método não pode ser utilizado. A densidade relativa final da amostra atingiu um valor de $84,4 \%$. 

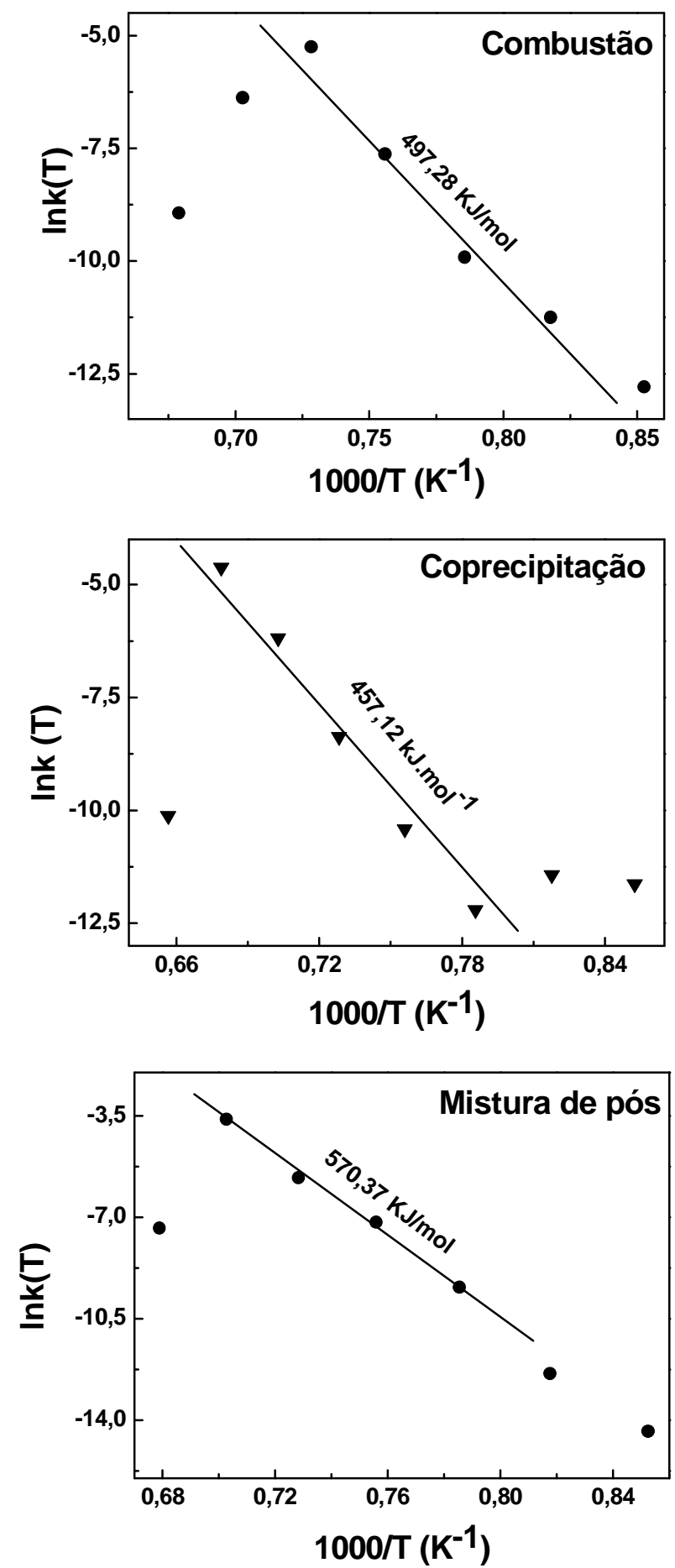

Figura 55 - Constante de Arrhenius k (T) em função da temperatura (1/T) para amostras de NiO-YSZ submetidas a ensaios de dilatometria

$\mathrm{Na}$ Tab. 25 é apresentada a densidade a verde das amostras, a retração linear total a $1400 \stackrel{\circ}{\circ}$ e os valores de energia de ativação com as respectivas faixas de temperatura. 
Tabela 25 - Densidade a verde das amostras obtidas pelo método da combustão (CO), coprecipitação (CP) e mistura de pós (MP), retração linear e a energia de ativação de sinterização.

\begin{tabular}{|c|c|c|c|}
\hline AMOSTRA & $\mathrm{CO}$ & $\mathrm{CP}$ & MP \\
\hline $\begin{array}{l}\text { Densidade relativa a verde } \\
\qquad(\%)\end{array}$ & 42,0 & 42,0 & 42,0 \\
\hline $\begin{array}{l}\text { Energia de ativação, } \mathrm{E}_{\mathrm{a}} \\
\qquad\left(\mathrm{kJ} \cdot \mathrm{mol}^{-1}\right)\end{array}$ & 497,28 & 457,12 & 570,37 \\
\hline $\begin{array}{c}\text { Retração linear a } 1400{ }^{\circ} \mathrm{C} \\
(\%)\end{array}$ & 22,6 & 22,6 & 22,8 \\
\hline $\begin{array}{l}\text { Intervalo de temperatura } \\
\qquad\left({ }^{\circ} \mathrm{C}\right)\end{array}$ & $950-1100$ & $950-1150$ & $950-1150$ \\
\hline
\end{tabular}

No estudo de sinterização de amostras de NiO-YSZ com uma composição de $40 \%$ em massa de $\mathrm{NiO}$, apresentado por Grgicak et al. [57], a energia de ativação obtida foi de $530 \mathrm{~kJ}^{\mathrm{mol}}{ }^{-1} \mathrm{e}$ o mecanismo dominante foi de difusão por contorno de grão. No estudo apresentado por Tietz et al. [38], para avaliação de pós comerciais, a energia de ativação variou entre 472 e 527 $\mathrm{kJ} \cdot \mathrm{mol}^{-1}$. Esta variação nos valores da energia de ativação está relacionada às características dos pós de $\mathrm{NiO}$ e concentração em massa deste óxido, uma vez que no estudo de Tietz foram avaliados pós de $\mathrm{NiO}$ de diversas procedências, fixando-se o pó de YSZ.

Nas micrografias da Fig. 56 são apresentadas as microestruturas das superfícies de fratura dos compósitos NiO-YSZ sintetizados por coprecipitação e sinterizados a 1200, 1300 e $1400^{\circ} \mathrm{C}$. Na amostra submetida à sinterização a $1200{ }^{\circ} \mathrm{C}$ é possível observar uma distribuição relativamente homogênea de poros interconectados, comprovando a baixa densidade relativa $(59,8 \%)$ e porosidade de $38,5 \%$, valores obtidos utilizando a norma C20-00. Na amostra sinterizada a $1300{ }^{\circ} \mathrm{C}$ a área de contato das partículas aumenta e ocorre uma diminuição na porosidade $(11,5 \%)$ e são observadas pequenas regiões isoladas de poros interconectados e também a presença de poros isolados com aspecto arredondado. $\mathrm{Na}$ amostra sinterizada a $1400{ }^{\circ} \mathrm{C}$ a densidade relativa 
da amostra atinge $98,4 \%$ e porosidade de $0,6 \%$. Este mesmo comportamento foi observado para os outros métodos de síntese.

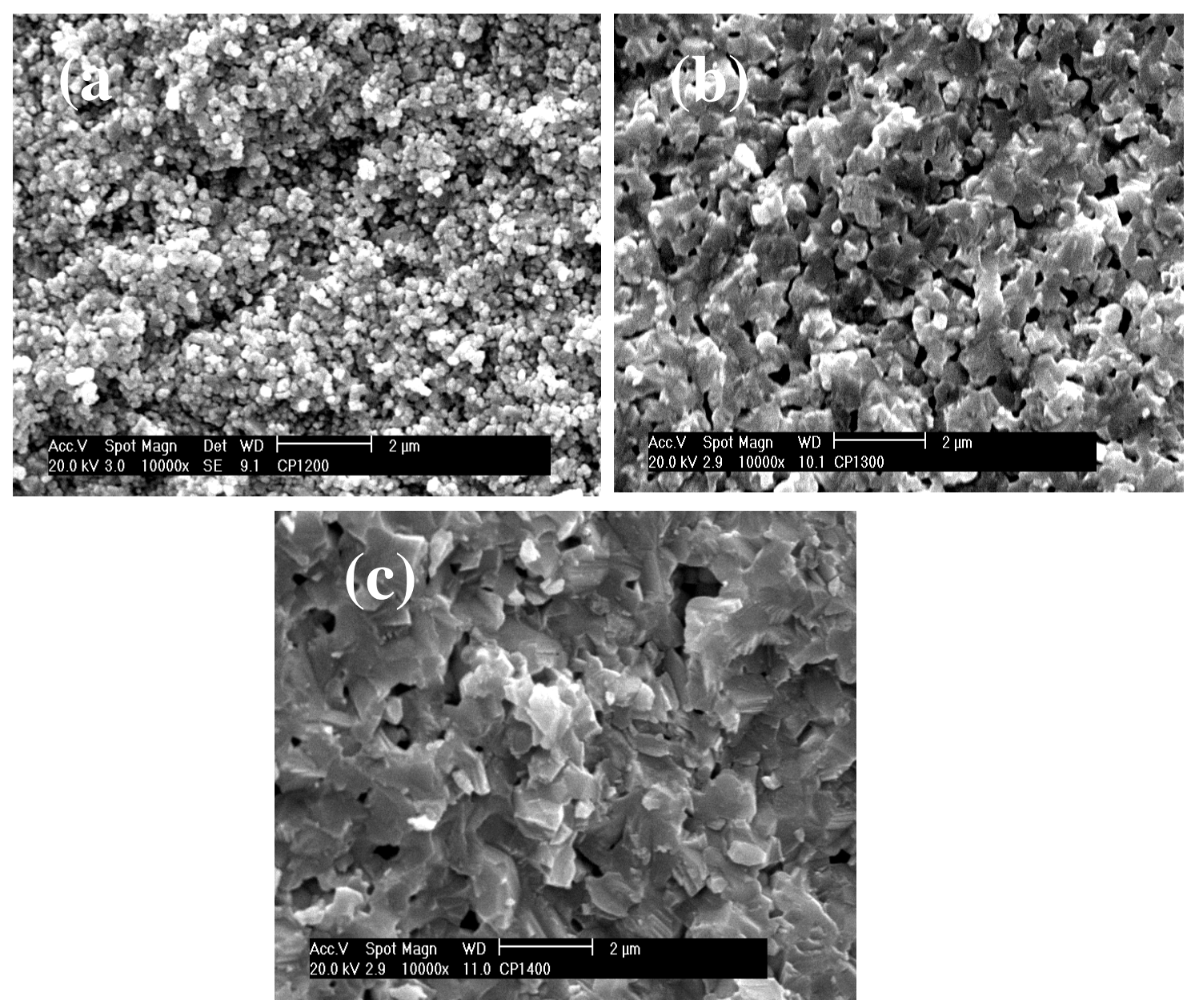

Figura 56 - Micrografias obtidas por MEV das superfícies de fratura de amostras cerâmicas de 56\% NiO:YSZ sintetizadas por coprecipitação (CP) e sinterizadas a $1200^{\circ} \mathrm{C}$ (a) e $1300^{\circ} \mathrm{C}$ (b) e $1400^{\circ} \mathrm{C} \quad$ (c), adotando-se taxa de aquecimento de $10^{\circ} \mathrm{C} \cdot \mathrm{min}^{-1}$.

Nas micrografias da Fig. 57 observa-se uma razoável homogeneidade das fases $\mathrm{NiO}$ (cinza escuro) e YSZ (cinza claro) em toda extensão das amostras sinterizadas a 1300 e $1400{ }^{\circ} \mathrm{C}$. O aument o no tamanho dos grãos com o aumento da temperatura de sinterização confirma que acima da temperatura de máxima taxa de retração predomina o processo de crescimento dos grãos. 

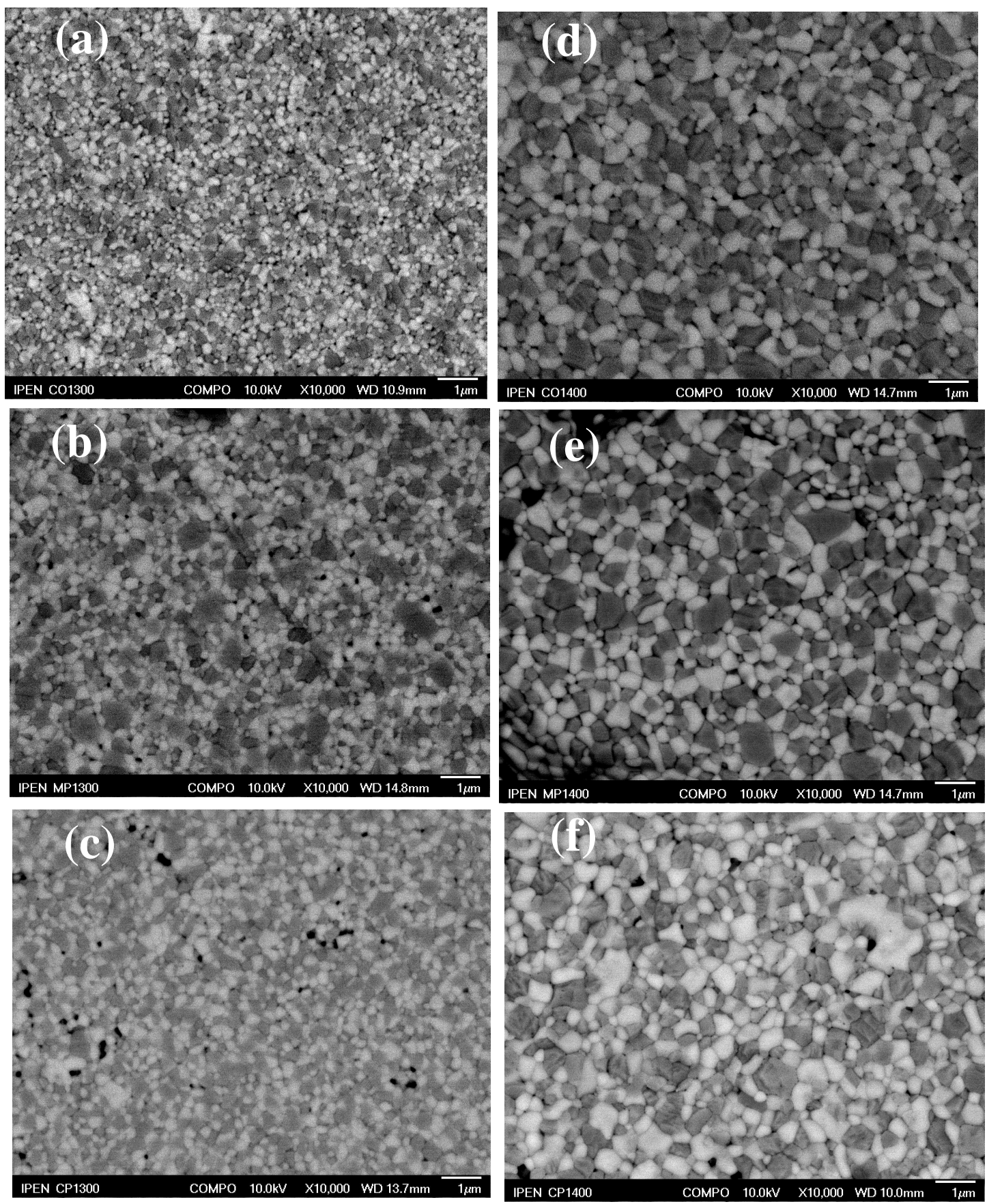

Figura 57 - Micrografias obtidas por MEV das superfícies polidas e submetidas a ataque térmico de amostras cerâmicas de 56\%NiO:YSZ sintetizadas por mistura de pós (a e d), combustão (b e e) e coprecipitação (c e f) e sinterizadas a 1300 e $1^{1400} \mathrm{C}$

\section{V.4.2 - Estudo de redução do NiO pelo hidrogênio}

A redução do óxido de níquel ocorre segundo a reação: 


$$
\mathrm{NiO}_{(\mathrm{s})}+\mathrm{H}_{2(\mathrm{~g}) \rightarrow \mathrm{Ni}_{(\mathrm{s})}}+\mathrm{H}_{2} \mathrm{O}_{(\mathrm{g})}
$$

No processo de redução a alta temperatura $\left(800-900{ }^{\circ} \mathrm{C}\right)$, a água formada é rapidamente removida e ao mesmo tempo o átomo de níquel difunde rapidamente na superfície do óxido de níquel. A dissociação do hidrogênio começa no instante em que o aglomerado de níquel atinge um determinado tamanho, e a partir deste ponto a redução é acelerada auto cataliticamente [113].

Conforme a Fig. 57, a cinética de redução avaliada em função de perda de massa por análise termogravimétrica para os pós obtidos pelos três métodos de síntese e sinterizados a $1350 \stackrel{\circ}{\circ}$ por 1 hora indicou uma perda de massa lenta até a temperatura de aproximadamente $420 \stackrel{\circ}{\circ}$. Acima desta temperatura a perda de massa para os pós obtidos pelo método de combustão ocorreu até a completa redução do óxido de níquel ao redor de $700{ }^{\circ} \mathrm{C}$, enquanto que nos outros dois métodos a redução total ocorre ao redor de $900 \stackrel{\circ}{ } \mathrm{C}$.
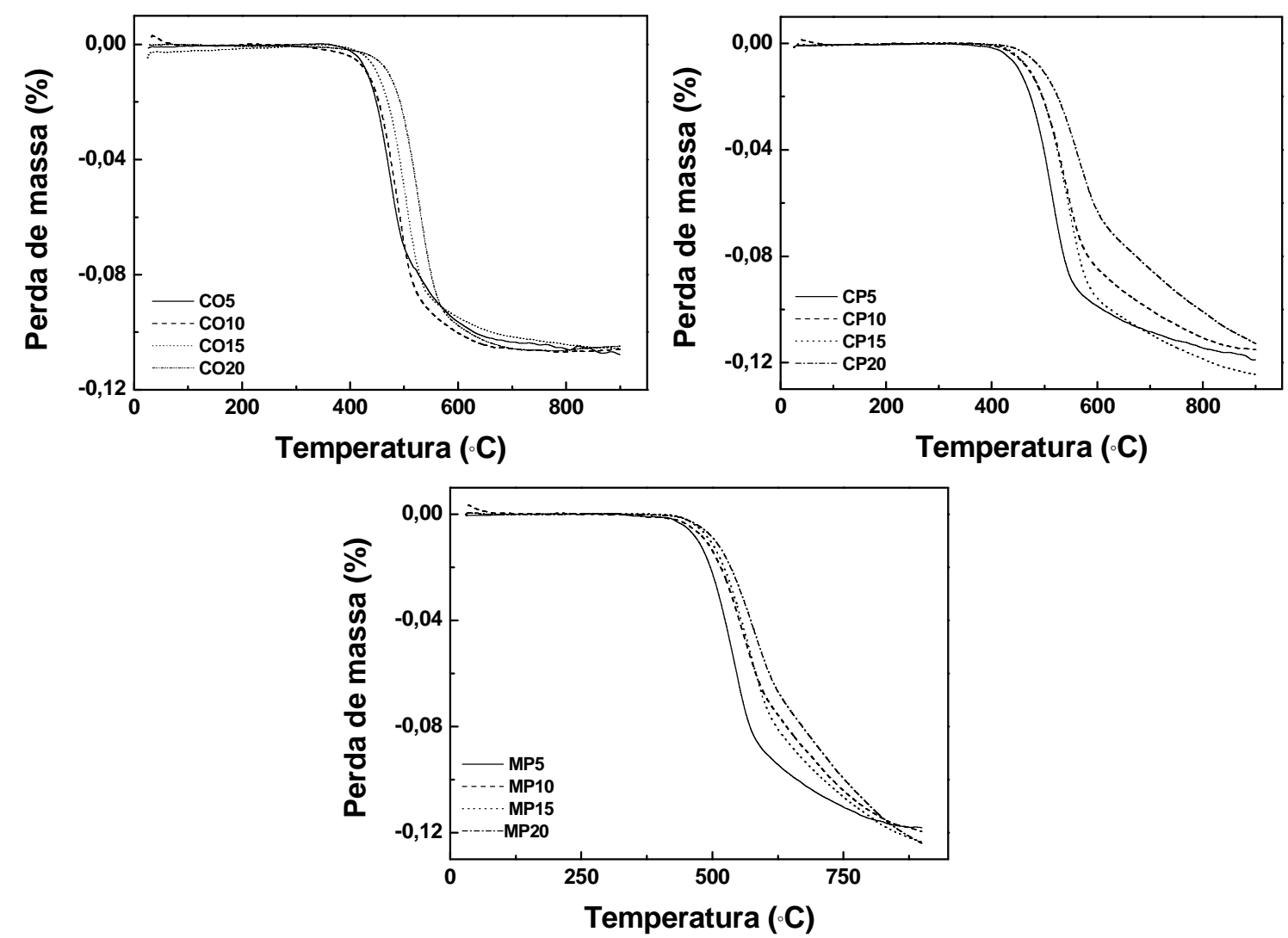

Figura 58 - Perda de massa em função da temperatura para amostras obtidas pelos três métodos de síntese submetidas a uma vazão de $100 \mathrm{~mL}$. $\mathrm{min}^{-1}$ em atmosfera dinâmica de $20 \%$ de $\mathrm{H}_{2}$ em balanço com Ar e diferentes taxa de aquecimentos $\left(5,10,15\right.$ e $\left.20 \stackrel{\circ}{ } \mathrm{C} \cdot \mathrm{min}^{-1}\right)$. 
Os valores de temperatura na máxima taxa de redução foram determinados a partir das curvas da derivada da TG (DTG) (Fig. 59). Observase pelas curvas DTG que a temperatura na máxima taxa de retração aumenta com o aumento da taxa de aquecimento. Os valores são apresentados na Tab. 26.
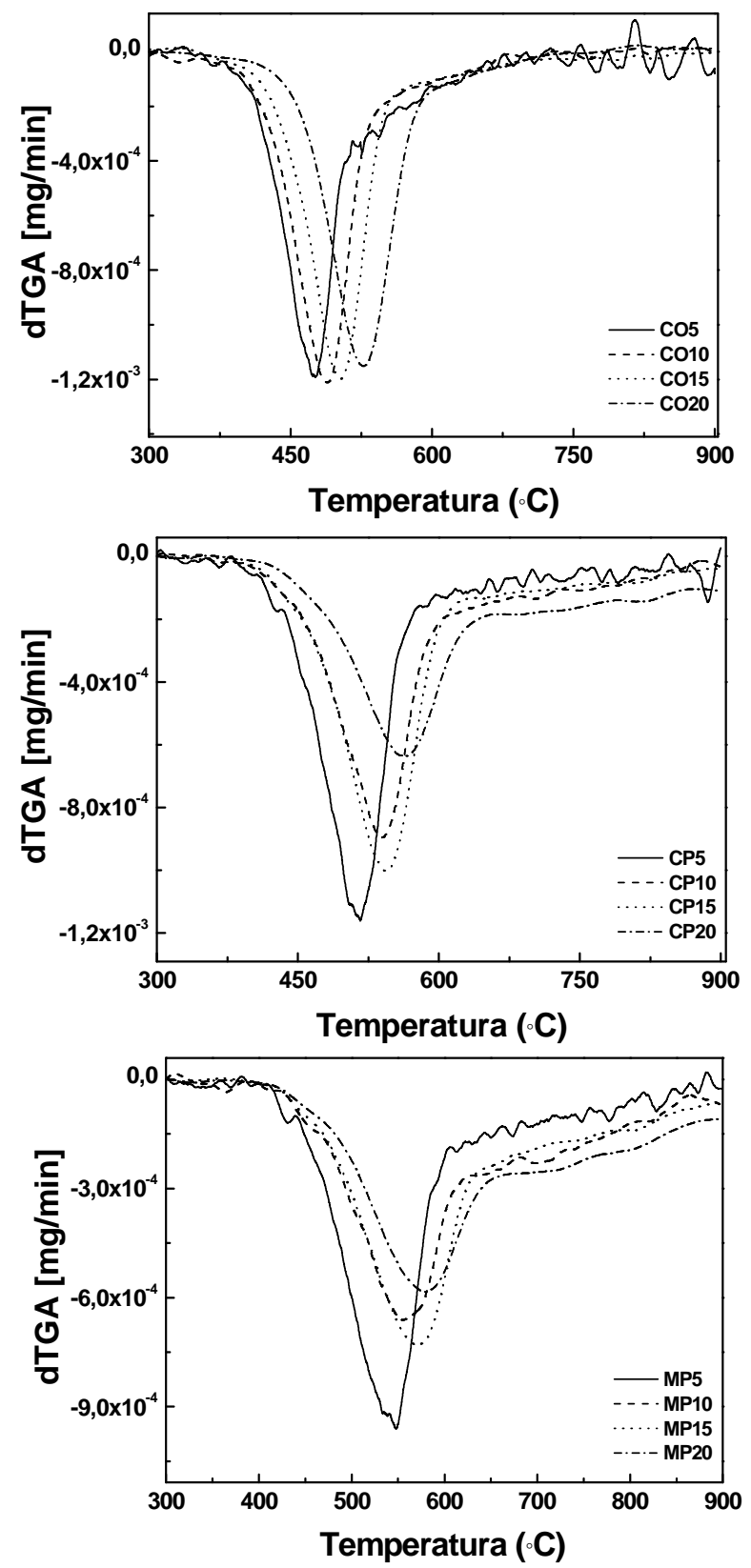

Figura 59 - Taxa de redução em função da temperatura para amostras obtidas pelos três métodos de síntese submetidas a uma vazão de $100 \mathrm{~mL} \cdot \mathrm{min}^{-1}$ em atmosfera dinâmica de $20 \%$ de $\mathrm{H}_{2}$ em balanço com $\mathrm{Ar}$ e diferentes taxa de aquecimentos $\left(5,10,15\right.$ e $\left.20 \stackrel{\circ}{\circ} \mathrm{C} \cdot \mathrm{min}^{-1}\right)$ 
Tabela 26 - Temperatura onde ocorre a máxima taxa de redução para diferentes taxas de aquecimento $\left(5,10,15\right.$ e $\left.20 \stackrel{\circ}{\circ} \mathrm{C} \cdot \mathrm{min}^{-1}\right)$ e valores de taxa de redução obtida na região mais linear da curva.

\begin{tabular}{cccccc} 
Parâmetro avaliado & Método de & \multicolumn{4}{c}{ Razão de aquecimento $\left({ }^{\circ} \mathrm{C} \cdot \mathrm{min}^{-1}\right)$} \\
\cline { 4 - 7 } & síntese & 5 & 10 & 15 & 20 \\
\hline \hline Temperatura de máxima taxa & $\mathrm{CO}$ & 475,0 & 488,9 & 502,7 & 527,4 \\
de redução $\left({ }^{\circ} \mathrm{C}\right)$ & $\mathrm{CP}$ & 516,9 & 540,3 & 543,9 & 565,6 \\
& $\mathrm{MP}$ & 548,2 & 554,3 & 571,4 & 579,8 \\
\hline Taxa de redução $\left(\mathrm{mg}^{\left.-\mathrm{min}^{-1}\right)}\right.$ & $\mathrm{CO}$ & 0,066 & 0,137 & 0,176 & 0,400 \\
& $\mathrm{CP}$ & 0,070 & 0,134 & 0,176 & 0,162 \\
& $\mathrm{MP}$ & 0,062 & 0,081 & 0,144 & 0,158 \\
\hline \hline
\end{tabular}

A energia de ativação $E_{a}$ relatada na literatura para redução do óxido de níquel no compósito NiO-YSZ varia entre 78 e $94 \mathrm{~kJ} \cdot \mathrm{mol}^{-1}$ e a redução ocorre na faixa de temperatura entre 500 e $950 \stackrel{\circ}{\circ}[116,120]$. Neste estudo, os valores de energia de ativação para redução do óxido de níquel a partir de dados da TG, com taxa de aquecimento constante, foi calculada usando a seguinte equação:

$$
\ln \left(\frac{\alpha}{T_{m}^{2}}\right)=\frac{E_{a}}{R T_{m}}+\ln \left(\frac{R k_{0}}{E_{a}}\right)
$$

$\mathrm{Na}$ Fig. 60 observa-se que os valores de energia de ativação das amostras dos pós obtidos pelo método de coprecipitação e mistura de pós ficaram acima da média citadas, 143,21 e 141,89 kJ.mol${ }^{-1}$, respectivamente. Esses valores provavelmente estão relacionados ao maior crescimento no tamanho dos grãos durante o tratamento térmico. Nos pós obtidos por coprecipitação pode ter ocorrido também uma maior interação do óxido de níquel com o suporte zircônia. A sinterização em temperatura de $1350 \stackrel{\circ}{\mathrm{C}}$ por 1 hora faz com que haja um maior crescimento no tamanho dos grãos devido à coalescência dos grãos de óxido de níquel e maior interação com o suporte zircônia. 


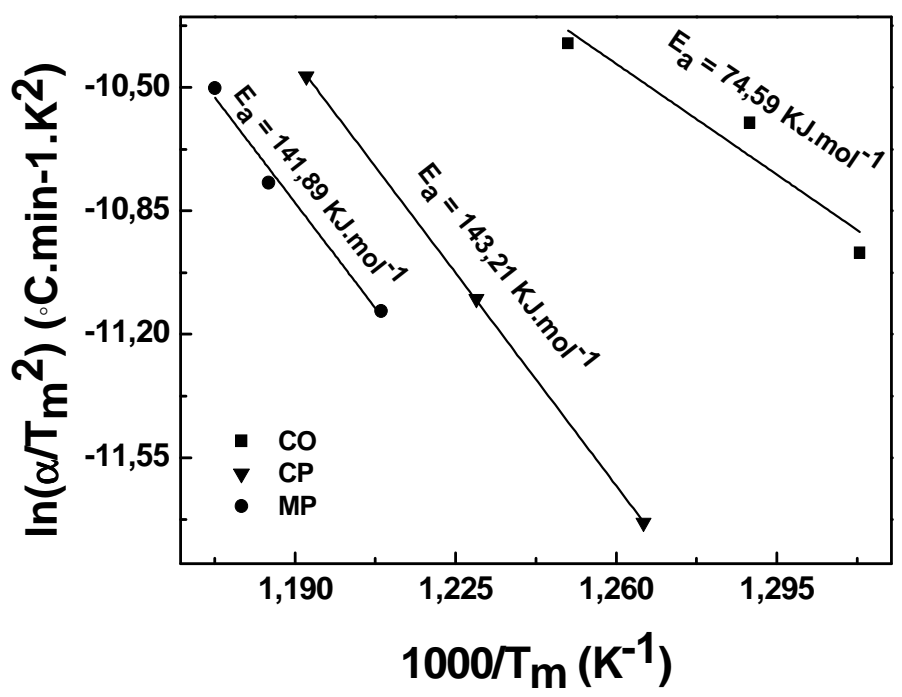

Figura 60 - Gráfico de Ahrrenius da taxa de redução em função da temperatura, para amostras obtidas pelos três métodos de síntese submetidas a uma vazão de 100mL.min ${ }^{-1}$ em atmosfera dinâmica de $20 \%$ de $\mathrm{H}_{2}$ em balanço com $\mathrm{Ar}$ e taxas de aquecimentos $\left(10,15\right.$ e $\left.20^{\circ} \mathrm{C} \cdot \mathrm{min}^{-1}\right)$.

$\mathrm{Na}$ micrografia do pó calcinado a $1350^{\circ} \mathrm{C}$ por 1 hora obtido pelo método de combustão (Fig. 61) é possível observar que os aglomerados são formados por pequenos grãos ao contrário do pó obtido pelo método de mistura de pós (Fig. 62) que é formado por grãos maiores. A energia de ativação da

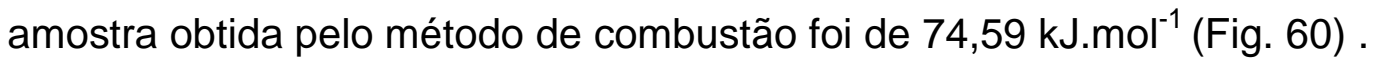

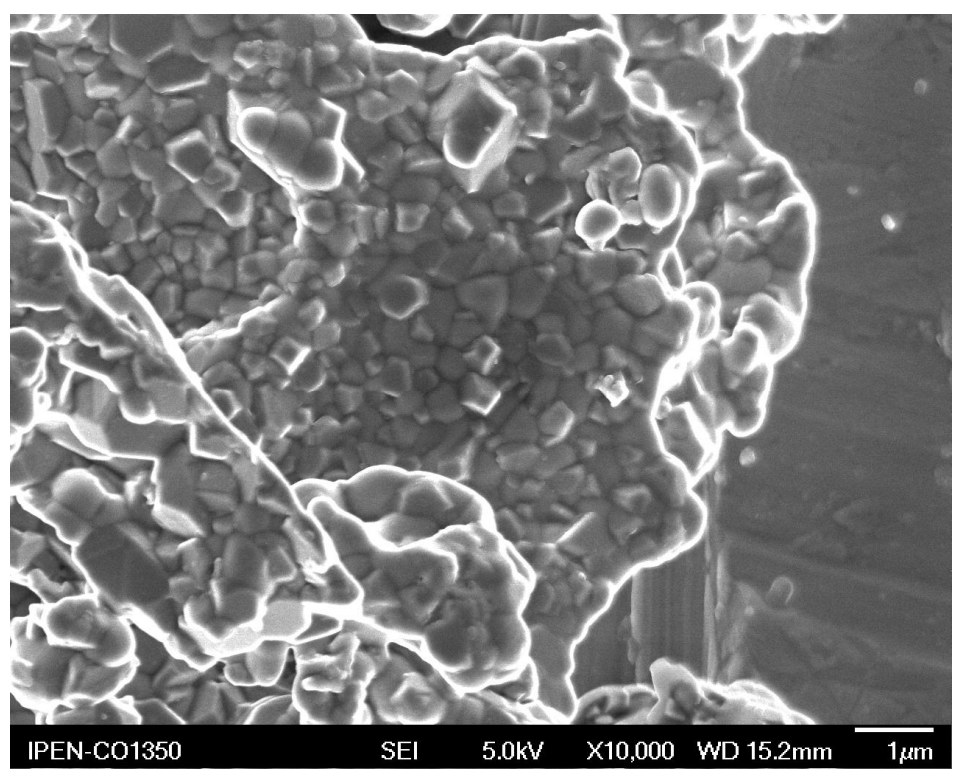

Figura 61 - Micrografia (MEV) do pó calcinado a $1350 \stackrel{\circ}{\mathrm{C}}$ por 1 hora obtido pelo método de combustão (CO) 


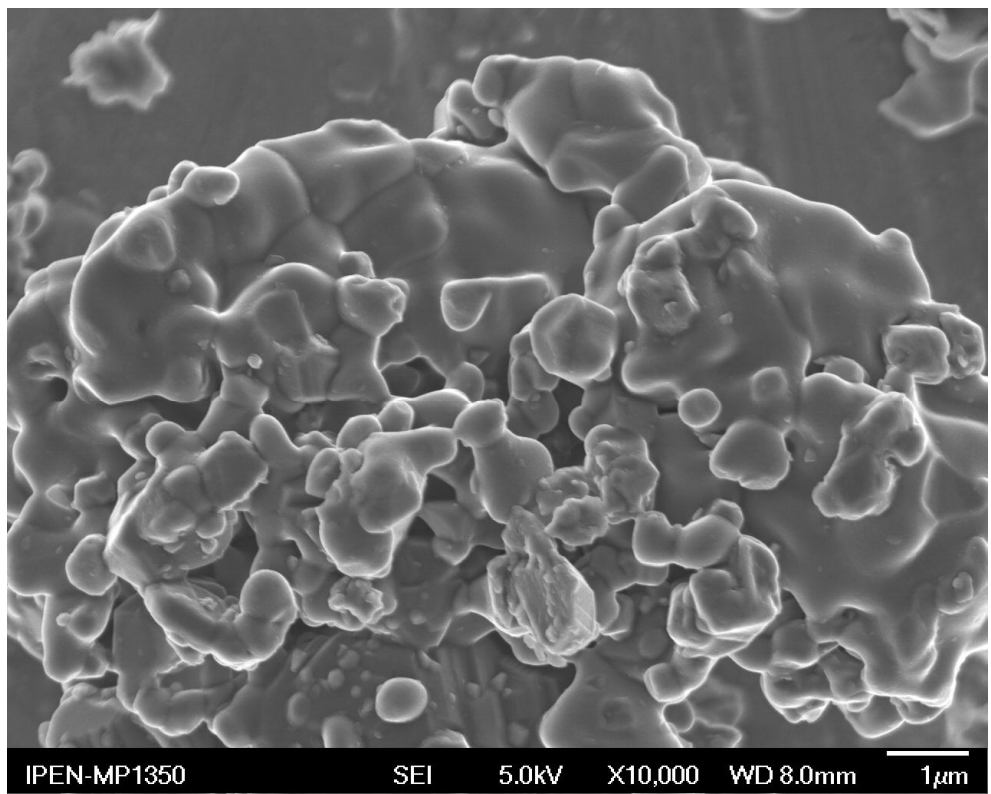

Figura 62 - Micrografia (MEV) do pó calcinado a $1350^{\circ} \mathrm{C}$ por 1 hora obtido pelo método de mistura de pós (MP)

$\mathrm{Na}$ micrografia da Fig. 63 observa-se que os aglomerados dos pós obtidos por coprecipitação após o tratamento térmico também são formados por grãos pequenos.

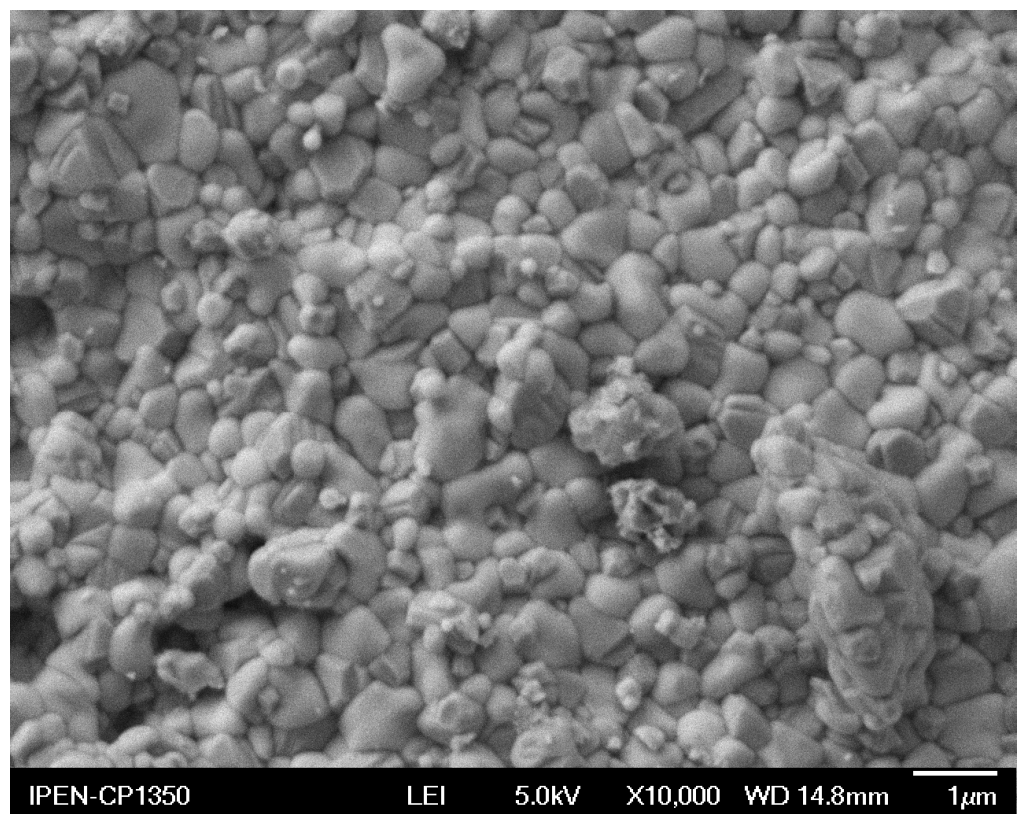

Figura 63 - Micrografia (MEV) do pó calcinado a $1350^{\circ} \mathrm{C}$ por 1 hora obtido pelo método de coprecipitação (CP)

Como podem ser observadas nas micrografias obtidas por microscopia eletrônica de varredura dos pós obtidos pelo método da coprecipitação, 
combustão e mistura de pós (Fig. 64, Fig. 65 e Fig. 66) as partículas encontram-se na forma de aglomerados com tamanho micrométrico. $O$ mapeamento por EDS (espectrômetro de dispersão de energia) nos aglomerados indica a presença das duas fases nos aglomerados, sendo que a distribuição mais homogênea das fases foi obtida por coprecipitação (Fig. 64).

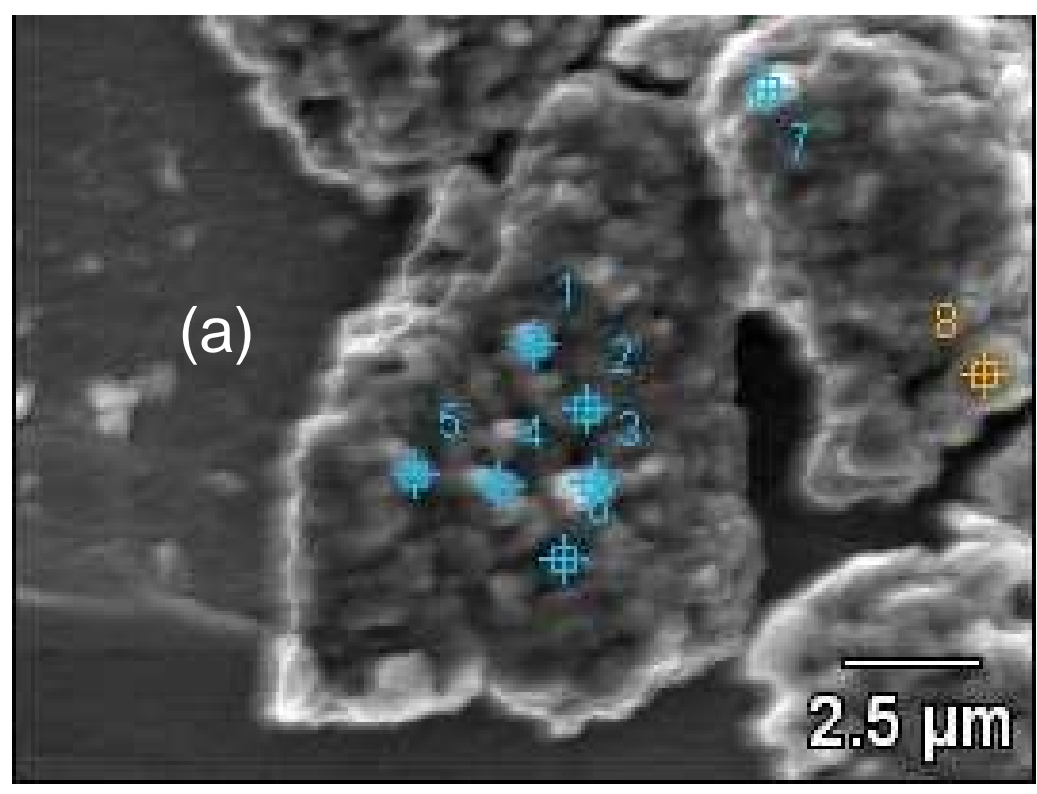

\begin{tabular}{ccc}
\hline Ponto & Ni-K & Zr-L \\
\hline \hline 1 & 43.78 & 56.22 \\
2 & 65,37 & 33.63 \\
3 & 52.50 & 47,50 \\
4 & 37,49 & 62,51 \\
5 & 72,41 & 27.59 \\
6 & 59.68 & 40,32 \\
7 & 48,86 & 51,14 \\
8 & 52,74 & 47,26 \\
\hline
\end{tabular}

Figura 64 - Micrografia (MEV) do pó calcinado a $1350{ }^{\circ} \mathrm{C}$ por 1 hora obtido pelo método da coprecipitação e mapeamento por EDS para identificação das fases no aglomerado. 


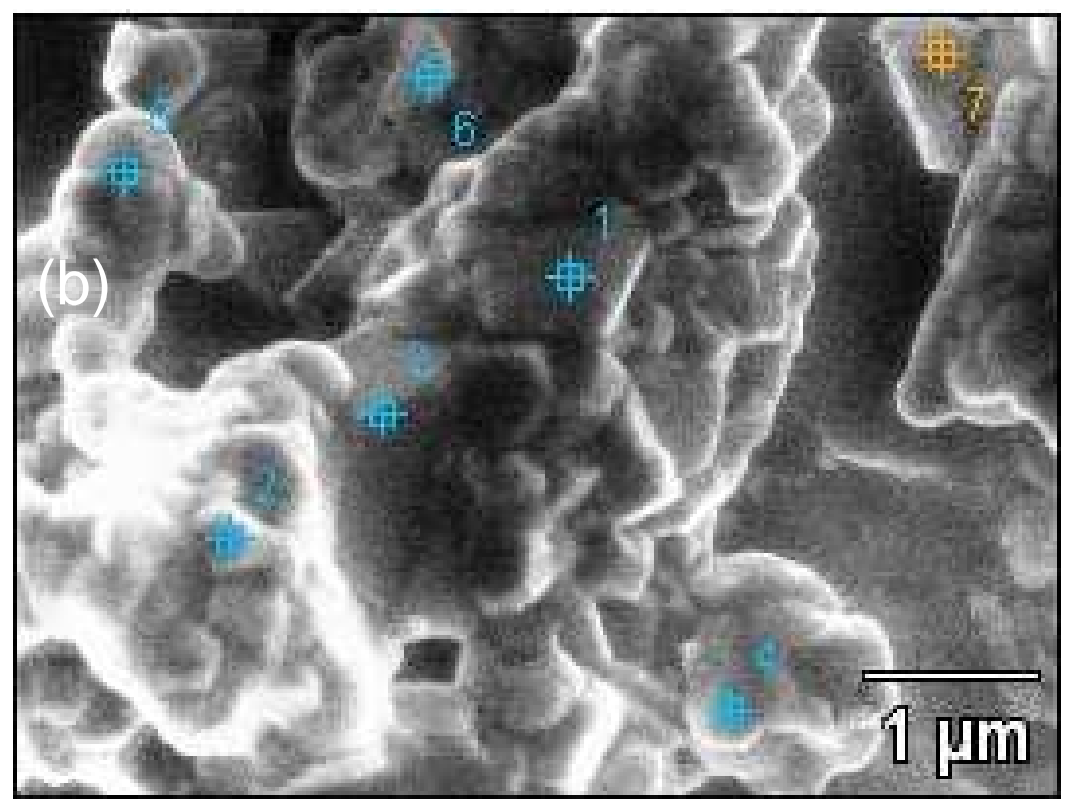

\begin{tabular}{ccc}
\hline Ponto & $\mathrm{Ni}-\mathrm{L}$ & $\mathrm{Zr}-\mathrm{L}$ \\
\hline 1 & 95,34 & 4,66 \\
2 & 87,25 & 12,75 \\
3 & 86,95 & 13,05 \\
4 & 90,99 & 9,01 \\
5 & 27,07 & 72,93 \\
6 & 11,33 & 88,67 \\
7 & --- & 100,00 \\
\hline
\end{tabular}

Figura 65 - Micrografia (MEV) do pó calcinado a $1350 \stackrel{\circ}{ } \mathrm{C}$ por 1 hora obtido pelo método da combustão e mapeamento por EDS para identificação das fases no aglomerado. 


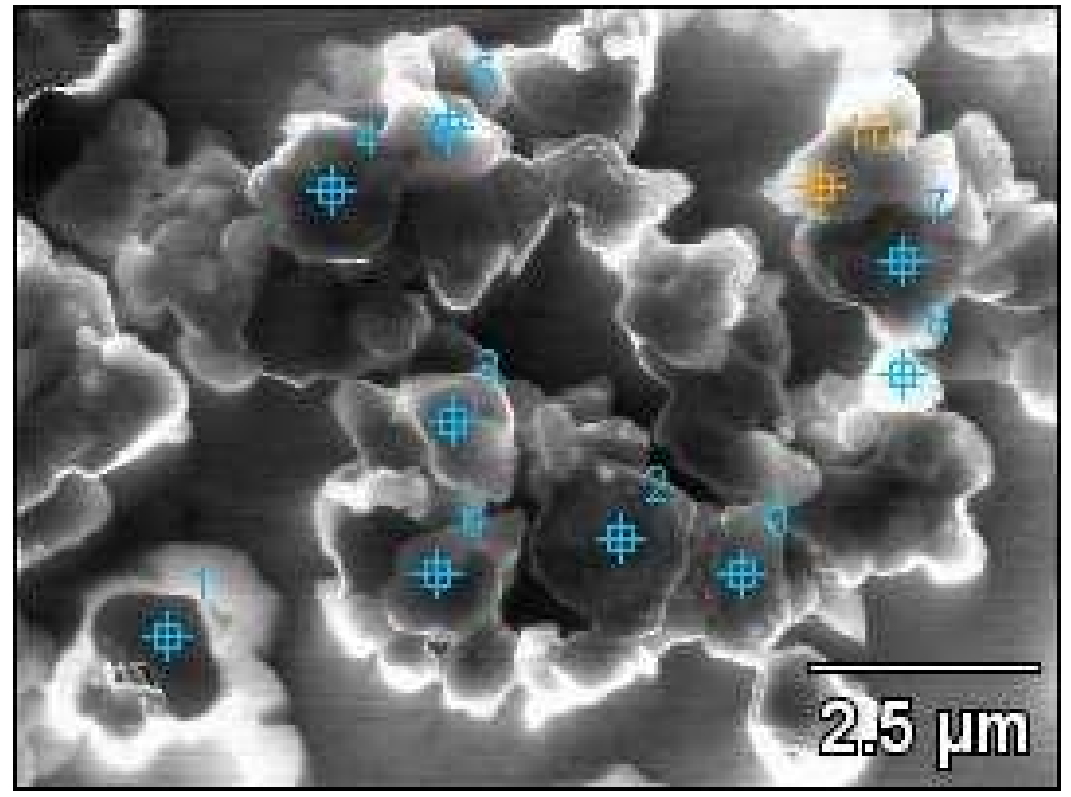

\begin{tabular}{ccc}
\hline \hline Ponto & Ni-K & Zr-L \\
\hline 1 & 26.37 & 73.63 \\
2 & 91.67 & 8.33 \\
3 & 7.47 & 92.53 \\
4 & 76.62 & 23.38 \\
5 & 15.46 & 84.54 \\
6 & 5.29 & 94.71 \\
7 & 83.82 & 16.18 \\
8 & 24.60 & 75.40 \\
9 & 90.45 & 9.55 \\
10 & 10.39 & 89.61
\end{tabular}

Figura 66 - Micrografia (MEV) do pó calcinado a $1350{ }^{\circ} \mathrm{C}$ por 1 hora obtido pelo método da mistura de pós e mapeamento por EDS para identificação das fases no aglomerado. 
Nas curvas apresentadas na Fig. 67 observa-se que o perfil da curva dos pós obtidos por combustão é praticamente linear até a fração de $80 \%$ de óxido de níquel reduzido em função da temperatura, enquanto nos outros dois métodos é observada uma alteração no coeficiente angular para fração de óxido de níquel reduzido acima de $65 \%$. Esta alteração no coeficiente angular está relacionada à maior dificuldade do gás redutor de atingir as áreas de $\mathrm{NiO}$, isto é a região da interface $\mathrm{NiO} / \mathrm{Ni}$ torna-se mais densa ou a trajetória da porosidade mais tortuosa, estes fatores dificultam a retirada das moléculas de água e consequentemente provoca o decréscimo na taxa de redução. Segundo Modena et. al. [121] a redução do NiO-YSZ obedece uma cinética linear e é controlado pela reação química na interface $\mathrm{NiO} / \mathrm{Ni}^{0}$.
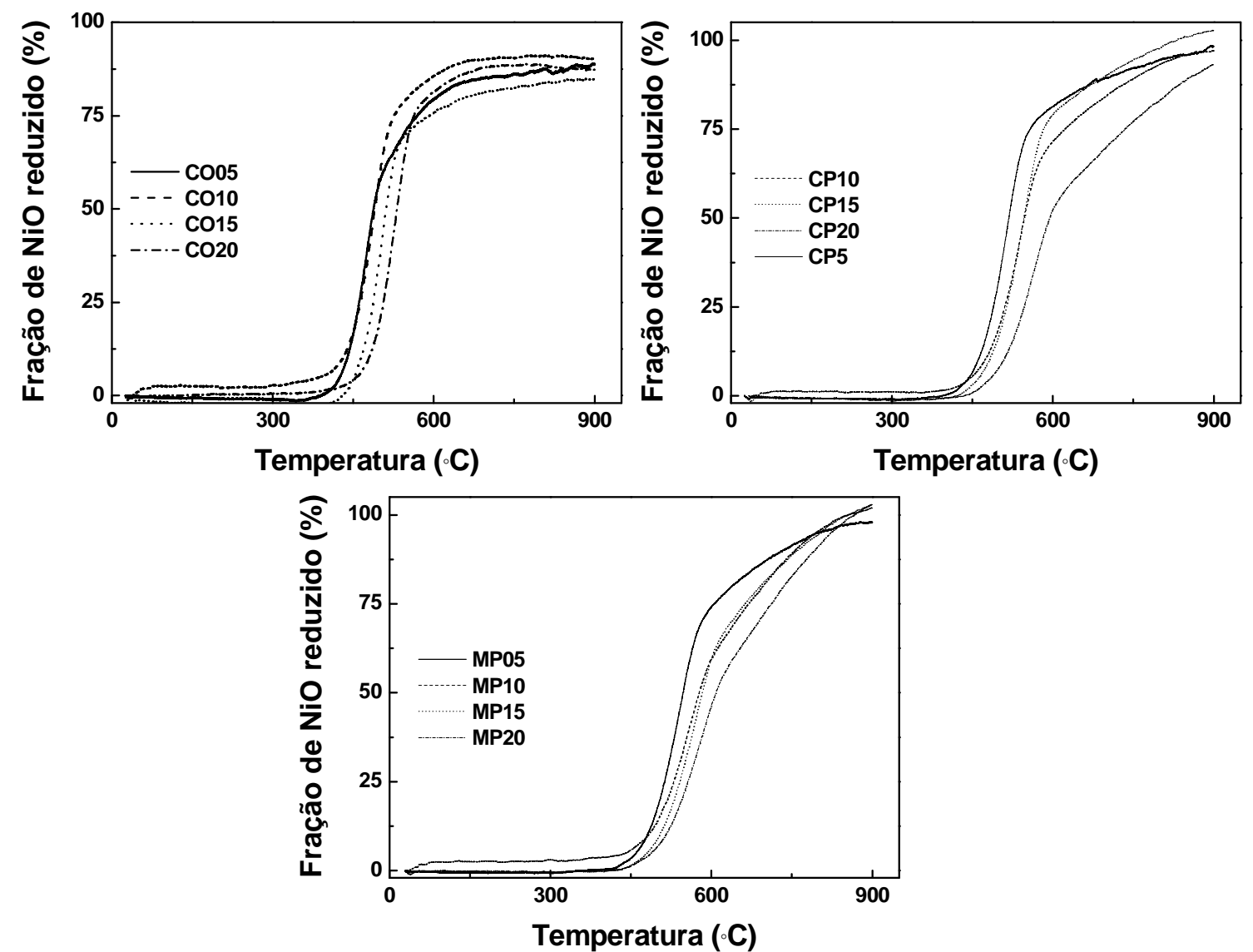

Figura 67- Taxa de redução em função da temperatura para amostras obtidas pelos três métodos de síntese submetidas a uma vazão de $100 \mathrm{~mL} \cdot \mathrm{min}^{-1} \mathrm{em}$ atmosfera dinâmica de $20 \%$ de $\mathrm{H}_{2}$ em balanço com Ar e diferentes taxa de aquecimentos $\left(5,10,15\right.$ e $\left.20 \stackrel{\circ}{\circ} \cdot \mathrm{min}^{-1}\right)$. 
Uma das condições desejáveis para que o compósito na forma de camada ou corpo cerâmico sinterizado seja utilizado como anodo é que a porosidade da amostra após a sinterização atinja valor entre 10 e 20 [23,97].

Na Fig.68 são apresentadas as curvas de perda de massa a $900{ }^{\circ} \mathrm{C}$ em função do tempo de redução de amostras cerâmicas NiO-YSZ obtidas a partir de pós sintetizados pelas três técnicas estudadas e sinterizadas a $1350{ }^{\circ} \mathrm{C}$ por 1 hora, para avaliar a porosidade introduzida após a redução nas cerâmicas sinterizadas sem a introdução de formadores de poros.

A partir da Fig. 69 observa-se que o comportamento das curvas em uma isoterma de $900^{\circ} \mathrm{C}$ apresenta uma cinética de reação de primeira ordem com dois estágios bem definidos. No primeiro estágio a cinética de redução é linear e muito rápida, enquanto no segundo estágio a de redução é mais lenta e diminui continuamente até que a velocidade de reação diminui drasticamente devido à formação de cristalito de níquel na superfície dos óxidos, tornando a superfície dos óxidos cada vez menos acessível e também dificultando a saída de moléculas de água da superfície dos grãos de óxido de níquel [113]. A fração de NiO reduzido (Fig.67.b) atingiu valores próximos a 80\%.
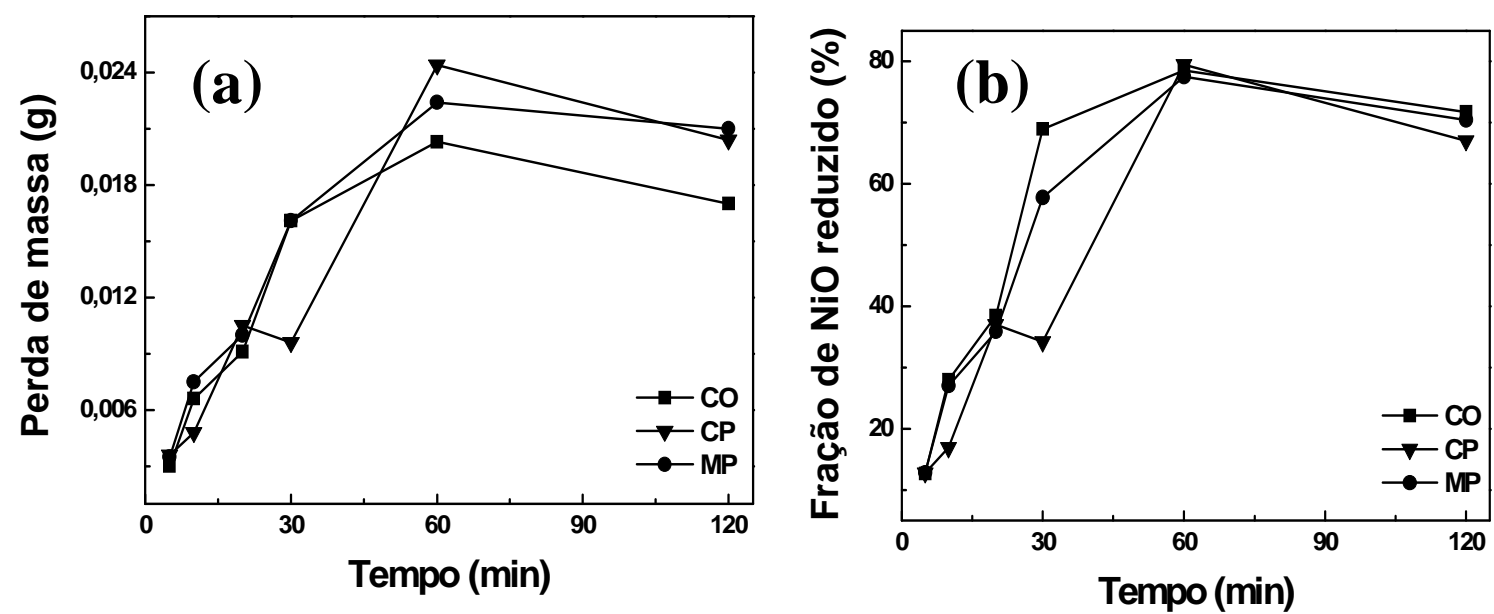

Figura 68- Curvas de perda de massa das amostras cerâmica NiO-YSZ obtidas em forno tubular a partir de pós sintetizados pelas técnicas (MP), (CP) e (CO), em função do tempo de redução em atmosfera dinâmica de $4 \% \mathrm{H}_{2}$ em balanço com Ar e vazão de $100 \mathrm{~mL} \cdot \mathrm{min}^{-1}$. 
Na Fig.69 são apresentadas as curvas de porosidade das amostras NiOYSZ após a redução, determinadas de acordo com ASTM C20-00, em função da fração de $\mathrm{NiO}$ reduzido. A porosidade introduzida após a redução oscilou entre $14,6 \%$ e $18 \%$, para tempo de 120 minutos, valor considerado muito abaixo do aceitável, que é acima de 30\% para um bom desempenho do anodo. Neste caso, o procedimento normalmente adotado para aumentar a porosidade consiste em adicionar, na composição inicial, um formador de poros tais como grafite, amidos e polímeros orgânicos. Assim, a forma e tamanho dos poros são influenciados pelo tamanho, forma e quantidade de formador de poros, que conseqüentemente irão influenciar na eficiência do anodo.

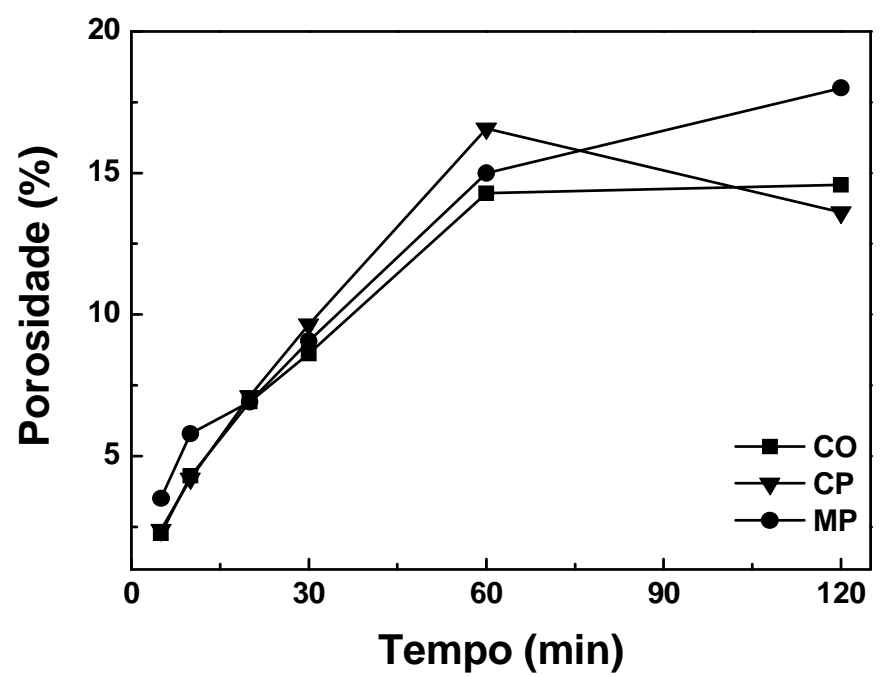

Figura 69- Curvas de porosidade em função do tempo para amostras $\mathrm{CO}, \mathrm{CP}$ e MP, submetidas à redução em isoterma de $900^{\circ} \mathrm{C}$ por período entre 05 e 120 minutos

Neste trabalho foram utilizados três tipos de formadores de poros (amido de milho, farinha de jatobá e negro de fumo). A escolha destes formadores de poros, com diferentes valores de tamanho médio de partículas e morfologia, teve como objetivo avaliar a forma de poros e sua distribuição no corpo cerâmico bem como o efeito da porosidade na redução. A Fig. 70 mostra a forma e tamanho de aglomerados dos formadores de poros.

As micrografias na Fig. 71 mostram que o tamanho e forma dos poros introduzidos nas amostras mantêm certa semelhança tanto na morfologia como nas proporções do volume do formador de poros utilizado em cada amostra. 

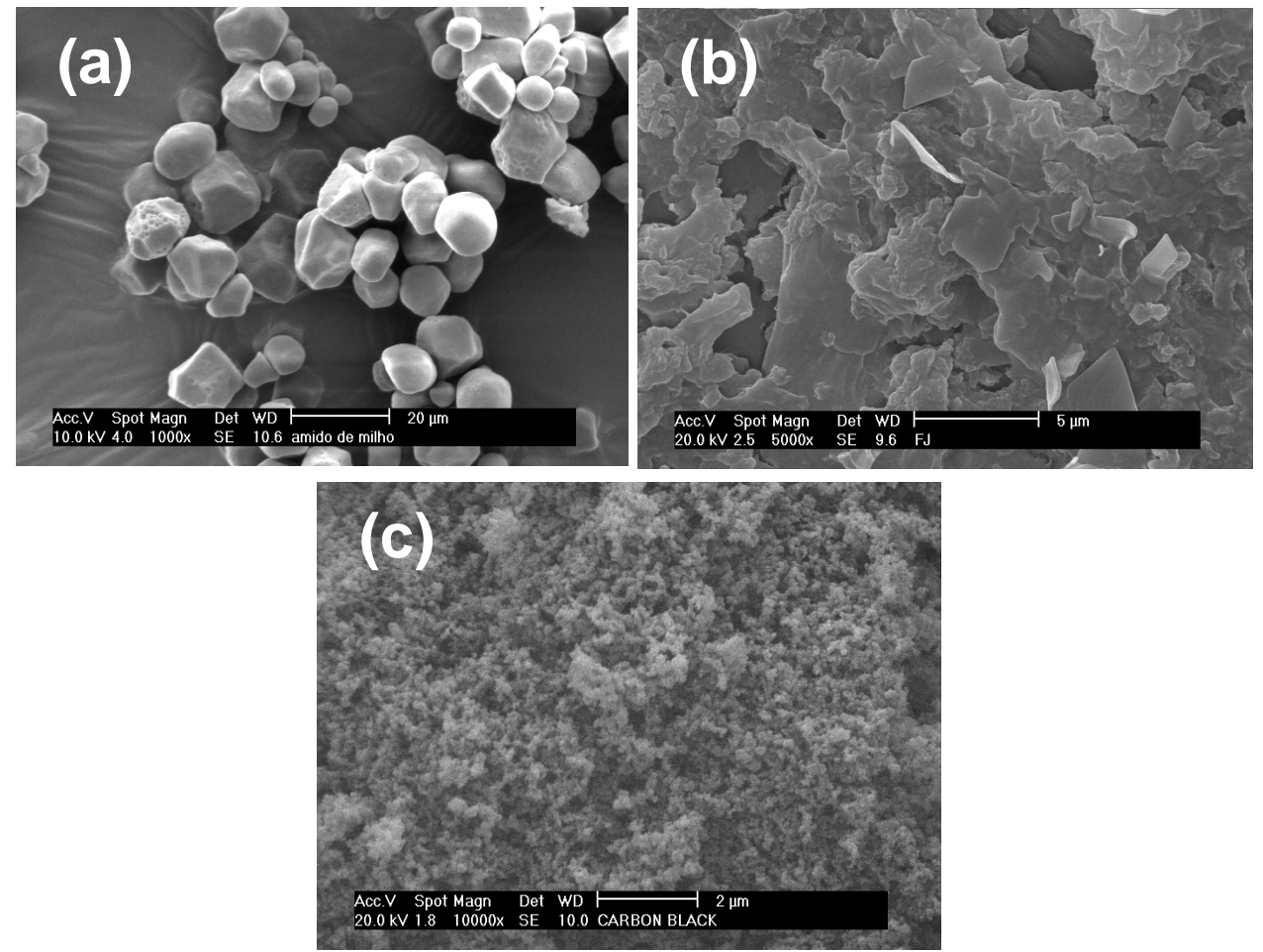

Figura 70 - Micrografias MEV dos formadores de poros: amido de milho (a), farinha de jatobá (b) e negro de fumo (c).
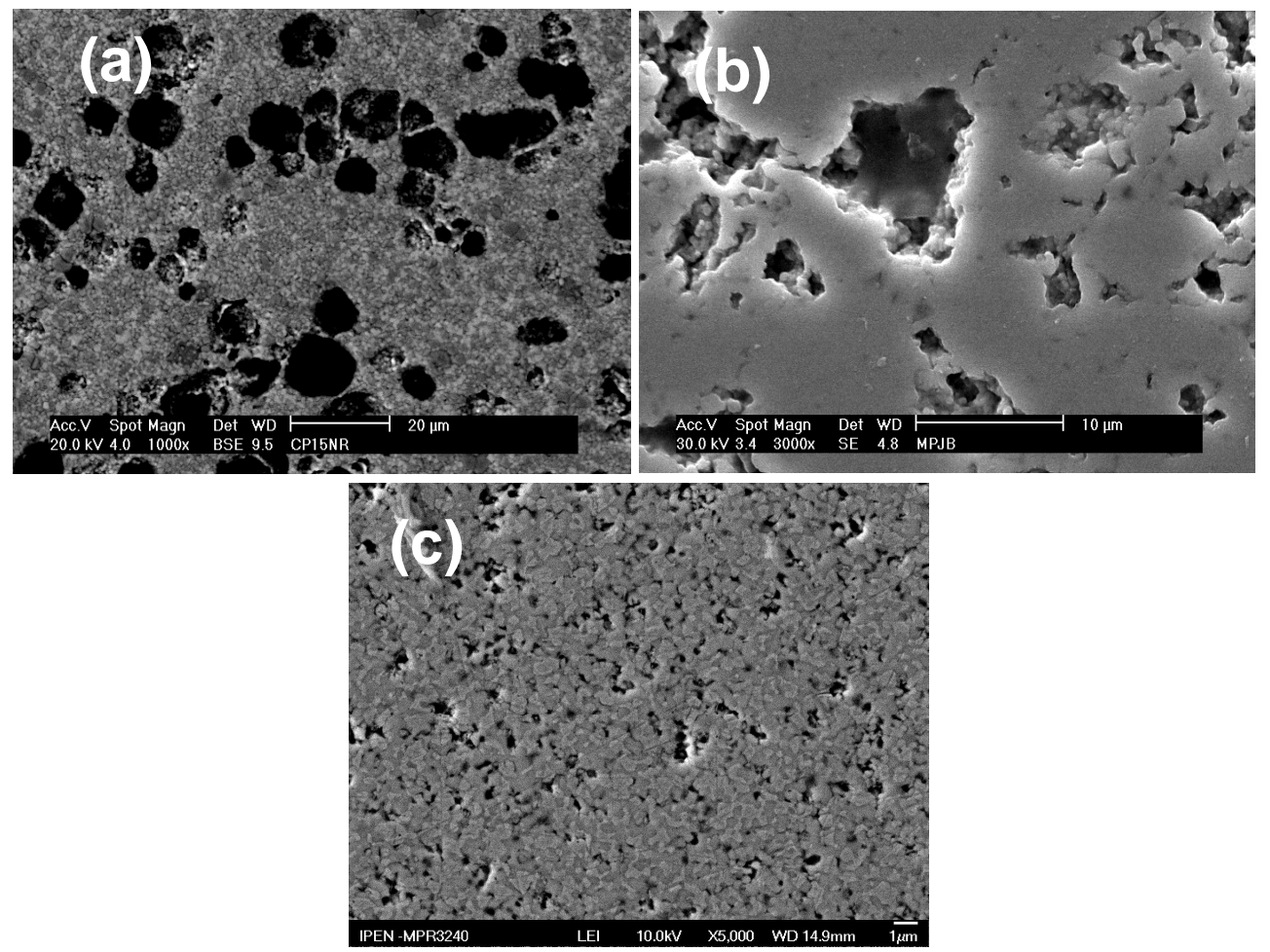

Figura 71 - Micrografias MEV das superfícies polidas e tratadas termicamente das amostras cerâmicas NiO-YSZ com formador de poros de amido de milho (a), farinha de jatobá (b) e negro de fumo (c). 
Para aumentar a porosidade, iniciou-se um estudo preliminar do uso de formador de poros, no caso amido de milho, em amostras obtidas pela técnica de coprecipitação.

Na Fig. 72 são apresentadas as curvas de perda de massa (\%) (Fig. 72.a) e DTG (Fig. 72.b) das amostras do corpo cerâmico obtidos com, respectivamente, 10, 15 e $20 \%$ de amido de milho.

Para o cálculo da taxa de redução foi considerada a porção inicial da curva de redução da Fig. 72.b. Uma linha tangente é associada com esta região linear e o valor, em mg.min ${ }^{-1}$, é determinado. A amostra com $20 \%$ de formador de poros apresentou uma taxa de redução de 2,24 mg.min ${ }^{-1}$, enquanto as amostras com 10 e $15 \%$ de formador de poros apresentaram praticamente a mesma taxa de redução, isto é, 1,64 e $1,61 \mathrm{mg} \cdot \mathrm{min}^{-1}$ respectivamente.

$\mathrm{Na}$ Fig. 72.c são mostradas as curvas de fração de $\mathrm{NiO}$ reduzido em função do tempo para os corpos cerâmicos contendo 10, 15 e 20\% de amido de milho. Observa-se que o comportamento de redução das amostras CP 15 e CP 20 são semelhantes, sendo a fração de redução elevada no início do processo é lenta em função do tempo.
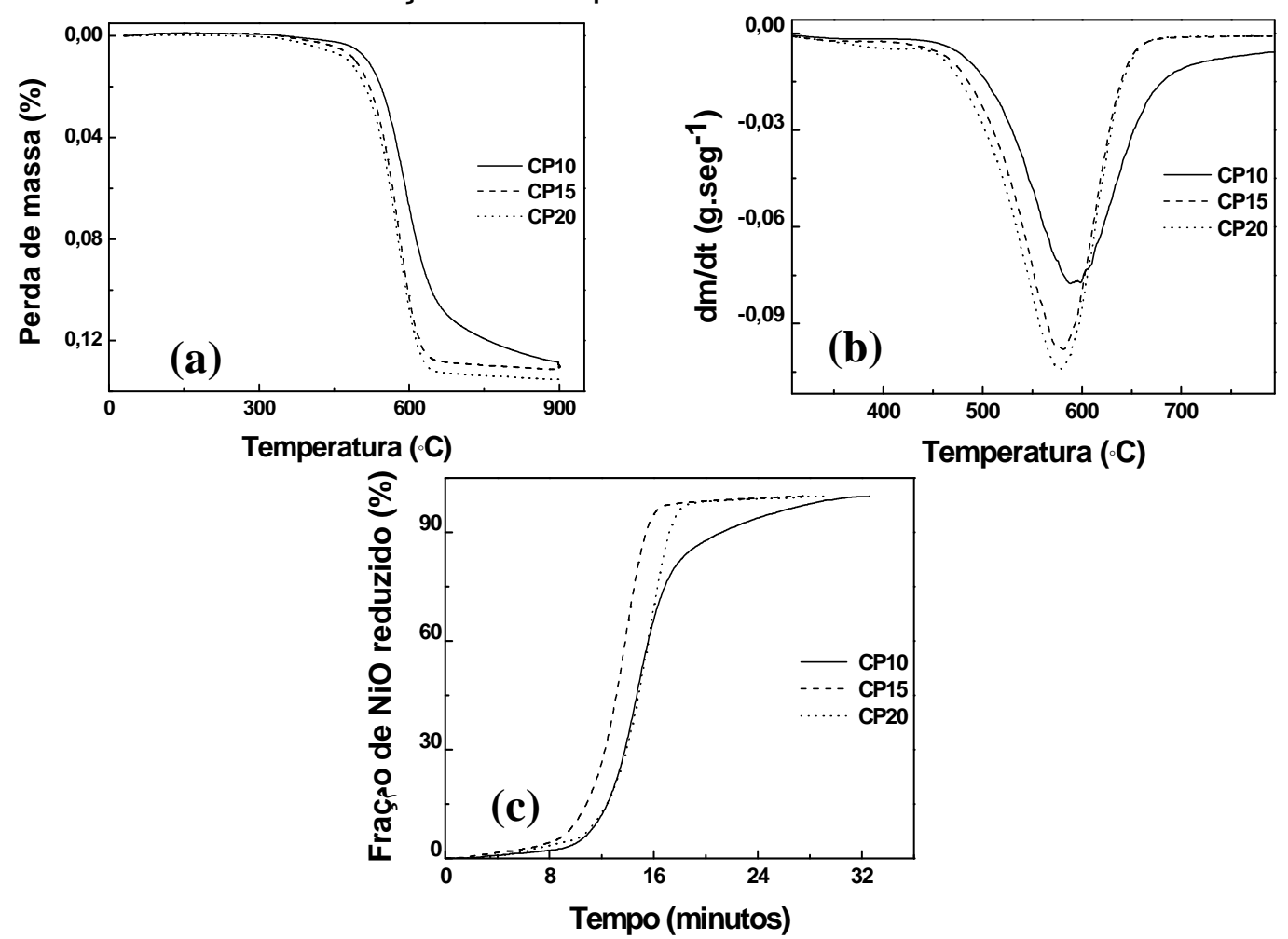

Figura 72 - Perda de massa (a) e taxa de redução em função da temperatura (b) para amostras com 10, 15 e 20\% de amido de milho e fração de $\mathrm{NiO}$ reduzido em função do tempo 
Esta diferença na taxa de redução está relacionada com a maior área superficial para ocorrer a reação, isto é, superfície externa e poros abertos, em contato com o gás redutor. Além da maior área de contato, a alta porosidade favorece a difusão do gás hidrogênio e sendo provavelmente necessária uma menor profundidade de difusão. Desta forma, a redução do $\mathrm{NiO}$ com 0 hidrogênio é extremamente rápida, resultando em um menor tempo de redução.

$\mathrm{Na}$ Tab. 27 são apresentadas as densidades relativas e porosidades das amostras CP com formador de poros sinterizadas em ar atmosférico antes da redução.

Tabela 27 - Valores de densidades e porosidades das amostras cerâmicas de NiO-YSZ provenientes de pós sintetizados por coprecipitação, sinterizadas com a presença de formador de poros

\begin{tabular}{cccc}
\hline \hline \multicolumn{2}{c}{ Formador de poros } & \multicolumn{2}{c}{ Amido de milho } \\
\hline \hline Amostra & $\rho_{\mathrm{h}}\left(\mathrm{g} . \mathrm{cm}^{-3}\right)$ & $\rho_{\text {relativa }}(\%)$ & Porosidade (\%) \\
\hline CP10 & 5,53 & 83,4 & 6,92 \\
CP15 & 5,11 & 77,1 & 20,21 \\
CP20 & 4,78 & 72,1 & 26,46 \\
\hline \hline
\end{tabular}

$\mathrm{Na}$ Tab. 28 são apresentados os valores de densidade relativa e porosidade das amostras após a redução. O aumento na porosidade das amostras em relação às amostras sinterizadas foi de aproximadamente $17 \%$. Em toda faixa de concentração de formador de poros estudada a porosidade introduzida ficou dentro do limite considerado adequado para percolação dos gases na cerâmica. 
Tabela 28 - Densidades das amostras com formadores de poros (amido de milho) submetidos à redução em atmosfera de hidrogênio

\begin{tabular}{cccc}
\hline \multicolumn{2}{c}{ Formador de poros } & \multicolumn{2}{c}{ Amido de milho } \\
\hline \hline Amostra & $\rho_{\mathrm{h}}\left(\mathrm{g} \cdot \mathrm{cm}^{-3}\right)$ & $\rho_{\text {relativa }}(\%)$ & Porosidade (\%) \\
\hline CP10 & 4,83 & 71,8 & 30,4 \\
CP15 & 4,43 & 67,3 & 37,9 \\
CP20 & 4,08 & 66,8 & 41,4 \\
\hline \hline
\end{tabular}

No estudo da porosidade com farinha de jatobá como formador de poros o objetivo foi avaliar a porosidade introduzida com material com formato lamelar e não homogêneo. Os resultados apresentados na Fig.73 referem-se às amostras $\mathrm{CO}, \mathrm{CP}$ e MP que foram submetidas a uma atmosfera redutora de $4 \% \mathrm{H}_{2}$ em balanço com $\mathrm{Ar}$ a $900^{\circ} \mathrm{C}$ com diferentes concentraç ões de formadores de poros (farinha de jatobá). A redução das amostras foi realizada em forno tubular com atmosfera controlada.

A porosidade introduzida para uma concentração de $20 \%$ em massa de formador de poro foi insuficiente para atingir o valor de porosidade considerado adequado para percolação dos poros para amostras CP (22,6\%). Na amostra MP e CO a porosidade introduzida foi de $30,5 \%$ e $33,4 \%$ respectivamente, estes valores são considerados praticamente dentro da especificação para uma boa difusão dos gases. 


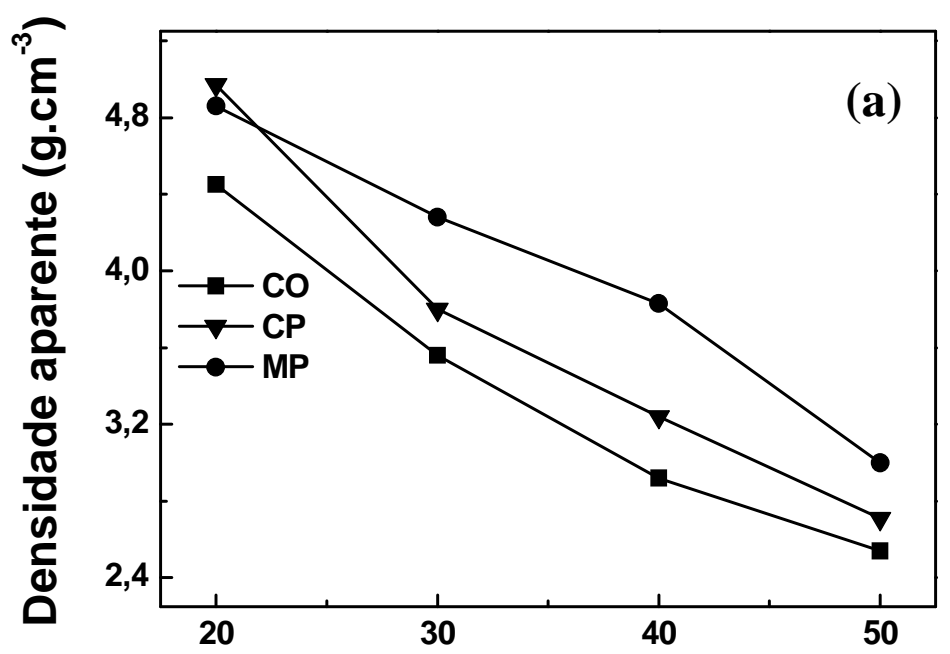

Formador de poros (\% em massa)

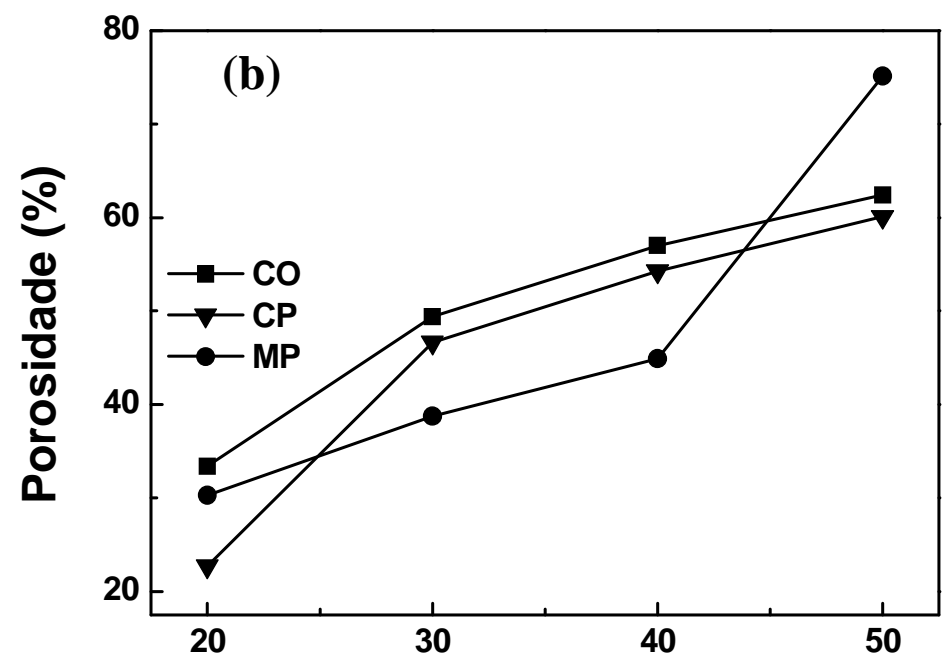

Formador de poros (\% em massa)

Figura 73 - Valor de densidade aparente (a) e de porosidade em função da temperatura (b) para amostras $\mathrm{CO}, \mathrm{CP}$ e MP reduzidas em forno tipo caixa a $900^{\circ} \mathrm{C}$ sob atmosfera dinâmica de $\mathrm{H}_{2}$

$\mathrm{Na}$ Tab. 29 estão apresentados os valores de densidade relativa e porosidade obtidos para amostras com $30 \%$ de formador de poros (farinha de jatobá), antes da redução.

A porosidade inicial da amostra MP-30 apesar de estar um pouco acima da especificação ainda é considerada adequada para uma percolação dos poros após a redução. Em relação às amostras CO-30 e CP-30 a porosidade está muito acima da especificação. 
Tabela 29 - Densidades e porosidades das amostras com formadores de poros (farinha de jatobá) antes da redução.

\begin{tabular}{cccc}
\hline \hline Amostra & $\rho_{\mathrm{h}}\left(\mathrm{g} \mathrm{cm}^{-3}\right)$ & $\rho_{\text {relativa }}(\%)$ & Porosidade $(\%)$ \\
\hline \hline CO-30 & 3,57 & 56,3 & 41,61 \\
CP-30 & 4,33 & 68,3 & 30,63 \\
MP-30 & 4,82 & 76,0 & 23,55 \\
\hline \hline
\end{tabular}

$\mathrm{Na}$ Tab. 30 são apresentados os valores de densidade relativa e porosidade para amostras com 30\% de formador de poros. A amostra MP-30 apresentou após a redução uma porosidade final dentro especificação.

Tabela 30 - Densidades e porosidades das amostras com formadores de poros (farinha de jatobá) após a redução.

\begin{tabular}{cccc}
\hline Amostra & $\rho_{\mathrm{h}}\left(\mathrm{g} \cdot \mathrm{cm}^{-3}\right)$ & $\rho_{\text {relativa }}(\%)$ & $\mathrm{P}(\%)$ \\
\hline CO-30 & 2,92 & 46,0 & 49,4 \\
CP-30 & 3,82 & 59,3 & 46,7 \\
MP-30 & 4,27 & 66,3 & 38,0 \\
\hline \hline
\end{tabular}

Conclui-se que para as amostras CO e MP a adição de $20 \%$ de farinha de jatobá é suficiente para atingir a porosidade necessária para percolação dos gases, já no caso da amostra CP a adição de formador de poros deve ficar no intervalo entre $20 \%$ e $30 \%$.

A microestrutura do compósito com formador de poros de farinha de jatobá é apresentada na Fig. 74. Observa-se a formação de poros grandes e pequenos, com morfologia não homogênea e sem uma orientação definida na microestrutura. 


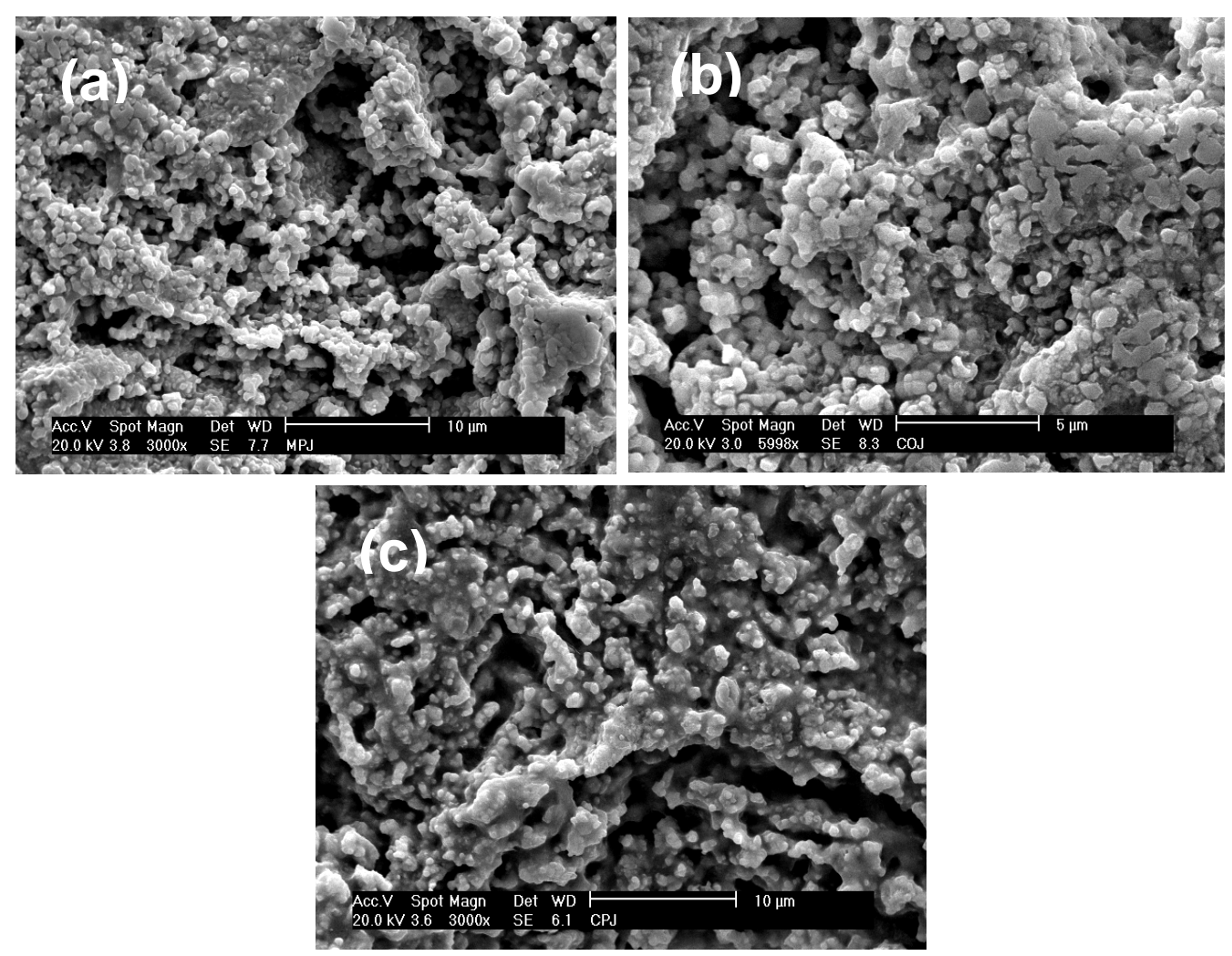

Figura 74 - Micrografias (MEV) das superfícies de fratura das amostras cerâmicas com formadores de poros de farinha jatobá obtidas pelos três métodos (mistura mecânica de pós (a), combustão (b) e coprecipitação (c)) por prensagem uniaxial e sinterização a $1350^{\circ} \mathrm{C}$ por 1 hora

Segundo a literatura a adição de formadores de poros mesmo em pequena quantidade favorece uma menor polarização e consequentemente uma maior densidade de potência. Mesmo a adição de volume relativamente pequeno de poros grandes favorece a difusão dos gases diminuindo a polarização no anodo e, consequentemente, aumento do desempenho da célula, mesmo sem um aumento substancial da porosidade total. Esta porosidade adicional pode aumentar a quantidade de sitos ativos e com isso a eficiência da atividade eletroquímica aumenta. No entanto, existe uma quantidade ideal de porosidade acrescentada, pois um excesso de poros pode provocar a substituição dos sítios ativos por poros na interface e com isso o desempenho da célula diminui [122]. 
Uma avaliação preliminar em função dos poros introduzidos nas amostras sinterizadas para os dois tipos de formadores de poros estudado acima indica que o material compósito nestas condições é mais adequado para aplicação como material suporte da célula devido às dimensões dos poros.

A opção pelo uso de negro de fumo como uma alternativa de formador de poros foi em função do tamanho namométrico dos pós. Para este estudo foi adotado a concentração em massa de $30 \%$ em relação à massa de óxido de níquel e os resultados são apresentados na Figura 75. A fração de $\mathrm{NiO}$ reduzida atinge valores acima de $95 \%$ para os três métodos de síntese e a porosidade introduzida ficou dentro do valor considerado aceitável para uso como anodo.
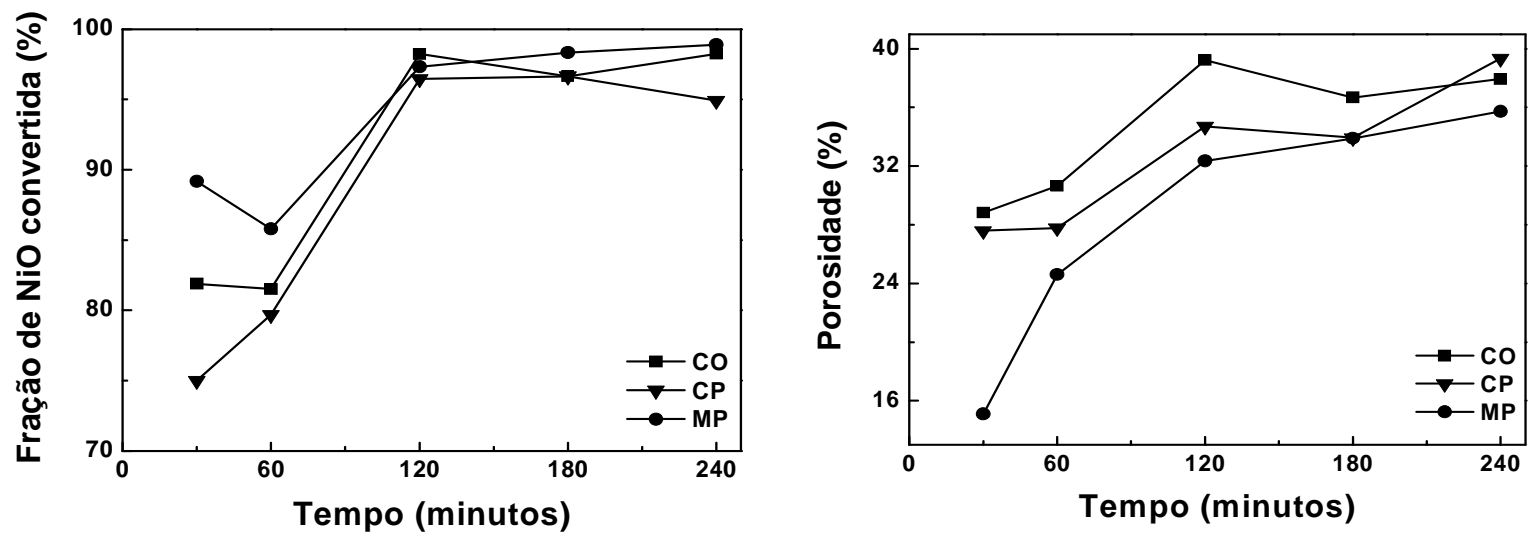

Figura 75 - Fração de $\mathrm{NiO}$ reduzido em função do tempo nas amostras cerâmicas obtidas pelos métodos de combustão (CO), coprecipitação (CP) e mistura de pós (MP) com formador de poros de negro de fumo.

Na Tab.31 são apresentadas as densidades relativas e porosidade das amostras com formador de poros, sinterizadas em ar atmosférico e na Tab.32, os valores de densidade aparente e porosidade introduzida após a redução. 
Tabela 31 - Densidade hidrostática e relativa e porosidades das amostras com formadores de poros (negro de fumo) antes da redução

\begin{tabular}{cccc}
\hline \hline amostra & $\rho_{\mathrm{h}}\left(\mathrm{g} \cdot \mathrm{cm}^{-3}\right)$ & $\rho_{\text {relativa }}(\%)$ & $\mathrm{P}(\%)$ \\
\hline \hline CO-30 & 5,29 & 83,4 & 16,34 \\
CP-30 & 5,35 & 84,4 & 18,35 \\
MP-30 & 4,78 & 75,4 & 24,46 \\
\hline \hline
\end{tabular}

Tabela 32 - Densidade hidrostática e relativa e porosidades das amostras com formadores de poros (negro de fumo) após a redução

\begin{tabular}{cccc}
\hline amostra & $\rho_{\mathrm{h}}\left(\mathrm{g} \cdot \mathrm{cm}^{-3}\right)$ & $\rho_{\text {relativa }}(\%)$ & $\mathrm{P}(\%)$ \\
\hline CO-30 & 4,67 & 73,6 & 32,35 \\
CP-30 & 4,73 & 74,6 & 34,69 \\
MP-30 & 4,23 & 66,7 & 39,22 \\
\hline \hline
\end{tabular}

Na Fig. 76 observa-se que os poros introduzidos pelo formador de poros negro de fumo são uniformemente distribuídos tanto no tamanho como na distribuição dos poros. Apesar do tamanho nanométrico do formador de poros a porosidade introduzida foi eficiente na percolação do gás redutor fato comprovado pelo alto valor de conversão do óxido de níquel para níquel metálico e a porosidade obtida após a etapa de redução é considerada adequadas para formação de percolação dos poros e difusão dos gases em uma célula. 

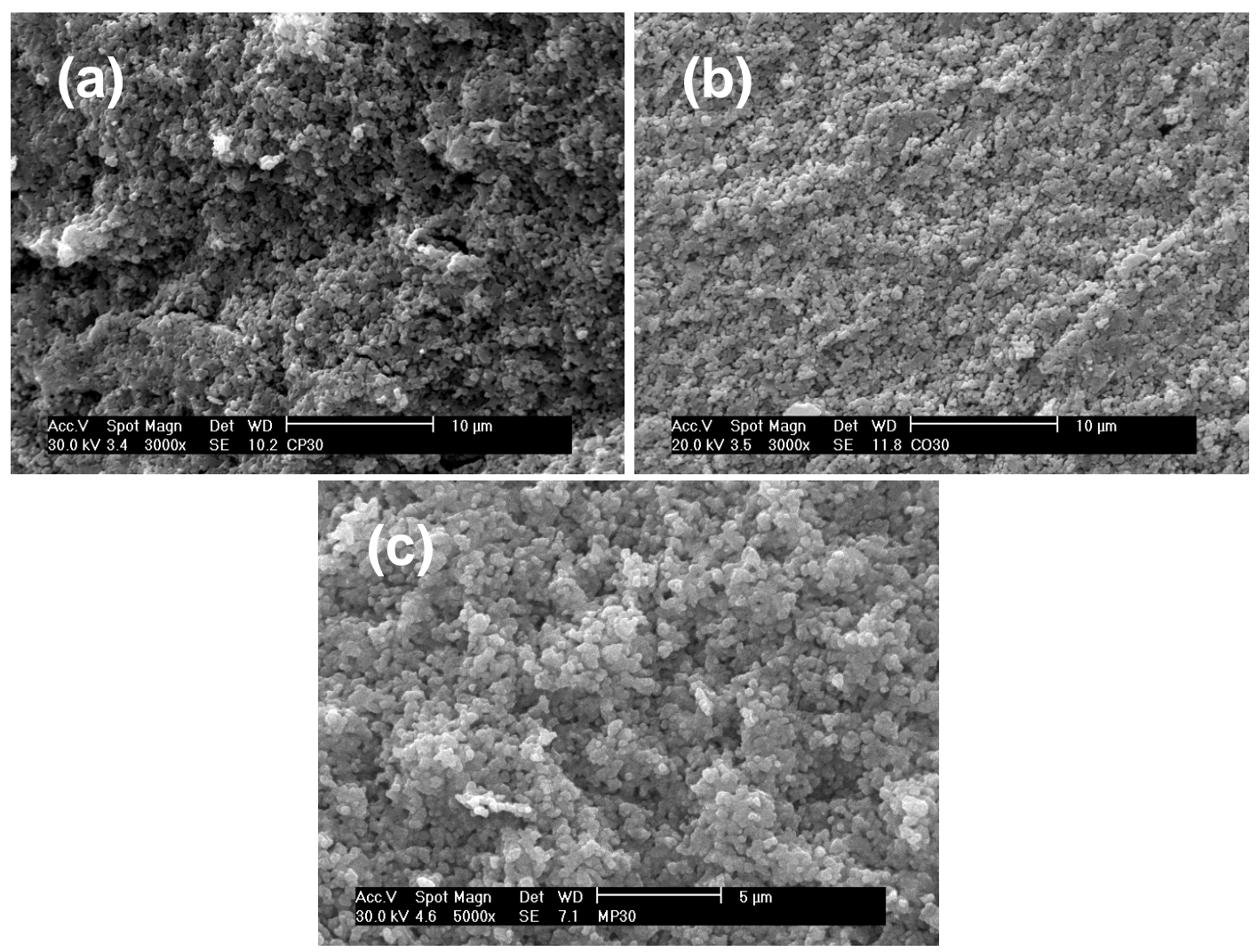

Figura 76 - Micrografias (MEV) das superfícies de fratura das amostras cerâmicas com formadores de poros de negro de fumo obtidas pelos três métodos (mistura mecânica de pós (a), combustão (b) e coprecipitação (c)) por prensagem uniaxial e sinterização a $1350{ }^{\circ} \mathrm{C}$ por 1 hora 


\section{CONCLUSÕES}

Considerando-se os resultados obtidos pode-se concluir que os três métodos de obtenção de pós são adequados para preparação de compósitos NiO-YSZ, desde que sejam adotadas condições otimizadas de síntese.

A síntese pela coprecipitação é um processo viável controlando-se rigorosamente a adição do agente precipitante e temperatura do meio onde ocorre a precipitação. $O$ rendimento de precipitação pode ser otimizado pelo controle do pH em torno de 9,5 mantendo-se a concentração de cátions níquel no meio precipitante em $0,1 \mathrm{M}$ e temperatura da solução a ser precipitada em $98^{\circ} \mathrm{C}$.

No caso da rota de mistura de pós os resultados demonstram que em suspensões contendo $0,8 \%$ de dispersante e pH entre 8 e 9 é possível obter uma mistura homogênea dos pós devido à não sedimentação diferencial dos pós NiO e YSZ.

Em relação ao método de síntese de pós por combustão, os estudos têm demonstrado que em função da relação sal de nitrato/uréia é possível obter pós com uma larga faixa de área de superfície, morfologia e cristalinidade. Quanto maior o excesso de combustível menor a área de superfície específica e mais cristalinos são os pós. No estudo de calcinação das amostras obtidas com adição estequiométrica de combustível, conclui-se que quanto maior a temperatura de calcinação maior a porosidade das amostras.

No estudo de sinterabilidade de cerâmicas de NiO-YSZ pelo método não isotérmico os três métodos de síntese apresentam em comum a temperatura ao redor de $1300^{\circ} \mathrm{C}$ para máxima taxa de densificação. As energias de ativação de densificação das amostras apresentaram valores muito próximos nos modelos empíricos adotados, com exceção das amostras MP que apresentou uma energia de ativação maior pelo método quase-isotermico. A porosidade nas amostras sinterizadas à $1300^{\circ} \mathrm{C}$ em forno tipo c aixa ficaram entre 6 e $13 \%$ indicando a necessidade de utilizar formadores de poros. A distribuição das fases cerâmica e metálica entre os métodos estudados é praticamente idêntica e apresenta uma distribuição bem homogênea das fases. 
O estudo da cinética de redução em condição não isotérmica dos pós submetidos a tratamento térmico a $1350 \stackrel{\circ}{\circ}$ por 1 hora indicam que a redução do óxido de níquel começa a ocorrer acima de $420 \stackrel{\circ}{\circ}$ para os três métodos de síntese. Para uma taxa de aquecimento de $10{ }^{\circ} \mathrm{C} \cdot \mathrm{min}^{-1}$ a maior taxa de redução ocorre em pós obtidos por combustão $\left(0,134 \mathrm{mg} \cdot \mathrm{min}^{-1}\right)$ e a menor para pós obtidos por mistura de pós $\left(0,081 \mathrm{mg}\right.$. $\left.\mathrm{min}^{-1}\right)$. Os altos valores de energia de ativação obtidos para os pós de coprecipitação e mistura de pós $(143,21$ e $141,89 \mathrm{k} \cdot \mathrm{J} \cdot \mathrm{mol}^{-1}$, respectivamente) estão provavelmente relacionados, no caso da coprecipitação à maior interação entre o óxido de níquel e o suporte zircônia e ao crescimento dos grãos, e no caso da mistura de pós, o valor da energia de ativação está relacionado ao crescimento dos grãos. O menor valor de energia de ativação dos pós obtidos por combustão $\left(74,59{\left.\mathrm{k} \mathrm{J} . ~ \mathrm{~mol}^{-1}\right)}^{-1}\right.$ está relacionado ao menor tamanho de grãos nos aglomerados.

No processo de redução à temperatura de $900^{\circ} \mathrm{C}$, para os corpos cerâmicos obtidos pelos três métodos de síntese, o mecanismo de redução apresenta uma cinética de primeira ordem com dois estágios bem definidos para todas as amostras. A fração de $\mathrm{NiO}$ reduzido atingiu valores próximos a $80 \%$ e uma porosidade entre 14,6 e $18 \%$.

Nos estudos com formadores de poros, a amostra obtida por coprecipitação com $15 \%$ de amido de milho apresentou uma porosidade adequada, indicando uma melhor difusão do gás hidrogênio e saída dos vapores de água. A porosidade introduzida pela farinha de jatobá com concentração de $20 \%$ em massa ficou dentro da especificação para amostras obtidas por mistura de pós e combustão e um pouco abaixo para amostras por coprecipitação. A distribuição mais homogênea tanto na distribuição como morfologia dos poros foram obtidas com negro de fumo como formador de poros. Para uma concentração de $30 \%$ em massa a porosidade das amostras ficaram entre 32 e $39 \%$ e a fração de $\mathrm{NiO}$ reduzido acima de $98 \%$. 


\section{VII - SUGESTÕES PARA TRABALHOS FUTUROS}

- Preparar uma semi célula utilizando o compósito como substrato e também como anodo. A deposição do compósito como camada funcional anodo e o eletrólito YSZ será pela técnica de aspersão de tintas.

- Com base na teoria de microscopia quantitativa fazer um estudo da continuidade das fases metálica, cerâmica e poros utilizando um analisador de imagem.

- Com a definição das condições otimizadas fazer a caracterização das propriedades elétricas e eletroquímicas de Ni-YSZ.

- Estudo do compósito para aplicação como catalisador. 


\section{VIII - REFERÊNCIAS BIBLIOGRÁFICAS}

1. Antonucci, V., Antonucci, P.L., Gullo, L., LaRosa, D., Siracusano, S. Advanced (electro) ceramics and innovative energy Technologies. J. Eur. Ceram. Soc., v. 24, p. 1337 - 1342, 2004.

2. Grove, W.R., Philos. Mag., v. 14, p. $127-130,1839$, apud Omerod, R. M. Solid oxide fuel cell. Chem Soc Rev., v. 32, p. 32, 7-28, 2003.

3. Nernst, W. Z. Electrochem., 1899, 6, 41 - 43 apud Kakaç, S: Pramuanjaroenkij, A; Zhou, X.Y. A Review of numerical modeling of solid oxide fuel cell. Int. J. Hydrogen Energy, v. 32, p. 761 - 786, 2006.

4. Baur, E; Preis, H..Z.; Electrochem. 1937; 43: 727 - 732 apud Stambouli, A. B., Traversa, E., Solid oxide fuel cells (SOFCs): a review of an environmentally clean and efficient source of energy. Renew. Sust. Energy Rev., v. 6, p. 433-455, 2002.

5. Yasuzo T., Progress in Fuel Cell Technologies. I.E.E. J. Trans. F.M., v.12, № 1, p. $24-26,2007$.

6. Minh, N. Q., Ceramic Fuel Cells. J. Am. Ceram. Soc., v. 76, ํo 3, p. $563-588,1993$.

7. Ormerod, R. M., Solid oxide fuel cells. Chem. Soc. Rev., v. 32, p. 17-28, 2003.

8. Yamamoto, O., Solid oxide fuel cells: Fundamental aspects and prospects. Electrochem. Acta., v. 45, p. 2423-2435, 2000.

9. Alcaide, F., Cabot, P.L., Brilas, E., Review - Fuel cells for chemicals and energy cogeneration. J. Power Sources, v. 153, p. 46-60, 2006.

10. Onovwiona, H.I., Ugursal, V.I., Residential cogeneration systems: review of the current technology. Renew. and Sust. Energy Rev., v. 10, p. $389-431,2006$.

11. Tu, Hengyong, T., Stimming, U., Advances, aging mechanisms and lifetime in solid-oxide fuel cells. J. Power Sources, v.127, p. 284-293, 2004.

12. Stambouli, A. B., Traversa, E. Solid oxide fuel cells (SOFCs): a review of an environmentally clean and efficient source of energy. Renew. and Sust. Energy Rev., p. 433-455, 2002. 
13. Minh, N. Q.; Solid oxide fuel cell technology - features and applications. Solid State Ionics, v. 174, p. 271 - 277, 2004.

14. Reitz, T. L., Xiao, H., Characterization of electrolyte-electrode interlayers in thin film solid oxide fuel cells. J. Power Sources, v. 161, p. $437-443$, 2006.

15. Hawkes, A.D., Aguiar, P., Croxford, B., Leach, M.A., Adjiman, C.S., Brandon, N.P., Solid oxide fuel cell micro combined heat and power system operation strategy: Options for provision of residential space and water heating. J. Power Sources, v. 164, p. 260 -271, 2007.

16. Jensen, K.V. The Ni-YSZ interface, Structure, composition and electrochemical properties at $1000{ }^{\circ} \mathrm{C}$. Riso National Laboratory, Roskilde, Denmark, Thesis June 2002.

17. Bangwu Liu, Yue Zyang. Status and prospects of intermediate temperature solid oxide fuel cells - J. University of Sci Tec Beijing, Vol 18, ni, p. 8490, 2008.

18. Stöver, D., Buchkremer, H.P., Uhlenbruck, S., Processing and properties of the ceramic conductive multilayer device solid oxide fuel cell (SOFC). Ceram. Int., v. 30, p. 1107 - 1113, 2004.

19. Basu, R.N., Blass, G., Buchkremer, H.P., Stover, D. Simplified processing of anode-supported thin film planar solid oxide fuel cells. J. Eur. Ceram. Soc., v. 25, p. $463-471,2005$.

20. Kakaç, S., Pramuanjaroenkij, A., Zhou, X.Y., A Review of numerical modeling of solid oxide fuel cell. Int. J. Hydrogen Energy, v. 32, p. 761 - 786, 2006.

21. Kim, S.D., Hyun, S.H., Moon, J., Kim, J.H., Song, R.H., Fabrication and characterization of anode-supported electrolyte thin films for intermediate temperature solid oxide fuel cells. J. Power Sources, v. 139, p. $67-72$, 2005.

22. Haile, S. M., Fuel cell materials and components, Acta Mat., v. 51, p. $5981-6000,2003$.

23. Charpentier, P., Fragnaud, P., Schleich, D.M., Gehain, E., Preparation of thin film SOFCs working at reduced temperature. Solid State lonics, v. 135 , p. $373-380,2000$. 
24. Xin, X., Lu, Z., Huang, X., Sha, X. Zhang, Y., Su, W., Anode-supported solid oxide fuel cell basedon dense electrolyte membrana fabricated by filter-coating. J. Power Sources, v. 159, p. 1158 - 1161, 2006.

25. Jiang, S.P., Chan, S.H. A review of anode materials development in solid oxide fuel cells. J. Mater. Sci., v. 39, p. $4405-4439,2004$.

26. Li, S., Guo, R., Li, J., Chen, Y. Liu, W. Synthesis of $\mathrm{NiO}-\mathrm{ZrO}_{2}$ powders for solid oxide fuel cells. Ceram. Int., v. 29, p. 883-886, 2003.

27. Kim, S., Lee, W., Lee, W., Park, S.D., Song, J.S., Lee, E.G. Preparation of nanocrystalline nickel oxide-yttria-stabilized zirconia composite powder by solution combustion with ignition of glycine fuel. J. Mater. Res., v.16, no 12, p. 3621 - 3627, 2001.

28. Tamburini, U.A., Chiodelli, G., Arimondi, M., Maglia, F., Spinolo, G., Munir, Z.A., Electrical properties of $\mathrm{Ni} / \mathrm{YSZ}$ cermets obtained through combustion synthesis. Solid State Ionics, v. 110 p. $35-43,1998$.

29. Hackley, V. A. Colloidal processing of silicon nitride with poly(acrylic acid): I, Adsorption and electrostatic interactions. J. Am. Ceram. Soc., v. 80, ํㅜ 9, p. 2315-2325, 1997.

30. Oliveira, I.R., Studart, A. R., Pileggi, R.G., Pandolfelli, V.C., Dispersão e empacotamento de partículas, princípios e aplicações em processamento cerâmico, Fazendo Arte Editorial, (2000)

31. Zhu, W.Z. and Deevi, S.C. A review on the status of anode materials for solid oxid fuel cells. Mater. Sci.Eng. A, v. 362, p. 228 - 239, 2003.

32. Mori, H., Wen, C., Otomo, J., Eguchi, K., Takahashi, H. Investigation of the interaction between $\mathrm{NiO}$ and yttria-stabilized zirconia (YSZ) in the $\mathrm{NiO} / \mathrm{YSZ}$ composite by temperature-programmed reduction technique. Appl. Catal. A: General. v. 245, p. 79-85, 2003.

33. Stevens, R. Zirconia and zirconia ceramics - London UK.: Magnesium Elektron Ltd., 1986.

34. Subbarao, E.C., Zirconia - an overview In: A. H. Heuer, L. W. Hobbs (Eds), Advances in ceramics v. 3: Science and technology of zirconia I, Columbus, Oh: The american Ceramic Society, 1981 p. 1.

35. Cahn, R. W. Haasen, P. Kramer, E.: Materials Science and Tecnology a comprehensive treatment. Structure and properties of ceramics. V 11, 1994. 
36. Hannink, R. H. J., Kelly, P. M., Muddle, B. C., Transformation toughening in zirconia - containing ceramics. J. Am. Ceram. Soc., v. 83, p. 461-487, 2000.

37. Park, Y. M., Choi, G. M., Microstructure and electrical properties of YSZ-NiO composites. Solid State Ionic v.120, p. 265-274, 1999.

38. Tietz, F., Dias, F. J., Simwonis, D., Stover, D., Evaluation of commercial nickel oxide powders for components in solid oxide fuel cells. J. Eur. Ceram. Soc., v. 20, p. 1023-1034, 2000.

39. EG \& Services. Fuels cells handbook. US Department of Energy, Morgantown, 2000.

40. Akinc, M., Jongen, N., Lemaitre, J. and Hofmann, H. Synthesis of nickel hydroxide powders by urea decomposition. J. Eur. Ceram. Soc., v. 38, p. 1559-1564, 1998.

41. Abraham, I., \& Gritzner, G. J., Powder preparation, mechanical and electrical properties of cubic zirconia ceramics. J. Eur. Ceram. Soc., v. 16, p. 71-77, 1996.

42. Lazar, D.R.R. Avaliação da influência de elementos de terras raras pesadas na microestrutura e nas propriedades mecânicas e elétricas de cerâmicas de zircônia-ítria 2002. Tese (doutoramento)- Instituto de Pesquisas Energéticas e Nucleares, São Paulo.

43. Piticescu, R. R., Monty, C., Taloi, D., Motoc. A., and Axinte, S. Hydrothermal synthesis of zirconia nanomaterials. J. Eur. Ceram. Soc., v. 21, p. 2057-2060, 2001.

44. G. D. and Mascolo, G., Hydrothermal synthesis of $\mathrm{ZrO}_{2}-\mathrm{Y}_{2} \mathrm{O}_{3}$ solid solutions at low temperature. J. Eur. Ceram. Soc., v. 20, p. 139-145, 2000.

45. Juárez, R. E., Lamas, D. G., Lascalea, G. E., N.E. and Reca,N. E. W., Synthesis of nanocrystalline zirconia powders for TZP ceramics by a nitrate-citrate combustion route. J. Eur. Ceram. Soc., v. 20, p. 133-138, 2000.

46. Venkatachari, K. R., Huang, D., Steven P. Ostrander, S. P. and Schulze, W. A., A combustion synthesis process for synthesizing nanocrystalline zirconia powders. J. Mat. Res., v. 10, n³, p. 748-761, 1995. 
47. Robert, C. L., Ansart, F., Castilho, S. and Richard, G. Synthesis of YSZ powders by sol-gel method: surfactant effects on the morphology. Solid State Sci., v. 4, p. 1053-1059, 2002.

48. Okubo, T., Nagamoto, H., Low temperature preparation of nanostructured zirconia and YSZ by sol-gel processing. J. Mat. Sci., v. 30, p. $749-757$, 1995.

49. Subbaiah, T, Mohapatra, R., Mallick, S., Misra, K. G., Singh, P. and R.P. Das, R. P. Characterisation of nickel hydroxide precipitated from solutions containing $\mathrm{Ni}^{2+}$ complexing agents. Hydrometallurgy, v. 68, p. 151-157, 2003.

50. Jayashree, R. S. and P. Vishnu Kaimath, P. V. Nickel hydroxide electrodeposition from nickel nitrate solutions: mechanistic studies. J. Power Sources, v. 93, p. 273-278, 2001.

51. Zhang, Y., Zhou, Z. and Yan, J., Electrochemical behaviour of $\mathrm{Ni}(\mathrm{OH})_{2}$ ultrafine powder. J. Power Sources, v. 75, p. 283-287, 1998.

52. Song, Q., Zhiyuan Tang, Z., Guo, H., Chan, S. L. I., Structural characteristics of nickel hydroxide synthesized by a chemical precipitation route under different pH values. J. Power Sources, v. 112, p. 428-434, 2002.

53. Yang, C.C., Synthesis and characterization of active materials of $\mathrm{Ni}(\mathrm{OH})_{2}$. Int. J. Hydrogen Energy, v. 27, p. 1071 - 1081, 2002.

54. Keklikian, L. D., Haq, I. and Matijevic, E., Preparation and characterization of well-defined colloidal nickel compounds. Colloids and Surf. A: Physicochem. and Eng. Aspects, v. 92, p. 267-275, 1994.

55. Sato, K., Okamoto, G., Naito, M., Abe, H., NiO/YSZ nanocomposite particles synthesized via co-precipitation method forelectrochemically active Ni/YSZ anode, J. Power Source, v. 193, p. 185-188, 2009.

56. Zhong, S., Hepworth, M.T., A calculation method for determining equilibria in metal-ammonia-water systems. Hydrometallurgy, v. 38, p. 15-37, 1995.

57. Grgicak, C.M., Green, R.G., Du, W.F., Giorgi, J.B., Synthesis and characterization of NiO-YSZ anode materials: Precipitation, calcination, and effects on sintering. J. Am. Ceram. Soc., v. 88, 2007n ${ }^{\circ} 11$, p. $3081-3087,2005$. 
58. J.D. Lee, J.D., Química Inorgânica, Tradução da $3^{\text {a }}$ edição inglesa, Ed. Edgard Blücher, 1980.

59. Li, Y., Xie, Y., Gong, J., Chen, Y., Zhang, Z., Preparation of Ni/YSZ materials for SOFC anodes by buffer-solution method. Mater. Sci. Eng. B, v. 86, p. $119-122,2001$.

60. Li, S., Guo, R., Li, J., Chen, Y. Liu, W. Synthesis of $\mathrm{NiO}-\mathrm{ZrO}_{2}$ powders for solid oxide fuel cells. Ceram. Int., v. 29, p. 883-886, 2003.

61. Marinsek, M., Zupan, K., Maeek, J., Ni-YSZ cermet anodes prepared by citrate/nitrate combustion synthesis. J. Power Sources, v. 106, p. $178-188,2002$.

62. Moon, J.W., Lee, H.L., Kim, J.D., Kim, G.D., Lee, D.A., Lee, H.W., Preparation of $\mathrm{ZrO}_{2}$-coated $\mathrm{NiO}$ powder using surface-induced coating. Mater. Letters, v. 38, p. 214 - 220, 1999.

63. Robert J. Hunter, Zeta Potential in Colloid Science, Principles and Applications, Academic Press (1981).

64. Shojai, F., Pettersson, A. B. A., Mantyla, T., Rosenholm, J. B., Electrostatic and eletrosteric stabilization of aqueous slips of $3 \mathrm{Y}-\mathrm{ZrO}_{2}$ powder. J. Eur. Ceram. Soc., v. 20, p. $277-283,2000$.

65. Xiang, L., Deng, X. Y., Jin, Y., Experimental study on synthesis of $\mathrm{NiO}$ nano- particles, Scripta Mater., v. 47, p. 219-224, 2002.

66. Wang, J., Gao, L., Surface and electrokinetic properties of Y-TZP suspensions stabilized by polyelectrolytes. Ceram. Inter., p. 187-191, 2000.

67. Zhang, Y., Huang, X., Lu, Z., Liu, Z., Ge, X., Xu, J., Xin, X., Sha, X., Su, W., A study of the process parameters for yttria-stabilized zirconia electrolyte films prepared by screen-printing. J. Power Sources, v. 160, p. 1065-1073, 2006.

68. Jia, L., Lu, Z., Miao, J., Zhiguo Liu, Z. Jia, L., Su, W., Effects of precalcined YSZ powders at different temperatures on Ni-YSZ anodes for SOFC. J. Alloy Compd., v. 414, p. 152 - 157, 2006.

69. Yu, J.H., Park, G.W., Lee, S., Sang Kuk Woo, S.K., Microstructural effects on the electrical and mechanical properties of Ni-YSZ cermet for SOFC anode. J.Power Sources, v. 163, p. 926 - 932, 2007. 
70. Madsen, L.G., Larsen, P.H., Bonanos, N., Engell, J., Linderoth, S., Mechanical strength and electrical conductivity of Ni-YSZ cermets fabricated by viscous processing. J. Mater. Sci, v. 141, p.1097 - 1107, 2006.

71. Patil, K.C., Aruna, S.T. Mimani, T., Combustion synthesis: an update. Current Opinion in Solid State and Mater. Sci., v. 6, ํo 6, p. $507-512$, 2002.

72. Patil, K.C., Aruna, S.T., Ekambaram, S., Combustion synthesis, Current Opinion in Solid State and Mater. Sci., v. 2, p. 158 - 165, 1997.

73. Mukasyan, A.S., Epstein, P., Dinka, P., Solution combustion synthesis of nanomaterials. Proc Combustion Inst., v. 31, p. 1789 - 1795, 2007.

74. Mckittrick, J., Shea, L.E., Bacalski, C.F., Bosze, E.J., The influence of processing parameters on luminescent oxides produced by combustion synthesis. Displays, v.19 p. $169-172,1999$.

75. Shea, L.E., Mckittrick, J., Lopez, O.A., Synthesis of red-emitting, small particle size luminescent oxides using an optimized combustion process. J. Am. Ceram. Soc., v. 79, № 12, p. 3257 - 3265, 1996.

76. Fumo, D.A., Jurado, J.R., Segadães, A.M., Frade, J.R., Combustion synthesis of iron-substituted strontium titanate perovskites. Mater. Res. Bull., v. 32, oㅡ 10, p. 1459 - 1470, 1997.

77. Ringuede, A., Labrincha,J. A., Frade, J. R., A combustion synthesis method to obtain alternative cermet materials for SOFC anodes. Solid State lonics, v. 141 - 142, p. 549-557, 2001.

78. Priyatham, Baur, R., Synthesis and characterization of nanocrystalline Ni-YSZ cermet anode for SOFC, Mat. Charac, v. 61, p.54-58, 2010.

79. Liang, M., Yu, B., Wen, M., Chen, J., Xu, J., Zhai, Y., Preparation of NiO-YSZ composite powder by a combustion method and its application for cathode of SOEC, Inter. J. Hydrogen Energy, v.35, p. 2852-2857, 2010.

80. Marinsek, M., Zupan, K., Microstructure evaluation of sintered combustionderived fine powder NiO-YSZ, Ceram. Int., v.36, p. 1075-1082, 2010.

81. Aruna, S. T., Muthuraman, M. and Patil, K. C., Synthesis and properties of Ni-YSZ cermet: anode material for solid oxide fuel cells. Solid States Ionics, v. 111, p. 45-51, 1998. 
82. Kim, S. J., Lee, W., Lee, W. J., Park, S. D., Song, J. S. and E Lee, E. G., Preparation of nanocrystalline nickel oxide-yttria stabilized zirconia composite powder by solution combustion with ignition of glycine fuel. J. Mater. Res., v. 16, o 12, p. 3621-3627, 2001.

83. Shih, F.Y., Fung, K.Z., Lin, H.C., Chen, G.J., Low-temperature synthesis of nanocrystalline NiO-YSZ powders by succinic acid-assisted combustion, J. Power Sources, v. 160, p. 148-154, 2006

84. Mohebbi, H., Ebadzadeh, T., Hesari, F.A., Synthesis of nano-crystalline NiO-YSZ by microwave-assisted combustion synthesis, Powder Technol., v. 188, p.183-186, 2009

85. Mohebbi, H., Ebadzadeh, T., Hesari, Synthesis of nanocomposite nickel oxide/yttrium-stabilized zirconia (NiO/YSZ) powders for anodes of solid oxide fuel cells (SOFCs) via microwave-assisted complex-gel autocombustion, J. Power Sources, v. 178, p. 64-68, 2008.

86. James $S$ Reed, Principles of ceramics processing, Second Edition, A Wiley - Interscience Publication

87. Marinsek, M., Zupan, K., Maeek, J., Preparation of Ni-YSZ composite materials for solid oxide fuel cell anodes by the gel, J. Power Sources, v. 86, p. $383-389,2000$

88. Restivo, T.A.G., Redução carbotérmica de óxidos de urânio assistida por banho solvente, 2003. 106 p. Tese (Doutorado em Doutorado em Engenharia Química) - Escola Politécnica da Universidade de São Paulo, POLI/USP, Brasil.

89. Yan, R.; Chu, F.; Ma, Q.; Liu, X.; Meng, G., Sintering kinetics of samarium doped ceria with addition of cobalt oxide, Mater. Lett., 60, p.3605-3609, 2006

90. Duran, P., Tartaj, J., Capel, F., Moure, C., Processing and characterisation of a fine nickel oxide/zirconia/composite prepared by polymeric complex solution synthesis. J. Eur.Ceram. Soc., v. 23, p. 2125-2133, 2003.

91. Clemmer, R. M. C., Corbin, S. F., Influence of porous composite microstructure on the processing and properties of solid oxide fuel cell anodes. Solid State lonics, v. 166, p. 251-259, 2004. 
92. Grgicak, C.M., Green R. G., Giorgi, J.B., Control of microstructure, sinteribility and performance in co-preciptated NiYSZ, Cu YSZ and CoYSZ SOFC anodes J. Mat. Chem., v.16, p. 885-897, 2006.

93. Park, Y.M., Choi, G.M., Microstructure and electrical properties of YSZ-NiO Composites. Solid State lonics, v.120, p. 265-274, 1999.

94. Fukui, T., Ohara, S., Naito, M., Nogi, K., Performance and stability of SOFC anode fabricated from NiO-YSZ composite particles. J. Power Sources, v. 110, p. 91-95, 2002

95. Kondo, H., Sekino, T., Kusunose, T., Nakayama, T., Yamamoto, Y., Niihara, K., Phase stability and electrical property of NiO-doped yttriastabilized zirconia. Mater. Letters, v. 57, p. 1624-1628, 2003.

96. Park, Y. M., Choi, G. M., Mixed ionic and electronic conduction in YSZNiO composite. J. Electrochem. Soc., v. 14, oㅜ 3, p. $883-889,1999$.

97. Lee, J. H., Moon, H., Lee, H. W., Kim, W. J., Kim, J. D., Yoon, K. H., Quantitative analysis of microstructure and its related electrical property of SOFC anode, Ni-YSZ cermet. Solid State Ionics, v.148, p. 15 - 26, 2002.

98. Lee, C. H., Lee, C. H., Lee, H. Y., Oh, S. M., Microstructure and anodic properties of Ni/YSZ cermets in solid oxide fuel cells. Solid State lonics, v. 98, p. $39-48,1997$.

99. Faes, A., Nakajo, A., Wyser, A.H., Dubois, D., Redox study of anodesupported solid oxide fuel cell, J. Power Sources, v.193, p. 55 - 64, 2009.

100. Radovic, M., Curzio, E.L., Mechanical properties of tape cast nickel-based anode materials for solid oxide fuel cells before and after reduction in hydrogen, Acta Mater.., v. 52, p. 5747 - 5756, 2004.

101. Wang, Y., Walter, M.E., Sabolsky, K., Scabaugh, M.M., Effects of powder sizes and reduction parameters on the strength o Ni-YSZ anodes, Solid State lonics, v. 177, p.1517 - 1527, 2006.

102. Rojas, A.R., Esparaza-Ponce, H.E., Fuents, L. In situ X-ray Rietveld analysis of Ni-YSZ solid oxide fuel cell anodes during $\mathrm{NiO}$ reduction in $\mathrm{H}_{2}$.

J. Phys. D: Appl. Phys., v. 38, p. 2276 - 2282, 2005.

103. Jeangros,Q., Faes,A., Wagner, J.B., Hansen, T.W., Aschauer, U., Van herle, J., Wyser, A,H., Borkowski, R.E.D., In situ redox cycle of a nickelYSZ fuel cell anode in an environmental transmission electron microscope, Acta Mater., v. 58, p. 4578 - 4589, 2010. 
104. Borer, A. L., Bronnimann, C., Prins, R., $\mathrm{ZrO}_{2}-$ Promoted $\mathrm{Rh} / \mathrm{SiO}_{2}$ Catalysts in CO Hydrogenantion and Temperature - Programmed Reduction. J. Catal., v. 145, p. 516 - 52, 1994.

105. Guglielminotti, E., Giamello, E., Pinna, F., Strukul, G., Martinengo, S., Zanderighi, L., Elemntary steps in Co hydrogenation on Rh catalysts

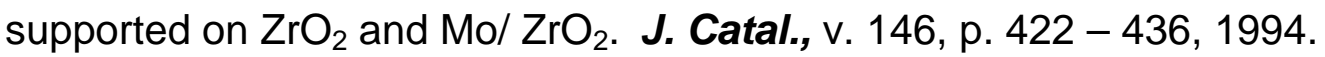

106. Dow, W. P., Wang, Y. P., Huang, T. J., Yttria-stabilized zirconia supported copper oxide catalyst. J. Catal., v.160, p. 155-170, 1996.

107. Radovic, M., Lara-Curzio, E., Mechanical properties of tape cast nickelbased anode materials for solid oxide fuel cells before and after reduction in hydrogen. Acta Mater., v. 52, p. 5747 - 5726, 2004.

108. David Waldbilig, D., Wood, A., Ivey, D.G., Thermal analysis of cyclic reduction and oxidation behaviour of SOFC anodes. Solid State lonics, v. 176, p. $847-859,2005$.

109. Rodrigues, J. A., Hanson, J. C., Frenkel, A. I., Kim, J. Y., Perez, M., Experimental and theoretical studies on the reaction of $\mathrm{H}_{2}$ with NiO: Role of $O$ vacancies and mechanism for oxide reduction. J. Am. Chem. Soc., v. 124, no 2, p. $346-354,2002$.

110. Haslam, J.J., Pham,A.Q., Chung, B.W., Dicarlo, J.F., Glass, Effects Effects of the Use of Pore Formers on Performance of an Anode Supported Solid Oxide Fuel Cell, J. Am. Ceram. Soc., v.88, p. 513-518. 2005.

111. Jain, S.R., Adiga, K.C., Verneker, P.V., A new approach to thermochemical calculations of condensed fuel-oxidizer mixtures, Combustion and Flame, v. 40, p. $71-79,1981$.

112. Hurst, N.W., Gentry, S.J., Jones, A., McNicol, Temperature programmed reduction, Catal. Rev. Sci. Eng., v. 24, p. 233 - 309, 1982.

113. Richardson, J.T., Scates, R., Twigg, M.V., X-ray diffraction study of nickel oxide reduction by hydrogen Appl. Catal., A: General, v. 246, p. $137-150,2003$.

114. Ramanathan, S., Krishnakumar, K.P., Banerjee, P.K.S., Powder dispersion and aqueous tape casting of YSZ-NiO composite. $J$. Mater.Sci., v. 39, p. $3339-3344,2004$. 
115. Han, K.R., Jung, Y., Lee, H., Kim, C.S., Fabrication of NiO/YSZ anode material for SOFC via mixed $\mathrm{NiO}$ precursors. Mat. Letters, v. 61, p. 1242 - 1245, 2007.

116. Fouquet, D., Muller, A.C., Weber, A., Ivers-Tiffee, Kinetics of oxidation and reduction of Ni-YSZ cermets, lonics, v.8, p. 103-108, 2003.

117. Biamino, S., Badini, C., combustion synthesis of lanthanum chromite starting from water solutions: Investigation of process mechanism by DTA - TGA - MS. J. Eur. Ceram. Soc., v. 24, p. 3021 - 3034, 2004.

118. Chavan, S.V., Pillai, K.T., Tyagi, A.K., Combustion synthesis of nanocrystalline yttria: Tailoring of powder properties. Mater. Sci. Eng. B, v. 132 , p. $266-271,2006$

119. Biamino, S., Fino, P., Pavese, M., Badini,C., Alumina-zirconia-yttria nanocomposites prepared by solution combustion synthesis. Ceram. Inter., v. 32, p. $509-513,2006$.

120. Pihlatie M., Kaiser, A., Mogensen, M., Redox stability of SOFC: Thermal analysis of Ni-YSZ composites, Solid State Ionics, v.180, p. 1100-1112, 2009.

121. Modena, S., Ceschini, S., Tomasi, A., Reduction and reoxidation processes of NiO-YSZ composite for Solid Oxide fuel cell anodes, J. Fuel Cell Sci and Tech., V. 3, p.487-491 (2006).

122. Haslam, J. J.; Pham, A-Q.; Chung, B. W.; DiCarlo, J. F.; Glass, R. S.; Effects of the Use of Pore Formers on Performance of an AnodeSupported Solid Oxide Fuel Cell, J. Am. Ceram. Soc., 88 [3], p. 513-518, 2005. 